UNIVERSIDADE DE SÃo PAULO

FACULDADE DE Filosofia, LETRAS E CIÊNCIAS Humanas

Programa DE PÓs-GraduAÇão EM HistóRIA SOCIAL

DEPARTAMENTO DE HISTÓRIA

SHEILA VIRGINIA ROCHA DE OLIVEIRA CASTRO

Representações da Independência na literatura brasileira, séculos XIX-XXI

(versão corrigida) 


\author{
UNIVERSIDADE DE SÃO PAULO \\ FACULDADE DE Filosofia, LETRAS E CIÊNCIAS Humanas \\ Programa DE PÓs-GraduAÇão EM HistóRIA SOCIAL \\ DEPARTAMENTO DE HISTÓRIA
}

SHEILA VIRGINIA ROCHA DE OLIVEIRA CASTRO

\title{
Representações da Independência na literatura brasileira, séculos XIX-XXI
}

(versão corrigida)

\begin{abstract}
Dissertação de Mestrado apresentada ao Programa de PósGraduação em História Social do Departamento de História da Faculdade de Filosofia, Letras e Ciências Humanas da Universidade de São Paulo, para obtenção do título de Mestre em História Social.
\end{abstract}

Orientador: Prof. Dr. João Paulo Garrido Pimenta

São Paulo

2019 
Autorizo a reprodução e divulgação total ou parcial deste trabalho, por qualquer meio convencional ou eletrônico, para fins de estudo e pesquisa, desde que citada a fonte.

Catalogação na Publicação

Serviço de Biblioteca e Documentação

Faculdade de Filosofia, Letras e Ciências Humanas da Universidade de São Paulo

Castro, Sheila Virginia Rocha de Oliveira Castro
C355r Representações da Independência na literatura brasileira, séculos XIX-XXI / Sheila Virginia Rocha de Oliveira Castro Castro; orientador João Paulo Garrido Pimenta Pimenta. - São Paulo, 2019. $158 \mathrm{f}$.

Dissertação (Mestrado) - Faculdade de Filosofia, Letras e Ciências Humanas da Universidade de São Paulo. Departamento de História. Área de concentração: História Social.

1. Independência do Brasil. 2. Representações. 3. Literatura Brasileira. 4. Cultura de História. I. Pimenta, João Paulo Garrido Pimenta, orient. II. Título. 
fflCh UNIVERSIDADE DE SÃO PAULO

FACULDADE DE FILOSOFIA, LETRAS E CIÊNCIAS HUMANAS

ENTREGA DO EXEMPLAR CORRIGIDO DA DISSERTAÇÃO/TESE

Termo de Ciência e Concordância do (a) orientador (a)

Nome do (a) aluno (a): Sheila Virginia Rocha de O. Castlo

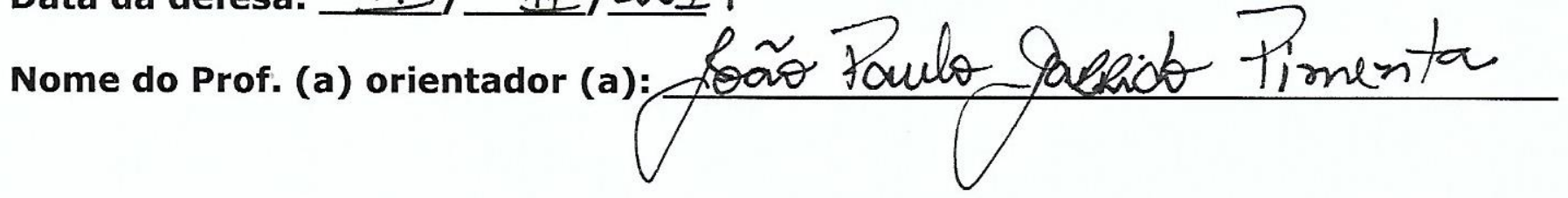

Nos termos da legislação vigente, declaro ESTAR CIENTE do conteúdo deste EXEMPLAR CORRIGIDO elaborado em atenção às sugestões dos membros da comissão Julgadora na sessão de defesa do trabalho, manifestando-me plenamente favorável ao seu encaminhamento e publicação no Portal Digital de Teses da USP.

São Paulo, 11, 01, 2020

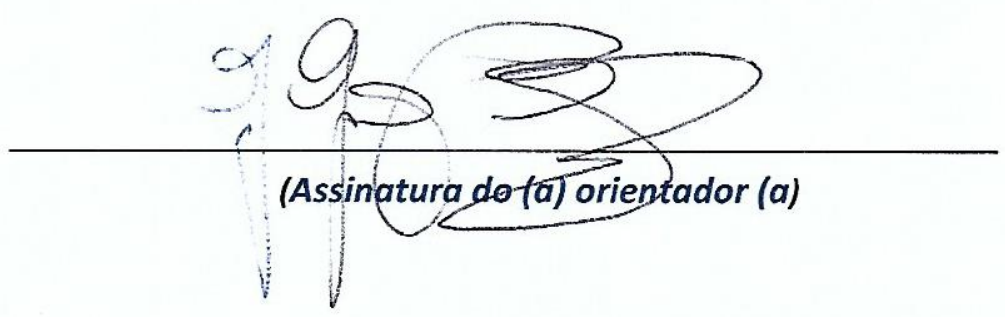




\title{
RESUMO
}

Nesta pesquisa são analisadas representações da Independência na literatura brasileira entre os séculos XIX e XXI, a partir da noção de cultura de história como linha condutora, isto é, as formas com que uma sociedade se relaciona, de maneira abrangente, com sua história, contemplando perspectivas, posturas e valores diversos. Utilizando como categoria de análise a representação, e examinando aspectos políticos, econômicos, sociais e culturais do período - assim como seus personagens -, pretende-se verificar e entender como a Independência do Brasil é representada na literatura brasileira. O recorte cronológico propõe uma investigação de longa duração com o objetivo de perceber possíveis reafirmações e/ou transformações dessas representações ao longo do tempo. Para tanto, foram selecionadas obras literárias de gêneros variados que alcancem leitores diversificados.

Palavras-chave: Cultura de história; Independência do Brasil; Representações; Literatura Brasileira

\begin{abstract}
This research analyzes representations of the Brazilian Independence process in its national literature between the XIX and XXI centuries, considering the Culture of History notion. In general, this corresponds to the ways in which a society relates to its own History, encompassing different views, attitudes and values. Considering as category for analysis the representation, and examining as well the political, economic, social and cultural aspects of the period - and its characters -, we intend to verify and understand how the Independence of Brazil is represented in the Brazilian literature. The chronological cut proposes a long-term investigation in order to realize possible reaffirmations and/or transformations of these representations over time. To this end, literary works of various genres that reach diverse readers were selected.
\end{abstract}

Keywords: Culture of History; Independence of Brazil; Representations; Brazilian Literature 


\section{AGRADECIMENTOS}

À CAPES - Coordenação de Aperfeiçoamento de Pessoal de Nível Superior, pela concessão da bolsa de mestrado para financiamento desta pesquisa, o que foi essencial para sua realização.

Ao meu orientador, o professor João Paulo Garrido Pimenta, pela oportunidade e cuidadosa orientação desta pesquisa, pelo estímulo e confiança aceitando a proposta para trabalhar com história e literatura, além de todo apoio para realização desse trabalho.

Ao professor Júlio César Pimentel pelo apoio, pelo fecundo diálogo e valiosas sugestões, além da recepção sempre solícita. A participação (e acolhida) no grupo de pesquisa "História \& Literatura" se tornou indispensável para a realização desta pesquisa e de minha jornada, além de promover um estimulante ambiente de debates e trocas.

Ao professor Tâmis Peixoto Parron pelas sugestões, tanto sobre os caminhos a seguir quanto pela indicação de obras a incorporar nesta pesquisa.

Aos professores João Adolfo Hansen e Ricardo Carvalho, cujas disciplinas que cursei auxiliaram no entendimento da relação entre história e literatura, e dialogaram de forma direta com minha investigação.

Ao Lab-Mundi (Laboratório de Estudos sobre o Brasil e Sistema Mundial), que promove um ambiente fecundo de estudos e debates, e a todos os colegas pela leitura de meu relatório de qualificação. Agradeço especialmente a Ana Prates, Marcelo Ferraro, Marco Aurélio dos Santos, Mariana F. Paulino, José Evando de Melo, Pedro Sette (que, generosamente me concedeu um exemplar de um dos romances aqui analisados), Priscila Ferrer, Rafael Fanni, Sarah Tortora Boscov, e ao professor Rafael Marquese.

Aos amigos - vocês são essenciais em minha vida - obrigada por todo o suporte e carinho, acolhida, cervejas, desabafos, leituras, críticas e sugestões, puxões de orelha, risadas e bagunças, enfim por toda a parceria: Fernando Dizzio, Luís Otávio Vieira, Clarissa Silvestre, Thomáz Fortunato, Letícia Tarifa, Vinícius Bisterço, Michelly Cristina, Fernanda Prado, Buca, Carolina Luiz, Ana Carolina Silva, Thiago Arnoult, Rafael Vaz, Tatiane Lima, Fernanda Oda e Thaísa Buzzi. E também a tantos outros amigos queridos que embora não aqui nomeados fizeram e fazem parte dessa jornada.

À minha família, cujo apoio foi indispensável para minha formação e para que conseguisse chegar até esse momento, concluindo este trabalho: ao meu pai, Nelson; à 
minha mãe, Hortênsia, ao meu irmão Tuco, e minhas irmãs Bel e Iris. Amo demais todos vocês e o suporte que me proporcionam é fundamental!

Finalmente, às minhas maiores companheiras: Rayla e Jade (devoradora - literal de Memórias Póstumas de Machado de Assis). As monstrinhas peludas mais amorosas e amadas que existem, adentraram em minha (nossas) vida(s) no ano que ingressei no mestrado. Fonte de afeto, alegria e refúgio infinito, me acompanham em todos os momentos. 


\section{SUMÁRIO}

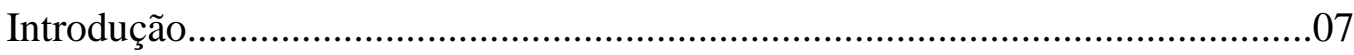

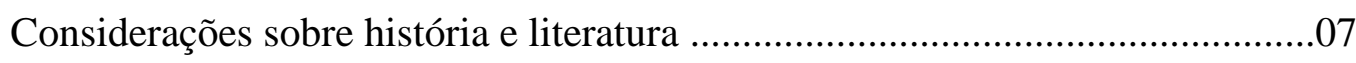

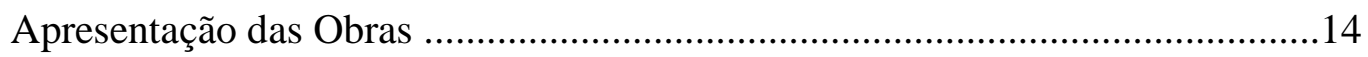

Capítulo 1. A Independência na literatura brasileira..............................................33

1.1 Linhas gerais de desenvolvimento e interpretação da Independência.............33

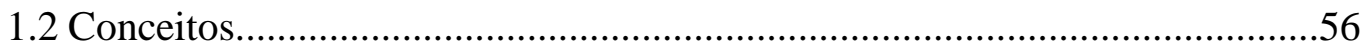

Capítulo 2. Personagens da Independência na literatura..................................91

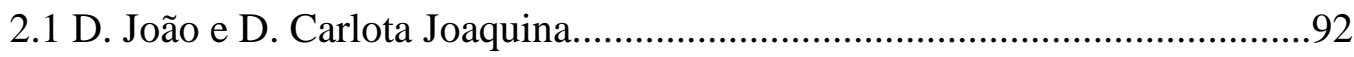

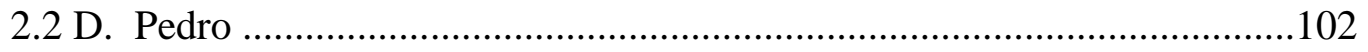

2.3 Personagens femininas: Imperatriz Leopoldina, D. Amélia e Domitila de

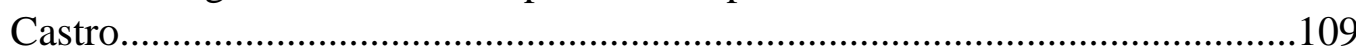

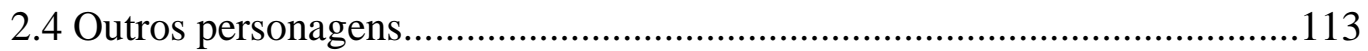

2.5 Personagens Fictícios: A desconstrução do mito de heróis em Viva o Povo

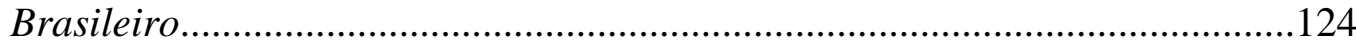

Capítulo 3. O Brasil e os brasileiros: Imagens de um caleidoscópio................131

3.1 Identidades políticas no Brasil do século XIX..........................................131

3.2 Imagens dos brasileiros: estereótipos de longa duração.............................135

3.3 Costumes: ritos e celebrações populares..................................................139

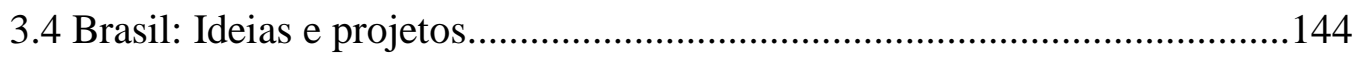

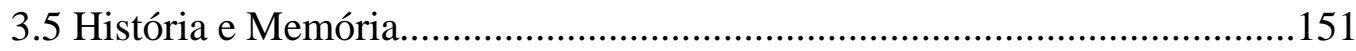

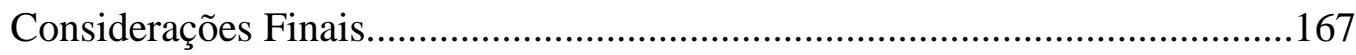

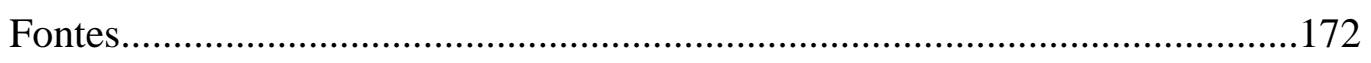

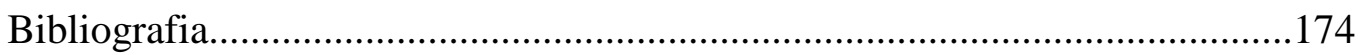




\section{INTRODUÇÃO}

\section{Considerações sobre história e literatura}

Há um debate clássico acerca da escrita da história e da literatura: durante muito tempo não houve uma divisão estrita entre as duas disciplinas, utilizava-se a noção de "belas-letras" que compreendia "tudo o que a retórica e a poética podiam produzir, não

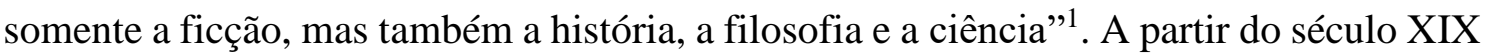
inicia-se um processo de separação entre História e Literatura, a partir da qual as escritas e narrativas de ambas passaram a ser tratadas de formas distintas com intuito de demarcar as diferenças de composição, análises e metodologias. Entretanto, como ocorrem as interações entre história e literatura? Para alguns pesquisadores da área de Letras, utilizar a literatura como objeto de análise para pesquisas em História pode parecer incoerente, pois os aspectos mais marcantes das obras literárias se relacionam com a estética, a imaginação e a construção narrativa (trama, personagens e sua profundidade, como as vozes se manifestam nas obras, de que forma os recursos discursivos e linguísticos são empregados, etc.). Para alguns historiadores, normalmente obras literárias são analisadas com foco nas representações e abordagens da história nelas presentes, bem como sobre o momento de sua produção e publicação, ou seja, o que reflete do momento histórico. Também podem importar questões relativas ao autor e seu entorno, aspectos de sua vida e formação, e como esses fatores influenciaram na produção de tais obras. Trabalhar nessa linha fronteiriça, entre história e literatura, sempre levanta discussões a respeito de sua abordagem e sentido. Todavia, aqui não se pretende promover ou aprofundar o debate da virada linguística da década de $1970 .^{2}$

\footnotetext{
${ }^{1}$ Antoine COMPAGNON, O demônio da teoria: literatura e senso-comum. Cleonice Paes Barreto MOURÃO e Consuelo Fortes SANTIAGO (tradução). Belo Horizonte: Editora UFMG, 2010, p.31.

2 A partir da década de 1970 começaram a surgir questionamentos e proposições acerca da escrita da história, ou da narrativa, movimento que ficou conhecido como "virada linguística" ou "giro linguístico". Os questionamentos levantados ocorriam em torno da proposta de um exercício apontado como "ficcional ou imaginativo" no trabalho do historiador para reconstrução do passado, que ocorreria através do discurso ou narrativa. Essa proposta se tornou polêmica entre historiadores, sobretudo a partir da publicação do ensaio de Hayden White, "O fardo da história" em 1966, depois incorporado ao livro Trópicos do Discurso, e do livro Meta-história: a imaginação histórica do século XIX, em 1973, gerando intenso debate acerca do ofício do historiador; da filosofia, da teoria e da escrita da história. Alguns expoentes do debate foram Hayden White; Dominick Lacapra; Roger Chartier; Carlo Ginzburg; David Harlan; Jorn Rüsen, entre outros. Sobre a virada linguística ver: Diogo da Silva ROIZ, "A reconstituição do passado e o texto literário: a resposta dos historiadores à 'virada linguística'”. In: Diálogos, DHI/ PPH/ UEM, v.13, n.3, p.587- 624, 2009; Diogo César Nunes da SILVA, "A história entre dilemas e perspectivas: anotações sobre a "virada linguística" em Hayden White, Dominick LaCapra e David Harlan”. XIV Encontro Regional da AnpuhRio : Memória e Patrimônio. Rio de Janeiro, 19 a 23 de julho de 2010, Unirio; Jurandir MALERBA (org.),
} 
Entretanto, a literatura como importante elemento que compõe a cultura, através de aspectos miméticos, de verossimilhança, pode apresentar, refletir ou mesmo inserir ideias, concepções e mesmo debates sobre a história presentes na sociedade e nos estudos historiográficos. Para além disso, a literatura também é elemento relevante para aprendizado, como aponta Antonio Candido: "analisando-a, podemos distinguir pelo menos três faces: (1) ela é uma construção de objetos autônomos como estrutura e significado; (2) ela é uma forma de expressão, isto é, manifesta emoções e a visão do mundo dos indivíduos e dos grupos; (3) ela é uma forma de conhecimento, inclusive como incorporação difusa e inconsciente." 3

Nessa dissertação consideramos que obras literárias podem apresentar um olhar, uma representação da história a partir da qual os leitores farão a interpretação conforme o aporte de saberes e cultura que possuem. Torna-se relevante, dessa forma, o repertório de conhecimentos e experiências que os leitores dispõem e que influenciará na leitura e sentido que esta receberá, portanto, que condicionará o potencial de suas representações. Assim, é importante salientar que um mesmo leitor poderá realizar leituras diversas de uma mesma obra. Essa variação de leituras e possíveis interpretações por um mesmo sujeito ocorre porque seu conjunto de conhecimentos está em transformação constante ${ }^{4}$.

Tomando esse ponto de partida, de que a literatura é um importante componente cultural e de aprendizado de sociedades, e traçando como linha condutora da investigação uma cultura de história, o intuito dessa pesquisa é analisar as representações da Independência na literatura brasileira do século XIX ao XXI. Mas o que é uma cultura de história? Cultura de história são os modos com que uma sociedade se relaciona com sua história em múltiplos aspectos. De forma mais detalhada, pode ser entendida "como um conjunto de atitudes e valores que se expressam em noções, concepções, representações,

\footnotetext{
História \& Narrativa : A ciência e a arte da escrita histórica. Petrópolis, RJ: Vozes, 2016; Hayden WHITE, Meta- História: a imaginação histórica do século XIX, 2.ed., São Paulo: EDUSP, 1995; Hayden WHITE, Trópicos do Discurso: ensaios sobre a crítica da cultura, 2.ed., São Paulo: EDUSP, 2001.

${ }^{3}$ Antonio CANDIDO, "O Direito à Literatura". In: Vários escritos. São Paulo: Duas Cidades; Rio de Janeiro: Ouro sobre azul, , 1988, p.176. Antonio Candido entende a literatura como um sistema simbólico formado a partir da construção de uma tradição, modo diverso do que entendemos. Nessa pesquisa partimos de um pressuposto distinto, consideramos os aspectos de abertura das obras e entendemos a importância da interação com o público a partir das leituras. São os leitores que realizam interpretações e podem inferir sentidos diversos a partir de seu repertório.

${ }^{4}$ Umberto ECO, Obra Aberta: Forma e indeterminação nas poéticas contemporâneas. São Paulo: Perspectiva, 1968, p.40-41.
} 
conceptualizações, interdições e outras posturas, de uma determinada sociedade em relação ao seu passado que pode ser considerado coletivo" 5 .

Consideramos que essa formulação se aproxima muito da forma como Jorn Rüsen define "cultura histórica". O autor relaciona consciência histórica e memória com cultura histórica, e define tudo o que a contempla:

La cultura histórica contempla las diferentes estratégias de la investigación científico-académica, de la creación artística, de la lucha política por el poder, de la educación escolar y extraescolar, del ócio y de otros procedimientos de memoria histórica pública, como concreciones y expresiones de uma única potencia mental. De este modo, la 'cultura histórica' sintetiza la universidad, el museo, la escuela, la administración, los médios, y otras instituciones culturales como conjunto de lugares de la memoria colectiva, y integra las funciones de enseñanza, del entretenimento, de la legitimación, de la crítica, de la distracción, de la ilustración y de otras maneras de memorar, en la unidad global de la memoria histórica. ${ }^{6}$

Essa definição de Rüsen também é englobada na cultura de história: todos esses aparatos que abordam a história de um país e a memória coletiva ajudam a compor um imaginário social, que é constantemente alimentando por representações, interpretações e leituras da história. Assim, essa cultura de história está sempre em movimento, podendo ser alterada, transformada ou ressignificada ao longo do tempo. O ponto que diferencia a cultura histórica proposta por Rüsen, da cultura de história como proposta pelos autores ${ }^{7}$

\footnotetext{
${ }^{5}$ João Paulo Garrido PIMENTA; César ATTI; Sheila Virginia CASTRO; Nadiesda DIMAMBRO; Beatriz Duarte LANNA ; Marina PUPO; Luís Otávio VIEIRA. "A Independência e uma cultura de história no Brasil”. Almanack, Guarulhos, n.8, nov.2014, p.6. Este artigo foi fruto de uma pesquisa, da qual participamos, que analisou a relação atual da sociedade brasileira com a história, especificamente com a Independência do Brasil. Nele, trabalhamos preliminarmente com a noção de cultura de história, além de proceder à sondagem de opinião pública através de questionários e análise de fontes complementares. Para definições convergentes de cultura de história, vide: Jacques LE GOFF, História e memória. Campinas:EDUNICAMP, 1990, p.47-48; Ângela de Castro GOMES, Cultura Política e cultura histórica no Estado Novo. In: ABREU, Martha; Rachel SOIHET; Rebeca GONTIJO (Org.). Cultura Política e leituras do passado: historiografia e ensino de história. Rio de Janeiro: Civilização Brasileira, 2007, p.4363; e Ângela de Castro GOMES. Historia, historiografía y cultura política en Brasil: algunas reflexiones. Ayer v. 2, 2008, p.115-139.

${ }^{6}$ Jorn RÜSEN, Que es la cultura histórica?: Reflexiones sobre uma nueva manera de abordar la historia. Tradução: F. Sánchez COSTA; Ib SCHUMACHER. Tradução disponível no endereço eletrônico: http://www.culturahistorica.es/ruesen/cultura_historica.pdf. Texto original em: K. FÜSSMANN; Jorn RÜSEN (eds.): Historische Faszination. Geschichtskultur heute, 1994, p.3-26.

7 João Paulo PIMENTA [et.al.], op.cit., 2014.
} 
é que nesta, os silenciamentos e negações também são incluídos, pois indicam posturas conflitivas que uma sociedade pode ter com seu passado.

Rüsen define a cultura histórica como "la memoria histórica (ejercida en y por la consciencia historica), que se señala al sujeto uma orientación temporal a su práxis vital, en cuanto le oferece uma direccionalidad para la actuación y uma autocomprensión de sí mismo"8. E esclarece que a consciência histórica é tema para uma pesquisa à parte; porém, pensa fazer sentido caracterizar a recordação ("actividad memorativa") da consciência histórica como uma forma narrativa (como um "contar histórias") sendo característica da cultura histórica. Seria uma forma de trazer ao presente o passado, através da narrativa9 .

E como cultura de história se relaciona com literatura? Os autores das obras literárias também partilham deste mesmo conjunto de saberes históricos difundidos e conhecidos socialmente, e através de representações da história presentes nas obras literárias, e das inúmeras e variadas leituras ao longo do tempo, essas representações, de forma dialética, compõem parte da cultura de história. Dialética, pois o autor também está inserido nessa cultura de história e a partir do que a obra por ele(a) escrita apresenta, ou seja, as representações produzidas serão renovadas a partir da leitura e interpretação dos leitores. Esse é um movimento constante: assim, um(a) escritor(a), da mesma forma que consome, pois também é leitor(a), pode criar outras representações da história que serão lidas por outras pessoas que as usarão de formas variadas. O que corresponde a um movimento de retorno dessa cultura de história, uma dinâmica constante, como um ciclo contínuo no qual podem ocorrer transformações e/ou reafirmações de ideias e concepções acerca da história na sociedade. Essa cultura de história, dessa maneira, se conecta à memória coletiva e ao imaginário social sobre a história do país.

Para Paul Ricoeur a mimese, entendida como a mediação entre tempo e narrativa, se completa no ato de leitura, momento em que ocorre a "refiguração do mundo da ação" através do enredo. ${ }^{10}$ Nessa dissertação, considero que as representações da história se apresentam em obras literárias através da mimese. Essas representações miméticas da história, que ocorrem pela refiguração da experiência e do tempo através de enredos e narrativas, são possíveis através da familiaridade que os leitores possuem dessa

\footnotetext{
${ }^{8}$ Jorn RÜSEN, op.cit..., p.12.

${ }^{9}$ Ibidem, p. 11 .

${ }^{10}$ Paul RICOEUR. “A tríplice mímese”. In: Tempo e Narrativa. Tomo I. Constança Marcondes CESAR, (tradução). Campinas, SP: Papirus, 1994, p.118.
} 
experiência, que se insere numa narrativa já conhecida - aqui a Independência do Brasilque faz parte de uma memória coletiva e cultural. Julio Pimentel destaca uma abordagem de Umberto Eco, em Obra aberta, sobre a pertinência da ideia de contaminação entre ficcionalidade e representação da realidade. A questão levantada por Eco e discutida por Pimentel é extremamente relevante para essa pesquisa. Pimentel ressalta o compromisso distinto de obras ficcionais e históricas; entretanto, ressalta que "em nossas leituras, o lugar de representação da realidade e o espaço de ficcionalização, a despeito dos compromissos desiguais assumidos por um e por outro, perdem limites e realizam interferências recíprocas." ${ }^{11}$ Nesse sentido, tomamos as obras literárias como objeto importante para a análise de uma cultura de história e de representações da Independência.

Roger Chartier apresenta uma categoria de representação, e propõe que com ela é possível articular três modalidades da relação com o mundo social: primeiro, há um trabalho de configurações intelectuais que ocorre através de classificação e delimitação do que é representado. Tais configurações ganham contornos e significados que são apropriados de formas distintas por cada indivíduo ou grupo, e que podem criar visões contraditórias da realidade. Em seguida, as representações articulam uma maneira de comunicar simbolicamente um estatuto ou posição no mundo, bem como uma identidade. Assim, este aspecto da representação liga-se nesta pesquisa ao ordenamento de uma identidade comum em torno da nação, do Brasil independente e autônomo, ato simbólico e maneira de se posicionar frente a outras nações, sobretudo Portugal, assim como registro que ficou na história e é representado na historiografia e na literatura (dentre outros espaços possíveis). Por último, "as formas institucionalizadas e objetivadas graças às quais certos "representantes" (instâncias coletivas ou pessoas singulares) marcam, de modo visível e perpetuado, a existência do grupo, da classe ou da comunidade. ${ }^{12}$ Aqui também, a Independência - e suas representações - marca de forma irreversível o fenômeno que permite a constituição do Estado Independente, e de uma comunidade nacional comum de brasileiros.

O tema da Independência é pertinente para uma análise tal qual proposta nessa dissertação, pois faz parte da memória coletiva nacional e se conecta a formação do Estado e da nação e com o reconhecimento progressivo de uma identidade comum, a dos brasileiros. Também é tema que faz parte do ensino básico; é lembrada e celebrada em

\footnotetext{
${ }^{11}$ Júlio Pimentel PINTO, A leitura e seus lugares. São Paulo: Estação Liberdade, 2004, p.47.

${ }^{12}$ Roger CHARTIER, A história cultural: entre práticas e representações, Maria Manuela GALHARDO (trad.). Portugal: DIFEL, 2002, p.23.
} 
comemorações cívicas e abordada em produções culturais variadas como cinema, teatro, minisséries, revistas, vídeos da Internet, matérias jornalísticas, museus, por exemplo. ${ }^{13}$

Utilizando uma análise de longa duração para perceber possíveis reafirmações e/ou movimentos de transformação nas concepções e tratamento da Independência do Brasil, a variedade de gêneros literários também se mostra ideal por alcançar distintos públicos leitores e maneiras diversas de elaborar representações da história. Dessa forma, no escopo de objetos analisados nesta dissertação, foram escolhidos distintos gêneros literários, e não apenas obras canônicas de alta e profunda elaboração discursiva e autores de grande reconhecimento. Assim, temos 3 epopeias, 7 romances, um conjunto de poemas do modernismo, e um cordel. O intuito, com isso, é abarcar obras que tenham alcançado - e que ainda alcancem - públicos diversificados. Cabe esclarecer que não é nosso intuito elaborar uma história literária ${ }^{14}$, abordando características dos movimentos literários e evolução da literatura nacional. Propomos uma leitura historicizante das representações e conceitos empregados em cada uma das obras literárias, e tomadas em conjunto, compondo dessa forma uma análise de longa duração sobre as representações da Independência do Brasil.

Considerando características tão distintas das obras aqui analisadas, com graus de elaboração diversos e abordagens múltiplas, ou seja, elaborações focadas na história da Independência ou conflitos relacionados a seu processo, e outras que abordam o período com menções pontuais ou periféricas à narrativa, como verificar as representações da Independência nelas contidas? Tomando as obras literárias e representações nelas encontradas em conjunto, mesmo as menções pontuais e aparentemente sem importância, que reflitam sensos comuns, se repetidas acabam por elaborar ou demonstrar maneiras de concepção e tratamento da história. Por exemplo, o tratamento cômico dos personagens ou eventos demonstra um afastamento e rebaixamento de um tipo de história oficial, pretensamente elevada e heróica. Aquela é uma forma de representação da Independência e de alguns de seus personagens fortemente convencional. Esse tratamento é muito

\footnotetext{
${ }^{13}$ A exemplo do Museu do Ipiranga em São Paulo, idealizado e construído na década de 1880 para preservar a memória da Independência, e que "demarcou definitivamente o lugar da proclamação de 07 de setembro, assinalando, de forma imaginária, o ponto a partir do qual teria se originado a nação". Em: Cecília Helena de Salles OLIVEIRA, "O Museu Paulista da USP e a memória da Independência". Cad. CEDES. 2002, vol.22, n.58, p.65-80.

${ }^{14}$ Sobre o tema consultar: José VERÍSSIMO, História da literatura brasileira: de Bento Teixeira (1601) a Machado de Assis (1908. Rio de Janeiro: José Olympio, 1969; Alfredo BOSI, História Concisa da Literatura Brasileira. São Paulo: Cultrix, 1975; Silvio ROMERO, História da Literatura Brasileira, Rio de Janeiro: José Olympio, 1909; Antonio CANDIDO, Formação da Literatura Brasileira: Momentos Decisivos, 1750-1880. São Paulo: FAPESP, Rio de Janeiro: Ouro sobre Azul, 2009.
} 
utilizado em produções culturais variadas, em geral, através da sátira e que manifesta um modo coletivo de pensar a história da Independência e enxergar os personagens que dela fazem parte. Para parcela da sociedade, pode manifestar um modo crítico de conceber essa história; para outra parte, pode ser apenas a reprodução de um tipo de representação da Independência engendrada em um livro, ou um filme, por exemplo, que se mostrou mais marcante se fixando na memória.

No capítulo 1 será demonstrado como aspectos políticos da história da Independência foram apresentados nas obras, ou seja, se a Independência é vista como um processo, se destaca um recorte cronológico a eventos circunscritos em 1822, ou de maneira apenas anedótica, baseada em eventos que compõem o processo de Independência mas ganharam referências isoladas. Em seguida serão analisados alguns conceitos que se fizeram evidentes nas obras e que demonstram que muitos debates e interpretações estudadas na historiografia, de forma indireta, também são encontrados nas obras literárias. Dessa maneira, será possível perceber um consenso mínimo sobre a história da Independência do Brasil e assim torna-se lícito identificar as representações produzidas nas obras literárias. Com isso é viável, a partir dessas representações, mapear o entendimento e interpretações da história da Independência.

No capítulo 2 serão abordadas as caracterizações e representações dos personagens históricos nas obras. Também, a partir de Viva o povo brasileiro (1984), de João Ubaldo Ribeiro, será feita uma discussão em torno da desconstrução do mito de heróis da história, que se propõe no livro.

No terceiro e último capítulo serão observadas as formas como as identidades políticas, (múltiplas) no século XIX, se apresentaram nas obras, assim como serão analisadas imagens dos brasileiros baseadas em "sensos comuns". Na sequência serão apresentados os projetos e ideias de Brasil que foram encontrados nos objetos analisados, assim como uma discussão em torno da construção da memória da Independência e o exame sobre o tratamento que a história (concepções sobre história) recebeu nas obras.

Dessa maneira, foi possível identificar ao longo da análise muitas maneiras de representar o Brasil e os brasileiros. Além das incontáveis formas de representações da história da Independência, são possíveis leituras variadas dessas obras. Com isso, formam-se inúmeras imagens dos brasileiros, do Brasil e sua história, tal qual os múltiplos desenhos formados pela combinação de pedaços sortidos dos espelhos de um caleidoscópio. 
Para tanto, faz-se necessária, desde já, uma apresentação das obras e autores que compõem os objetos de análise da pesquisa. Como tais objetos serão constantemente mencionados durante toda a dissertação, e não necessariamente em ordem cronológica, mas sim a partir dos aspectos que estarão articulados pelos modos de possíveis interpretações,esta apresentação já introduzirá também como história e literatura foram articuladas em cada obra pelos autores.

\section{Apresentação das obras}

A primeira obra a ser apresentada é Paraguassú: Epopeia da Guerra da Independência na Bahia, escrita e originalmente publicada em 2 tomos, o Tomo I em 1835 e o Tomo II em $1837^{15}$. Ladislau dos Santos Titara (1801 - 1861) lutou nas batalhas da Independência na Bahia contra as tropas lusas comandadas pelo general Madeira de Melo. O autor do poema se associou a "militares e paisanos que a 19 e 20 de fevereiro tinham pelejado nas ruas contra a guarnição lusa"16. Seu batalhão foi sitiado no Forte de São Pedro, e como capitulariam, optaram pela fuga para o Recôncavo. Foram socorridos por dois batalhões de milícias da Torre, núcleo do Exército Pacificador, força que resistiu em três vilas do Recôncavo e que inverteu a situação depois de cinco meses. ${ }^{17}$ Em julho, Titara, com "honras de $2^{\circ}$ cadete, foi empregado na secretaria do Exército" 18 , momento em que teve acesso a ampla documentação sobre as mudanças de postos e cargos dos diversos batalhões do lado dos brasileiros. No paratexto da obra (as notas de rodapé) e nas notas ao fim de cada Canto escritas pelo autor, foram inseridas as alterações dos regimentos, nome e cargo de cada combatente, produzindo, ademais de um conjunto de representações literárias sobre a Independência, um valioso informe histórico acerca dos participantes das batalhas na Bahia entre 1822 e 1823.

O trabalho de Ladislau dos Santos Titara possui uma característica singular, pois trabalha com história e ficção, mesclando o relato histórico vivido, ou seja, o relato concebido a partir da participação do autor nas batalhas contra os partidários da manutenção do vínculo com Portugal integrando o exército independentista - aspecto que

\footnotetext{
${ }^{15}$ Em 1973 o poema completo foi publicado em edição fac-simile pelo Instituto Histórico e Geográfico Brasileiro, correspondendo ao volume VIII da coleção Brasiliensia Documenta. Essa edição foi utilizava na dissertação.

${ }^{16}$ Pedro CALMON, "Ladislau dos Santos Titara". In:Ladislau dos S. TITARA, Paraguassú: Epopeia da Guerra da Independência na Bahia.São Paulo: Empresa Gráfica da Revista dos Tribunais, 1973, p.12

${ }^{17}$ Ibidem, p.12.

${ }^{18}$ Ibidem, p.12.
} 
o diferencia das demais epopeias aqui analisadas - e referências de documentos, como jornais e aclamações feitas na época no paratexto, incorporando-as às bases da epopeia que possui referências mitológicas e construção narrativa fantasiosa com a inserção de sonhos, deuses e visões no poema. As notas, nomeando personagens que participaram das lutas que ocorreram na Bahia, o batalhão de que cada um fazia parte, sua respectiva patente, assim como as localizações geográficas e nomes (muitos deles de origem indígena) dos rios, serras, flora e cidades, são muito ricas. As referências históricas que o autor apresenta na obra são profusas, e assim como nos outros épicos desta pesquisa temos dois textos na obra: a narrativa épica que, como Teixeira e Sousa, mescla história e ficção; e o paratexto nas notas de rodapé e notas ao fim de cada Canto que explicam alguns eventos. No caso de Titara, muitas das notas foram inseridas a partir do acesso à documentação das tropas brasileiras configurando dessa forma um relato/documento histórico.

A narrativa de Titara possui forte traço retórico, e por tratar das lutas contra os portugueses, há menções no poema que produzem um plano de elogio e defesa da pátria e da Bahia; e um plano em que os portugueses são tratados como inimigos com o uso de colocações pejorativas.

Em seguida, temos o poema épico A Independência do Brasil-Poema Épico em XII Cantos, de Antonio Gonsalves Teixeira e Sousa, publicado em dois tomos: o primeiro em 1847 e o segundo em $1855 .{ }^{19}$ Nessa epopeia, ficção e história se misturam quando, acompanhando o saga do herói D. Pedro, são utilizados artifícios próprios do estilo, como Anjos, a Musa, deuses, ou a própria História, ou a Anarquia e Liberdade, por exemplo, que são personificadas, se tornando sujeitos ou "entidades". A história é narrada nessa saga através da voz do próprio herói e de outros personagens, em diálogos. Ou ainda na voz poética do narrador, com emulação de discursos reais, como os realizados nas Cortes Portuguesas. Há ainda o paratexto ao final de cada Tomo, com algumas explicações que funcionam como notas de rodapé do poema.

Teixeira e Sousa ${ }^{20}(1812$ - 1861) é oriundo de Cabo Frio, no Rio de Janeiro.

\footnotetext{
19 Antonio Gonsalves TEIXEIRA E SOUSA. A Independência do Brasil: Poema épico em XII Cantos. Tomo I. Rio de Janeiro: Typ. Imparcial de Francisco de Paula Brito, 1847; e Antonio Gonsalves TEIXEIRA E SOUSA. A Independência do Brasil: Poema épico em XII Cantos. Tomo II. Rio de Janeiro: Emp. Typ. Dous de Dezembro de P. Brito, 1855.

${ }^{20}$ Sobre o autor ver: Joaquim Norberto de SOUZA E SILVA. Biografia dos brazileiros ilustres: Notícia sobre Antônio Gonçalves Teixeira e Sousa e suas obras. T. 39, v.52, Rio de Janeiro: IHGB, 1876, p.197216; Silvio ROMERO, História da literatura brasileira. Tomo II. Edição Comemorativa. Luiz Antonio BARRETO (org.). Rio de Janeiro: Imago Editora; Aracaju: Universidade Federal de Sergipe, 2011, p. 654663; Antonio CANDIDO, A formação da literatura brasileira: Momentos decisivos, 1750-1880. 10.ed. Rio
} 
Vindo de uma família humilde, teve apenas o ensino das primeiras letras, aprendendo o ofício de carpinteiro em 1822 por necessidade. Em 1825 se mudou para o Rio de Janeiro, lá permanecendo até 1830. Retornou a Cabo Frio sendo nomeado mestre-escola; em 1855 virou escrivão no Rio de Janeiro, falecendo em $1^{\circ}$ de dezembro de $1861 .{ }^{21}$ Silvio Romero e Antonio Candido escreveram críticas e perfis severos sobre a obra do escritor ${ }^{22}$. Romero classificou Teixeira e Sousa como "patriota e nacionalista; [que] forcejava por tomar parte nos esforços da geração de seu tempo no empenho de dotar o Brasil com uma literatura."23 Essa característica patriótica é notória na epopeia aqui analisada $A$ Independência do Brasil: poema épico em XII Cantos ${ }^{24}$. Antonio Candido, lembrou o tratamento dispensado à produção de Teixeira e Sousa por outros críticos, ressaltando que "um anônimo do Correio Mercantil, por ventura Gonçalves Dias, desanca de tal modo a sua epopeia nacionalista que ele desiste de continuar, terminando-a afinal quase dez anos mais tarde." 25

O poema possui um aspecto pedagógico sobre a história do Brasil e a Independência, com o enaltecimento da nação e da pátria nascentes, bem como da figura de D. Pedro I como o herói libertador do Brasil. A obra foi dedicada a D. Pedro II e sua família. Nele, há uma referência a poemas épicos da Antiguidade, seguidos como modelo na narrativa das histórias e aventuras do herói, com as dificuldades e batalhas que enfrenta e vence. É perceptível que o poema é coerente com a construção de uma história e de uma memória oficiais do processo de Independência. Cabe lembrar que D. Pedro II, através do Instituto Histórico e Geográfico Brasileiro (IHGB), trabalhou de forma a consolidar a identidade e nação brasileiras. ${ }^{26} \mathrm{O}$ IHGB “engajava-se em tarefa árdua e contraditória: forjar uma identidade para a emergente nação brasileira, elaborando a ruptura com o

de Janeiro: Academia Brasileira de Letras: Ouro sobre Azul, 2006,444-452; José VERÍSSIMO, História da literatura brasileira: de Bento Teixeira (1601) a Machado de Assis (1908). Rio de Janeiro: J. Olympio, 1969. ${ }^{21}$ Silvio ROMERO, História da literatura brasileira. Tomo II. Edição Comemorativa. Luiz Antonio BARRETO (org.). Rio de Janeiro: Imago Editora; Aracaju: Universidade Federal de Sergipe, 2011, p. 654663.

${ }^{22}$ Antonio Gonsalves Teixeira e Sousa (na grafia atual seu nome é escrito Antonio Gonçalves Teixeira e Sousa) escreveu duas tragédias "Cornélia" e "O Cavaleiro Teutônico"; uma coleção de poemas chamada "Cânticos Líricos" e o poema épico "A Independência do Brasil. Poema épico em XII Cantos". Em: Silvio ROMERO, op.cit., 2011, p.654. Também publicou "O filho do pescador" considerado o primeiro romance brasileiro, "Tardes de um pintor ou As intrigas de um jesuíta", "Gonzaga ou A conjuração de Tiradentes", "Maria ou a menina roubada", "A providência" e "As fatalidades de dois jovens". Em: Antonio CANDIDO, A formação da literatura brasileira: Momentos decisivos, 1750-1880. 10.ed. Rio de Janeiro: Academia Brasileira de Letras: Ouro sobre Azul, 2006, p.444 - 445. As críticas de Romero e Candido se encontram nessas duas obras citadas.

${ }^{23}$ Silvio ROMERO, op.cit., 2011, p.654-655.

${ }^{24}$ No restante da dissertação o poema será referido como "épico ou epopeia da Independência".

${ }^{25}$ Antonio CANDIDO, op.cit, 2006, p.444.

${ }^{26}$ Manoel Luis Lima Salgado GUIMARÃES. Nação e Civilização nos Trópicos..., op.cit., 1988. 
passado ibérico ao mesmo tempo que procedia à americanização da monarquia." ${ }^{27}$ Assim, não é de se estranhar que um poema como o de Teixeira e Sousa apresente esta característica didática, no sentido de ensinar uma história (oficial) do Brasil. É nele notória a intenção de consolidar a memória em torno da Independência como ato fundador do Estado brasileiro, demarcando o processo de emancipação como fruto da maioridade do germe da identidade nacional.

Seguindo as epopeias, temos também Primícias - Poema dos principaes factos da História do Brasil até sua Independência, publicado em $1900^{28}$. Este poema foi escrito por Joaquim Gil Pinheiro, um português nascido em 1855 que mudou-se para o Brasil em 1878, se instalando primeiramente no Rio de Janeiro, seguindo para São Paulo. Viveu ainda em São Bernardo do Campo, viajou pelo interior de São Paulo e sul de Minas Gerais instalando-se definitivamente em São Paulo. Trabalhou em diversas atividades, de comércio e fabricação de velas de cera até criação de abelhas, e dedicando-se também à poesia. $^{29}$ Como consta no Prefácio, a obra foi dividida em quatro partes: Prefácio; prólogo; um "poemeto" no final da obra, que o autor declamou a bordo de um navio, e o poema histórico

dos usos, costumes, crenças e artes dos selvagens, assim como da sua descoberta e os episódios principais da história colonial brasileira até a sua independência, dividida em oito cantos, de modo que de hoje em diante qualquer menino brasileiro poderá cantar na escola a história de sua pátria, e deste cântico talvez ter maior proveito do que de outras poesias adaptadas... ${ }^{30}$

Com isso, percebe-se que temos uma obra com fins instrutivos e elogiosa aos feitos dos portugueses:

[...] na qual relata fatos dos mais honrosos para os arrojados portugueses que vieram colonizar esta terra de Santa Cruz, descoberta no ano de 1500 pelo intrépido e ilustre português Pedro Alvares de Cabral, de cujo acontecimento importantíssimo está prestes a chegar o quarto centenário, que será

\footnotetext{
${ }^{27}$ Wilma Peres COSTA. "A Independência na historiografia brasileira”. In: István JANCSÓ (org.), Independência: História e historiografia. São Paulo: Hucitec: FAPESP, 2005, p.57.

${ }^{28}$ Joaquim Gil PINHEIRO. Primícias: poema dos principaes factos da História do Brasil até sua Independência, São Paulo: (não consta tipografia), 1900.

${ }^{29}$ Informações retiradas do prefácio da obra. Em: Joaquim Gil PINHEIRO, op.cit., p. 5-9.

${ }^{30}$ Joaquim Gil PINHEIRO, op.cit., p.11 e 12.
} 
pomposamente festejado, tanto aqui como em Portugal. ${ }^{31}$

O autor era um português emigrado para o Brasil, portanto, sua obra tem por intenção declarada homenagear os grandes feitos portugueses. O poema é elaborado em versos rimados, com o paratexto (notas de rodapé) com explicações sobre a História, eventos e personagens, e considerações do autor. De maneira diversa da epopeia de Teixeira e Sousa, não há utilização de elementos alegóricos ficcionais como anjos, deuses, etc.

Seguimos com a obra de Manuel Antonio de Almeida, seu único romance publicado $^{32}$, Memórias de um sargento de milícias ${ }^{33}$, primeiramente como folhetim no jornal Correio Mercantil. O primeiro capítulo foi publicado em 27 de junho de 1852, e o último em 31 de julho de 1853. A primeira versão do romance no formato de livro saiu em 2 volumes, o primeiro lançado em 1854 e o segundo, em $1855 .{ }^{34} \mathrm{Na}$ edição lançada em 2013, Ruy Castro escreveu o prefácio sobre a obra, com a biografia do autor e análise do romance.

Em Memórias de um sargento de milícias (1852-1853) acompanhamos a trajetória de Leonardo, o protagonista, desde sua concepção até o momento em que se torna um sargento de milícias. Esse é um romance do tipo picaresco, com escrita cômica, e apresenta tipos populares e costumes da época. A obra é demarcada com a frase inaugural: "Era no tempo do rei”. Como explica Antonio Candido:

Manuel Antonio deseja contar de que maneira se vivia no Rio popularesco de D. João VI: as famílias mal organizadas, os vadios, as procissões, as festas, as danças, a polícia; o mecanismo dos empenhos, influências, compadrios,

\footnotetext{
${ }^{31}$ Ibidem, op.cit., p.11.

${ }^{32}$ Antonio Manuel de ALMEIDA. Memórias de um Sargento de Milícias. São Paulo: Penguim Classics Companhia das Letras, 2013.

33 Sobre a obra, consultar: Antonio CANDIDO. "Dialética da Malandragem". Revista do Instituto de Estudos Brasileiros, São Paulo, n. 8, p. 67-89, junho 1970. Jean Pierre CHAUVIN. O poder pelo avesso: mandonismo, dominação e impotência em três episódios da literatura brasileira. Tese de Doutorado. Faculdade de Filosofia, Letras e Ciências Humanas (USP). São Paulo, 2006; Gabriela Hatsue Yuasa AZEKA. Um enjeitado e um sargento de milícias: formação do indivíduo e do romance. Tese de Doutorado. Faculdade de Filosofia, Letras e Ciências Humanas (USP), São Paulo, 2006; Edu Teruki OTSUKA. "Espírito rixoso: para uma reinterpretação das Memórias de um sargento de Milícias". In: Revista do Instituto de Estudos Brasileiros, São Paulo, n.44, p.105-124, fev.2007.

34 Ruy CASTRO. "Prefácio". In: Manuel Antonio de ALMEIDA. Memória de um sargento de milícias. São Paulo: Penguim Classics Companhia das Letras, 2013, p.9-10. As informações sobre a biografia do autor foram escritas na $1^{\text {a }}$ edição do prefácio de Ruy Castro, que apresenta sua biografia e análise da obra de Manuel Antonio de Almeida.
} 
punições, que determinavam uma certa forma de convivência e se manifestavam por certos tipos de comportamento. ${ }^{35}$

O foco do romance incide sobre tipos sociais, festas de rua e religiosidade, e a história do protagonista Leonardo, (tipificando o brasileiro - símbolo da malandragem). Dessa forma, são tratados costumes, numa esfera pública e privada no Rio de Janeiro do período joanino.

Outro romance da segunda metade do século XIX, mas cuja construção da narrativa e personagens é mais sofisticada e complexa que a anterior, é Memórias Póstumas de Brás Cubas, ${ }^{36}$ de Machado de Assis. Foi publicado primeiramente como Folhetim na Revista Brasileira, a partir de março de 1880, e em livro em $1881^{37}$. O livro ocupa o centro da obra de Machado de Assis ${ }^{38}$, e por muitos críticos é tida como a obra de virada do estilo machadiano. Este romance marca a passagem do Romantismo para o Realismo no panorama literário no Brasil, e o narrador do romance inclusive faz críticas irônicas às características marcantes do romantismo. ${ }^{39}$

O narrador e protagonista, Brás Cubas, provoca e rebaixa o leitor a todo momento, o ofendendo. Não temos aqui o tipo de construção em que se mobiliza o leitor a duvidar se o que está posto na obra é real ou ficção, mas temos uma construção que estabelece uma relação de desconfiança do leitor com o narrador, e de mimese com a sociedade, ou

\footnotetext{
${ }^{35}$ Antonio CANDIDO, Formação da literatura brasileira: Momentos decisivos, 1750-1880. 10 ed. Rio de Janeiro: Academia Brasileira de Letras: Ouro Sobre Azul, 2006, p.534.

${ }^{36}$ Sevcenko aponta uma discussão acerca da classificação dos romances de Machado de Assis como romances realistas, e adota Memória Póstumas de Brás Cubas como uma sátira menipéia. Em: Nicolau SEVCENKO, "A ficção capciosa e a história traída". In: John GLEDSON. Machado de Assis: ficção e história. Sônia COUTINHO (tradução). São Paulo: Paz e Terra, 2003, p.13-35. Sobre o assunto ver: José Guilherme MERQUIOR. "Gênero e estilo nas memórias póstumas de Brás Cubas". Colóquio/Letras, v.8, 1972, p.12-20; e também: Enylton de Sá REGO, "Machado de Assis e a sátira menipéia: um diálogo com os textos de Luciano", Letterature d'America, n.4, 1983, p.15-38.

${ }^{37}$ Machado de ASSIS. Memórias Póstumas de Brás Cubas. São Paulo: Penguin Classics Companhia das Letras, 2014.

${ }^{38}$ Foram feitos vários estudos sobre este livro de Machado de Assis, para maior entendimento, cito alguns: Antonio CANDIDO. "Esquema de Machado de Assis". In: Vários escritos. São Paulo: Duas Cidades, 1970, p.15-32; John GLEDSON. Machado de Assis: Fiç̧ão e história..., op.cit ,2003. Do mesmo autor: John GLEDSON. Machado de Assis: impostura e Realismo. São Paulo: Companhia das Letras, 1991. Roberto SCHWARZ. Um mestre na periferia do capitalismo: Machado de Assis. São Paulo: Livraria Duas Cidades, 1990.

${ }^{39}$ Informações do prefácio da edição da Penguin \& Companhia das Letras, escrito por Hélio de Seixas GUIMARÃEES. O pesquisador esclarece que se tratando de Machado as divisões e categorias literárias não são tão simples e claras: "Se nos primeiros romances ele dialoga com os procedimentos e as convenções do romance romântico mais rotineiro, tomando distância e criticando suas simplificações, a partir de Brás Cubas esse diálogo crítico também se faz com as convenções do realismo e do naturalismo, frequentemente parodiados e ridicularizados.". Em: Hélio de Seixas GUIMARÃES, "Prefácio: Um monumento chamado Brás Cubas". In: Machado de ASSIS. Memórias Póstumas de Brás Cubas. São Paulo: Penguin Classics Companhia das Letras, 2014, p.11-13.
} 
seja, uma construção a partir da verossimilhança com tipificação de personagens e caracterização do Rio de Janeiro no século XIX. A vida de Brás Cubas acompanha a história do Brasil, e amarrando a trajetória e as memórias após a morte do narrador, também acompanhamos transformações políticas do Brasil. Os personagens representam tipos, e são caracterizados em sua profundidade e complexidade de sujeitos. Brás Cubas é um homem da elite, de Letras, foi enviado à Portugal para estudar, voltou para o Brasil pelo falecimento de sua mãe, trabalhou num jornal, tentou ascender à um cargo político e ficou obcecado com a ideia do emplasto Brás Cubas, momento em que faleceu. O recorte da obra vai de 1805 a 1869 , e vamos focar aqui, sobretudo no que diz respeito às representações da história entre a chegada da Corte, em 1808, e a abdicação de D. Pedro, em 1831.

Temos ainda a publicação de Murilo Mendes, História do Brasil, com sua primeira edição publicada em 1932 no Rio de Janeiro ${ }^{40}$, pela Ariel Editora, com capa feita por Di Cavalcanti. ${ }^{41}$. Tratam-se de poemas satíricos, carregados de ironia e excluídos pelo próprio autor de sua obra poética reunida em $1959^{42}$. De acordo com a organizadora da edição utilizada nesta pesquisa ${ }^{43}$ - que corresponde a segunda edição publicada da obra em 1991 -, Luciana Picchio, essa rejeição do poeta se deve pela ironia "modernista de primeira fase: a fase dos poemas-piadas, das antropofagias, do 'vamos descobrir o Brasil'. ${ }^{44,}$

Murilo Mendes nasceu em 13 de maio de 1901, em Juiz de Fora, Minas Gerais. Seu pai era funcionário público, e Mendes, com um ano e meio de idade, perdeu a mãe, sendo criado pela segunda esposa do pai, Maria José. Exerceu inúmeras atividades: telegrafista, prático de farmácia, guarda-livros, funcionário de cartório, professor de

\footnotetext{
${ }^{40} \mathrm{O}$ pesquisador José Alberto Pinho NEVES aponta em sua pesquisa de doutorado, que através do Boletim de Ariel, revista carioca criada em outubro de 1931 pela Ariel Editora Ltda, em que Murilo Mendes colaborou de 1931 a 1938, foi possível esclarecer o ano de publicação de História do Brasil. Segundo o pesquisador aponta, foi em 1933. José Alberto Pinho NEVES, História do Brasil de Murilo Mendes: travessia para o conhecimento. Tese de doutorado. Programa de Pós-graduação em Educação da Universidade Federal de Juiz de Fora. Juiz de Fora, Minas Gerais, 2016, p.214-224.

${ }^{41}$ José Alberto Pinho NEVES,op.cit., 2016, p.12. De acordo com o autor, a capa elaborada por Di Cavalcanti já anunciava o caráter risível dos acontecimentos presentes na leitura do texto: "um cortejo debochado, irônico, desordenado, de personagens da história do Brasil, condizente com a alma modernista da década de 1920 e 1930." ( p.208). A segunda edição, de 1991, perderia essa capa ganhando concepção gráfica de Victor Burton, a partir do Retrato de Murilo Mendes, pintado pelo amigo do poeta, Alberto da Veiga Guignard. (p.239-240)

${ }^{42}$ Murilo MENDES. História do Brasil (1932). PICCHIO, Luciana Stegagno (organização, introdução e notas). Rio de Janeiro: Nova Fronteira, 1991, p.5.

${ }^{43}$ Ibidem, 1991.

${ }^{44}$ Murilo MENDES. História do Brasil (1932)...op.cit,p.5
} 
francês, arquivista do Ministério da Fazenda no Rio de Janeiro, para onde se mudou definitivamente em $1920 .{ }^{45}$

Essa obra de Murilo Mendes se insere no contexto do Modernismo no Brasil, em que ocorre uma busca da nacionalidade, o rompimento com padrões herdados e com isso a negação de uma herança portuguesa, com "apelo ao humor e o deboche e reflexão de nossa identidade. ${ }^{46}$

João Luiz Lafetá esclarece que o movimento modernista foi formado por duas esferas: a estética e a ideológica. A primeira buscava uma "renovação dos meios e uma ruptura da linguagem tradicional". ${ }^{47}$ A esfera ideológica baseava-se numa consciência do país, buscando uma expressão artística nacional e o caráter de classe de suas atitudes e produções. $^{48} \mathrm{O}$ autor aponta que a experimentação estética do movimento foi revolucionária, sobretudo nos primeiros anos do movimento, momento em que se propunha uma mudança radical na concepção da obra de arte. ${ }^{49}$ Lafetá destaca uma convergência entre os planos estético e ideológico: o "rompimento com a linguagem bacharelesca, artificial e idealizante que espelhava, na literatura de 1890-1920, a consciência ideológica da oligarquia rural instalada no poder [...]"50

Larissa Agostini Cerqueira explica que, para João Luiz Lafetá, o modernismo teria em cada uma de suas fases a predominância de uma dessas características: na primeira, período que compreende as produções das décadas de 1920 e $1930^{51}$, teria ocorrido a predominância do caráter estético. ${ }^{52}$ É nesse momento em que a obra História do Brasil de Murilo Mendes se insere, e o que se verifica é a utilização de linguagem popular, a ironia e o chiste na construção dos poemas.

\footnotetext{
${ }^{45}$ Luciana Stegagno PICCHIO, "Vida-poesia de Murilo Mendes". In: Murilo MENDES, Poesia completa e prosa, volume único. Luciana Stegagno PICCHIO (org. e preparação de texto). Rio de Janeiro: Nova Aguilar, 1994, p.24. Sobre Murilo Mendes consultar também: Jayme Eduardo LOUREIRO, A formação de um enfant terrible: poetização e resistência em A idade do serrote. Tese de Doutorado. Faculdade de Filosofia, Letras e Ciências Humanas da Universidade de São Paulo, 2009.

${ }^{46}$ Maria Laura Muller da FONSECA E SILVA, "Entre dois mundos. O intelectual brasileiro e as experiências fora do lugar". In: Darandina Revista eletrônica. Programa de Pós-Graduação em Letras/UFJF, volume 7, número 1, p.8.

${ }^{47}$ João Luiz LAFETÁ, "Os pressupostos básicos". In: 1930: a crítica e o modernismo. São Paulo: Duas Cidades, 1974, p.12.

${ }^{48}$ Ibidem, p.12.

${ }^{49}$ Ibidem, p. 12.

${ }^{50}$ Ibidem, p.12-13.

${ }^{51}$ A fase posterior compreende as produções da década de 1940. A pesquisadora também esclarece que o termo "ideológico" utilizado por Lafetá equivale ao âmbito político-social da arte. Em: Larissa Agostini CERQUEIRA, "As contribuições do modernismo para a literatura e a crítica brasileiras"; In: Em Tese, vol.16, n.2, ago.2010, ISSN1982-0739, p.7-8.

${ }^{52}$ Ibidem, p.7
} 
Os poemas de Murilo Mendes escolhidos para análise foram: "Embarque do papagaio real", sobre a transferência da Corte portuguesa para o Brasil; "A mão de Domingos José Martins", poema sobre a Revolução de Pernambuco de 1817 contado em formato de romance popular ${ }^{53}$; "Relíquias de Frei Caneca", sobre o personagem; "Fico", sobre o dia em que o Príncipe D. Pedro anunciou sua decisão de desobedecer as ordens das Cortes de Portugal e permanecer no Brasil; "Preparativos da Pescaria", sobre os antecedentes da Declaração da Independência; "Serenata da Dependência", versa sobre uma conversa de D. Pedro com uma amante se referindo ao Reino português dependente economicamente da Grã-Bretanha; e "A pescaria", sobre a declaração da Independência às margens do Ipiranga. ${ }^{54}$

A obra seguinte foi escrita por João Ubaldo Ribeiro, escritor que nasceu em Itaparica, na Bahia, em 23 de janeiro de 1941, falecendo no Rio de Janeiro, em 18 de julho de 2014. No ano de publicação de Viva o povo brasileiro, 1984, o escritor já havia publicado sete livros, dentre ele Sargento Getúlio (1971) que foi muito premiado. A partir do sucesso dessa publicação, João Ubaldo, passou uma temporada no curso de literatura de Iowa (EUA) e recebeu uma bolsa em Portugal. Em seguida conseguiu um contrato como cronista fixo do jornal $O$ Globo. ${ }^{55}$

João Ubaldo exerceu diversas atividades: iniciou-se no jornalismo ainda cursando Direito no final dos anos 1950, passou para a publicidade, seguiu para o meio acadêmico lecionando Ciência Política na Universidade Federal da Bahia por seis anos, e voltou ao jornalismo em $1971^{56}$. Seu primeiro romance, Setembro não tem sentido ${ }^{57}$, foi publicado em 1968, e contou com incentivo e posfácio escrito pelo cineasta Glauber Rocha.

Viva o povo brasileiro (1984) contém muitos personagens e possui uma extensão cronológica longa, começando no século XVII (1647) e finalizando no século XX (1977), totalizando 20 capítulos. Não há uma ordem cronológica rigorosa, uma vez que a narrativa se desenvolve por blocos, entre idas e vindas de anos próximos. O livro passa por vários momentos da história do Brasil e apresenta tipos nos personagens. Assim, temos a

\footnotetext{
${ }^{53}$ Murilo MENDES. História do Brasil (1932); Luciana Stegagno PICCHIO (org., introdução e notas). Rio de Janeiro: Nova Fronteira, 1991, p.100.

${ }^{54}$ Ibidem, p.100-102.

${ }^{55}$ Rodrigo LACERDA, “673 páginas, seis quilos e seiscentos gramas”. In: João Ubaldo RIBEIRO, Viva o povo brasileiro, edição especial de 30 anos. Rio de janeiro: Objetiva, 2014, p.7.

${ }^{56}$ Ibidem, p.7

${ }^{57} \mathrm{O}$ enredo de Setembro não tem sentido apresenta duas histórias contadas paralelamente. Em uma delas acompanhamos um grupo de jovens boêmios nos eventos públicos comemorativos do 7 de setembro, na Semana da Pátria, em Salvador. Muito politizados, são ressaltados os tumultos que o grupo provocava. A outra história apresenta a rotina de um jornalista aposentado, amargurado que vive recluso. João Ubaldo RIBEIRO, Setembro não tem sentido. $4^{\mathrm{a} e d .}$ Rio de Janeiro: Objetiva, 2012.
} 
caracterização de senhores da elite política e escravista no Brasil, com a apresentação de ponto de vista da classe dominante, com projetos e ideias do Brasil expressos na voz dos personagens que tipificam esse grupo. Há também outros lados, nas vozes e ações de escravizados e subalternos, com questionamentos ao sistema escravista e o destaque a um outro projeto de Brasil por eles almejado. Também há personagens conservadores que apoiavam a ditadura civil-militar no Brasil, assim como personagens que se opõem ao regime militar.

A crueldade de senhores de escravos e de uma classe dominante com cativos é ressaltada na obra. Na construção da obra é feito o uso de um humor irônico, sarcástico, ácido, com linguagem crua e direta. Há ainda a emulação da linguagem falada, no caso, nas vozes dos personagens cuja língua nativa não era o português, o que configura um modo de falar popular. No livro de João Ubaldo Ribeiro são representados aspectos da escravidão no Brasil: cruel, bruta, crua, com cenas de castigos e estupros de cativas descritos de forma minuciosa e detalhada. A história é misturada com a ficção nesta obra, e personagens históricos são citados por personagens ficcionais. Esses, transitam e participam de muitos momentos históricos. A maior parte do enredo se passa na Bahia, na região do Recôncavo Baiano. Os eventos da Independência que ocorreram na região são destacados, assim como os personagens históricos citados que participaram das lutas pela Independência na Bahia.

Em Viva o povo brasileiro (1984) encontramos muitas provocações acerca da História, sua escrita e memória. É na voz dos personagens ou do narrador que essas provocações e reflexões são colocadas. No caso da Independência, levanta questionamentos sobre a construção de personagens elevados a heróis da História, que chamo nessa dissertação de "mitos" de heróis da Independência e da história; ou apresenta discussões sobre projetos de Brasil que se delineavam na voz dos personagens que fazem parte da classe dominante e dos subalternos; questões identitárias também são trabalhadas. Entretanto, como esses temas são colocados através da ficção na narrativa, o repertório do leitor possui extrema importância para que as conexões e reflexões sobre a História sejam feitas.

O romance que segue é Galantes Memórias e Admiráveis Aventuras do Virtuoso Conselheiro Gomes, $O$ Chalaça $^{58}$, cujo protagonista é o personagem que dá nome ao livro

\footnotetext{
${ }^{58}$ José Roberto TORERO. Galantes memórias e admiráveis aventuras do virtuoso Conselheiro Gomes, o Chalaça. São Paulo: Companhia das Letras, 1994.
} 
de José Roberto Torero, lançado em $1994^{59}$. Temos na apresentação do livro (a orelha da capa) feita por D. Pedro, um texto supostamente "psicografado". E, mais uma vez, o entrecruzamento entre a história e a ficção são explorados:

Atesto para todos os fins que tudo o que neste livro se verá é verdadeiro, e que todas as palavras aqui escritas andam de mãos dadas com a verdade - embora uma ou outra vírgula possam ter sido inventadas... Pode ser que o Chalaça falte com a verdade em alguns trechos, mas não o julguemos mal. Se há exageros e omissões em sua narrativa, é porque assim funciona a memória, prolongando vitórias e dissimulando derrotas. Talvez por conta disso ele seja acusado de imprecisão histórica, mas o leitor há de convir que a ciência da história fica ainda mais bela se enfeitada pela arte do mentir, e nisso o autor deste livro mostra-se inigualável. ${ }^{60}$

Torero vale-se do artifício (algo similar ao do narrador-defunto de Machado de Assis ${ }^{61}$ ) de usar o monarca que manda uma mensagem psicografada (do além-túmulo), o que supostamente atestaria a veracidade do relato. De acordo com a apresentação do "defunto D. Pedro I" feita através de psicografia, os "exageros e omissões da narrativa" devem ser perdoados, já que se tratam de memórias, e a memória pode ser traiçoeira. E, por esse motivo, o Chalaça poderia ser acusado de imprecisão histórica, mas a história enfeitada com mentiras, arte muito bem manipulada pelo Conselheiro Gomes, se torna ainda mais atraente. Essa tática de colocar o defunto D. Pedro I apresentando o livro através de uma carta psicografada, quebra o aspecto de verossimilhança, e embora o autor tente inserir a dúvida sobre a existência do diário de Chalaça mais à frente, esta apresentação já seria a indicação de que se trata de uma ficção. A linguagem empregada é cômica,e em alguns momentos chula, mas caso um leitor desatento parta para a leitura sem considerar a apresentação na orelha do romance, pode ficar em dúvida se o livro

\footnotetext{
${ }^{59}$ Este romance foi parcialmente analisado no artigo: João Paulo Garrido PIMENTA; César ATTI; Sheila Virginia CASTRO; Nadiesda DIMAMBRO; Beatriz Duarte LANNA; Marina PUPO; Luís Otávio VIEIRA. "A Independência e uma cultura de história no Brasil"..., op.cit.,2014. Nesta dissertação aprofundamos a análise.

${ }^{60}$ José Roberto TORERO. Galantes memórias e admiráveis aventuras..., op.cit., 1994.

${ }^{61}$ A aproximação se dá pela inserção das obras na tradição da sátira menipéia.Camila Marcelina PASQUAL. O Chalaça, de José Roberto Torero: o romance e o diálogo com a tradição. Dissertação de Mestrado em Literatura Brasileira. Universidade Federal de Santa Catarina (UFSC), Florianópolis, 2006. Referência encontrada em: Stanis David LACOWICZ. Mitos hispânicos no romance brasileiro: uma leitura de O Chalaça (1994) e de O feitiço da ilha do Pavão (1997). Dissertação de Mestrado. Faculdade de Ciências e Letras de Assis - UNESP, Assis, 2012.
} 
expõe um relato histórico - uma versão da história a partir do ponto de vista do narrador, já que se trata do "suposto diário" do Chalaça - ou de uma ficção.

Esse artifício de deixar o leitor em dúvida sobre a existência do diário e sobre a veracidade do relato é explorado pelo autor no Prefácio, no qual explica que o suposto diário do Conselheiro Gomes é buscado por historiadores, dentre os quais ele se inclui (embora no próprio livro seja apresentada sua graduação em Letras e Jornalismo), pois o Chalaça viveu no período da Independência. Explica também que o diário é citado brevemente em dois livros portugueses: Meus Cavalos e Meus Amigos, de João Carlota; e Minha Vida na Corte de Portugal e as Boas Maneiras que Nela se Deve Praticar, de João da Rocha Pinto. Trata-se de ficção, entretanto, o escritor fornece essas informações para confundir o leitor, deixá-lo em dúvida. Torero supõe validação da existência desse diário com acadêmicos (fictícios) o que sugere que tenha realmente apresentado algum material para ser analisado por especialistas na Academia. Entretanto, ao mesmo tempo em que tenta criar uma dúvida no leitor, o autor dá pistas que isso não foi validado ${ }^{62}$. Torero constrói uma história e um cenário que tenta convencer o leitor que o diário realmente existiu, mas fornece indícios de que se trata de uma ficção. Utilizando este artifício no início do livro, o autor cria condições para uma leitura questionadora e desconfiada por um leitor hesitante diante do relato. Este também é um modo de prender o leitor à narrativa, tornando-o instigado pela curiosidade diante da dúvida se é um relato verdadeiro, ou seja, se é o suposto diário do Chalaça, ou uma ficção.

Existe, de fato, um livro de memórias publicado por Francisco Gomes da Silva, Memorias Offerecidas á nação brasileira, editado em Londres em 1831. O que sugere que pode ter sido a fonte de inspiração para o romance de Torero, embora não seja citado. Curioso inclusive, que nas memórias publicadas por Gomes em 1831, ele esclarece:

Protesto, repito, não faltar ao rigor da verdade: pode ser que me engane a memória a respeito de datas; mas a memória do coração é mais duradoura e mais fiel que a outra: nunca se perde a lembrança dos motivos que nos induziram a praticar uma ação: estes motivos são sempre presentes quando se faz comemoração dela. ${ }^{63}$

\footnotetext{
${ }^{62}$ Stanis David LACOWICZ. Mitos hispânicos no romance brasileiro..., op.cit, p.19-23. Lacowitz aponta que no prefácio já apresenta-se uma ficção, seria o alter-ego do autor Roberto Torero, que apresenta-se como pesquisador.

${ }^{63}$ Francisco Gomes da SILVA. Memorias offerecidas á nação brasileira. Pelo Conselheiro Francisco Gomes da Silva. Londres: Impresso por L.Thompson, 19, Great St.Helens, 1831, p.16.
} 
É possível perceber uma aproximação entre o que foi escrito por Gomes em suas memórias publicadas em 1831, e a apresentação do livro de Torero "psicografada", feita pelo defunto D. Pedro, a respeito da memória e imprecisões históricas do protagonista da história.

No romance de Torero, temos um narrador residindo na Europa (período que configura o tempo presente deste narrador), e uma outra narrativa dentro dessa história que é a autobiografia que Chalaça está escrevendo, as duas narrativas compondo o suposto diário de Chalaça. São dois planos de narrativas: o presente se passa no período em que o Conselheiro Gomes está em Paris e é convocado por D. Pedro IV ${ }^{64}$, pois travara guerra com D. Miguel por usurpar o trono de sua filha D. Maria. E o passado (autobiográfico), que são suas memórias do período em que viveu no Brasil. O protagonista e narrador é o próprio Chalaça, e a história é contada a partir de seu ponto de vista.

Da mesma forma como acontece em Memórias Póstumas de Brás Cubas (1880), o narrador tenta subverter a convenção de escrita de (auto)biografias a partir do nascimento, mas neste caso, começa sua narrativa a partir do que chama de "nascimento metafísico". Este se deu no "Império do Brasil, no ano de 1809 "65, no momento em que conheceu D. Pedro, no bar da Corneta.

Na sequência desta dissertação, temos o romance de Ruy Castro, Era no Tempo do rei. Romance da Chegada da Corte, publicado em 2007. O autor nasceu em 1948 e atualmente trabalha como jornalista, tendo escrito algumas biografias e outros romances. O livro foi escrito como forma de homenagear Manuel Antônio de Almeida, utilizando a frase de abertura de Memórias de um sargento de milícias (1852-1853) como título, e também tomando dela emprestados alguns personagens, como o menino Leonardo, Vidigal, o compadre (padrinho de Leonardo) e Luisinha.

Na apresentação da obra, na “orelha de capa” é exposta a pesquisa que Ruy Castro fez para apresentar o Rio de Janeiro do século XIX, e também explora o entrecruzamento entre história e ficção:

\footnotetext{
${ }^{64}$ D. Pedro possui titulação diversa na América e na Europa: no Brasil é D. Pedro I e em Portugal é D. Pedro IV.

${ }^{65}$ José Roberto TORERO. Galantes memórias e admiráveis aventuras..., op.cit., p.59. O narrador faz uma pequena confusão, pois esta nomenclatura "Império do Brasil", surge após a Independência, em 1822.
} 
Em Era no tempo do rei, Ruy combinou as duas técnicas: a pesquisa em profundidade, para reconstituir o Rio do começo do século XIX, e a ficção burlesca e desvairada, em que personagens reais e imaginários se movimentam com tal precisão histórica que muitas vezes nos perguntamos se aquilo que estamos lendo aconteceu ou não. ${ }^{66}$.

Nota-se como é explorado o aspecto da pesquisa histórica e ficção combinados no romance, de forma a caracterizar o Rio de Janeiro do século XIX através da verossimilhança, o que poderia levar o leitor a interpretar a ficção como relato histórico. Assim, ao fim da apresentação, lê-se:

(...) Neste livro, o escritor pôde fazer aquilo a que nunca se permitiu em suas biografias: deixar a ficção correr solta. Só que em ambientes tão reais e com palavras tão mágicas que, em muitas páginas deste livro, a História e a literatura se abraçam e se beijam de forma quase imoral. ${ }^{67}$

Se utilizado como artifício para chamar a atenção do leitor e prendê-lo ao enredo da obra, não sabemos como este tipo de comentário é recebido pelo leitor, pois abre margem a muitas possibilidades de interpretação dessa obra. De toda forma, o entrecruzamento entre história e ficção são ressaltados para o leitor.

Na trama de Era no tempo do rei, acompanhamos as aventuras de Leonardo com o infante Pedro, no cenário urbano do Rio de Janeiro do século XIX. São feitas muitas menções e esclarecimentos acerca do período histórico que serão analisadas nos capítulos seguintes.

O romance Olhos Negros - O romance de $1817^{68}$, foi publicado pela primeira vez em 2009, pela editora Bagaço, de Recife. Esta obra possui menor circulação do que os demais aqui mencionados, não sendo encontrado facilmente no mercado. A revolução de Pernambuco de 1817 durou aproximadamente três meses, e significou para D. João uma ameaça à unidade do território luso-americano, sendo duramente reprimida pelo governo imperial português. Pernambuco desempenhava papel importante na produção e circulação de mercadorias e, às vésperas da revolução passava por forte crise de

\footnotetext{
${ }^{66}$ Apresentação do romance na "orelha de capa" do livro feita pelo editor. Em: Ruy CASTRO. Era no tempo do rei. Um romance da chegada da corte. Rio de Janeiro: Objetiva, 2007.

${ }^{67}$ Ruy CASTRO. Era no tempo do rei. Um romance da chegada da corte. Rio de Janeiro: Objetiva, 2007.

${ }^{68}$ Maria Cristina Cavalcanti de ALBUQUERQUE. Olhos Negros - O romance de 1817. Recife: Bagaço, $3^{\mathrm{a}}$ edição, 2017.
} 
abastecimento, além da imposição, pelo governo central imperial, de novos impostos recolhidos aos cofres reais do Rio de Janeiro, e de recrutamentos compulsórios. Em março de 1817, os revolucionários derrubaram o governo da província constituindo um novo, além de esboçar um projeto de Constituição própria. ${ }^{69}$

Olhos Negros possui construção distinta das outras obras. Em nota ao final do livro, sua autora pontua: "todos os personagens deste livro tiveram existência real, salvo Dona Maricotinha, a narradora". ${ }^{70}$ E esclarece que baseada na tradição oral, conta que o general José Inácio de Abreu e Lima teve um caso com uma mulher chamada Maricota. Com base nestas informações e consultando historiadores especializados na região (Tácito Luiz Cordeiro Galvão e Guilherme Jorge Paes Barretto Neto), criou a personagem ficcional.

A autora, Maria Cristina Cavalcanti de Albuquerque, é pernambucana, psiquiatra, historiadora e romancista. Foi ex-presidente e sócia efetiva do Instituto Arqueológico, Histórico e Geográfico Pernambucano. É estudiosa da história de Pernambuco e publicou outros romances $^{71}$. Na voz da narradora Maricotinha, é possível perceber a valorização do projeto autônomo da província, que ela entende como uma outra independência, a do "projeto republicano de Pernambuco".

Essa não é uma obra com intuito de satirizar a história da Independência, mas sim de apresentar um olhar que coloque em destaque Pernambuco e as revoltas que sediou em 1817 e 1824 (a Confederação do Equador). Este romance apresenta destaque sobre o processo de Independência a partir de Pernambuco. No livro também é citada de maneira mais superficial a Revolta dos Alfaiates (na Bahia), de 1798, a Revolução Constitucionalista do Porto, de 1820, e a Revolução Praieira,de 1842. Seu discurso não é linear, portanto ela não segue uma ordem cronológica sobre as revoltas: estas são contadas por Maricotinha a partir dos personagens e sua rede de sociabilidade, onde também é apresentado parte do passado deles.

A estrutura do livro e o modo como a narrativa foi construída confundem o leitor, numa série de idas e vindas cronológicas, entre o presente e as memórias passadas da narradora. Nessa obra desfilam muitos personagens históricos. Outro ponto que chama atenção é a linguagem: foram usadas categorias empregadas pelos historiadores

\footnotetext{
${ }^{69}$ João Paulo PIMENTA. A Independência do Brasil e a experiência hispano-americana..., op.cit, p.267274.

${ }^{70}$ Maria Cristina Cavalcanti de ALBUQUERQUE, op.cit.,2017.

${ }^{71}$ Informações retiradas do próprio livro. Maria Cristina Cavalcanti de ALBUQUERQUE, op.cit, 2017.
} 
referindo-se ao processo de Independência que, para um leitor comum, ficam confusas ou talvez sem significado, já que não são explicadas: por exemplo, "Direito Natural", "liberalismo democrático" e "pacto social". O livro estrutura-se em 10 capítulos, cada um com ênfase em um personagem histórico e pessoas ligadas a eles. A narrativa se passa em 1869, sendo Maricotinha a narradora, amante do general Abreu e Lima e tendo convivido com alguns dos revolucionários que participaram da revolução de Pernambuco em 1817. Maricotinha narra toda essa memória para o padre Lino. A narradora parece se confundir com a autora, pois essa narradora parece ser uma projeção da voz da autora camuflada por essa personagem, a único fictícia no romance.

A narradora destaca alguns personagens que correspondem aos respectivos capítulos do livro (aqui seguem-se de 1 a 10 na sequência): "O monsenhor", onde a narradora fala de seu protetor Muniz Tavares; “A mundana”, em que Maricotinha narra sua própria história frente aos episódios de 1817 em Pernambuco; "O amado", que referese ao padre João Ribeiro, aqui, o padrinho da narradora; "O amante", que relata a trajetória de seu amante José Inácio de Abreu e Lima; "O estadista”, onde o foco é sobre Gervásio Pires; "O poeta”, sobre José da Natividade Saldanha; "O herói”, que é Cipriano Barata; "O jornalista", Hypolito José da Costa; O médico, Manuel Arruda da Câmara; E “O general”, isto é, a trajetória política e militar de José Inácio de Abreu e Lima.

Este livro possui uma marca pedagógica para ensinar a história da revolução de Pernambuco e destacar sua importância na história nacional. Há uma crítica ao ensino da revolução de 1817. A narradora, Maricotinha, funcionando como uma máscara da autora, comenta sobre o ensino nas escolas e critica o destaque à figura de Frei Caneca e esquecimento de outros participantes da revolução de Pernambuco de 1817: "Observo que nossas crianças de escola esqueceram o nome dos padres João Ribeiro e do Vigário Tenório. Reverenciam o nome de Caneca, mas começaram a mitificar a figura de José de Barros Lima, o Leão Coroado"72

Outro livro que possui característica semelhante a Olhos Negros (2009), com uma intenção pedagógica e que dialoga diretamente com ele, é $A$ noiva da revolução: $O$ romance da República de $1817^{73}$, escrito por Paulo Santos de Oliveira e publicado em

\footnotetext{
${ }^{72}$ Maria Cristina Cavalcanti de ALBUQUERQUE. Olhos Negros - O romance de 1817.., op.cit, 2017, p.267.

${ }^{73}$ Paulo Santos de OLIVEIRA. A Noiva da Revolução: o romance da república de 1817. Recife: Associação Centro Vivo Recife, $4^{\mathrm{a}}$ edição, 2014. Este livro inspirou duas histórias em quadrinhos A noiva de Eron VILLAR \& Thony SILAS, lançada em 2017 e "1817, Amor e revolução de Pedro ZENIVAL. O livro inpirou também o filme A revolução esquecida de Tizuka YAMAZAKI, disponível em: https://www.youtube.com/watch?v=exAmzrVk8VE\&t=3551s
} 
2006. O livro também narra a história da denominada Revolução Pernambucana. O foco central são os personagens que participaram da revolução, e a narradora é Maria Teodora da Costa Martins Pires, personagem que existiu e foi casada com um dos líderes da Revolução de Pernambuco, Domingos José Martins. Nessa obra, a narradora encontra os escritos deixados por seu falecido marido sobre a Revolução de 1817 e resolve completálos. O material encontrado é similar a um diário da revolução, contendo anotações de Domingos José Martins, dia a dia. Maria Teodora, então, completa cada anotação com alguma explicação sobre os eventos, a sociedade da época, os personagens. Assim a narradora escreve o que o marido não pôde já que foi executado pela participação na revolução. Quando Maria Teodora narra a história já possui 57 anos, 40 anos depois dos eventos relatados. Temos, portanto, mais uma obra que apela ao uso de diários e memória. E há uma marca clara sobre os trechos “escritos por Domingos José Martins” e os trechos “escritos por Maria Teodora", sempre intercalados.

A narrativa centraliza os acontecimentos a partir do dia da eclosão da revolução em Pernambuco, ou seja, 06 de março de 1817, e se encerra quando os líderes são executados. O foco é a atuação dos líderes revolucionários em Pernambuco, seu projeto autônomo, e a adesão à revolução por outras províncias: Paraíba, Ceará, Rio Grande do Norte e Alagoas.

Por fim, temos o Cordel da história da Independência, uma publicação independente, de 2008, escrita por Luzimar Medeiros Braga $^{74}$. O autor nasceu em Nazarezinho, na Paraíba, em 20 de abril de 1941. Braga é economista, escreveu alguns romances e poesias, possui vários cordéis publicados ${ }^{75} \mathrm{e}$ é membro da Academia Brasileira de Literatura de Cordel $^{76}$.

No Brasil, a literatura de Cordel começou a ser produzida no final do século XIX. Sua produção pode ser considerada artesanal, sendo elaborada por uma camada rural da população da região Nordeste. Nessa região, a literatura de cordel alcançou maior desenvolvimento durante o século XX. ${ }^{77}$ De acordo com Márcia Abreu, a literatura de folhetos no Nordeste parece ter início no espaço de apresentação de poemas, cantorias e

\footnotetext{
${ }^{74}$ Luzimar Medeiros BRAGA. O cordel da história da Independência. Paraíba,(publicação independente), 2008.

75 Informações obtidas na página da Editora Alfa, que possui um breve perfil do escritor cordelista, e publicou $O$ Cordel do Manifesto Comunista de Luzimar Medeiros BRAGA. Acesso em 13/07/2019.

${ }^{76}$ Essa informação consta na capa de alguns dos seus cordéis que se encontram digitalizados na página Memórias da poesia popular: https://site.alfaomega.com.br/autores/medeiros-braga

77 Raymundo José da SILVA, Identidades e representações do Nordeste na Literatura de Cordel. Dissertação de Mestrado. Universidade Federal de Mato Grosso do Sul - Campus de Três Lagoas. Três Lagoas, 2008.
} 
desafios, marcados pela oralidade muito antes de se tornar possível a impressão em folhetos. ${ }^{78}$ A autora aponta que a forma impressa começou a ser produzida no final do século XIX mantendo forte marca de oralidade. ${ }^{79}$

Normalmente os folhetos eram vendidos em praças e feiras, sobretudo nos períodos de festas tradicionais como as festas juninas e de santos padroeiros. ${ }^{80}$ Dessa maneira, é possível perceber a característica principal do cordel, uma manifestação da cultura popular, advinda de tradições do Nordeste de matriz oral. Raymundo Silva, tomando como referência obras consagradas da literatura brasileira, aponta que a literatura de cordel jamais alcançou tal prestígio. Sobretudo porque "trata-se de uma literatura popular com fortes características folclóricas nordestinas, algumas de origem universal, direcionada a um tipo específico de leitor, com pouca instrução escolar e quase nenhum conhecimento das obras dos grandes escritores." $" 81$

Os folhetos de Cordel também eram conhecidos de outras formas "Livrinho de feira", "estória de meu padrim", "romance", ou "ABC" 82 . O ABC refere-se ao uso do folheto como cartilha de alfabetização. São muitos os temas observados na produção de cordéis, como aponta Raymundo Silva: "a fé, as superstições, as histórias de amor, a honra da família, a traição, a ambição, a valentia, ou a exaltação de personalidades da política." ${ }^{, 83}$ Podemos acrescentar, também, a história do Brasil.

Luzimar Medeiros Braga, o autor do Cordel da história da Independência, por exemplo, possui vasta produção de cordéis sobre política, história, personagens históricos ${ }^{84}$, intelectuais e escritores, como: A colonização da capitania da Paraíba; $A$ Era do feudalismo; A Guerra do Contestado; A Revolução Francesa; Anita Garibaldi: A heroína dos dois mundos; Ariano Suassuna; Arruda Câmara: O botânico e o politico; Capitalismo versus Democracia; Bertold Brecht: o poeta dos oprimidos em Cordel; Castro Alves: o poeta da liberdade; Chico Mendes. A morte anunciada; Carlos Marighella. Vida e morte em Cordel; Cordel ao educador Paulo Freire; Cordel Augusto dos Anjos; Cordel Che Guevara; Engels Na versão Agradável do Cordel; José Martí: o

\footnotetext{
${ }^{78}$ Márcia ABREU, Histórias de Cordeis e Folhetos. Campinas: Mercado de Letras: Associação de Leitura do Brasil, 1999, p.74.

${ }^{79}$ Ibidem, p.91.

${ }^{80}$ Raymundo José da SILVA, op.cit., p.41.

${ }^{81}$ Ibidem, p.42.

${ }^{82}$ Ibidem, p.44.

${ }^{83}$ Ibidem, p.45.

${ }^{84} \mathrm{Na}$ página da Internet Memórias da poesia popular é possível visualizar algumas das capas de córdeis produzidos por Luzimar Medeiros Braga, não há informações acerca do ano de produção de cada um dos cordéis, apenas as capas digitalizadas. Ver:https://memoriasdapoesiapopular.com.br/tag/luzimar-medeirosbraga/
} 
apóstolo da independência cubana; Simón Bolivar: o Libertador. Na versão Literatura de Cordel. Trazendo a participação de Abreu e Lima como general de seu exército; Tiradentes e a Inconfidência, dentre muitos outros, e inclusive temas recentes como o do cordel Vinte Centavos que Mudaram o Brasil. Na versão agradável do Cordel. ${ }^{85}$

Dessa maneira, é possível perceber uma característica pedagógica e instrutiva dos cordéis, além de entretenimento, como apontado anteriormente, em uma linguagem popular, de fácil entendimento e leitura breve. No que se refere aos cordéis escritos por Medeiros Braga, é ressaltado seu "trabalho educativo e de conscientização política do povo." $" 86$

No Cordel da história da Independência é possível perceber as concepções da Independência representadas, de questionamento e descrédito à Independência, além da valorização da participação popular e uma proposta de trabalho educativo para "conscientização/ Dessa gente brasileira." ${ }^{87}$ O Cordel da história da Independência, aqui analisado, trata do dito processo a partir da invasão de Napoleão Bonaparte à Portugal e subsequente transferência da Corte portuguesa para o Brasil. Também são abordadas as lutas pela Independência na $\mathrm{Bahia}^{88}$ e, em um recuo cronológico, a Inconfidência Mineira. Dessa forma, o Cordel apresenta uma interpretação do processo de Independência de maneira crítica, concebida em versos rimados.

Embora já tenha apontado alguns aspectos sobre concepções e tratamentos dispensados à história e à Independência nestas obras, uma análise propriamente dita das representações nelas encontradas será tratada a seguir. Assim, no capítulo que se segue, apresentarei como cada obra concebeu a Independência, se de maneira processual, ou enfatizando eventos, ou ainda apontando ênfases a determinadas regiões do país. Na sequência, no mesmo capítulo, é apresentada uma análise de conceitos que foram utilizados de maneira reiterada nos objetos analisados, demonstrado a importância para o tema da Independência.

\footnotetext{
${ }^{85} \mathrm{O}$ último cordel faz referência aos protestos que começaram contestando o aumento da passagem de ônibus em São Paulo, promovido pelo Movimento Passe Livre, porém ganharam outra dimensão e engajamento político se estendendo por manifestações em outros estados do Brasil e contestação de muitas causas e bandeiras políticas, em 2013. Tema de estudo, desde então, de muitos cientistas políticos e historiadores. A capa do cordel contém uma foto aérea de uma dessas grandes manifestações com a seguinte legenda na parte de cima: “O gigante acordou...e agora?" Na página Memórias da poesia popular : https://memoriasdapoesiapopular.com.br/tag/luzimar-medeiros-braga/

86 Informações retiradas do perfil do autor que consta na página da Editora Alfa Ômega. Site: https://site.alfaomega.com.br/autores/medeiros-braga

${ }^{87}$ Ibidem, p.20

${ }^{88}$ Luzimar Medeiros BRAGA, op.cit., , p.15-16.
} 


\section{Capítulo 1. A Independência na literatura brasileira}

\subsection{Linhas gerais de desenvolvimento e interpretação da Independência}

Quando tratamos sobre a Independência fenômeno que cria condições para que o Brasil se defina como Estado e nação soberanos, nos referimos a uma série de eventos que resultaram em sua separação política com relação a Portugal. Para além disso, também falamos de projetos de Brasil. Não é possível abordar a Independência sem ter em mente que no horizonte de expectativa dos sujeitos que participaram dos eventos a ela correspondentes no século XIX, havia ideias e propostas para a construção desse Estado e da nação. A formação da identidade coletiva dos brasileiros enquanto nação foi construída paulatinamente, consolidando-se anos após a Independência.

Neste capítulo apresentarei como a Independência do Brasil foi concebida nas produções literárias que integram os objetos analisados nesta pesquisa, ou seja, se a Independência é entendida como um processo ou são destacados apenas alguns episódios. Será apresentada a cronologia estabelecida nas obras, quais episódios são evidenciados e como é concebida a Independência: se é considerada revolucionária, pacífica ou "um acordo", por exemplo. Inicialmente, procederei a uma introdução sobre temas recorrentes na historiografia. Será possível perceber, adentrando na análise de conceitos que foram reiterados nas obras, como muitas das discussões historiográficas convergiram com as representações da Independência na literatura. Não à toa. Primeiramente, porque a Independência produz uma memória coletiva, que embora possua nuances regionais, variações e divergências, também possui muitas convergências, e a literatura não está alheia a essa memória. Há uma narrativa que poderia ser chamada, com os riscos de uma generalização excessiva, de "oficial", e que apresenta uma sequência de eventos preferencialmente políticos, traçando dessa forma o processo da Independência. Essa narrativa "oficial", que demarca festejos cívicos e lugares de memória, é abordada em manifestações culturais diversas, além de ser tema do ensino básico. Historiadores, escritores e praticamente todos os demais brasileiros - ao menos aqueles em condições de formular alguma ideia a respeito de sua história coletiva - estão imersos nessa mesma cultura de história e partilham dessa memória nacional. Portanto, é possível inferir que muitos estudos provêm de inquietações e discussões de seu tempo, que de forma sincrônica podem se refletir nas escritas literárias. Ou seja, debates que circulam em 
espaços de opinião pública e que ajudam a formular concepções sobre o processo de Independência do Brasil, num dado período, de uma forma que pode ser inconsciente, acabam sendo incorporadas nas representações elaboradas na literatura.

Sob viés diacrônico, a partir do momento em que certas concepções e modos de pensar aspectos da história da Independência se tornam muito estáveis, tradicionais, por mais que os estudos historiográficos avancem em direções diversas, essas formulações dificilmente ganham novo olhar, sendo apenas reiteradas no tempo.

Embora muito se questione sobre o alcance social da produção acadêmica de história no Brasil atual, foi possível perceber certas correspondências entre interpretações historiográficas sobre o tema e as representações elaboradas nas obras literárias, que refletem mesmo que de forma inconsciente, intertextualidades. Nessa cultura de história, leituras e leitores possuem uma grande importância na forma como irão receber, interpretar, engendrar o entendimento formulado - eventualmente reproduzido - de elementos do passado, e de alguma forma isso tem um retorno, tal qual um movimento em espiral e constante, já que os leitores podem contribuir nessa cultura de história, produzindo e reproduzindo representações da história. Essas contribuições podem partir de um vídeo de um trabalho sobre o tema de um aluno do ensino médio, que disponibiliza o conteúdo na Internet; ou através de um mediador cultural em uma exposição sobre a Independência ou de algum personagem correlato; também pelos professores nas escolas; ou por um leitor que se torne um escritor; ou ainda por produções cinematográficas baseadas em obras literárias, dentre muitas outras formas possíveis. Esse movimento não cessa, ele sempre retorna para a sociedade. Entretanto, pode sofrer alterações em seu caminho.

Após uma introdução das interpretações produzidas acerca da Independência do Brasil e de sua historiografia, será apresentado como a Independência aparece nas obras literárias, a cronologia de cada uma delas, os eventos destacados, as possíveis ênfases de regiões do Brasil nas representações contidas em cada obra. Em seguida serão analisados conceitos que foram utilizados de forma reiterada nas representações da Independência dos objetos aqui analisados: "despotismo"; "anarquia"; "revolução"; "pátria" e "nação"; "liberdade" e "liberalismo". Interessa nessa análise apresentar como cada conceito foi empregado, que sentido ganhou ao longo do tempo, e nesse aspecto, sua correspondência ou não com a historiografia do tema. Ou seja, pretende-se analisar o que foi feito da história da Independência do Brasil, nas representações encontradas na literatura e possíveis correspondências com interpretações de estudos historiográficos. 
Uma possibilidade de análise referendada pela historiografia, diz respeito à periodização dos acontecimentos. Por exemplo, o fator que inaugura a série de eventos que resultam na Independência do Brasil, com a invasão de Napoleão Bonaparte a Portugal. A invasão ocorreu pois Portugal desobedeceu o embargo imposto por Napoleão aos países continentais. Possuindo a Grã-Bretanha como aliada, Portugal encontrou como alternativa a transferência da Família Real e a Corte para o Brasil, com a escolta britânica.

Com a chegada da Corte ao Brasil em 1808 ocorreram diversas transformações estruturais e sociais no território, além de alterações na política, na economia, e na cultura da América lusitana. Em 1808 ocorre a abertura dos portos do Brasil às nações amigas. Em abril do mesmo ano foi abolida a proibição de instalação de fábricas no Brasil ${ }^{89}$. Em junho foi fundado o Museu Real ${ }^{90}$ e também a Imprensa Régia no Rio de Janeiro, a última com início das atividades em $1809^{91}$. Em outubro de 1808 foi criado o Banco do Brasil, com início das atividades no ano seguinte. Em fevereiro de 1809, D. Rodrigo de Sousa Coutinho assinou alvará estabelecendo um sistema de comércio entre o Atlântico e o Índico, abolindo os entraves para importação direta de artigos asiáticos ${ }^{92}$. Em maio, foi criado o Corpo da Guarda Real de Polícia da Corte ${ }^{93}$. Em 1810 é instalada a Real Biblioteca do Rio de Janeiro ${ }^{94}$. No mesmo ano o Real Teatro de São João é criado no Rio de Janeiro ${ }^{95}$. Em março de 1811 foi fundado o Jardim Botânico do Rio de Janeiro. ${ }^{96}$ Em 1815, o Brasil foi elevado a Reino Unido a Portugal e Algarves.

Em 1817, como vimos anteriormente, ocorreu a revolução de Pernambuco devido às insatisfações locais em relação ao estrangulamento econômico que a província sofria, por conta de uma crise na produção de algodão e açúcar, além do descontentamento com os impostos recolhidos em benefício dos cofres reais no Rio de Janeiro e com o recrutamento forçado para tropas realistas. Por cerca de três meses a província se tornou autônoma, com um governo próprio e elaborando um projeto republicano, sendo o

\footnotetext{
89 Andréa SLEMIAN; Ariane Cristina MARTINS; João Paulo Garrido PIMENTA; WISIAK, Thomas WISIAK, István JANCSÓ (orientação), Cronologia de História do Brasil Colonial (1500-1831).São Paulo: FFLCH-USP, 1994.

${ }^{90}$ Ibidem, 1994.

${ }^{91}$ Ibidem, 1994.

92 Ana Cristina ARAÚJO, "Um Império, um reino e uma monarquia na América: as vésperas da independência do Brasil”. In: István JANCSÓ (org.), Independência: História e historiografia. São Paulo: Fapesp: Hucitec, 2005, p.235-270.

93 André R.A.MACHADO; Carlos A.C.GANDRA JR.; Eric R.G.ZEN; Fernanda SPÓSITO; Renata I. C.CONSEGLIERE. István JANCSÓ (orientação). Cronologia de História do Brasil Monárquico (18081889). São Paulo: Humanitas/ FFLCH/USP,2000.

94 Andréa SLEMIAN [et.al.], op.cit., 1994.

${ }^{95}$ André R.A.MACHADO [et.al.], 2000.

96 Andréa SLEMIAN [et.al.], op.cit., 1994.
} 
movimento sufocado por repressão comandada a partir da Bahia, pelo seu governador, o Conde dos Arcos, recorrendo a punição violenta dos revolucionários, com a execução pública de seus líderes. Mais de trezentas pessoas foram formalmente acusadas na devassa que se encerrou em fevereiro de $1818 .^{97}$

Com a deflagração da revolução do Porto em 1820 e a convocação das Cortes em Lisboa foi exigido o retorno do monarca a Portugal. Em 1821, D. João VI e a Família Real retornam a Portugal, mas D. Pedro permaneceu no Brasil como príncipe regente. Ocorreu então, no final do mesmo ano, a exigência de retorno de D. Pedro. Todavia sua decisão de permanecer no Brasil foi formalizada em 9 de janeiro de 1822, no evento que ficou conhecido como "Fico". Alguns meses depois, em maio, D. Pedro recebeu o título de Defensor Perpétuo do Brasil. Em setembro foi declarada a Independência. Em 12 outubro do mesmo ano, data de seu aniversário, D. Pedro foi aclamado Imperador do Brasil. Finalmente em dezembro de 1822 ocorreu a cerimônia de coroação de D. Pedro I. Entretanto, a Bahia permaneceu em guerra ${ }^{98}$, inicialmente por conta da indicação do general português para o comando das Armas da província Ignácio Luiz Madeira de Mello, depondo Manoel Pedro de Freitas Guimarães. Com a declaração da Independência no centro-sul, ocorreu, na província baiense, uma divisão entre os que apoiavam a adesão à constituição elaborada em Portugal e o grupo que defendia a emancipação brasileira, apoiando D. Pedro I. A guerra se estendeu até 1823, quando as tropas lusas foram derrotadas e expulsas de Salvador em 2 julho. Em maio do mesmo ano tiveram início os trabalhos da primeira Assembléia Constituinte e Legislativa brasileira, sendo dissolvida em novembro de 1823 pelo Imperador. Em 25 de março de 1824 é outorgada a primeira Constituição do Brasil, produzida por um conselho nomeado pelo imperador em detrimento da Constituinte dissolvida. Em 7 de abril de 1831 D. Pedro abdicou do trono em favor de seu filho, ainda infante. ${ }^{99}$

\footnotetext{
97 João Paulo PIMENTA, A Independência do Brasil e a experiência Hispano-americana. (1808-1822). São Paulo: Hucitec: Fapesp, 2015, p. 273-274. Sobre a revolução pernambucana ver também: Evaldo Cabral de MELLO. A outra independência: o federalismo pernambucano de 1817 a 1824 . São Paulo: Editora 34, 2014; Denis Antônio de Mendonça BERNARDES. O Patriotismo Constitucional: Pernambuco, 1820-1822. Tese de Doutorado. Faculdade de Filosofia, Letras e Ciências Humanas (USP), São Paulo, 2001.; Carlos Guilherme MOTA. Nordeste 1817: Estruturas e Argumentos. São Paulo: Perspectiva, 1972; Márcia Regina BERBEL. "Pátria e patriotas em Pernambuco (1817-1822): Nação, identidade e vocabulário político. In: Jancsó, István. (Org.). Brasil: formação do Estado e da nação. São Paulo: EDUSP: Hucitec, 2003, p.345-363.

98 As guerras de Independência no Maranhão, Pará e Piauí só tiveram fim em 1823. Em outubro de 1823 ocorre a expulsão das tropas lusas da Banda oriental. Em: André R.A.MACHADO [et.al.], 2000.

99 Sobre a Independência ver, dentre muitos: Francisco de Adolfo VARNHAGEN, História da independência do Brasil. Rio de Janeiro: Instituto Histórico e Geográfico Brasileiro, 1916; Nelson Werneck SODRÉ, As razões da independência. Rio de Janeiro: Civilização Brasileira, 1969; Manuel de Oliveira
} 
Esses são alguns eventos que compõem a cronologia do processo de Independência do Brasil. O destaque para as lutas ocorridas em Pernambuco e Bahia, em geral, é menor do que os eventos ocorridos no centro-sul do Brasil, projetando ênfase em torno de Rio de Janeiro e São Paulo, e na atuação do príncipe regente e seus conselheiros. $\mathrm{Na}$ historiografia são discutidas algumas interpretações sobre o processo de Independência, e aqui apresento algumas dessas vertentes com base na análise de Wilma Peres da $\operatorname{Costa}^{100}$, sobre as permanências e rupturas que ocorreram e são defendidas por distintas linhas de estudos.

A vinda da Corte para o Brasil e as transformações econômicas e políticas que ocorreram a partir daí, como a já citada abertura dos portos para as nações amigas e a elevação do Brasil a Reino, marcam a crise do Antigo Regime. O estabelecimento da Corte na colônia significou que o centro de decisões do Reino Português não se encontrava mais na metrópole e sim na colônia. Entretanto, nesse processo a colônia alcançou maior autonomia econômica e política. A crise foi deflagrada com a Revolução do Porto, que teve início em 24 de agosto de 1820, a partir de um movimento iniciado por um grupo composto por comerciantes, militares, funcionários do Estado, profissionais liberais e aristocratas, cujo intuito era instaurar o Regime Constitucional no Reino Unido

LIMA, O movimento de independência,1821-1822. São Paulo: Melhoramentos, 1972; A obra dividida em 5 volumes: José Honório RODRIGUES, Independência: revolução e contra-revolução. São Paulo: Editora da Universidade de São Paulo, 1975; Carlos Guilherme MOTA, 1822: Dimensões. São Paulo : Perspectiva, 1986; Sérgio Buarque de HOLANDA, “A herança colonial-sua desagregação”. In: História Geral da civilização brasileira, tomo II: O Brasil Monárquico. Rio de Janeiro: Bertrand Brasil S. A, p.09-39, 1993; István JANCSÓ e João Paulo Garrido PIMENTA, "Peças de um mosaico (ou apontamentos para o estudo da emergência da identidade nacional brasileira)". In: MOTA, Carlos G (org.). Viagem incompleta: a experiência brasileira 1500-2000. São Paulo: Senac, 2000; João Paulo PIMENTA. "A independência do Brasil como uma revolução: história e atualidade de um tema clássico". In: História da Historiografia, v. 3, p. 53-82, 2009; Keila GRIMBERG \& Ricardo SALLES, O Brasil imperial: 1808-1831, volume I. Rio de Janeiro: Civilização Brasileira, 2010. Além destas ver também: Caio PRADO JÚNIOR, Evolução política do Brasil: colônia e império. São Paulo: Brasiliense, 1988; Caio PRADO JÚNIOR, Formação do Brasil Contemporâneo. São Paulo : Brasiliense, 1994; Ilmar Rohloff de MATTOS. O tempo saquarema. Rio de Janeiro: Access Editora, 1999; Wilma Peres COSTA, "A independência na historiografia brasileira”, in: István JANCSÓ (org.), Independência: História e historiografia. São Paulo: Fapesp: Hucitec, 2000, p.53-118; István JANCSÓ, Independência: História e historiografia, In; Jancsó, István (org.), São Paulo: Fapesp: Hucitec, 2000; Maria Odila Leite da Silva DIAS. A interiorização da metrópole e outros estudos. São Paulo : Alameda, 2005; Fernando Antônio NOVAIS. Portugal e Brasil na crise do Antigo Sistema colonial (1777-1808). São Paulo: Hucitec, 2005; Jurandir MALERBA(org.). A Independência Brasileira - Novas Dimensões. Rio de Janeiro: Editora FGV,2006; Celso FURTADO. Formação econômica do Brasil. São Paulo: Companhia das Letras, 2007; João Paulo G. PIMENTA, “A Independência do Brasil e o liberalismo português: um balanço da produção acadêmica".In: HIb: Revista de Historia Iberoamericana, v. 1", 2008; João Paulo PIMENTA, A Independência do Brasil e a experiência Hispano-americana. (18081822). São Paulo: Hucitec: Fapesp, 2015; João Paulo G. PIMENTA, Tempos e espaços das Independências: a inserção do Brasil no mundo ocidental (1780-1830). São Paulo: Intermeios: USP - Programa de Pós Graduação em História Social, 2017.

${ }^{100}$ Wilma Peres COSTA. "A Independência na historiografia brasileira”. In: JANCSÓ, István (org.). Independência: História e historiografia. São Paulo: Fapesp: Hucitec, 2005, p.56-57. 
Português. ${ }^{101}$ A convocação das Cortes Constituintes e a exigência de retorno do monarca acarretava uma busca, por parte de portugueses europeus, do retorno do centro das decisões políticas e do poder assentado em Portugal. As Cortes Gerais, Extraordinárias e Constituintes da Nação Portuguesa iniciaram os trabalhos em 26 de janeiro de 1821. Devido a demora da chegada de notícias, convocação e eleição dos representantes das províncias do Brasil a primeira bancada de deputados - de Pernambuco - chegou para participação nas Cortes somente em 29 de agosto de 1821. Em seguida chegaram os deputados representantes das províncias do Rio de Janeiro, Maranhão, Bahia e São Paulo. ${ }^{102}$

Assim, gradativamente foi se estabelecendo de um lado, a defesa do protagonismo de Portugal, e do outro, a defesa dos interesses e autonomia do Brasil (parte do Reino Unido de Portugal). Essa tensão nas Cortes desencadeou o medo e a teoria da recolonização do Brasil ${ }^{103}$, que seria o retorno deste ao status de colônia, servindo apenas aos benefícios econômicos e políticos de Portugal ${ }^{104}$.

Essa concepção da recolonização foi muito difundida e encontrada com constância nos poemas épicos ${ }^{105}$ aqui analisados, obras escritas e publicadas ainda no século XIX. Aliás, o papel da convocação das Cortes e o suposto despotismo ${ }^{106}$ português perante o Brasil e seus deputados aparecem de forma massiva nesses poemas.

Também se discutiu na historiografia sobre a forma como se desenrolou a Independência: uma negociação feita pela elite, um acordo, resultando numa "transição

\footnotetext{
101 João Paulo PIMENTA, A Independência do Brasil e a experiência Hispano-americana (1808-1822). São Paulo: Hucitec: Fapesp, 2015, p.356-357.

102 Ibidem, p.388-389. De acordo com Pimenta, os deputados de Minas Gerais e o único representante da província Cisplatina, não chegaram a tomar assento. (p.389)

${ }^{103}$ A suposta intenção de "recolonização" por parte de Portugal foi retórica muito utilizada no período, levantada nos debates das Cortes Constituintes em Portugal, em 1820. Esse argumento adentrou o espaço de opinião pública e foi divulgado e debatido em periódicos do período. Segundo Antonio Penalves, essa retórica foi elevada a fato histórico pela historiografia, sendo reafirmada ao longo do século XIX e XX. Ver: Antonio Penalves ROCHA, A recolonização do Brasil pelas Cortes: história de uma invenção. São Paulo: UNESP, 2009. Sobre a disseminação da "teoria" da recolonização do Brasil pelas Cortes em periódicos ver: Rafael FANNI, Temporalização dos discursos políticos no processo de Independência do Brasil (1820-1822). Dissertação de Mestrado. Faculdade de Filosofia, Letras e Ciências Humanas da Universidade de São Paulo. São Paulo, 2015.

104 Discorreremos mais detalhadamente adiante quando analisamos o conceito "despotismo" que foi vinculado à retórica da recolonização.

${ }^{105}$ Antonio Gonsalves TEIXEIRA E SOUSA,op.cit., Tomo I e II, 1847 e 1855; Ladislau dos Santos TITARA, op.cit, 1973.

106 Alguns conceitos que aparecem com certa constância nas fontes serão analisados de forma detida adiante.
} 
pacífica"107. Essa interpretação é especialmente relevante aqui, pois no artigo em que foi apresentada a pesquisa da qual esta é tributária ${ }^{108}$, de acordo com as entrevistas colhidas para entender como o brasileiro pensava a história e a história da Independência ${ }^{109}$, a palavra "revolução" foi pouco relacionada com a Independência. A partir da sondagem de opinião com o público não especializado, conforme um senso comum, foi possível entender, que as guerras travadas no Brasil mas que não envolveram a totalidade do território de forma unitária, não são consideradas revolucionárias. Essa concepção toma como exemplos de comparação os processos de independência dos países da América Hispânica que tiveram lutas violentas.

Vertentes da historiografia discutem sobre a atuação do monarca no processo de Independência. Alguns estudiosos destacam a atuação de D. Pedro como o fator que permitiu a unidade do território e o alcance da Independência. Caso de Francisco Adolfo de Varnhagen ${ }^{110}$, como destaca Wilma Peres Costa: “[...] o apoio do herdeiro legítimo do trono ao projeto emancipador emergia como diretamente responsável pelo sucesso da empreitada e pela manutenção da unidade territorial e política do Brasil" ${ }^{111}$. Por vincularse ao IHGB, tendo o patrocínio da Coroa e possuindo uma perspectiva diplomática, a interpretação de Varnhagen é identificada com uma visão conservadora, de acordo com a autora, que ainda ressalta que essa "atribuição, de resto indiscutível, não deve obscurecer o caráter militante e identitário de sua obra em seu esforço por estabelecer uma ligação entre o passado, o presente e o futuro da nação." 112 Sérgio Buarque, em 1960, apontava que a Independência só foi alcançada quando o monarca português se afastou do poder no Brasil, ou seja, com a abdicação de D. Pedro I em 7 de abril de 1831, pois foi "a partir

\footnotetext{
${ }^{107}$ Cecília Helena de Salles OLIVEIRA, "A astúcia liberal. Relações de mercado e projetos políticos no Rio de Janeiro (1820-1824). Bragança Paulista: Edusf-Ícone, 1999, p.59. Cit. In: Wilma Peres COSTA, op.cit, p.56.

${ }_{108}$ João Paulo PIMENTA; César Augusto ATTI; Sheila Virginia CASTRO; Nadiesda DIMAMBRO; Beatriz Duarte LANNA; Marina PUPO; Luís Otávio VIEIRA; "A Independência e uma cultura de história no Brasil". In: Almanack, Guarulhos, n.08, p.5-36, $2^{\circ}$ semestre de 2014.

${ }^{109} \mathrm{Na}$ pesquisa sobre a cultura de história, procedemos a sondagem de opinião pública para entender o que o brasileiro pensava sobre a história e mais especificamente, a história da Independência do Brasil. Foram feitas 311 entrevistas em São Paulo. Para mais detalhes ver: João Paulo PIMENTA [et.al.], op. cit.,2014.

110 Francisco Adolfo de Varnhagen publicou História Geral do Brasil em 1854, e a História da Independência do Brasil foi publicada postumamente, em 1916. Em: Wilma Peres COSTA, op.cit., p.5660. As obras de varnhagen são: Francisco Adolfo de VARNHAGEN, História Geral do Brasil. Vol.I, Rio de Janeiro: Laemmert, 1854. E: Francisco Adolfo de VARNHAGEN: História da Independência do Brasil. Rio de Janeiro: Instituto Histórico e Geográfico Brasileiro, 1916.

${ }^{111}$ Wilma Peres COSTA, op. cit., p.58.

${ }^{112}$ Ibidem, p.60.
} 
de então que o ato de Independência ganhou verdadeiramente um selo nacional." 113 Wilma Peres esclarece que para Sergio Buarque a Independência marcava o início de uma "lenta desagregação da unidade" nacional que só se completaria "por volta de 1848". 114

Por um lado parte da historiografia exaltava a semente da nação na colonização portuguesa, na atuação e permanência da monarquia após a declaração da Independência, como a visão de Varnhagen ${ }^{115}$ (concepção que se liga muito a uma versão da memória da Independência que destaca a atuação central de D. Pedro, alçado a herói libertador da nação brasileira). Essa explicação e projeção da Independência na monarquia portuguesa, com o suposto "herói nacional" que lutou pela união das províncias em torno da causa comum da liberdade da nação brasileira, contra o "despotismo português" aparece de forma muito forte e evidente no poema épico da Independência de Teixeira e Sousa (1847 e 1855).

Por outro lado, algumas interpretações sobre o processo de Independência denunciam as continuidades como negativas e nocivas para a nação, como a permanência de um monarca português no trono e da escravidão ${ }^{116}$. As lutas regionais contra o domínio português ganhavam destaque (supostas fontes de projetos republicanos em começos do século XIX), assim como a queda do monarca que, em 1831, consolidaria a Independência ${ }^{117}$.

Muito se discutiu em torno das especificidades do caso brasileiro em contraposição ao processo de independências na América hispânica. João Paulo Pimenta ressalta a "influência e os desdobramentos, na independência do Brasil, das lutas de independência e da criação de Estados nacionais (majoritariamente repúblicas) na América espanhola do primeiro quartel do século XIX". ${ }^{118}$ Segundo o autor, "as transformações políticas em curso na América espanhola durante a crise e dissolução do Antigo Regime constituíram um espaço de experiência para o modelo político luso-

\footnotetext{
113 Sérgio Buarque de HOLANDA. "A herança colonial - sua desagregação". In: HOLANDA, Sérgio Buarque (direção), História Geral da civilização brasileira- O Brasil Monárquico, Tomo II. São Paulo: Difusão Europeia do livro, 1970, p.9-39.

${ }_{114}$ Wilma Peres COSTA, op.cit., p.83-84.

115 Varnhagen enaltece a obra civilizadora da monarquia portuguesa no Brasil, e destaca a atuação de D. Pedro na manutenção da unidade do território brasileiro e Independência. Em: Wilma Peres COSTA, op. cit., p.57-59.

${ }^{116}$ De acordo com Wilma Peres Costa, essa concepção identifica o "passado como fardo" e foi levada como "mote dos liberais", a exemplo de: Aureliano Cândido Tavares BASTOS. Os males do presente e as esperanças do futuro. São Paulo-Rio de Janeiro: Nacional 1939. Em: Wilma Peres COSTA, op.cit., p.6064.

117 Wilma Peres COSTA,op.cit., p. 64

${ }^{118}$ PIMENTA, João Paulo Garrido. A independência do Brasil e a experiência hispano-americana (18081822). São Paulo: Hucitec : Fapesp, 2015, p.24.
} 
americano, em grande medida responsável pelas condições gerais de projeção e consecução de horizontes de expectativa na América portuguesa, dos quais resultou um Brasil independente de Portugal, nacional, soberano, monárquico e escravista". ${ }^{119}$ Pimenta trabalha com a tese de um espaço de experiência revolucionário moderno comum, na América Ibérica, e não isolando ou ressaltando uma excepcionalidade no processo de independência brasileiro, percebe um espaço de trocas e aproximações no contexto revolucionário de formação dos nascentes Estados nacionais, envolvendo tanto a América portuguesa quanto a espanhola ${ }^{120}$.

Portanto, o processo histórico de formação do Brasil a partir de sua Independência deixa legados à posteridade. É interessante perceber como essas muitas questões (atuação da monarquia portuguesa para alcance da Independência; valor das lutas regionais no processo de Independência; os legados e discussões em torno de um horizonte de expectativa a partir da Independência; a conformação de uma identidade comum dos brasileiros, apenas citando alguns exemplos), aparecem nas obras literárias aqui analisadas. Não significa que todos estes elementos apareçam em todas as obras, mas a partir da análise de conjunto destaco como cada um deles foi abordado, ressaltando que o que está colocado na literatura não se liga necessária e diretamente aos estudos historiográficos. Mas como através dessa cultura de história na qual todos nós brasileiros estamos imersos, as discussões e problematizações levantadas na historiografia de alguma forma também podem se conectar com a literatura.

Em Primícias (1900), de Joaquim Gil Pinheiro, devido à amplitude da obra, que começa no século XVI apresentando primeiramente os povos originários do Brasil e seus costumes, o contato com os portugueses e no canto VII o escritor trata "Da descoberta do Brasil por Pedro Álvares Cabral" "121, é possível perceber uma abordagem da Independência que pode ser entendida como processual, neste caso, a partir da Inconfidência Mineira ${ }^{122}$. Já a partir do primeiro verso da parte que a aborda, o poeta

\footnotetext{
119 Ibidem, p.31.

${ }^{120}$ João Paulo Garrido PIMENTA. Tempos e espaços das independências: a inserção do Brasil no mundo ocidental (c.1780-c.1830). Tese de livre docência defendida na Faculdade de Filosofia, Letras e Ciências Humanas da Universidade de São Paulo. São Paulo, 2012, p. 4-12.

${ }^{121}$ Este é o título do Canto VII. In: Joaquim Gil PINHEIRO, op.cit., 1900. As concepções de costumes e representações dos indígenas parte do olhar de um português (o autor) e que visava enaltecer os "grandes feitos portugueses".

${ }^{122}$ Como consta no poema sob o subtítulo “Conspiração de Tiradentes em Minas Gerais (1789)”. Joaquim Gil PINHEIRO, op.cit, p.173.
} 
destaca: "Já nos fins do anterior século havia/ Planos da independência do Brasil;/ A liberdade já o povo a q'ria;/ Ainda que a maioria a achasse hostil". ${ }^{123}$

É interessante observar que, de acordo com o verso, não se tratava da liberdade da província - como prefere unanimemente a historiografia acadêmica das últimas décadas - mas planos para a independência do Brasil. Na sequência da Inconfidência Mineira (1789), já é abordada a vinda da Família Real e as mudanças que o Brasil sofreu. Mas na cronologia estabelecida nessa obra, são exploradas também a invasão da colônia francesa de Cayena por tropas portuguesas ${ }^{124}$; as lutas pela Província Cisplatina ${ }^{125}$; a Revolução Pernambucana ${ }^{126}$; as Cortes de Lisboa; o dia do Fico; a aclamação de D.Pedro "defensor perpétuo"; o grito do Ipiranga e a aclamação de D. Pedro "Imperador perpétuo". O poema termina com a aclamação pois, justifica o poeta, D. Pedro fez-se trovador do período colonial para exaltar as glórias de Portugal. ${ }^{127}$ Nessa cronologia vemos, portanto, além dos eventos que ocorreram no Rio de Janeiro e São Paulo, que demarcam o grito da Independência, a Inconfidência Mineira, a Revolução de Pernambuco de 1817, e as lutas em torno da província Cisplatina.

Sobre o que teria levado o Brasil à Independência, algumas passagens esclarecem o posicionamento do poeta, e a análise aqui inclui tanto os versos do poema como as notas com dados históricos (o paratexto):

P'ra o reino não cuidava de voltar / Causando desconfiança à lusa gente;/ Parecia-lhe ter ainda o que recear, / Porque saíra de lá covardemente.

Por causa disto o Porto se agitou, / Lançando um manifesto assaz hostil; / O qual dizia que El-Rei o país logrou, / Co’ abertura dos portos do Brasil $^{128}$

Na nota do primeiro verso o poeta acrescenta que: "D. João tinha grande predileção pelo Brasil, no qual executou grandes e valiosos melhoramentos, apressando com eles a sua independência" ${ }^{129}$. Sabe-se que com a derrota de Napoleão, muito se questionou sobre a

\footnotetext{
123 Joaquim Gil PINHEIRO, op.cit., P.173.

${ }^{124}$ Ibidem, p. 182.

${ }^{125} \mathrm{O}$ poeta se refere ao Uruguai, e movimento das tropas portuguesas em Salto de Uruguay, Maldonado, Carumbé, Índia Morta, Catalão, Montevideo, Missões, a colônia de Sacramento, Passo de Taquarembó, definindo depois o nome de Província Cisplatina. Joaquim Gil PINHEIRO, op.cit, p.184-186.

126 Joaquim Gil PINHEIRO, op.cit., p.186-192.

${ }^{127}$ Ibidem, op.cit., p.202.

128 Joaquim Gil PINHEIRO, op.cit., p.192.

${ }^{129}$ Nota do verso DIV. Em: Joaquim Gil PINHEIRO, op. cit., p.192.
} 
permanência de D. João e da Família Real no Brasil, visto que o motivo de sua transferência havia sido a invasão francesa à Portugal já remediada. No poema, a saída de Portugal de D. João e sua Corte é apontada de maneira pejorativa como covardia, e na nota seguinte, em que o autor explica sobre as queixas dos líderes da Revolução do Porto, acrescenta que alegavam que o atraso em que Portugal supostamente se achava foi causado pela ausência do monarca e pelas medidas comerciais em benefício da excolônia, que teriam arruinado o comércio e a indústria de Portugal. Assim, é possível depreender que a transferência dos monarcas e Família Real para o Brasil, não apenas proporcionou as condições de melhorias na colônia como potencializaram sua Independência e foram as responsáveis pela ruína de Portugal. E ainda, de acordo com a nota do poema acima citada, as melhorias implementadas no Brasil foram executadas devido a uma "preferência" de D. João pelo Brasil em detrimento de Portugal, e não pelo estabelecimento de condições para melhor acomodação da Família Real na colônia, sua nova morada. Nesse caso, percebe-se uma oposição Brasil versus Portugal. ${ }^{130}$

Destaco ainda dois versos:

Apenas com algumas agressões,/ Foi feita do Brasil a independência,/ Causando o patriotismo turbações/ Aos dois povos por essa divergência.

A rebelião em três partes se ateou ${ }^{131}$, / O mais se fez em paz segundo eu li: / Dom João nem forças para cá mandou / Porque havia combinado tudo aqui. ${ }^{132}$

Ainda que o autor trate da Inconfidência Mineira, da Revolução de Pernambuco de 1817, da guerra da independência na Bahia, e também dos "motins" do Maranhão, Pará e Cisplatina ${ }^{133}$, como estes não representam a totalidade do território são tratados como "algumas agressões", apontando que a Independência foi relativamente pacífica, e ocorreu através de um acordo. Como já destacado no começo deste capítulo, essa

\footnotetext{
${ }^{130}$ No penúltimo verso (DLII) o poeta destaca que narrou apenas o período colonial pois sua intenção era exaltar as glórias de Portugal, como já havia destacado no Prefácio. ("Desculpai-me, prezado e bom leitor,/ Em só narrar a parte colonial;/ Deste período fiz-me trovador, Para as glórias exaltar a Portugal.") In: Joaquim Gil PINHEIRO, op.cit, p.202.

${ }^{131}$ As rebeliões a que se refere o verso ocorreram no Maranhão, Pará e Cisplatina, conforme nota do autor. In: Joaquim Gil PINHEIRO, op.cit., p.202.

${ }^{132}$ Ibidem, p.201-202.

${ }^{133}$ Conforme o verso "A rebelião em três partes se ateou" e nas informações das notas explicativas em rodapé do poema, o poeta refere-se a "motins provocados pelas forças brasileiras, que entusiasmadas com a independência, exigiam que as autoridades portuguesas se demitissem sem que recebessem ordem do poder legal, querendo obrigá-las a embarcar para o reino.”Em: Joaquim Gil PINHEIRO, op.cit., p.202.
} 
interpretação da Independência feita através de uma negociação, de forma pacífica, com o protagonismo da Família Real, também foi muito recorrente na historiografia, e o é ainda hoje na cultura de história brasileira, fazendo parte de um senso comum de parte da população $^{134}$.

Embora a obra de Teixeira e Sousa seja intitulada Poema Épico da Independência do Brasil em XII Cantos (1847 e 1855), e narre os feitos e trajetória do herói (D. Pedro), o canto II do Tomo I discorre de modo mais superficial sobre a ocupação da América (em sua totalidade) e independências das colônias nela estabelecidas ${ }^{135}$. No poema, na passagem em que D. Pedro encontra dois viajantes e a pedido deles narra os recentes sucessos do Brasil, começa pela Revolução Francesa, seguindo com a "vinda da Rainha de Portugal para o Brasil" ${ }^{136}$. Consta ainda na epopeia a Revolução Pernambucana ${ }^{137}$; os debates das Cortes de Lisboa e discursos de Lino Coutinho, Cipriano Barata e José Bonifácio de Andrada, deputados representantes de províncias do Brasil ${ }^{138}$; levantes das juntas nas províncias e lutas na Bahia contra o general Madeira e as tropas portuguesas; e o grito do Ipiranga. Em nota do final do poema, o autor transcreveu cópia do discurso que o conselheiro José Clemente Pereira proferiu no dia da aclamação de D. Pedro no Rio de Janeiro. ${ }^{139}$

Assim, a Independência é apresentada de maneira processual, e há uma conexão com os exemplos das independências das colônias espanholas ${ }^{140}$. É possível perceber a efervescência de revoltas nesse processo, espalhados pelo território, fugindo, portanto, de

\footnotetext{
${ }^{134}$ Conforme verificado nas entrevistas de opinião pública colhidas na pesquisa apresentada no artigo: João Paulo PIMENTA [et.al.], 2014, p.11-18. Em outro artigo João Paulo Pimenta e Mariana F. Paulino esboçam uma análise acerca da consideração da Independência como uma revolução e diagnosticam uma "interdição" por parte da historiografia, que pautou uma interpretação que se consolidou como uma tradição: uma "recusa" do brasileiro em reconhecer seu passado como conflitivo, o entendendo como negociado, conservador. Em: João Paulo PIMENTA \& Mariana Ferraz PAULINO, "Uma revolução interditada: Esboço de uma genealogia da ideia de "não-independência" do Brasil". In: Rogelio ALTEZ \& Manuel CHUST (orgs.). Las revoluciones en el largo siglo XIX Latinoamericano. Madrid: AHILA: Iberoamericana: Vervuert, 2015, p. 151-169.

${ }^{135}$ Antonio G. TEIXEIRA e SOUSA, op.cit, Tomo I, p.47-107. Os países citados são: Estados Unidos da América; México; Grandes Antilhas (Guanahani, Cuba, Haiti e Jamaica); Pequenas Antilhas; Colômbia; Venezuela; Cundinamarca; Quito; Guianas; Peru; Bolívia; Chile; Arauco; Patagônia; Buenos Aires (ou Reunião do Prata); Uruguai; Paraguai. Aqui na descrição preservei os nomes da forma como qual o autor as apresentou em seu "Argumento" do Canto II.

${ }^{136}$ No poema é utilizada a expressão "vinda da Rainha de Portugal", que se refere á vinda da Família Real para o Brasil. Antonio G. TEIXEIRA E SOUSA, op.cit., Tomo I, 1847.

${ }^{137}$ Idem, op.cit., Tomo II, 1855.

${ }^{138}$ Ibidem, 1855.

${ }^{139} \mathrm{O}$ poeta esclarece que transcreveu a declaração no poema pois no livro História do Brasil, o general Abreu e Lima apontou que não a encontrou para incluir na obra. Trata-se da obra: José Ignácio ABREU E LIMA, Compêndio da História do Brasil, Tomo I e II. Rio de Janeiro: Casa dos Editores Eduardo e Henrique Laemmert, 1843.

140 Esse aspecto será tratado adiante.
} 
uma interpretação de Independência pacífica ou acordada. Também fica evidente que não ocorre a relevância ou preponderância da história ou memória de uma região do Brasil sobre outra.

Na epopeia Paraguassú (1835- 1837), como o foco são as lutas da Independência entre os exércitos baiano/brasileiro e luso, pouco pôde se inferir sobre a Independência entendida como um processo. Extrapolando as lutas ocorridas na Bahia, que são centrais no poema, há manifestações de intenções danosas ao Brasil por parte das Cortes Portuguesas, ponto que será tratado de forma detida adiante, quando analisamos o conceito de despotismo conectado com uma ideia de suposta intenção de "recolonização" do Brasil por parte de Portugal. Ademais, no trecho : "O valor experimentado,/ E a Proteção de PEDRO heroico e Grande;/ PEDRO o paládio da União Brasilia..." ${ }^{141}$, entende-se que a união das províncias ocorreu devido à atuação central de D. Pedro, este considerado o protetor do Brasil.

Assim, embora o poema Paraguassú trabalhe a ideia dos muitos heróis, iniciando pelo Visconde de Pirajá, a quem é dedicado o épico, e todos que lutaram pela Independência do Brasil e da Bahia, fica manifesta uma concepção de atuação do regente D. Pedro como aglutinador da unidade territorial no Brasil e defesa da Independência. Essa mesma concepção foi levada adiante por Varnhagen na historiografia e que se tornou tradicional, como já tratado anteriormente. ${ }^{142}$

Avançando cronologicamente, outro poema que trata da Independência com uma abordagem cronológica ampla é o Cordel da história da Independência (2008), que começa com a invasão de Napoleão Bonaparte a Portugal, logo após a desobediência ao embargo econômico imposto pela França aos países continentais, a transferência ("fuga" de acordo com o Cordel) da Família Real para o Brasil; a abertura da economia e elevação do Brasil a Reino Unido. Tiradentes e a Inconfidência Mineira também são citados: "Sentiu D. João os anseios/ Quando no Brasil chegou,/ Os cantos da liberdade/ Pelo sangue que jorrou,/ Pedaços de Tiradentes/ Do corpo que esquartejou"143.

A Inconfidência Mineira é referida a partir de Tiradentes, a quem se atribui, em versos, “que sonhou um Brasil livre,/ Por seu povo independente."144. É possível

\footnotetext{
${ }^{141}$ Ladislau dos Santos TITARA, op.cit., p.535. Foi preservado o uso das letras maiúsculas conforme o poema.

${ }^{142}$ Francisco Adolfo de VARNHAGEN, História Geral do Brasil. Tomo I. Rio de Janeiro: Laemmert, 1854; Francisco Adolfo de VARNHAGEN, História da Independência do Brasil. Rio de Janeiro : Instituto Histórico e Geográfico Brasileiro, 1916.

${ }^{143}$ Luzimar Medeiros BRAGA, op.cit., p.11.

144 Ibidem, p. 11
} 
compreender que neste cordel a Inconfidência é entendida como um projeto de emancipação para o Brasil e não para a província de Minas Gerais.

A construção narrativa é feita em versos rimados, e apresentando aqui um mapeamento da poesia são citadas: a fundação da Academia Militar e Naval; a Casa da Moeda; o Banco do Brasil; a Biblioteca Real ${ }^{145}$; o Jardim Botânico, a criação da Imprensa Régia, o Teatro São João, a vinda da Missão Francesa; e a fundação de Escolas de Medicina na Bahia e Rio de Janeiro. ${ }^{146}$ Também é apontada a elevação do Brasil a Reino Unido de Portugal e Algarves, o retorno de D. João a Portugal, o "Fico", e a declaração da Independência do Brasil às margens do riacho do Ipiranga. O governo de D. Pedro é apontado como "truculento" pelo fechamento da Assembleia Constituinte, pela criação do poder "Moderador" e pela outorga da Constituição ${ }^{147}$. Há ainda menção à indenização que o Brasil pagou a Portugal para reconhecimento da Independência, e a dependência econômica do Brasil com a Grã-Bretanha ${ }^{148}$.

Neste Cordel, a Independência é apontada como "combinada", feita como um acordo pelos detentores do poder, sem a participação do povo: "Não escuto o som do grito/ Pela "Independência ou Morte",/ Tudo foi arrumação/ Tendo o poder por suporte, Foi tudo um jogo de cartas/ Já marcadas pela sorte"149. Essa ideia de Independência negociada/arranjada, também ganhou eco na historiografia, e não surpreende que encontremos essa interpretação em uma obra literária publicada em 2008, uma vez que, como já apontado, a cultura de história é muito difusa, portanto essas ideias podem já estar inseridas em imaginários populares.

As lutas da independência na Bahia são lembradas no Cordel: "As lutas de "independência"/ Ocorreram na Bahia,/ O português inocente,/ De amor à pátria reagia,/ Desconhecendo o acordo/ Secreto que então havia." ${ }^{150}$ A interpretação da independência acordada é reafirmada, inclusive pelo uso de aspas na palavra independência. Em seguida é introduzida a disputa pela memória das comemorações em torno da Independência na Bahia:

\footnotetext{
145 Ibidem, p.08.

${ }^{146}$ Ibidem, p.09. No verso consta "Missões de artes francesas".

${ }^{147}$ Ibidem, p.16-17.

${ }^{148}$ No verso foi empregado "Inglaterra" e não "Grã-Bretanha".

${ }^{149}$ Luzimar Medeiros BRAGA, op.cit., p.19

${ }^{150}$ Ibidem, p. 15.
} 
Só no "Dois de Julho"/ Foi que a luta terminou,/ Portugueses depuseram/ As armas ao vencedor/ E D. Pedro era aclamado/ Como sendo imperador.

E a data dois de julho/É o dia por excelência/ Que então se comemora/ $\mathrm{Na}$ Bahia a independência/ Onde todo o povo exalta,/ Pela arte a experiência. ${ }^{151}$

O caso da Bahia em torno das comemorações da independência é um dos mais emblemáticos acerca da construção da memória e disputas em torno da história da Independência, por conta da luta final que ocorreu no dia 02 de julho de 1823 . A data demarca a expulsão das tropas portuguesas de Salvador, sendo por esse motivo considerada a data de comemoração da Independência na Bahia, e faz parte do calendário oficial estadual de comemoração cívica, embora a data oficial nacional de comemoração da Independência seja o Sete de Setembro. ${ }^{152}$

Além de incluir no cordel as lutas de independência na Bahia comemoradas pelo povo, o autor segue reiterando a ideia de Independência negociada e a expandindo, ressaltando a participação popular numa verdadeira luta, a partir dos ideias da conjuração mineira. Assim, os "idealistas que a inconfidência [mineira] gerou" 153 , eram os que verdadeiramente combatiam através de suas ações pela Independência, "construindo a revolução com luta" 154 . O autor critica a Independência que se comemora nas "paradas cívicas, no discurso emocionado" 155 , pois não teve a participação do povo. Outro ponto que chama atenção nessa obra, é que dentre as produzidas no século XXI, das aqui analisadas, esta foi a única que abordou de forma alargada o processo de Independência, incluindo as lutas na Bahia e os ideais da Inconfidência Mineira.

No final do cordel foram colocados em itens os temas abordados. Quando o autor aponta a Independência, descreve da seguinte maneira: "A Independência - Uma Farsa?"156. Reafirmando mais uma vez, a ideia de uma "não-independência", ou de um

\footnotetext{
151 Ibidem, p.15-16.

152 Gerson Ledezma trata das disputas comemorativas no centenário da Independência na Bahia. Embora tenham sido promovidos eventos comemorativos na data nacional oficial, ou seja, o sete de setembro em 1922, no ano seguinte foram feitos festejos com ampla adesão popular na comemoração do dois de julho em 1923. Gerson Galo LEDEZMA. "Religiosidade cívica na Bahia: Comemorando o primeiro centenário da Independência a 2 de julho de 1923. Entre a memória nacional e a memória regional." In: Revista Esboços, volume 16, n 21, UFSC, p.69-87.

${ }^{153}$ Luzimar Medeiros BRAGA, op.cit., p.19.

154 Ibidem, p.19.

155 Ibidem, p. 19

${ }^{156}$ Ibidem, p. 21.
} 
acordo entre D. João e D. Pedro, sem participação popular.

Esta é uma das poucas obras publicadas no século XXI, que aborda a Independência entendida como um processo e inclui também as lutas ocorridas na Bahia. Este pode ser um indício de uma ênfase geral, de destaque da história da Independência nos eventos do Rio de Janeiro e São Paulo (em especial, o grito às margens do riacho do Ipiranga), em detrimento da história das lutas no processo de Independência que ocorreram em outras regiões do país. Esse foco centralizado na versão do Sudeste indicaria uma quebra do entendimento da Independência enquanto um processo amplo e complexo que se dispersou em lutas variadas no território brasileiro em momentos diversos? A publicação de dois romances recentes sobre a revolução de Pernambuco de 1817, ambos com forte marca didática, poderia indicar que sim. Esse parece ser um indício de um ofuscamento das lutas ocorridas em outras regiões do Brasil, e também de um entendimento fragmentado da Independência, evidenciando alguns eventos e regiões, em geral do Sudeste. ${ }^{157}$.

Temos em Memórias Póstumas de Brás Cubas, um recorte cronológico que vai de 1805 a 1869, e vamos focar aqui no período entre a chegada da Corte e abdicação de D. Pedro, em 1831. Brás Cubas nasceu em 20 de outubro de 1805 e quando o Brasil se tornou independente, em 1822, o protagonista completou 17 anos.

John Gledson aponta que a construção do romance faz referências históricas, com destaque a alguns episódios políticos como a Independência, a abdicação de D. Pedro I, a Maioridade, a Lei do Ventre Livre, a Abolição da escravatura e a República ${ }^{158}$. Roberto Schwarz pondera sobre as propostas do crítico da obra de Machado de Assis, John Gledson: “ de passagem, Gledson, levanta uma boa pergunta: e se Brás fosse o Brasil, de que seu nome é a primeira sílaba?"159. A partir desse questionamento, Schwarz propõe também algumas aproximações entre a vida de Brás Cubas e momentos históricos do Brasil. Dentre eles, as celebrações da Independência,em 1822, momento em que o

\footnotetext{
157 Talvez um levantamento cruzado,que incluísse os livros didáticos e obras literárias que tivessem foco na história de lutas regionais, não apenas do Nordeste mas também do Norte, Sul e Centro-Oeste do Brasil, pudessem indicar de forma assertiva se este é um dado confirmado e não apenas indicativo. Thamara Rodrigues apresenta um balanço historiográfico sobre o movimento pernambucano de 1817 e aponta uma "marginalização" ou "esquecimento" deste se comparado com a Inconfidência Mineira: Thamara de Oliveira RODRIGUES, "A Revolução pernambucana e as disputas historiográficas: Abreu e Lima e Francisco Adolfo de Varnhagen”. In: História e Cultura. Franca, v. 6, n.1, p.289-308, mar.2017.

${ }^{158}$ Apontamentos sobre o estudo de John Gledson feita por Roberto SCHWARZ, Um mestre na periferia do capitalismo: Machado de Assis. São Paulo: Duas Cidades: Editora 34, 2000, p.74. O autor recomenda especialmente a "Introdução" e os capítulos sobre Casa Velha e Bons Dias!. Em: John GLEDSON, Machado de Assis: ficção e história. Sônia COUTINHO (tradução). Rio de Janeiro: Paz e Terra, 1986.

${ }^{159}$ Roberto SCHWARZ, op.cit., p.74.
} 
narrador vê pela primeira vez Marcela, sua primeira paixão ou "cativeiro", como Brás Cubas descreve. "Paradoxo que não é fortuito" como aponta Schwarz. ${ }^{160}$ Brás Cubas se refere da seguinte forma aos dois acontecimentos:

"Vi-a pela primeira vez, no Rossio Grande, na noite das luminárias, logo que constou a declaração da independência, uma festa de primavera, um amanhecer da alma pública. Éramos dous rapazes, o povo e eu; vínhamos da infância, com todos os arrebatamentos da juventude". ${ }^{161}$

A independência representa a maioridade do Brasil, celebrada, mas chegando com os "arrebatamentos da juventude". Metáfora ambígua, pois arrebatamento pode significar êxtase ou inconsideração, ímpeto ou força ${ }^{162}$. Tipo de linguagem própria do narrador, que deixa a interpretação em aberto. A independência representada como a "maioridade" do Brasil reflete uma concepção de emancipação vigente já desde a própria Independência, tomada esta como um caminho inevitável, esperado. Um acontecimento natural na história das colônias, que indicaria sua "maturidade", tendo como exemplos as independências das Treze colônias inglesas da América do Norte, de Saint-Domingue, e das colônias da América espanhola ${ }^{163}$

Schwarz, ainda baseado nos estudos de Gledson, segue com a correspondência entre a ficção e a história e destaca: tendo o romance entre Marcela e Brás Cubas interrompido, o narrador é enviado para estudar em Coimbra. Quando obtém o bacharelado o narrador avalia: "era um acadêmico estroina, superficial, tumultuário e petulante, fazendo romantismo prático e liberalismo teórico, vivendo na pura fé dos olhos pretos e das constituições escritas." 164 Schwarz considera uma "alusão ao Primeiro Reinado, ao Imperador e à maneira pela qual o Brasil, recém-saído do confinamento colonial, abraçava as ideias modernas."165 Por fim, Brás Cubas retorna da Europa, pois

\footnotetext{
160 Ibidem, p.75.

${ }^{161}$ Machado de ASSIS, op.cit, p.76.

${ }^{162}$ No Diccionário da Língua Brasileira de Luiz Maria da Silva PINTO, publicado em 1832, o significado de arrebatamento aparece como: s.m. Ação de levar por força. Inconsideração. No Diccionário da Língua Portugueza de Antonio de Moraes SILVA (p.238), publicado em 1890, arrebatamento: s.m ação ou feito de arrebatar - se. Extasis, enlevação. V. Rebatamento. Movimento mui rápido; ímpeto, força, veemência com que impele alguma coisa. [sic]. Transporte de paixão, bom ou mau, de que procedem coisas extraordinárias.

${ }^{163}$ João Paulo Garrido PIMENTA. "De Raynal a De Pradt: apontamentos para um estudo da idéia de emancipação da América e sua leitura no Brasil”. Almanack Braziliense, [S.1.], n. 11, p. 88-99, may 2010. ${ }^{164}$ Machado de ASSIS, op.cit., p.95.

165 Roberto SCHWARZ, op.cit., p.76.
} 
sua mãe estava doente e "havia oito ou nove anos que não se viam." ${ }^{\text {"166 }}$ Roberto Schwarz, continua a correspondência com a história e esclarece: trata-se de 1832. Pouco tempo depois o pai do narrador também falece, e "Brás fica órfão, como se dizia que ficara o Brasil com a abdicação de D. Pedro I em 1831."167

É o próprio Schwarz que destaca que as correspondências entre a história e a ficção, a partir da vida e eventos que ocorrem com Brás Cubas, este que representaria o Brasil, seriam percebidas pelo o que chama de "leitores iniciados". Com isso, destacamos a importância do repertório dos leitores para interpretação das obras literárias. No caso do livro de Machado de Assis, como a correspondência com a história do Brasil foi elaborada pelo escritor de maneira indireta e sutil através da ficção, o repertório do leitor torna-se ainda mais necessário para que seja possível perceber a alusão à história.

Seguindo com o conjunto de poemas da obra História do Brasil (1932) de Murilo Mendes, os episódios que se referem à Independência são: a transferência da Corte para o Brasil ("Embarque do papagaio Real”); dois poemas sobre personagens da Revolução Pernambucana ("A mão de Domingos José Martins" e "Relíquias de Frei Caneca”); a decisão de D. Pedro de permanecer no Brasil, rejeitando a convocação de retorno feita por Portugal ("Fico"); os eventos que antecedem a declaração da Independência ("Preparativos da Pescaria", o uso de preparativos no título passa uma ideia de Independência como premeditada); as relações amorosas de D. Pedro expressas em "Serenata da Dependência". Neste poema, embora a organizadora da edição utilizada nesta pesquisa, Luciana Picchio, aponte que se trata das relações amorosas de D. Pedro ${ }^{168}$, interpretamos de outra forma, pois no poema é apontada a insatisfação de Portugal pelo atraso em receber quantias em dinheiro do príncipe. A frase "Escreverei para a Inglaterra"169, indica que se trata da dependência econômica do Reino português para com a Inglaterra. O último poema, “A pescaria” refere-se ao episódio às margens do Ipiranga e ao grito da Independência. Portanto, acompanhamos em tom satírico episódios do processo de Independência brasileiro.

O poeta destacou eventos marcantes da história da Independência, construindo poemas individuais sobre cada data ou tema. A construção poética característica do

\footnotetext{
166 Machado de ASSIS, op.cit., p.103.

${ }^{167}$ Roberto SCHWARZ, op.cit., p.77.

${ }^{168}$ José Alberto P.NEVES também aponta que o poema trata de uma conversa de D. Pedro com uma amante. Em: José Alberto Pinho NEVES, História do Brasil de Murilo Mendes: travessia para o conhecimento. Tese de Doutorado. Programa de Pós-Graduação em Educação da Universidade Federal de Juiz de Fora. 2016

${ }^{169}$ Murilo MENDES, “Serenata da Dependência”, op.cit., p.44.
} 
Modernismo faz chiste com a história do Brasil, os personagens da Família Real são rebaixados, ridicularizados, assim como o episódio do grito da Independência ${ }^{170}$. Temos, portanto, a partir de uma “memória oficial”, um rebaixamento da história através da sátira.

Em Viva o Povo Brasileiro (1984), quando se trata da independência (pois o livro aborda muitos momentos da história do Brasil), o foco são as lutas de independência na Bahia contra as tropas lusas, mas encontramos passagens sobre D. Pedro e D. João. Por exemplo, na voz da personagem Dadinha ${ }^{171}$ é apenas citado o retorno do último à Portugal. As lutas na Bahia são tematizadas através de personagens fictícios que participaram dos eventos, e são feitas citações breves sobre personagens históricos como Maria Felipa, Sóror Joana Angélica ${ }^{172}$, e Lorde Cochrane ${ }^{173}$. Da mesma forma, em citações pontuais são feitas referências à revolução de Pernambuco, em geral nomeando

\footnotetext{
${ }^{170} \mathrm{O}$ poema é analisado no capítulo 2.

${ }^{171}$ O episódio ocorre em Porto Santo da Ilha em 10 de junho de 1821, quando Dadinha, personagem muito respeitada entre os cativos,que "recebia entidades" em rituais da religião de matriz africana, quase centenária, relata que vai morrer e numa dessas cerimônias conta toda a história (a mesma do livro), sobre os personagens que reencarnam na narrativa, e também a história do Brasil, momento em que cita o retorno de D. João a Portugal. In: João Ubaldo RIBEIRO, op.cit, P.83-94.

${ }^{172}$ Maria Quitéria e a Sóror Joana Angélica, foram elevadas ao estatuto de heroínas da Independência, sendo muito celebradas sobretudo na Bahia. Maria Quitéria fingiu ser um homem para conseguir se alistar nas tropas baianas, e dessa forma lutou pela Independência juntando-se às tropas baianas. Foi condecorada por D. Pedro I com a insígnia da "Imperial Ordem do Cruzeiro". Joana Angélica, foi assassinada por soldados lusos sob comando do general Madeira, quando invadiram o Convento da Lapa. Ver: Gerson Galo LEDEZMA. "Religiosidade cívica na Bahia: Comemorando o primeiro centenário da Independência a 2 de julho de 1923. Entre a memória nacional e a memória regional." In: Revista Esboços, volume 16, no 21, UFSC, p.69-87; Bernardino José de SOUZA, Heroínas Bahianas: Joanna Angélica, Maria Quitéria, Anna Nery. Rio de Janeiro: Paralelo; Brasília: Instituto Nacional do Livro, 1972. E: Gabriella Assumpção da Silva Santos LOPES; Marcela de Oliveira Santos SILVA, “"Heroínas Bahianas": Personagens femininas nas comemorações do centenário da Independência da Bahia”. In: XII Encontro da Associação Nacional de História: Democracias e Ditaduras no Mundo Contemporâneo. Seção Mato Grosso do Sul. 13 a 16 de outubro de 2014. UFMS/CPAQ, Aquidauana-MS, p. 1-10.

${ }^{173}$ Lord Cochrane, cujo nome era Thomas Alexander Cochrane, nasceu na escócia, possui os títulos de $10^{\circ}$ Conde de Dundonald; Marquês do Maranhão, título concedido por D. Pedro I em 1823, se destacou nas batalhas navais contra Napoleão Bonaparte e suas tropas. Entre 1823 e 1825 prestou serviços para o Império Brasileiro, por solicitação de D. Pedro I; e foi o I Almirante Brasileiro. Aldo M. AZEVEDO, "Lord Cochrane. O Primeiro Almirante Brasileiro". Revista de História, v.9, n.19, 1954, p.101-130; Vasco MORIZ, "Lorde Cochrane, o turbulento Marquês do Maranhão". Revista Navigator, v.8, n.16, 2012, p.1120.
} 
personagens como Frei Caneca ${ }^{174}$ e o Padre Roma ${ }^{175}$ : "Não foi esse o padre Roma, que com seus filhos mataram, padre Roma esse sendo muito dispois na história, foi por fazer sedição que lhe deram cadafarso [sic]." ${ }^{\text {176 }}$

A Independência, nessa obra, é muito politizada, tematizando sobretudo as lutas em torno do projeto de Brasil que se discutia na visão de uma classe dominante e de uma classe subalterna (cativos, libertos e pobres). Como exemplo, cito a passagem sobre o grupo que formou a "Sociedade dos Filhos da Independência Sete de Janeiro" criada para "fins literorrecreativos, colimando ainda o fomento dos ideais do amor à Pátria, do espírito público e dos valores mais acentuados da Nacionalidade." ${ }^{177}$ Em discussão sobre a disputa de chapas para o biênio 1869-1870, o personagem João Popó, da chapa "Autoridade", opositora da chapa "Liberdade"178 que foi a vencedora, diz que não consentiriam (jamais) que uma agremiação que leva Independência no nome fosse "regida por escravos e filhos de escravos." 179 A passagem ocorre no enredo em 1870, mas a Independência ainda é tematizada na voz de um personagem que vocalizava os valores de uma classe dominante destacando uma divisão social, conectando-a com a Independência, esta tida como símbolo da liberdade. Dessa maneira, escravidão e liberdade são evocados através da referência à Independência.

A obra Galantes Memórias e Admiráveis Aventuras do Virtuoso Conselheiro Gomes, o Chalaça (1994), aborda alguns eventos do processo de Independência. Como o

\footnotetext{
${ }^{174}$ Frei Joaquim do Amor Divino Rabelo Caneca, da Ordem dos Carmelitas, foi um dos padres ilustrados que participou da Revolução de Pernambuco de 1817- popularmente conhecida como Revolução dos Padres -, junto aos líderes. Foi preso pelo envolvimento na revolução, em 1821 foi libertado. Em 1824 foi um dos líderes da Confederação do Equador, sendo preso e executado em ritual público em 1825. Sobre o personagem consultar: Marco MOREL, Frei Caneca: entre Marília e a Pátria. Rio de Janeiro: FGV, 2000; Mariana dos Santos RIBEIRO, "Frei Caneca e a Confederação do Equador". In: Revista Intelléctus/ Ano 05, vol II, 2006; João Alfredo de Sousa MONTENEGRO, O liberalismo radical de Frei Caneca. Rio de Janeiro: Tempo Brasileiro, 1978. E indicamos também o poema de Evaldo Cabral de MELLO, Auto do frade: poema para vozes. Rio de Janeiro: Nova Fronteira,1984. Do mesmo autor há ainda uma publicação com um conjunto de textos de Frei Caneca: Evaldo Cabral de MELLO (org. e intro.), Frei Joaquim do Amor Divino Caneca. São Paulo: Editora 34, 2001.

${ }^{175}$ O Padre Roma, como era conhecido, se chamava José Inácio Ribeiro de Abreu e Lima, foi um dos líderes da Revolução de Pernambuco de 1817, sendo executado por isso. Seu filho José Ignácio de Abreu e Lima é autor de: José Ignacio ABREU E LIMA, Compêndio da História do Brasil, Tomo I e II. Rio de Janeiro: Casa dos Editores Eduardo e Henrique Laemmert, 1843.

176 João Ubaldo RIBEIRO, op.cit., p.88-89.

${ }^{177}$ Ibidem, p.470. Essa era uma instituição, na narrativa, reconhecida pelo Município e pela província Itaparica- como de utilidade pública.

${ }^{178}$ A chapa de João Popó, "Autoridade", era conservadora e "contra a dissolução dos bons costumes, o livre pensamento, as ideias republicanas e abolicionistas, a liberdade de religião, e tudo mais quanto representasse o solapamento dos alicerces sobre os quais deve assentar-se uma verdadeira civilização." In: João Ubaldo RIBEIRO, op.cit., p.471. Dessa maneira, João Popó e sua chapa, representam os pensamentos para manutenção de projetos e valores da classe dominante da região do Recôncavo Baiano.

${ }^{179}$ Ibidem, p.471.
} 
romance segue a vida de Chalaça, a narrativa que lembra do período em que viveu no Brasil $^{180}$ (que configura seu diário) começa no dia do embarque da Corte para o Brasil, em Lisboa. Há um salto temporal, e é descrita a viagem de D. Pedro à São Paulo e Santos e os episódios às margens do riacho do Ipiranga, momento em que descreve o grito de Independência; a Assembléia Constituinte de 1823 e sua dissolução; a elaboração da Constituição e sua outorga em 1824; a derrota na Cisplatina ${ }^{181} \mathrm{em} 1828$, e a abdicação de D. Pedro ao trono, em 1831. Exceto os episódios da viagem de D.Pedro e do grito do Ipiranga, os outros são narrados sem entrar em maiores detalhes, adentrando na narrativa outros aspectos ficcionais que ganham maior destaque. Em geral, os eventos são narrados de forma cômica, episódica, sem aprofundar questões políticas. O foco maior do livro recai na descrição dos personagens.

Em Era no tempo do rei (2007), embora o foco da história sejam as travessuras do infante Pedro e do personagem Leonardo, alguns episódios do período são abordados ainda que não sigam uma ordem cronológica: invasões de Napoleão à Península Ibérica e ultimato a Portugal quanto ao embargo comercial da Grã-Bretanha; transferência ("fuga""182) da Corte com escolta britânica; a Revolução Francesa; o contexto sobre a questão da sucessão do trono espanhol, com José Bonaparte tomando o poder; as independências das colônias da América Espanhola; a modernização do Brasil com a vinda da família real; o fim das guerras napoleônicas e o contexto econômico com o centro do poder português na colônia.

No romance, é possível perceber uma visão que insere o Brasil num contexto revolucionário do século XIX e das revoluções de Independência na América, através da figura de Carlota Joaquina e seu interesse no trono espanhol, e também com as invasões napoleônicas em Portugal e na Espanha. Dessa forma, o Brasil é incluído nesse processo de profundas mudanças que estavam ocorrendo no século XIX na Europa e América.

As obras que tratam da Revolução de Pernambuco centralizam a narrativa em torno dos líderes revolucionários, e o projeto republicano alternativo para Pernambuco. Entretanto, é possível identificar considerações sobre a Independência. Em Olhos Negros (2009), são apontadas duas independências, como discorre a narradora, Maricotinha. No

\footnotetext{
${ }^{180}$ Lembro aqui que o livro é dividido em dois blocos, os escritos do "suposto diário" do Chalaça, que narra o período em que viveu no Brasil antes de ser expulso; e as descrições da luta entre D.Pedro e D. Miguel na disputa do trono português, momento em que já vivia na Europa. As duas narrativas são intercaladas no livro.

${ }^{181}$ O narrador, aponta a "derrota" quando trata da luta pela Província Cisplatina, em 1828.

${ }^{182}$ Ruy CASTRO, op.cit.,p.23.
} 
contexto, a narradora explica o movimento levantado por Mena Calado em 1821 a favor do regime constitucionalista que se disseminou pela província de Pernambuco com adesão de Goiana, Nazaré, Limoeiro e Tracunhaém ${ }^{183}$. O movimento ganhou força até a queda de Luís do Rego, quando Gervásio Pires assumiu a presidência da província: “Tornamo-nos território independente muito antes do mês de setembro de 1822. Entre uma independência e outra, a agitação nas ruas era coisa comum..." ${ }^{184}$ Aqui fica expressa a ideia da independência de Pernambuco, porém não através do projeto alternativo de 1817, mas do movimento constitucional em $1821^{185}$, concorrendo com a independência nacional. Quando a narradora comenta sobre o fato de Muniz Tavares ter assinado a Constituição das Cortes portuguesas, é novamente abordada a Independência do Brasil:

Um pouco de clarividência logo lhe mostraria que ela [a Constituição] seria atropelada pela declaração da independência do Brasil. Pensávamos que sua argúcia não antevira este fato tão esperado e anunciado... [Muniz Tavares] Deixou que a própria história nos ensinasse que a independência e a constituição prometidas por Pedro I não mereciam qualquer confiança... ${ }^{186}$

É possível entender que a crítica e a desconfiança com o monarca se referem ao fato da Constituinte ter sido dissolvida e a constituição outorgada por D. Pedro I. Fica subentendida ou sugerida uma ideia de Independência como uma farsa, entendida não como um acordo, mas devido a atitude de D. Pedro, com a dissolução da Constituinte. Quando Maricotinha ( a narradora) discorre sobre Carlota Joaquina, se refere a ela como "mulher desagradável e absolutista, e Leopoldina, a filha obediente do imperador da Áustria, Leopoldo de Habsburgo"187. E conclui o pensamento: "Nosso "novo império" cheirava mal. Cheirava à Santa Aliança [...] O nosso império era visto com suspeitas." 188

\footnotetext{
183 Trata-se do movimento de Juntas de governo provisório na província de Pernambuco. Filipe Mena Calado da Fonseca foi secretário da junta de Goiana.

${ }^{184}$ Maria Cristina C. de ALBUQUERQUE, op.cit., p.118.

185 João Paulo Pimenta aponta que o "embora norteado por um projeto politicamente vago e pouco articulado, seu caráter de frontal contestação ao governo monárquico é dado pela recorrência a uma ideia (igualmente vaga) de "república", a qual se pretendia erguer na condição de um modelo político alternativo ao vigente.” Em: João Paulo PIMENTA, “A política Hispano-americana e o Império Português”. In: István JANCSÓ (org.), Brasil: Formação do Estado e da Nação. São Paulo- Ijuí: Hucitec: Ed.Unijuí: Fapesp,2003, p.133. Embora fosse um projeto vago, nas obras literárias que tratam da revolução Pernambucana foi adotada a designação de um projeto republicano por parte dos revolucionários.

${ }^{186}$ Maria Cristina C. de ALBUQUERQUE, op.cit., p.47- 48.

${ }^{187}$ Ibidem, p.329

${ }^{188}$ Ibidem, p.329-330.
} 
Em A Noiva da Revolução (2006) de Paulo Santos de Oliveira, o relato termina em 1818, e há um breve apêndice que esclarece o destino de alguns participantes do movimento, mas o foco do romance é a Revolução Pernambucana narrada dia a dia, como num diário. Já o romance de Manuel Antonio de Almeida, Memórias de um sargento de Milícias (1852 - 1853), apresenta costumes e ritos do Rio de Janeiro do período Joanino, sem inferir sobre a política, ou o processo de Independência; mas em outros temas abordados na pesquisa, sobretudo no capítulo 3, a obra é importante.

Dessa maneira, foi possível mapear como cada objeto analisado aborda a Independência e dispensa tratamentos distintos em termos de recorte cronológico.O Épico Independência do Brasil (1847 e 1855), e Primícias (1900), o Cordel da história da Independência (2008), Chalaça (1994) e o romance Era no tempo do rei (2007), embora o último não siga uma ordem cronológica linear, apresentam o processo de Independência. Outras obras literárias destacam eventos e personagens, apontando ênfases diversas, como os romances que têm por tema a revolução de Pernambuco de 1817, ou o épico Paraguassú e o romance Viva o Povo Brasileiro (1984), com foco nas lutas que ocorreram na Bahia. Memórias Póstumas de Brás Cubas (1880) e Memórias de um sargento de milícias (1852-1853) centralizam a narrativa no meio urbano do Rio de Janeiro. No caso de Brás Cubas, o vida do narrador funciona como uma alusão à história do Brasil, com eventos marcantes coincidindo com datas importantes do processo de Independência. O conjunto de poemas de Murilo Mendes, inseridos no livro História do Brasil (1932), aborda eventos e personagens da Independência. O objetivo maior dos poemas de Murilo Mendes é satirizar a história do Brasil, também como uma forma de crítica, inserida nos preceitos do Modernismo.

Foi possível verificar que certos conceitos caros a parte da historiografia e estudos sobre a Independência são repetidos nas obras literárias, o que indica a importância deles para a caracterização e entendimento do período e do processo de Independência. Porém, os conceitos foram utilizados com sentidos variados. Assim sendo, apresentarei a seguir, a análise de cada um destes conceitos e como os sentidos sofreram mudanças em cada uma das obras literárias e conforme cada período de publicação. Por fim, será possível perceber como o uso dos conceitos indicam aproximações com debates e interpretações historiográficas. Dessa maneira, será possível compreender melhor alguns temas e representações da Independência que foram apontados anteriormente. 


\subsection{Conceitos}

Ao longo da análise dos objetos aqui tratados foi possível perceber o uso de certas palavras e conceitos de formas variadas. Aqui apresentarei uma análise sobre como cada um desses termos foi empregado, apresentando diferentes ideias e abrindo campo para interpretações diversas. Não se pretende, dessa maneira, elaborar uma definição dos conceitos, mas elaborar uma leitura e análise historicizante de cada um deles.

Nas obras literárias, o termo despotismo foi utilizado em alguns momentos. Inicialmente atribuído a Portugal nas discussões das Cortes de Lisboa em relação ao Brasil, posteriormente também é encontrado também se referindo à D. Pedro I quando este dissolveu a Constituinte em 1823, e ainda, próximo ao período de sua abdicação. Normalmente ligada à ideia de despotismo aparece o emprego de expressões que remetem a uma interpretação de recolonização do Brasil por parte de Portugal, termo que ganhou força nas discussões das Cortes Portuguesas.

Uma das obras que mais trabalha com as ideias de ligação entre despotismo e recolonização é o poema épico de Teixeira e Sousa. O despotismo por parte de Portugal e manifesto sobretudo nas Cortes de Lisboa, faz-se presente no poema desde o primeiro canto. Este despotismo se vincula à ideia de uma tentativa recolonizadora por parte de Portugal.

\footnotetext{
Em seus atros furores encendido/ Seguindo o plano túmido, interesseiro/ De Lisboa o Congresso enfurecido/ Aniquilava o reino Brasileiro!/ Era então seu propósito querido/ O reduzí-lo a extremo cativeiro!/ E, tendo-o conquistado o Servilismo,/ Nele dar leis o negro Despotismo! ${ }^{189}$ (grifos meus)
}

Na epopeia , foi elaborada uma construção em que surgem do abismo a Discórdia, o Ódio, o Despotismo, a Vingança, a Anarquia, a Guerra, a Ira, a Intriga, a Falsidade, o Servilismo, a Hipocrisia, a Ingratidão e Mentira, escritos como nomes próprios, pois aparecem como entidades a influenciar pessoas, ânimos e eventos. Contudo, dentre todos, “aquele, que é chamado Despotismo/ É o monstro mais ímpio, e mais sangrento..."190

\footnotetext{
${ }^{189}$ Ibidem, op.cit., p.17.

${ }^{190}$ Antonio Gonsalves TEIXEIRA E SOUSA, op.cit, Tomo I, p.222.
} 
É interessante que o poeta narra uma reunião no Inferno das entidades descritas acima. De lá o Despotismo voa para Lisboa, a Anarquia voa para o norte do Brasil, e a Discórdia paira sobre o resto ${ }^{191}$. Dessa forma, o autor constrói uma analogia à reunião das Cortes em Lisboa, de onde o despotismo surge contra o Brasil. Com ele a agitação política que se espalha no norte do país, devido à adesão ou não à constituição elaborada em Portugal. A ideia de recolonização se faz presente em expressões como a descrita no excerto acima, "reduzí-lo ao extremo cativeiro", mas também de forma mais expressa em outro verso: "Porque o Brasil à Portugal ligado/ Desfaz o laço, que apertara há um ano!/ Eis: saiu do caminho começado/ O Congresso, e de cego, audaz, insano,/ Quis o Brasil de novo avassalado/ Ao vil, colonial, jugo tirano! (grifos meus)"192. Nesse verso quem fala é o "Anjo dos Destinos" a D. Pedro. Encontramos a mesma noção de recolonização em outra expressão como: “[Pátria querida] ...Descansa, que teus filhos sempre bravos/ Nunca mais tornarão a ser escravos. (grifos meus)"193 Assim como, em: "Era da trama o almejado efeito/ $O$ ver aos ferros o Brasil tornado!." ${ }^{194}$ Em suma, a interpretação de que Portugal tinha intenção de recolonizar o Brasil nas Cortes está presente em todo o poema de Teixeira e Sousa.

Entretanto, como destacado no verso a seguir:

Não nos-causa pavor quem nesta idade/ As unhas contra nós raivando eriça :/ Gozar de nossa doce liberdade/ Nosso querer foi só, nossa cobiça :/ Com a vossa juntar nossa igualdade/ Era dever em vós, em nós justiça;/ Mas a vossa ambição, vossa imprudência/ Dar-nos-hão o sinal da independência! ${ }^{195}$

É possível depreender que na obra (em outros versos essa mesma ideia aparece) a condição do despotismo era percebida na medida em que o Brasil, como parte do Reino Unido, elevado a um estatuto de igualdade a Portugal em 1815, estava sendo subjugado nas Cortes. Se não fosse por esse motivo, então não existiriam motivos para a Independência, embora o "amor à Liberdade" do Brasil e dos brasileiros seja destacado em muitos versos, inclusive referindo-se à revolução de Pernambuco de 1817. Quando

\footnotetext{
191 "Ergue-se ardente em fervida ousadia/ Para amparo lhe-dar o infausto Abysmo!/ Não temem a Discórdia, a Anarchia/ Nem de ti, nem dos teus todo heroismo,/ Voaram dos Infernos a porfia;/ Dirigiu-se a Lisboa o Despotismo;/ Voa a Anarchia do Brasil ao norte/ E no resto a Discórdia adeja forte." Antonio Gonsalves TEIXEIRA E SOUSA, op.cit., Tomo I, p.284.

${ }^{192}$ Antonio Gonsalves TEIXEIRA E SOUSA, op.cit., Tomo II, p.293.

${ }^{193}$ Ibidem, p.319.

194 Ibidem, p. 154.

195 Ibidem, p. 180.
} 
descreve que a "aurora da liberdade" chegou na América, com referência ao movimento de Independências das colônias hispânicas, insere o Brasil nessa corrente como um caminho natural que viria a ocorrer. A emancipação se vincula a uma ideia de maioridade do Reino. Assim, encontramos a retórica da recolonização, sinalizando para a efetivação da Independência, e mais orientado às independências das colônias espanholas, inserindo o Brasil nesse movimento que repercute na América, a emancipação como um caminho natural e esperado das colônias ${ }^{196}$.

Em Paraguassú (1835 e 1837) a concepção de recolonização também é manifesta com a tentativa das Cortes de tolher a liberdade dos seus iguais: “- Que vale, quando tratam reduzir-nos/ Ao de Colonos primitivo opróbrio?/ Como livre dizer-se quem só urdel A seus iguais grilhão atar odioso?" 197 (grifos meus). O contexto parece expor ${ }^{198}$ as intenções dos decretos das Cortes Portuguesas sobre o Brasil, então Reino Unido a Portugal, com a menção a redução vergonhosa de seus habitantes a posição de colonos.

\footnotetext{
${ }^{196}$ No capítulo 3, momento em que analiso concepções de história, são descritos os versos que tomam as independências das colônias espanholas como exemplo da história para o Brasil.

${ }^{197}$ Ladislau dos Santos TITARA, op.cit., p.175.

198 Digo que parece expor pois o discurso está ambíguo, não foi possível identificar se a fala se refere à continuação do discurso dos brasileiros, ou resposta dos portugueses. Me parece pelo conteúdo que se trata da continuação do discurso brasileiro, mas na página anterior há uma quebra de página e começa o longo trecho que transcrevo na sequência, o que sugere que se inicia ou uma resposta ou outra pessoa falando. A princípio interpretei que não faria sentido portugueses se referirem a "grilhões atados a seus iguais" como consta, pois normalmente essa é uma colocação de brasileiros acusando a intenção de rebaixamento do Reino a status de colônia, ou "recolonização" com os decretos das Cortes portuguesas, lembrando que o Brasil era Reino Unido a Portugal, portanto iguais. Entretanto, a frase que antecede "como livre dizer-se quem só urde/ A seus iguais grilhões atar odioso?", faz entender que pode se tratar do discurso-resposta dos portugueses, sobretudo pela colocação "como livre dizer-se quem", ou seja, como alguém pode se dizer livre (os brasileiros) atando grilhões a seus iguais. Justamente pelo discurso empregado ser muito recorrente dos brasileiros, e como não há indicação no poema da voz que o profere, considero ambíguo. Assim, caso se trate da resposta dos portugueses, então pode ser uma referência á prisão de portugueses na Bahia. Segue o longo trecho: " - Nos era estranho acaso, (acesos teimam)/ Este que agora, despejado arrojo!/ Comandar ambiciona, quando aquele/ Nos riscos se incutira? Quais os feitos, Por onde ao jus se deu da estima nossa?/ Responde-nos feliz, décima Aurora/ De fevereiro eterno! Mas que monta,/ Contra atroz pertinácia, a sã Verdade? Que vale, quando tratam reduzir-nos/ Ao de Colonos primitivo opróbrio?/ Como livre dizer-se quem só urde/ A seus iguais grilhão atar odioso? O câncer extirpai, que a Pátria rói:/ Solapados rastilhos da Anarquia/ Deixam já divulgar medonho fumo,/ Onde os terços se envolvem Lusitanos./ Vedem-se, inda não tarde, ao Berço os males;/ Vedem-se, enquanto as filas Brasileiras,/ A quem premeditadas enfraquecem/ Crebras escusas, que franqueara o Acinte,/ Tendo ás armas voado, não quebrantam/ Da subordinação o freio, que amam." O contexto do trecho destacado se trata de um debate promovido pelo conselho do governo da Bahia composto por José Joaquim de Araújo Nabuco, que virou Barão de Itapoã, referido no poema por Itapoã; o desembargador Luiz Paulo de Araújo Basto; o senador Francisco Carneiro de Campos e o Dr. Francisco Gê Acaiaba Montezuma. Eles se negavam a entregar o comando das Armas para o General Madeira, e promoveram o debate com a Câmara, magistrados, o próprio Madeira, e homens distintos da sociedade baiana, conforme o poema. Há um longo discurso que identifico como sendo dos brasileiros, uma quebra de página, segue o discurso transcrito. Mais à frente tratando do conceito "anarquia", com este mesmo trecho, a ambiguidade que não me permite identificar a voz (portugueses ou brasileiros) também impacta na interpretação. Ladislau dos Santos TITARA, op.cit., 171-177. As possíveis interpretações demonstradas aqui, reforçam meu argumento sobre a importância do leitor (e conhecimentos que possui) e leitura(s) para interpretação das obras nessa cultura de história.
} 
Caso seja o discurso de brasileiros, como explicado em nota, é possível inferir, portanto, uma interpretação de intenção recolonizadora das Cortes. Entretanto, se for a resposta de portugueses aos brasileiros, trata-se de uma defesa contra a acusação sobre os portugueses colonos ("reduzir-nos de colonos primitivo opróbrio?"199), e o trecho "Como livre dizer-se quem só urde/ A seus iguais grilhão atar odioso?"200, se refere à prisão dos portugueses na Bahia. Considero a construção ambígua, o que torna a interpretação distinta dependendo da voz narrativa que a profere.

Uma ideia de recolonização por parte das Cortes Portuguesas também aparece em Chalaça, de José Roberto Torero:

Ocorre que, naqueles dias, a nação brasileira estava cada vez mais seduzida pelo sentimento de independência. Depois que D. João se foi, as Cortes Portuguesas foram tirando pouco a pouco os vários privilégios concedidos ao Brasil na época em que a família real aqui se achava. Os brasileiros abominavam a ideia de voltarem a ter o tratamento de colonia. $(\text { grifos meus) })^{201}$

A partir das transcrições acima, é possível inserir a discussão sobre a interpretação de uma intenção ou projeto de recolonização dos portugueses. Antonio Penalves Rocha apresenta uma valiosa análise sobre a concepção de recolonização do Brasil pelas Cortes, e como ela foi incorporada à historiografia, de forma equivocada ${ }^{202}$, e Rafael Fanni, em pesquisa de mestrado apresenta como a palavra recolonização foi manipulada nas discussões dos periódicos do Rio de Janeiro entre 1820-1822 203 . De acordo com Fanni, o emprego retórico de recolonização insere uma concepção de história magistra vitae no contexto revolucionário, pois a infere à ideia de repetição, de um retrocesso que deve ser evitado. ${ }^{204}$ Sabemos que o épico de Teixeira e Sousa foi publicado décadas depois, mas ainda na primeira metade do século XIX (1847 e 1855, respectivamente). Faz sentido, portanto, que o uso de forma notória da ideia de recolonização na construção poética da

\footnotetext{
${ }^{199}$ Ladislau dos Santos TITARA, op.cit, p. 175.

200 Ibidem, p. 175.

${ }^{201}$ José Roberto TORERO, op.cit, 1994, p.83.

202 Antonio Penalves ROCHA, A recolonização do Brasil pelas Cortes: histórias de uma invenção historiográfica. São Paulo: Ed. UNESP, 2009. Ver também o estudo sobre as discussões dos deputados nas Cortes em: Marcia Regina BERBEL, “A retórica da recolonização”.In: István Jancsó (org.), Independência: História e historiografia. São Paulo: Hucitec: Fapesp, 2005.

${ }^{203}$ Rafael FANNI, Temporalização dos discursos políticos no processo de Independência do Brasil (18201822). Dissertação de Mestrado. FFLCH-USP. São Paulo, 2015.

${ }^{204}$ Ibidem, p.4.
} 
obra apresente-se não apenas por uma elaboração retórica, mas por um entendimento de seu tempo.

A interpretação de um projeto recolonizador por parte das Cortes Portuguesas foi elevado a "fato histórico" pela historiografia ${ }^{205}$, como aponta Penalves Rocha. De acordo com o autor, em balanço geral: "pode-se sinteticamente dizer, que depois de ter sido elevada, no século XIX, à condição de fato histórico, a recolonização se alojou na historiografia do século $\mathrm{XX}$ e foi explicada conforme os diversos pressupostos que presidiriam os trabalhos dos historiadores."206

Mais de um século depois, na obra de Torero, de 1994, essa tese continua vigorando. Cabe esclarecer que não se trata de apontar erros sobre a história nas obras literárias, pois o compromisso dos escritores é outro, com a imaginação. E não se trata de defender que os escritores de literatura se baseiem na historiografia para a concepção de suas obras. Eventualmente através de pesquisas que os autores façam isso pode ocorrer. Trata-se de apontar como as interpretações da história e suas representações se manifestam nas obras, o que pode ocorrer através de intertextualidades (sejam através de discussões em jornais/periódicos, em outras obras literárias ou mesmo através do ensino) e de forma inconsciente, ou não. $\mathrm{O}$ aspecto ressaltado, dessa forma, é a cultura de história em movimento contínuo, que se manifesta nas correspondências entre a literatura e a historiografia.

Ainda em Chalaça, de José Roberto Torero, despotismo aparece empregado em outro contexto, no período em que D. Pedro abdica do trono em 1831:

Continuou, porém, no Brasil, o trabalho dos que semeavam o ódio entre brasileiros e portugueses. D. Pedro, por mais devotado que fosse nos seus esforços, tinha uma mancha original: o haver nascido português. (...) Eles só se dariam por satisfeitos no dia em que tomassem o poder, livrando-se do que denominavam despotismo estrangeiro. ${ }^{207}$ (grifos meus)

A concepção inserida no despotismo estrangeiro é de que o Brasil só se tornaria verdadeiramente independente quando se livrasse do monarca português. D. Pedro I abdicou em nome de seu filho o infante Pedro II, nascido no Brasil. Novamente, temos a influência de interpretações historiográficas acerca da Independência, mesmo que ela não

\footnotetext{
${ }^{205}$ Antonio Penalves ROCHA, op.cit, 2009, p.15-45.

206 Ibidem, p.38.

${ }^{207}$ José Roberto TORERO, op.cit., p.186.
} 
seja consciente e/ou proposital por parte do escritor. Essa é uma interpretação apresentada por Sérgio Buarque de Holanda, como mencionado no começo deste capítulo.

Em Era no tempo do rei (2007), de Ruy Castro, temos outra ideia que se relaciona a de recolonização, quando o narrador explica sobre a vinda da família real coloca da seguinte forma: “ $O$ fato de o Brasil ser a metrópole e Portugal, a colônia, provocara uma reviravolta no comércio marítimo internacional [...]"208. João Paulo Pimenta, aponta que havia uma ideia corrente no século XIX, de uma suposta "inversão de papéis" entre metrópole e colônia devido o deslocamento do centro de decisões e moradia dos monarcas para o Brasil $^{209}$. A partir de uma interpretação baseada nessa concepção se atribui um projeto de recolonização do Brasil por parte das Cortes de Lisboa, devido a suposta decadência que Portugal sofreu com a ausência dos monarcas e a invasão de Napoleão Bonaparte. Essa ideia de inversão dos papeis de Brasil e Portugal não se distancia muito da apresentada por Joaquim Gil Pinheiro, autor do épico Primícias, quando argumenta que a mudança da Coroa para o Brasil teria levado Portugal à crise ${ }^{210}$, como já apresentado anteriormente.

De forma bem distinta, A noiva da revolução (2006), apresenta outra aplicação do vocábulo, quando a narradora lembra uma frase de Domingos José Martins dizendo que "as vítimas do despotismo são a nobreza pernambucana" "211, no que se refere ao ônus dos tributos impostos pelo governo do Rio de Janeiro, uma das insatisfações que levaram ao levante.

De alguma forma também conectada às discussões referentes ao Brasil nas Cortes e reação nas províncias, há o emprego do termo anarquia. Na epopeia da Independência (1847 e 1855), de Teixeira e Sousa, como já exposto a Anarquia é personificada como um tipo de "entidade". Porém, de forma geral, a anarquia se refere às revoltas e levantes das províncias que recusavam o governo centralizado do centro-sul. O poeta esclarece: "Os bons, os sábios chamam-lhe - Anarquia -/ Chamam-lhe os maus, os néscios -

\footnotetext{
${ }^{208}$ Ruy CASTRO, op.cit, p.98.

209 João Paulo PIMENTA, A Independência do Brasil e a experiência hispano-americana (1808- 1822). São Paulo: Hucitec: FAPESP, 2015, p.390.

${ }^{210}$ Tâmis Parron aponta que a escolha pela mudança da Coroa portuguesa para a colônia não admira, pois era na América que se concentrava o eixo dinâmico da economia imperial portuguesa. $\mathrm{O}$ autor esclarece: "A América portuguesa havia atravessado um portentoso renascimento agrícola na conjuntura de expansão inflacionária da economia-mundo capitalista, chegando a fornecer entre 1802 a 1806 dois terços dos produtos exportados pela metrópole." Em: Tâmis Peixoto PARRON, A política da escravidão na Era da liberdade: Estados, Unidos, Brasil e Cuba, 1787-1846. Tese de doutorado do Programa de Pós-graduação em História Social do Departamento de História da Faculdade de Filosofia, Letras e Ciências Humanas da Universidade de São Paulo, 2015, p.155.

211 Paulo Santos de OLIVEIRA, op.cit., p.357.
} 
Liberdade -/ Inimigo do povo o povo estraga;/ Inimigo dos reis, os reis esmaga!"212. Mais claro impossível: a anarquia, tida como anseio por liberdade ou autonomia das províncias ou povo, a estes estraga. Sendo, portanto, hostil aos reis, pois acaba com seu controle e governo.

O vocábulo anarquia também é utilizado, por exemplo, quando se refere a Pernambuco, no momento em que ocorrem levantes das juntas constitucionais que se deflagraram às vésperas da Independência, e para onde seguiram tropas enviadas por D. Pedro, lideradas por Labatut: Já desdobrando as asas sanguinosas/ Em Pernambuco os vôos distendia!/ Pois entornando fúrias pavorosas/ Ali vagava o espírito d'Anarquia!"213. Em seguida discorre sobre a Bahia: “... Prorrompeu na província da Bahia,/ Entre os partidos, furibunda guerra!/ Vagueava o demônio d'Anarquia/ Por essa infausta desolada terra!/ E entre Manuel Pedro, entre Madeira ${ }^{214}$ / Tem começo essa atroz cena primeira!"215 A anarquia se manifesta pela recusa do governo das armas indicado por Portugal na figura de Madeira de Mello, dando início a uma guerra que se expande contra o domínio luso e culmina na expulsão dos portugueses em 1823.

Primícias (1900), de Joaquim Pinheiro, também narra esses levantes assim como o de São Paulo, no momento em que D. Pedro viaja para a província e no caminho declara a Independência, evento conhecido e que compõe uma memória oficial da história nacional. Entretanto, em Primícias (1900), a palavra anarquia não é utilizada, mas sim motins, sobressaltos e rebeliões ${ }^{216}$, como já analisado na primeira parte deste capítulo.

Em Paraguassú (1835 e 1837), no trecho já citado anteriormente, que infere um sentido de recolonização por parte das Cortes portuguesas, a anarquia aparece na passagem: “ - Como livre dizer-se quem só urde/ - A seus iguais grilhão atar odioso?/ O câncer extirpai, que a Pátria rói:/ - Solapados rastilhos da Anarquia/ - Deixam já divulgar medonho fumo, / - Onde os terços se envolvem Lusitanos." ${ }^{217}$ Como já explicado anteriormente $^{218}$, caso este excerto corresponda a voz dos lusos, anarquia alude ao levante na província da Bahia e a negação de permitir que o General Madeira assumisse

\footnotetext{
${ }^{212}$ Antonio Gonsalves TEIXEIRA E SOUSA, op.cit., Tomo I, p.259.

${ }^{213}$ Antonio Gonsalves TEIXEIRA E SOUSA, op.cit., Tomo II, p.103.

214 Trata-se do governador interino da Bahia Manoel Pedro de Freitas Guimarães e Ignácio Luiz Madeira de Mello que comandou as tropas portuguesas que iniciaram o confronto das lutas da Independência na Bahia. Madeira de Mello tinha sido indicado para o governo das armas da província, cargo ocupado pelo brasileiro Manoel Pedro Guimarães. A recusa da autoridade de Madeira resultou no início de uma guerra civil. Em: João Paulo PIMENTA, op.cit., 2015, p.404.

${ }^{215}$ Antonio Gonsalves TEIXEIRA E SOUSA, op.cit., Tomo II, p. 104.

216 Joaquim Gil PINHEIRO, op.cit, p. 200-202.

${ }^{217}$ Ladislau dos Santos TITARA, op.cit, p. 175.

218 Ver nota 198.
} 
o comando das Armas, conforme estabelecido pelas Cortes portuguesas. Caso seja a continuação do discurso dos brasileiros, seria "anarquia" de Portugal conceder o cargo ao luso e o envio de tropas para a província.

No romance de Torero, Chalaça (1994), encontramos o entendimento da Independência afastando a anarquia que se espalhava: "Tal fato (a declaração da Independência) será sempre memorável e glorioso, porque livrou a nação brasileira da anarquia." ${ }^{219}$. Anarquia pode ser entendida pelos levantes de algumas províncias antes da declaração de independência, ou ausência de um governo central.

Assim, é possível perceber que anarquia é associada aos movimentos que contestavam ordens de um governo centralizado. Em geral, a Independência aparece como a causa ou justificativa que poupou o Brasil de um estado de anarquia generalizado, e motivo de união das províncias. Pimenta, analisando periódicos da América portuguesa noticiando as ocorrências dos movimentos independentistas na América espanhola e o movimento pernambucano de 1817, percebeu que "anarquia, insurgência, insurreição, revolta, revolução e rebelião", funcionavam como sinônimos na designação de afronta ou subversão à ordem vigente. ${ }^{220}$

Como anarquia pode se relacionar com motins, sedições, sublevações, trataremos agora do conceito revolução.

Na epopeia de Joaquim Gil Pinheiro, Primícias (1900), revolução aparece em nota para designar a Inconfidência Mineira: "Em casa deste (Gonzaga) se faziam os conciliábulos discutindo-se os planos da revolução, sendo adotada e aprovada a forma republicana." 221 . Sobre o mesmo levante, em verso o poeta utiliza motim e rebelião: "Esta medida aos chefes desarmara,/ Por lhes tirar a base do motim;/ Maciel uma assembléia convocara/ Para à rebelião todos porem fim." 222

A Revolução de Pernambuco de 1817, também recebe o mesmo tratamento: "Nesse mesmo ano Dom João elevou/ A reino o Brasil, para ao povo agradar;/ Apesar de tal ato não deixou/ De no Recife um motim rebentar." 223 Seguindo, depois de narrar o

\footnotetext{
219 José Roberto TORERO, op.cit, p.111.

220 João Paulo PIMENTA, "A política Hispano-americana e o Império Português". In: István JANCSÓ (org.) Brasil: Formação do Estado e da Nação.São Paulo- Ijuí: Hucitec: Ed. Unijuí: Fapesp, 2003, p.123139.

${ }^{221}$ Joaquim Gil PINHEIRO, op.cit., p.175. A nota se refere ao verso: "Em congressos discutiam/ Como haviam de ficar independentes;/ Em casa de Gonzaga se reuniam/ Os chefes em geral e Tiradentes." Tratase de Tomás Antônio Gonzaga, um dos insurgentes da Inconfidência Mineira.

${ }^{222}$ Joaquim Gil PINHEIRO, op.cit., p.176. A medida refere-se a suspensão dos pagamentos atrasados do imposto (o quinto), como o autor esclarece em nota na mesma página.

${ }^{223}$ Joaquim Gil PINHEIRO, op.cit., p.186.
} 
assassinato do comandante que tentava prender Barros Lima: "Começou com este fato a rebelião"224. A palavra mais empregada é rebelião, como no caso da derrota de Artigas: "Com a submissão do exército de Artigas/ Deram por finda a rebelião platina..." ${ }^{225}$. Assim como nos levantes nas províncias às vésperas da declaração da Independência, como demonstrado anteriormente.

Teixeira e Sousa emprega revolução quando se refere a Independência da Colômbia: "-Eis da revolução da independência / Solenizava o povo o aniversário!"226.

O vocábulo também é utilizado em verso dos discursos dos deputados nas Cortes. Na manifestação de Cipriano Barata: “-Soou o grito aqui da liberdade,/ Repetiu o grito tão forte;/ E, compreendendo dela a sã verdade,/ D’outra revolução seguiu a sorte!/ Livre todo o Brasil desde esta idade,/ Guiou-se de seu bem ao fixo norte:/ Ficaram, os dois povos sublevados,/ De fato, e de direito separados." 227 No verso acima, havendo a menção à revolução que se iniciara em Portugal, depreende-se que se refere à Revolução do Porto, que se estendeu a Lisboa, e a consequente convocação do Congresso para elaboração da Constituição do Reino. O movimento brasileiro, portanto, é colocado como uma contrarrevolução, que caso as Cortes não mudassem seus planos, levaria o Brasil à Independência.

No romance de Machado de Assis, Memórias Póstumas de Brás Cubas (1880), encontramos algo diferente: trata-se da "revolução de 1831", que resultou na abdicação de D. Pedro:

O portador era casado com uma irmã do Cotrim, chegara poucos dias antes do Norte, chamava-se Damasceno, e fizera a revolução de 1831.(...) Saíra do Rio de Janeiro, por desacordo com o regente, que era um asno, pouco menos asno do que os ministros que serviram com ele. De resto a revolução estava outra vez às portas. ${ }^{228}$ (grifos meus)

Nas outras obras aqui analisadas não foram encontradas menções iguais se referindo à abdicação de D. Pedro I. Entende-se como revolução o afastamento do monarca

\footnotetext{
${ }^{224}$ Ibidem, p. 188.

225 Ibidem, p. 186.

${ }^{226}$ Antonio Gonsalves TEIXEIRA E SOUSA, op.cit., Tomo I, p.66.

${ }^{227}$ Antonio Gonsalves TEIXEIRA E SOUSA, op.cit., Tomo II, p.164.

${ }^{228}$ Machado de ASSIS, op. cit., p. 240.
} 
português, que inicia o período regencial que se estende até a Maioridade, em 1840, quando Pedro II assume na condição de monarca brasileiro.

Em Viva o povo brasileiro (1984), os que lutaram na defesa da Bahia, e da Independência são tratados como "revolucionários patriotas" 229, ou "conspiradores: "O povo brasileiro se levantava contra os portugueses e discursos caudalosos ribombavam pelas paredes das igrejas, boticas e salões onde os conspiradores profetizavam a glória da América Austral, fulcro do esplendor, fortuna e abundância."230 (grifo meu) E como sinônimo, revoltosos: "Se queria [Perilo Ambrósio ${ }^{231}$ ] que os brasileiros prevalecessem, não era por ser brasileiro - e na verdade se considerava português- (...), deliberara adquirir fama de combatente ao lado dos revoltosos." ${ }^{232}$. Ainda nos pensamentos de Perilo Ambrósio: "Muito bem, de fato a Revolução premiara seus heróis." ${ }^{233}$ E pouco adiante: "Sim, a Revolução premiou seus heróis, pensou outra vez Perilo Ambrósio, sopesando a frase, que achou elegante e expressiva." 234

Portanto, não apenas a batalha e os que nela lutaram, mas a Independência é tratada por revolução. Considerando a violência das lutas na Bahia, antecedidas por uma guerra que se iniciou quando Madeira de Mello foi indicado para ocupar o cargo de governador de armas na Bahia, resultando na expulsão dos portugueses da província depois de longo conflito, não é de se admirar que receba esse tratamento. No livro de João Ubaldo, no caso da Independência ${ }^{235}$, sempre que é evocada a palavra revolução, ela é associada às lutas que ocorreram na província. Dessa forma, fica ambígua a luta na Bahia e a Independência como revolução. Ao mesmo tempo os "revolucionários" também receberam a alcunha de "conspiradores", de forma a traduzir a efervescência de um espaço público politizado em que se espalhavam as ideias de Independência e do combate

\footnotetext{
${ }^{229}$ João Ubaldo RIBEIRO, op.cit., p.37.

${ }^{230}$ Ibidem, p. 28 .

${ }^{231}$ O personagem Perilo Ambrósio é um dos centrais de Viva o povo brasileiro. Através de uma farsa, simula ferimentos em batalha para se apresentar ao comandante das tropas brasileiras, e com isso é alçado ao estatuto de herói da Independência e da Bahia. Como recompensa recebeu o título de barão, tornandose o Barão de Pirapuama. A farsa se deu pois, para simular os ferimentos assassinou um cativo que o acompanhava, para sujar-se se sangue. Se escora em Feliciano, o outro cativo que o acompanhava e que testemunha todo o ocorrido. Para que nunca conseguisse denunciá-lo, manda cortar a língua de Feliciano. Perilo Ambrósio caracteriza os senhores de terras e escravos e uma classe dominante, era cruel e violento. Mas socialmente, tido com respeito e influência política.

${ }^{232}$ João Ubaldo RIBEIRO, op.cit., p.40.

233 Ibidem, p.48.

${ }^{234}$ Ibidem, p.49.

${ }^{235}$ Em passagem mais próxima do final do livro, na voz de um personagem defensor do regime militar a Ditadura é tratada como "Revolução": "Quando eclodiu a gloriosa Revolução de 64, ele [Ioiô Lavínio] tomou a frente da coleta de ouro para o Brasil na ilha, havendo doado pessoalmente seu anel de contador, as alianças do casal e uma pulseira relógio...”. Em: João Ubaldo RIBEIRO, op.cit., p.603.
} 
contra os portugueses, através de discursos em reuniões e de panfletos pendurados em igrejas e outros logradouros públicos.

Em outra passagem da mesma obra, ambientada em 1898, quando o filho de Maria da Fé, conhece o pai, Patrício Macário e este lhe pergunta o que faz, a resposta é:

- Faço revolução, meu pai - respondeu Lourenço. - Desde minha mãe, desde antes de minha mãe, até que buscamos uma consciência do que somos. Antes, não sabíamos nem que estávamos buscando alguma coisa, apenas nos revoltávamos. (...) Não temos armas que vençam a opressão e jamais teremos, embora devamos lutar sempre que a nossa sobrevivência e a nossa honra tenha de ser defendida. Mas a nossa arma há de ser a cabeça de cada um e de todos, que não pode ser dominada e tem de afirmar-se. Nosso objetivo não é bem a igualdade, é mais a justiça, a liberdade, o orgulho, a dignidade, a convivência. Isto é uma luta que trespassará os séculos, porque os inimigos são muito fortes. A chibata continua, a pobreza aumenta, nada mudou. A Abolição não aboliu a escravidão, criou novos escravos.(...) Mas nós estamos fazendo essa revolução de pequenas e grandes batalhas, umas sangrentas, outras surdas, outras secretas, e é isto que eu faço, meu pai. ${ }^{236}$ (grifos meus)

Maria da Fé (ou Dafé), a mãe de Lourenço, é uma personagem importante do livro. Fruto do estupro que sua mãe Venância (ou Vevé) sofreu pelo Barão de Pirapuama, era cativa que trabalhava na fazenda deste. A seu mando, foi enviada para longe, e foi trabalhar para o Nego Leléu, alforriado que após muitas dificuldades ascendeu socialmente com sua quitanda, e estabeleceu muitos negócios em diversas regiões do Recôncavo. Tornou-se oficial alfaiate e empregava outros libertos. Também abriu uma casa de prostituição, local em que colocou uma "cafetina" para gerenciar. O Nego Leléu recebeu a incumbência de levar Vevé para longe das propriedades do Barão de Pirapuama e se afeiçoou a Maria da Dafé no momento em que esta nasceu, ajudando a criá-la. Quando mais velhas, Vevé e Dafé caminhavam juntas, e encontraram quatro rapazes (brancos) que tentaram violentar Maria da Fé (lembrando que Vevé já havia sofrido um estupro pelo Barão de Pirapuama, sempre cruel e sádico com seus cativos). Na tentativa de defender a si e a sua filha, Vevé foi assassinada. A partir daí, quem cria Dafé é o Nego Leléu, e a personagem sofre uma transformação. Apesar de receber instrução decide lutar

\footnotetext{
${ }^{236}$ João Ubaldo RIBEIRO, op.cit, p.596.
} 
e se alia a Irmandade do Povo brasileiro ${ }^{237}$, em que defende seus ideais de justiça e liberdade pela defesa e dignidade do "povo", se tornando muito famosa com sua milícia passando por inúmeras batalhas, inclusive a Guerra de Canudos (1896 - 1897). A trajetória da personagem é importante para explicar quem ela representa: o grupo dos subalternos, dos oprimidos. Daí, uma explicação de revolução de forma não apenas politizada, como normalmente o é, mas engajada, militante. Portanto, o vocábulo se associa a justiça, liberdade, dignidade, orgulho e convivência. Trata-se da revolução dos subalternos contra a classe dominante e opressora, e um diagnóstico de uma luta que atravessará séculos. Por fim, o vocábulo descreve tipos de lutas, grandes e pequenas, surdas, sangrentas, secretas. Neste caso, o vocábulo revolução ganha contornos maiores e mais definidos, a partir da voz de quem o evoca e se orienta para o futuro. É uma revolução que quer subverter, transformar o presente, mas que continuará em muitas manifestações de lutas, por isso, também a referência aos tipos de revolução.

Já A noiva da Revolução (2006) abre a narrativa com uma definição de revolução na concepção de sujeitos de grupos sociais distintos:

"Revolução é uma guerra civil entre nós para acabar com a separação entre os ricos e os pobres, a discriminação das gentes de pele escura, e levar a felicidade a todas as pessoas, sem exceção de nenhuma", me disse certa vez um pobre alfaiate baiano, pardo liberto. Mas eu também ouvi de um fidalgo branco e riquíssimo que "revolução é o mais negro e abominável dos males que pode acometer um país". 238

Os dois sentidos possuem em si algo em comum, acabar com privilégios de um grupo sobre os demais, o que para o primeiro um "pardo liberto" é visto como o motivo que levaria a felicidade à todas as pessoas e fim de discriminações por raça, cor e grupo/ status social, para o outro é o exato motivo de desagrado ou infelicidade, pois essa divisão mantém seu status social e benesses. A igualdade para o último seria, fundamentalmente, o que ele e o grupo que representa não querem. A revolução é tomada como uma guerra civil, ou um dos piores infortúnios que pode atingir um país; em ambos os casos, não se

\footnotetext{
${ }^{237}$ A Irmandade do Povo Brasileiro foi criada por 3 cativos do Recôncavo, que trabalhavam para o Barão de Pirapuama, e lutava pelo povo brasileiro. Julio Dandão, um desses três cativos, possuia um item - a canastra - que continha magias e segredos (sobrenaturais) sobre o futuro. A Irmandade foi criada na Casa da Farinha que fazia parte das propriedades de Perilo Ambrósio, o barão de Pirapuama.

${ }^{238}$ Paulo Santos de OLIVEIRA, op.cit., p.11.
} 
trata de uma visão individual, mas de grupos ou países. A abertura do livro faz alusão à Revolução Pernambucana, projeto alternativo que recusou o governo central do Rio de Janeiro, mantendo a província com um governo autônomo e emancipada por cerca de três meses. Entretanto, é interessante a "fala do liberto", visto que a revolução em Pernambuco recusou o governo central devido às insatisfações pelo ônus que a província pagava para o Rio de Janeiro, um tratamento considerado desigual e daninho por parte dos insurgentes. Por outro lado, não estava no horizonte dos revolucionários a abolição da escravidão em seu projeto de governo, portanto internamente, certos privilégios e desigualdades seriam $\operatorname{mantidos}^{239}$. Assim, para que ocorresse o fim da "separação entre ricos e pobres e a discriminação das gentes escuras" seria necessária uma revolução ou guerra civil, dentro da revolução de Pernambuco de 1817 . O crivo que permite essa possível interpretação é o contraponto do pensamento de um pardo liberto e um fidalgo branco riquíssimo. A narradora encerra a citação sem explorar seus sentidos, apenas indicando que para ela "revolução" significava as duas coisas, pois esta lhe "trouxe e arrebatou a felicidade."240

Exceto na passagem acima mencionada, de forma a apontar distintos sentidos, a palavra revolução é utilizada para se referir ao nome como ficou conhecido o levante e designação dos líderes ou participantes do movimento, os revolucionários, ou revolucionários patriotas. Pimenta esclarece que homens e mulheres em 1817 sentiam as transformações observadas no universo político como produto de um tempo acelerado de mudanças. Assim, esclarece, o movimento de 1817 pôde ser assumido por todos como, "efetivamente, uma revolução no sentido moderno do termo, isto é, associado a uma subversão radical no estado das coisas tal qual até aquele momento existente."241

Em Chalaça (1994), foram encontradas menções a tumultos e revoluções na América, em referência às independências das colônias espanholas: "Como é do conhecimento do ilustrado leitor, nosso século tem sido palco de tumultos e revoluções impensáveis há cinquenta anos. Reis são decapitados, inventam-se máquinas e colônias se libertam para desespero dos cartógrafos e estudiosos da arte política."242 (grifos meus) Tumultos, revoluções e independências são utilizados de forma equivalente, de subversão

\footnotetext{
${ }^{239}$ Pimenta esclarece que embora tenha sido discutida internamente, a defesa da propriedade privada ficou em primeiro plano, o que entrava diametralmente em conflito com a possibilidade de abolição generalizada. Em: João Paulo PIMENTA, A Independência do Brasil e a experiência hispano-americana (1808-1822). São Paulo: Hucitec: Fapesp, 2015, p.279-281.

${ }^{240}$ Paulo Santos de OLIVEIRA, op.cit., p.11.

${ }^{241}$ João Paulo PIMENTA, op.cit., 2015, p.227.

${ }^{242}$ José Roberto TORERO, op.cit., p.120. Essa passagem faz parte da parte do livro do suposto diário de Chalaça, por isso o narrador se dirige ao leitor.
} 
à ordem vigente, inovações e lutas; sentidos que podem ser considerados complementares, embora distintos. Quando o narrador explica que os brasileiros "abominavam a ideia de voltarem a ter o tratamento de colônia"243, acrescenta: "Entre os brasileiros este sentimento manifestava-se em tumultos e sublevações nas diferentes províncias, e a nação corria o risco de ser sepultada num abismo de sangue caso as autoridades - digo, o Príncipe - não tomassem uma atitude." ${ }^{244}$ Em outro momento, quando se refere à viagem que D. Pedro faz a São Paulo, momentos antes da declaração da Independência utiliza o vocábulo sedição. Assim, tumulto, sublevação e sedição funcionam como sinônimos e indicam insatisfações das províncias e levantes violentos.

Assim, podemos identificar o vocábulo revolução numa acepção ampla, como sinônimo de levantes e subversão da ordem vigente, utilizados no mesmo sentido de motins, rebelião, sublevação, tumultos. Em geral, essas menções são direcionadas aos movimentos das províncias, caso de Pernambuco em 1817, e da Bahia, Minas e São Paulo nos momentos que imediatamente antecedem a Independência. Também, como visto, o vocábulo foi utilizado como sentido de "bom" e "mau", o que "traz" e o que "tira" a felicidade, que pode ser entendido pela chave de "igualdade social", dependendo do grupo a que pertence quem evoca a revolução. Se pouco utilizado para tratar a Independência do Brasil, o conceito tem adesão ampla para se referir às Independências das ex-colônias espanholas, o que é interessante, pois se há associação entre os processos revolucionários que resultaram nas Independências na América, não há esse entendimento para a Independência brasileira. Em Viva o povo brasileiro (1984), pela conexão da luta na província em 1822 e 1823 com a Independência, há o uso de revolução. Entretanto, em obra mais recente, Era no tempo do rei (2007), quando em algumas passagens são citadas as independências na América espanhola, não há utilização do termo revoluções mas é empregado "movimentos de independência", aderindo já a um tratamento mais contemporâneo. O mesmo ocorre com o uso de "transferência da Corte" e não "fuga da Corte": "Carlota sabia dos movimentos de independência que fermentavam em várias delas, principalmente em Buenos Aires - com o velado apoio da Inglaterra, tão interessada na autonomia conferida ao Brasil pela transferência da Corte portuguesa." 245 (grifos meus)

\footnotetext{
243 Ibidem, p.83.

244 Ibidem, p.83.

${ }^{245}$ Ruy CASTRO, op.cit., p.128.
} 
Se, como já apontado, é possível perceber um movimento sincrônico de conceitos, sobretudo nas obras do século XIX, que indica o entendimento tal qual "homens de seu tempo" que os aplicam nas obras, há também um movimento diacrônico, que pode acompanhar ou não a historiografia, mesmo que de forma inconsciente, pela cultura de história da qual aquela faz parte. Pimenta, ao analisar o vocábulo revolução em periódicos do Brasil que tratavam das independências das colônias espanholas no século XIX, aponta que a partir do século XVII o termo ganhou conotação política paulatinamente, mas somente a partir da Revolução Francesa em 1789, revolução passou a ser entendida de duas formas: como mudança cíclica das coisas, inclusive as políticas, e subversão total da ordem política e social, o que era inédito até aquele evento. ${ }^{246} \mathrm{Na}$ análise aqui apresentada, foi possível perceber uma aproximação entre anarquia, que se espalhava no Brasil, e revolução, como a concebida no épico de Teixeira e Sousa (publicado em 1847 e 1855), apresentado no trecho em que elabora o discurso de Cipriano Barata nas Cortes de Lisboa. Essa passagem indicava um movimento revolucionário que se iniciava devido os decretos que Portugal estabelecia para o Brasil naquele momento, que resultaria na Independência. $\mathrm{O}$ entendimento da revolução nesse momento, como já apontado, era de subversão total da ordem, porém nas obras literárias mais recentes é possível perceber a ideia da Independência como "não-revolução", ou uma Independência conservadora, o "acordo" como manifestado no Cordel da história da Independência (2008). Pimenta e Paulino 247 apontam uma "interdição" da ideia da Independência como "não-revolução" a partir de um balanço historiográfico, e demonstram que embora novas pesquisas sejam capazes de "caracterizar a profundidade e radicalismo da Independência como fenômeno histórico" 248 , tal concepção já se tornou uma tradição. Além disso, no sentido que nos interessa aqui, além de um olhar acadêmico, os autores diagnosticam uma recusa geral do brasileiro de conceber o passado do país como tendo experimentado transformações radicais da ordem vigente nas esferas políticas, sociais e econômicas, "de embates e enfrentamentos que tenham sobrepujado uma tendência histórica (cultural?) à acomodação, à negociação, ao entendimento conservador." 249 O que encontramos nas

\footnotetext{
${ }^{246}$ João Paulo PIMENTA, “A política Hispano-americana e o Império português". In: István JANCSÓ (org.), Brasil: Formação do Estado e da Nação. São Paulo: Hucitec: Ed. Unijuí: Fapesp, 2003, p.128.

${ }^{247}$ João Paulo PIMENTA \& Maria Ferraz PAULINO, "Uma revolução interditada: Esboço de uma genealogia da ideia de "não-Independência" do Brasil". In: Rogelio ALTEZ \& Manuel CHUST (eds.), Las revoluciones en el largo siglo XIX Latinoamericano. Madrid: AHILA: Iberoamericana: Vervuert, 2015, p.151-169.

${ }^{248}$ João Paulo PIMENTA \& Mariana Ferraz PAULINO, op.cit., p.168.

${ }^{249}$ Ibidem, p.167-168.
} 
obras literárias aqui analisadas, portanto, como reflexos (embora também sejam capazes de mobilizar transformações) dessa cultura de história, foi um movimento com tendência a acompanhar uma compreensão da Independência da forma como se tornou uma tradição, o movimento diacrônico.

Outros vocábulos que aplicam sentidos de formas alternativas são pátria, patriota e patriotismo. Temos o emprego dessas palavras por portugueses, pelos defensores da Independência referindo-se ao Brasil, empregos regionais como na revolução de Pernambuco de 1817 ou nas batalhas contra os portugueses na Bahia. Assim, temos a pátria dos portugueses; a pátria dos brasileiros ${ }^{250}$; a pátria dos revolucionários pernambucanos. E também as palavras correspondentes nação, nacional e nacionalista.

No épico da Independência do Brasil (1847 e 1855) de Teixeira e Sousa, quando se refere a D. João e a D. Pedro a pátria é Portugal, como mostram os exemplos, respectivamente: "- Da tão cara família rodeado,/ Saudoso do país, a quem deixara,/ Segue João ao pátrio ninho amado" ${ }^{251}$; e “- Porém Pedro, que uní-los bem deseja,/ Que ama d'antiga pátria a felicidade,/ Pelo bem do Brasil sincero almeja/Amando sua doce liberdade. ${ }^{252}$.

No épico, quando há referências ao povo brasileiro, a pátria é o Brasil: "Já em São Paulo o povo Brasileiro/ Em que Pedro ficasse, meditava;/ E como patriota verdadeiro; Concorria a por claro o que pensava:/ E já com patriótica energia/ A Junta de São Paulo se reunia." 253 Assim como, quando a voz narrativa é do poeta: "Aceita pois, Senhor, o Monumento;/ Que à Pátria erijo, se consigo tanto!/ Não tenho para erguê-lo outro instrumento/ Mais que amor da Pátria, puro, e santo!..."254

Há versos em que Portugal aparece como a mãe-pátria do Brasil, sobretudo quando são construídas ou emuladas discussões do Congresso de Lisboa: “—É preciso que a ser colônia torne,/ Que os grandes tribunais não mais compreenda,/ Que com títulos reais se não adorne,/ Que da mãe pátria só sempre dependa:/ Convém que seu ardor intenso amorne./ Que seja Portugal quem o defenda..."255

A palavra "nação" é menos utilizada no Épico da Independência (1847 e 1855): “-Não, Senhor, o Brasil qual se acha agora/ Em nação, e feliz constituído, / Pela da

\footnotetext{
250 Trataremos sobre a identidade adiante.

${ }^{251}$ Antonio Gonsalves TEIXEIRA E SOUSA, op.cit., Tomo I, p.135.

252 Ibidem, p. 148.

${ }^{253}$ Ibidem, p. 155

${ }^{254}$ Antonio Gonsalves TEIXEIRA E SOUSA, op.cit., Tomo I, p.14.

${ }^{255}$ Antonio Gonsalves TEIXEIRA E SOUSA, op.cit., Tomo I, p.143.
} 
Liberdade grata Aurora/ Tão doce, e amplamente esclarecido,/ Retroceder não pode uma só hora..."256. Aqui a "nação" é conectada à união (enquanto território), à liberdade e à ideia de Independência do Brasil. O que se torna evidente na obra, é que pátria, patriota e patriotismo são palavras amplamente utilizadas, ao contrário de nação, pouco empregada. As primeiras mobilizam identificação com sentimentos de reconhecimento e pertencimento, a segunda uma ideia de unidade. É possível dizer que a escrita do épico é patriótica, a obra é um "monumento" oferecido pelo poeta à sua pátria, à memória e à história.

Jancsó e Pimenta lembram ainda que nos debates dos deputados nas Cortes constituintes portuguesas era possível perceber que o Brasil era "uma entidade política emergente que ainda não era depositária de adesão emocional, de algum tipo de patriotismo a ele referido". ${ }^{257}$ Assim, esse patriotismo encontrado no poema de Teixeira e Sousa é um sentimento do poeta, atribuído aos personagens envolvidos no processo de Independência, e mais uma vez, não era um sentimento dos coevos da Independência. Embora façamos a ressalva ao recurso retórico empregado na epopeia, ou seja, a evocação á "pátria" e "nação" brasileira era esperada.

No épico Primícias (1900), patriotismo é empregado dos dois lados (por portugueses e brasileiros): "Apenas com algumas agressões/ Foi feita do Brasil a independência,/ Causando o patriotismo turbações/ Aos dois povos por essa divergência." $" 258$

Em Paraguassú (1835 e 1837) também é notório o emprego da palavra pátria, e há, como no épico de Teixeira e Sousa, uma construção discursiva patriótica, e relembro que o autor Ladislau dos Santos Titara lutou nos batalhões libertadores contra os portugueses na Bahia. Cito um exemplo do emprego no poema: “Oh! Quanto, Pátria Gente! Honrosa, oh! Quanto/ Ao Baiense Vindouro, em vivas cores,/ Será, de quadro tal, completa cópia." ${ }^{259}$. A construção é emocional, retórica, de identificação e proximidade, das pessoas da pátria. $\mathrm{O}$ valor retórico nos épicos é muito importante e a construção narrativa é elevada, como também é possível perceber nessa outra passagem:

\footnotetext{
${ }^{256}$ Ibidem, p. 169.

${ }^{257}$ István JANCSÓ; João Paulo PIMENTA. "Peças de mosaico"...op.cit, 2000, p.36. Citação das palavras de Lino Coutinho na sessão 06.03.1822, encontrada na obra de BERBEL, Márcia Regina. A nação como artefato: deputados do Brasil nas cortes portuguesas, 1821-1822. São Paulo: Hucitec/FAPESP, 1999.

258 Joaquim Gil PINHEIRO, op.cit, p.201.

${ }^{259}$ Ladislau dos Santos TITARA, op.cit., p.178.
} 
“Distinguem-se também Ceára, e Mello:/ Matos, Tupinambá, Luz ${ }^{260}$ e outros foitos, Q Que rendem à Nação virente glória,/ Com os adversários arcam, arcam todos/ Que de vingar a Pátria pura ardência/ No coração alojam..." ${ }^{261}$ No trecho, além de pátria há o emprego de nação, também com o mesmo efeito retórico. E como valor da época, o sentimento de luta pela pátria é ressaltado: “- Que o morrer pela Pátria é vida honrosa." ${ }^{262}$ Assim, fica claro que o uso de "pátria" apela a um discurso emocional.

Em Memórias Póstumas de Brás Cubas (1880), cito duas passagens. A primeira refere-se ao momento em que Brás Cubas retorna ao Brasil, após passar alguns anos em Portugal para estudar: "Não nego que, ao avistar a cidade natal, tive uma sensação nova. Não era o efeito da minha pátria política; era-o do lugar da infância...”263 O narrador distingue a pátria política, ou seja, o local de nascimento, do local de sua afeição, das lembranças e o lugar onde passou a infância. Em outra passagem, quando descreve outro personagem, há outro emprego: "Fomos dali à casa do Dutra. Era uma pérola esse homem, risonho, jovial, patriota, um pouco irritado com os males públicos, mas não desesperando de os curar depressa. ${ }^{264}$ Aqui, patriota tem a função de qualificar o personagem, ser patriota era uma característica importante do sujeito, que merecia destaque. O emprego dessas palavras era recorrente no século XIX, momento em que foi publicada a história de Brás Cubas, primeiro na Revista Brasileira (no ano de 1880) e no ano seguinte em livro (1881), e também o épico de Teixeira e Sousa (publicado em 1847 e 1855), o que demonstra a importância do conceito e do valor que pátria, patriota e patriotismo tinham na época.

É interessante perceber que se pátria, patriota, nação eram termos muito usados no século XIX, parece que foram caindo em desuso. Em Era no tempo do rei (2007) de Ruy Castro, embora possua características muito distintas de construção e tema, pátria é usado quando se refere a ciganos, ao introduzir uma personagem: "Ouvira dizer que os ciganos podiam ser portugueses, espanhóis ou húngaros, mas não tinham pátria e nunca morriam na cama onde haviam nascido." ${ }^{265}$ Aqui, o emprego da palavra é bem específico,

\footnotetext{
${ }^{260}$ Conforme notas do poema: "Ceára" refere-se ao tenente Antonio Correia Ceára, do Batalhão de Pernambuco; "Mello" é o capitão Thomaz Pereira da Silva e Mello, comandante do Batalhão de Pernambuco (graduado em Major); "Matos" é Francisco José de Mattos Ferreira Lucena, capitão da Legião da Bahia; "Tupinambá" é o alferes de Mavorte José Venâncio Ribeiro Tupinambá ; e "Luz" é Epifanio Ignacio da Luz, tente de Caçadores do Rio. Em: Ibidem, op.cit., p.139.

${ }^{261}$ Ladislau dos Santos TITARA, op.cit., p.139. Foram mantidos os grifos do autor nos nomes próprios e a ortografia da época.

${ }^{262}$ Ladislau dos Santos TITARA, op.cit., p.129.

${ }^{263}$ Machado de ASSIS, op.cit, p.102.

${ }^{264}$ Ibidem, p. 134.

${ }^{265}$ Ruy CASTRO, op.cit, 2007, p.203.
} 
distinguindo que embora não fossem brasileiros, os ciganos não possuíam vínculo com nenhum lugar.

Em Chalaça (1994), é mais utilizado o termo nação: “...contentem-se com a narração de uma ocorrência extraordinária que mudou os destinos da nação brasileira..." 266 ; ou “...logo o Imperador começou a enfrentar os nada pequenos problemas de uma nação recém-nascida." ${ }^{267}$ Em um capítulo que se passa em Portugal no contexto de disputa do trono português entre D. Miguel e D. Pedro, o que configura o momento presente do narrador, ocorria uma conversa sobre a luta entre os irmãos e na "voz" de Caetano Gamito aparece o emprego de "solo pátrio" (no enredo este personagem substituía o Chalaça quando este se ausentava, atuando como secretário de D. Pedro), como segue: “- Mal conseguimos nós lançar a semente sagrada do liberalismo no solo

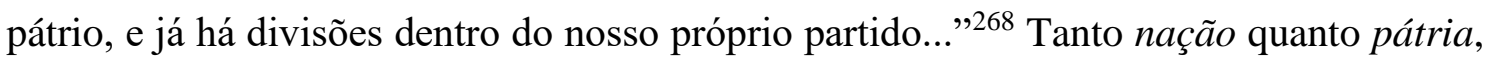
são palavras pouco empregadas, mas a primeira é mais utilizada que a segunda, mesmo quando os personagens se referem ao próprio país de origem. Assim, nação parece ser empregada com o sentido de unidade, correspondendo a Estado.

No caso pernambucano, por exemplo, como já demonstrado em pesquisas, patriota era aquele que defendia a Revolução, o governo autônomo, e o projeto republicano que ali se desenhava em 1817. Em passagem de Olhos Negros (2009), de Maria Cristina Albuquerque, além da "pátria pernambucana", é projetado o que era a pátria-mãe, de forma mais específica para dois personagens. Nesta passagem a narradora explica a influência de Manuel Arruda da Câmara sobre o Padre João Ribeiro, mas pontua as diferenças entre ambos a partir da definição ou consideração do que era a pátria-mãe para cada um:

Para Arruda, a pátria-mãe eram os sertões pernambucanos e a amante, a ciência da natureza e a liberdade dos povos. Para Ribeiro, a ideia de pátria se associava ao chão de Tracunhaém e ao Recife, bafejado pelas ricas brisas libertárias do quebra-mar. A paixão de sua vida era a pátria independente... (grifos meus) ${ }^{269}$

Se o conceito de pátria é uma designação própria dos revolucionários e ao projeto independente pernambucano, nessa passagem, associa-se a uma identificação mais

\footnotetext{
${ }^{266}$ José Roberto TORERO, op.cit, 1994, p.101.

${ }^{267}$ Ibidem, p. 119.

268 Ibidem, p.63.

${ }^{269}$ Maria Cristina C. de ALBUQUERQUE, op.cit., p.144.
} 
específica dentro da província, relacionada a uma afetividade com algumas regiões. E pátria independente se refere à província e não ao Brasil, como a pátria independente que aparece em Teixeira e Sousa, por exemplo.

Em A noiva da revolução (2006), há episódio didático sobre o emprego de patriota, explicado na "voz" de Domingos José Martins:

E como finalmente entrávamos na Era Republicana - o tempo de simples cidadãos -, deveríamos acabar com o uso das distinções de categoria social. Em vez do "Vossa Mercê" ou "Vosmecê", dirigido às pessoas tidas como importantes, por exemplo, eu propus fazermos uso geral do "Vós"; e no lugar do "Senhor", utilizarmos o termo "Patriota". Eles equivaliam aos tratamentos de "Cidadão" e "Tu", empregados durante a Revolução Francesa. ${ }^{270}$

Em Olhos Negros (2009) há passagem semelhante: "O tratamento escolhido foi simplesmente "vós". Nada havia sido concluído sobre o uso dos nomes "cidadãos" ou "patriotas". 271

Embora discordantes, nos dois casos acima há uma tentativa de esclarecimento sobre o emprego do termo, e em ambas as obras o uso de pátria e patriota foram adotados de forma ostensiva. Em geral, de maneira mais perceptível, o emprego de nação ou nacionalista se refere ao Brasil como um modo mais marcado de diferenciação. A exemplo do que aparece em A noiva da revolução (2006):

Fazer o velho Rego aceitar - até mesmo, entender - um sistema social nivelador seria querer demais. Provocar o seu orgulho nacionalista, porém, não foi muito difícil.

- Nascer brasileiro deixará de ser um título de inferioridade!... - O capitão estava com a moléstia no couro. - Se eu soubesse em quais veias me corre o sangue europeu, eu mesmo as sangraria para me desinfetar!... ${ }^{272}$

\footnotetext{
${ }^{270}$ Paulo Santos de OLIVEIRA, op.cit, 2006, p.98.

${ }^{271}$ Maria Cristina C. de ALBUQUERQUE, op.cit, 2009, p.95.

272 Paulo Santos de OLIVEIRA, op.cit., p.156. Nesse episódio Maria Teodora narra sobre a adesão de João Batista do Rego, chefe local, à causa da revolução de Pernambuco. Questões sobre identidade serão tratadas adiante.
} 
É interessante o emprego de nação nas obras sobre a revolução de 1817, pois não existia na época essa identidade ou tratamento relativo ao Brasil. Fazia pouco tempo, inclusive, que este havia sido elevado a Reino, unido a Portugal e Algarves (em 1815).

Em outro trecho em que a narradora discorre sobre a derrota da Revolução, ela diz: “...outros afirmaram que os revolucionários quiseram copiar o modelo dos Estados Unidos, esquecendo que se pode importar a lei, mas não o espírito de uma nação."273 (grifos meus) Nesse momento as Treze Colônias já haviam declarado sua independência, portanto, faz mais sentido o emprego do termo. Quanto ao "orgulho nacionalista", é importante lembrar que haviam muitas identidades em disputa naquele momento (1817), como os brasileiros (ou" naturais da terra"), os portugueses da metrópole e portugueses da América, além das identidades provinciais a exemplos dos pernambucanos, os filhos das minas, paulistas, etc, conforme nos explicam Jancsó e Pimenta. ${ }^{274}$ Dessa forma, naquele período não é possível inferir um latente sentimento nacionalista no Brasil. O "orgulho nacionalista" do romance se refere ao Brasil, entretanto, em 1817 não existia essa concepção ou identificação de nação brasileira. Todavia, os dois romances sobre a denominada Revolução Pernambucana possuem um tratamento pedagógico sobre a história, às vezes até incluindo críticas à versões da historiografia.

Dentre as obras aqui analisadas publicadas no século XX, em Viva o povo brasileiro (1984) de João Ubaldo Ribeiro é notório e frequente o emprego de pátria (e seus derivados) e nação. Encontramos a palavra pátria em passagens como: “... [o Alferes Brandão Galvão] já tinha o nome exaltado onde quer que houvesse revolucionários patriotas reunidos..."275; ou "...aquele que, na esteira de incontáveis sofrimentos e tribulações, lutando pela Pátria..."276; “...não podia, em nome da Pátria e do povo que fizera a Revolução, esconder a conduta inimiga do pai..."277; “...pois que apenas cumpri o meu dever de patriota..." 278 . Nessas passagens, os "revolucionários patriotas" eram os que lutaram contra os portugueses comandados por Ignácio Madeira de Melo na Bahia entre 1822 e 1823, e a referência à pátria também orbita na esfera da defesa do Brasil que havia declarado sua Independência. Aqui as referências se conectam diretamente ás lutas e defesa da Independência do Brasil. Em outro trecho que se passa em 1877 na narrativa,

\footnotetext{
${ }^{273}$ Paulo Santos de OLIVEIRA, op.cit, p.375.

${ }^{274}$ István JANCSÓ \& João paulo PIMENTA, "Peças de um mosaico: ou apontamentos para o estudo da emergência da identidade nacional brasileira”. In: Revista de História das Ideias, v.21, 2000, p.389-440.

275 João Ubaldo RIBEIRO, op.cit., p.37.

276 Ibidem, p.47.

277 Ibidem, p.48.

${ }^{278}$ Ibidem, p. 123.
} 
na voz de outro personagem temos uma definição: "A Pátria é a família amplificada, pensou, com orgulho por saber de cor trechos e mais trechos de Ruy [Barbosa]." ${ }^{279}$. Pátria aqui não se conecta à Independência, mas a uma consideração, a um sentimento de pertencimento, a uma "família coletiva", uma "comunidade imaginada" 280.

O emprego das palavras nação e nacional é diverso: “[...]passando os bens muito justamente confiscados a pertencer ao filho varão, distinto pelo denodo empenhado na causa nacional." 281 Outro exemplo do uso do vocábulo "nacional": "Pirapuama, nome que afirmava a singularidade nacional, que proclamava orgulhoso sua origem austral, atada àquelas terras e a seus habitantes originais..." ${ }^{282}$. Em outro excerto temos o emprego de nação: “...mas receio poder demonstrar que, sem o recurso a uma política completa para a Nação..." ${ }^{283}$. Por fim, destaco mais um exemplo do uso de nação:“[...] dos homens como eu, que no ostracismo carregam a Nação às costas!..." ${ }^{284}$. Em Viva o povo brasileiro (1984), as palavras nação e nacional são utilizadas em discursos politizados dos personagens, e pátria e patriota, como já destacado, são utilizadas em referência à defesa do Brasil nas lutas da Independência. Apenas quando o narrador discorre sobre o nome Pirapuama, que se refere ao título que o personagem Perilo Ambrósio recebe (torna-se o Barão de Pirapuama como recompensa por supostamente ter lutado contra os portugueses), e o local do Recôncavo Baiano, há uma vinculação às origens nacionais indígenas, daí a “singularidade nacional”. E a “causa nacional” se refere á Independência.

O Cordel da história da Independência (2008), que de uma maneira provocativa faz críticas ao processo de Independência, interpretada esta como um acordo, faz um emprego interessante de um sentimento patriota, pois se refere aos portugueses e não ao Brasil. Na parte que trata das lutas na Bahia, escreve que os portugueses lutaram por patriotismo: "As lutas de "independência"/ Ocorreram na Bahia,/ O português inocente,/ De amor á pátria reagia,/ Desconhecendo o acordo/ secreto que então havia." ${ }^{285}$ No último verso do Cordel, depois de discorrer sobre a necessidade de conscientização da "gente brasileira", com uma perspectiva de engajamento para o futuro evoca a "pátria brasileira": "Vamos sem pensar no fruto,/ Quem vai dele usufruir,/ Plantar a árvore da pátria,/ Todo

\footnotetext{
279 Trata-se do personagem "Ioiô Lavínio". Ibidem, p.612.

${ }^{280}$ Expressão empregada na concepção de Benedict ANDERSON, Comunidades Imaginadas: reflexões sobre a origem e a difusão do nacionalismo. São paulo: Companhia das Letras, 2008.

${ }^{281}$ João Ubaldo RIBEIRO, op.cit, p.40.

282 Ibidem, p.48.

${ }^{283}$ Ibidem, p. 133.

${ }^{284}$ Ibidem, p. 125.

${ }^{285}$ Luzimar Medeiros BRAGA, op.cit., p.15.
} 
dia ver subir,/ Majestosa tremulando,/ A bandeira do porvir." ${ }^{286}$ De forma metafórica, a árvore da pátria ainda precisa ser plantada e cultivada, com a conscientização do povo para então crescer majestosa. Mais uma vez, o recurso a palavra pátria como valor retórico é utilizado.

A palavra pátria, portanto, parece mobilizar retoricamente a identidade de pertencimento e afeto por uma região, seja por consideração ou por nascimento, e muito evocada, sobretudo, nas obras do século XIX, período em que a identidade nacional estava em formação e consolidação. Ao longo do tempo tornou-se mais comum o emprego do termo nação do que do vocábulo pátria, este muito utilizado no século XIX. A partir do século XX, muitas vezes nação corresponde a Estado ou país, embora também seja empregado com sentido de destacar identidade e pertencimento a um local.

Por fim, o emprego e os sentidos em torno do vocábulo liberdade, palavra tão prenhe de significados dependendo de quem a emprega: liberdade para o Brasil frente a Portugal; liberdade das províncias frente ao jugo centralizado de D. João e ônus do Rio de Janeiro; liberdade de atuação e comércio para a classe dominante e políticos das províncias brasileiras; liberdade para os escravizados. Estes são alguns exemplos das discussões e sentidos que a palavra recebe. Eis uma palavra que insere significados não apenas distintos mas que correspondem a conflitos de interesses. A liberdade embora empregada de forma ampla retoricamente, não era para todos. Mesmo no caso do projeto republicano da revolução de Pernambuco de 1817, embora tenha sido discutida, a liberdade para os escravizados não estava incluída, gerando conflitos e demonstrando um ponto sensível no projeto. É muito interessante acompanhar como esse conceito é utilizado nas obras literárias e como ganha sentidos diversos conforme o voz ou grupo que o empregava, como será apresentado a seguir.

Na epopeia de Teixeira e Sousa, Independência do Brasil (1847 e 1855), liberdade foi utilizada de forma personificada, como "entidade", tal qual o Despotismo (como explicado anteriormente), “- Havia já três séculos que plantara/ N’América seu sólio a Iniquidade,/ Quando outra vez dos céus gentil baixara/ Apavonada a casta Liberdade!..." ${ }^{287}$. E em emprego mais corrente “ - De amor da liberdade assás já dado/ Tinha todo o Brasil provas veementes..."288; ou ainda, "Fez o Brasil a sua Independência,/

\footnotetext{
286 Ibidem, p.20.

${ }^{287}$ Antonio Gonsalves TEIXEIRA E SOUSA, op.cit, Tomo I, p.139. A ortografia original foi mantida.

${ }^{288}$ Antonio Gonsalves TEIXEIRA E SOUSA, op.cit., Tomo II, p.294.
} 
E firma sua nobre Liberdade!"289 Também em palavra correspondente livre: "Quando livre quer ser um nobre povo/ Não há p'ra o suplantar sistema novo." ${ }^{290} \mathrm{O}$ contexto do trecho se refere ás intenções das Cortes Portuguesas, e o povo seria o brasileiro, identidade utilizada de forma abrangente. Assim, o vocábulo liberdade está diretamente ligado à ideia de Independência, e do jugo "despótico", "tirânico" português.

Em Primícias (1900) além de liberdade temos algumas palavras correspondentes, e que aparecem na parte do poema que trata da Inconfidência Mineira : “ Já nos fins do anterior século havia/ Planos da Independência do Brasil;/ A liberdade já o povo a queria,/ Ainda que a maioria a achasse hostil." ${ }^{291}$ Trata-se do ano de 1789, e no verso é atribuído um desejo de Independência do Brasil, mas o paratexto (as notas de rodapé) esclarece o desejo de "libertar a capitania do jugo português" ${ }^{292}$. Nos versos seguintes encontramos "Vendo as rendas de seu país declináveis,/ Libertá-lo queria de Portugal."293 A ideia de liberdade da província e do Brasil se confundem, e embora nas notas o autor explique melhor que se tratava da capitania de Minas Gerais, nos versos escreve como se fosse um plano de Independência do Brasil, já em 1789.

Em Paraguassú (1835 e 1837) encontramos um emprego de liberdade referindose ao Brasil, e a defesa da liberdade que Portugal ameaçava: “ - Sabeis, que a Liberdade, se perdida,/ - Aqueles, que deixou, jamais revoa."294. Em outro trecho: “ - De fraterna igualdade á reste foge:/ Sim, perca-se a união, mas não se perca,/ Brasil, o timbre teu, a Liberdade." 295 . Destaca-se a perda da igualdade com Portugal, e por isso a defesa da liberdade, uma insígnia, honra ${ }^{296}$ que o Brasil não deve perder.

Em outro verso: “... Mandou (assim que à Fama certo dera)/ A saudar o Brasil, porque vereda/ Endereçando já de Nação livre,/ Com prelúdio feliz, seguras bases/ Dispunha a Independência.”297. No último destaque, as bases da Independência já resguardadas davam como certo o Brasil como nação livre. Portanto, o conceito é

\footnotetext{
${ }^{289}$ Ibidem, p.298.

${ }^{290}$ Antonio Gonsalves TEIXEIRA E SOUSA, op.cit., Tomo I, p.168.

${ }^{291}$ Joaquim Gil PINHEIRO, op. cit., p.173.

292 Ibidem, p. 174.

${ }^{293}$ Joaquim Gil PINHEIRO, op.cit., p.174. No verso anterior o poeta havia citado José Alves Maciel, e nas notas esclarecia que este havia voltado da Inglaterra e França influenciado pelas ideias liberais que lá se espalhavam ("movimento livre dos povos") e pela independência dos Estados Unidos (que o autor aponta como ocorrida em 1781 com reconhecimento pela Inglaterra em 1783), e segue esclarecendo que a intenção de Maciel era "libertar a capitania do jugo português".

${ }^{294}$ Ladislau dos Santos TITARA, op.cit., p. 129.

295 Ibidem, p.402.

${ }^{296}$ Em: Luiz Maria da Silva PINTO, Diccionário da língua brasileira. Ouro Preto: Typographia de Silva, 1832, timbre significa: s.m.A insígnia que se põe no elmo sobre o escudo de armas. Fig. [sic] Honra.

${ }^{297}$ Ladislau dos Santos TITARA, op.cit., p.78.
} 
manipulado na oposição entre Portugal e Brasil, e luta e para defender a independência do Brasil como nação livre.

Memórias Póstumas de Brás Cubas insere um uso distinto do conceito liberdade. Trata-se do episódio em que após a morte do pai de Brás Cubas, sua família fazia a divisão da herança. Quando o cunhado de Brás Cubas diz que quer ficar com os escravizados Paulo e Prudêncio, propriedade do falecido, o protagonista esclarece que o último já havia recebido alforria:

- Bem; fico com o Paulo e o Prudêncio.

- O Prudêncio está livre.

- Livre?!

- Há dois anos.

- Livre?! Como seu pai arranjava estas cousas cá por casa, sem dar parte a ninguém! Está direito. Quanto a prata... creio que não libertou a prata? ${ }^{298}$ (grifos meus)

No caso do escravizado a liberdade é questionada e recebida com espanto e contrariedade, algo que incomoda o Cotrim, cunhado de Brás Cubas. E a liberdade do pai de Brás Cubas que alforriou Prudêncio também é questionada, conforme a última fala. No que se refere ao trato de escravizados, a liberdade concedida ao cativo e daquele que forneceu a alforria causam insatisfação e objeções.

Anos depois, andando pelo Valongo, Brás Cubas reencontra Prudêncio e segue-se a cena em que castigava com vergalhadas um cativo que cuidava de sua quitanda quando se ausentava:

Parei, olhei... Justos céus! Quem havia de ser o do vergalho? Nada menos que o meu moleque Prudêncio - o que meu pai libertara alguns anos antes.

Cheguei-me; ele deteve-se logo e pediu-me a benção; perguntei-lhe se aquele preto era escravo dele.

- É, sim, nhonhô.

- Fez-te alguma cousa?

- É um vadio e um bêbado muito grande. Ainda hoje deixei ele na quitanda, enquanto eu ia lá embaixo na cidade, e ele deixou a quitanda para ir na venda beber.

\footnotetext{
${ }^{298}$ Machado de ASSIS, op.cit., p.150.
} 
- Está bom, perdoa-lhe - disse eu.

- Pois não, nhonhô. Nhonhô manda, não pede. Entra para casa, bêbado. ${ }^{299}$

(Grifos meus)

A cena se passa em praça pública. Quando o castigado reclama e geme, Prudêncio usa a mesma frase que Brás Cubas usava quando o fazia de "brinquedo" na infância (como um cavalo em quem montava): "Cala a boca, besta!"300. Dá-se a entender que neste momento Cubas reconhece o seu menino (sua propriedade), e se aproxima. Prudêncio, já alforriado, tem os mesmos hábitos de quando trabalhava para a família Cubas, pedindo a benção ao ex-senhor, numa atitude servil. O algoz anterior, Brás Cubas, é o pacificador dessa cena, auto-retratado como bom e piedoso, pedindo que o escravo fosse perdoado. Para fechar o episódio, a atitude servil, de um ex-escravizado que não assimilou a liberdade e continua tratando Brás Cubas como seu senhor: "Nhonhô manda, não pede"301.

Ao fim dessa passagem, Brás Cubas fica a pensar no que se passou:

Era um modo que o Prudêncio tinha de se desfazer das pancadas recebidas - transmitindo-as a outro. Eu, em criança, montava-o, punha-lhe um freio na boca, e desancava-o sem compaixão; ele gemia e sofria. Agora, porém, que era livre, dispunha de si mesmo, dos braços, das pernas, podia trabalhar, folgar, dormir, desagrilhoado da antiga condição, agora é que ele se desbancava: comprou um escravo, e ia-lhe pagando, com alto juro, as quantias que de mim recebera. Vejam as subtilezas do Maroto! $!^{302}$

Machado apresenta a perspectiva da liberdade não assimilada. Apesar de forro, por passar a vida toda como escravizado, desde sua infância, Prudêncio mantém uma postura servil frente a Brás Cubas, seu antigo senhor. Há também uma dimensão de representação sobre o escravizado forro, que possuía um homem escravizado e o tratava de forma cruel, da mesma maneira que foi tratado por seus senhores, como uma pedagogia da brutalidade e da violência. Na visão do protagonista, esse era o modo que Prudêncio encontrou de descontar o que sofreu, na mesma medida em que emerge uma naturalização da violência.

\footnotetext{
${ }^{299}$ Machado de ASSIS, op.cit, p.195.

${ }^{300}$ Ibidem, p. 195.

${ }^{301}$ Ibidem, p. 195.

${ }^{302}$ Ibidem, p. 196.
} 
E nessa postura de homem de uma classe dominante, Brás Cubas de certa forma elogia essa atitude de Prudêncio: "vejam as subtilezas do maroto!".303

Em Viva o Povo brasileiro (1984), cujo enredo centra não apenas na formação do Brasil independente mas também nos projetos e visões dos grupos em conflito, ou seja, uma classe dominante e o povo, a liberdade é tematizada com algumas nuances. Temos a luta pela liberdade e independência na Bahia, e a tematização do que era a liberdade para os escravizados.

Quando o narrador discorre sobre as premiações oferecidas aos que lutaram pela Independência, encontramos expressões como “...os que suportaram, nos ombros infatigáveis, o fardo de conduzir o povo à vitória pela liberdade e felicidade." ${ }^{304}$, ou “...benesses mais fartas e generosas que a própria terra bendita sobre a qual se desdobrava agora o manto da liberdade." ${ }^{305}$ Assim, liberdade é entendida de maneira abrangente, a liberdade da terra, a liberdade do Brasil.

De modo diverso, o conceito é atribuído em outra perspectiva quando o narrador discorre sobre a morte do personagem Júlio Dandão: “ [Dandão] sabia que a liberdade de um não era nada sem a liberdade de todos e a liberdade não era nada sem a igualdade e a igualdade há que estar dentro do coração e da cabeça, não pode nem ser comprada nem imposta." 306 (grifos meus) E o negro Leléu, que criou Maria da Fé (Dafé) ${ }^{307}$, já no fim da vida resolve presenteá-la:

E, quanto a ela, agora não tinha mais desculpa para não fazer o que achava que devia fazer, que, aliás, fizesse isso mesmo: o que achava que devia fazer. Era um presente em que ele tinha pensado muito antes de dar a ela e era um presente de grande amor. Não o dinheiro, que ele não tinha ninguém no mundo a não ser ela e, portanto, era sua obrigação cuidar dela direito, pois ela tampouco tinha alguém por si no mundo. Mas, sim, a liberdade de ser e escolher, coisa para que, pelo menos da parte dele, ela acharia ajuda, embora

\footnotetext{
${ }^{303}$ Ibidem, p. 196.

${ }^{304}$ João Ubaldo RIBEIRO, op.cit, p.49.

${ }^{305}$ Ibidem, p. 49.

${ }^{306}$ Ibidem, p.316.

${ }^{307}$ Como já explicado, Maria da Fé ou Dafé, foi fruto do estupro que Venância (Vevé) sofreu, praticado por Perilo Ambrósio, o Barão de Pirapuama. Logo depois do estupro foi enviada para longe da fazenda, e anos depois quando Vevé e Dafé caminhavam juntas e encontraram um grupo de quatro rapazes brancos que tentaram violentar a filha, Vevé lutou para defender ambas, e foi assassinada. Por esse motivo o velho Leléu criou Dafé.
} 
fosse encontrar dificuldade de todas as outras partes, dificuldade mortal mesmo, dificuldade dura e sem misericórdia. ${ }^{308}$ (grifos meus)

Nos dois trechos, temos bons exemplos do que era o valor da liberdade na voz de escravizados que ganhavam alforria, cuja liberdade era constantemente questionada, mesmo quando livres. As relações com brancos (a partir desses) continuavam muitas vezes com a dinâmica de tratamento subalterno, servil. Portanto, o "presente" que Leléu oferece a Dafé, é seu bem mais precioso, a liberdade. Mesmo tendo consciência que ela encontraria "dificuldade mortal" para usufruí-la, para ser e optar fazer o que quisesse. E para Júlio Dandão, que fazia parte da Irmandade Povo Brasileiro, e conseguiu sua alforria lutando na Guerra dos Farrapos (1835-1845), de nada adiantava a liberdade, se não fosse para todos, e de nada serviria essa se não houvesse igualdade entre as pessoas, na sociedade. Mas igualdade, para o personagem, era um valor/consideração que o sujeito possui ou não (para si e no trato com outros), que não pode ser determinada ou comprada. Embora livre, Dandão, continuava sendo tratado como inferior, e sua liberdade era questionada e até desacreditada. Estes foram apenas dois exemplos sobre o modo como, no romance, liberdade era utilizada na voz dos escravizados.

Em mais um trecho a liberdade não é colocada sozinha, mas caminha junto da ideia de justiça e dignidade, como em tantos outros momentos na narrativa: “[Zé Popó] ...teria orgulho se essa luta tivesse sido, como poderia ser, para defender um Brasil onde o povo governasse, um grande país, uma grande Pátria, em que houvesse dignidade, justiça e liberdade!" ${ }^{309}$ Liberdade, portanto, nos três excertos destacados é utilizada de maneira politizada e qualificada, e dificilmente a palavra é utilizada sozinha. Nesses casos, a liberdade vem acompanhada de igualdade, justiça, dignidade, ter escolha para ser e fazer o que quiser.

No romance de Paulo Santos de Oliveira, A noiva da revolução (2006), se havia o propósito de liberdade para a província, a liberdade para os escravos foi um ponto sensível e discordante do projeto republicano ${ }^{310}$. Se almejado por alguns dos que participaram da cúpula do movimento, não entrou na pauta do que se desenhava, devido a defesa da propriedade privada e apoio de proprietários de terras ao movimento. Portanto, a liberdade não era para todos. O romance possui um capítulo dedicado a essa questão, e

\footnotetext{
308 João Ubaldo RIBEIRO, op.cit., p.378.

${ }^{309}$ Ibidem, p.476. Discurso de Zé Popó, considerado herói de Pátria, por ter lutado na Guerra do Paraguai.

${ }^{310}$ Paulo Santos de OLIVEIRA, op.cit., p.135-140.
} 
apresenta as discussões em torno da abolição pelos revolucionários no projeto republicano de Pernambuco, e os motivos pelos quais não vigorou. ${ }^{311}$

A narradora, Maria Teodora, alega que os monarcas não tinham tanto medo da República, mas sentiam pavor da possibilidade dos cativos se juntarem ao movimento: “enquanto os negros não tomassem parte da luta o perigo seria relativamente escasso, mas se os escravos se juntassem ao movimento, pela consciência da sua força ou pelo desejo de liberdade, a ruína seria incalculável."312 (grifo meu) E caso a emancipação dos escravos fosse colocada no projeto, o movimento perderia o apoio dos senhores de terras da região.

Em Olhos Negros (2009) encontramos passagens como: “Até aquele dia fatídico (06 de março de 1817), vivera vida principesca. Sonhava com uma pátria liberta e justa." 313 (grifos meus). Neste caso, o vocábulo é utilizado de maneira genérica para se referir ao Brasil, e liberdade vem acompanhada de justiça. Quando Maricotinha, a narradora, discorre sobre a proibição de sepultamento de Abreu e Lima no Recife, descreve que ele "defendera a liberdade das Américas" 314 , e que com a negativa do enterro "gemeram os ideais patrióticos e libertários que cultivamos por anos tão difíceis." 315 . Na segunda passagem, liberdade se refere às colônias espanholas da América e a Pernambuco, respectivamente. Nesse romance, quando há referência no projeto da revolução sobre a abolição dos escravizados, a palavra escolhida é emancipação.

A narradora, Maricotinha, conta que Luís do Rego foi capitulado, assumindo a presidência da província Gervásio Pires. Em 1821, iniciava-se um movimento em prol do regime constitucionalista:

Estávamos livres e não tivemos tempo de acreditar na novidade! Era estranho imaginar que estivéssemos desvinculados tanto de Lisboa quanto do Rio de Janeiro. A Revolução Constitucionalista do Porto levou as Cortes a voz retumbante de Muniz Tavares e a palavra contundente de Cipriano Barata. ${ }^{316}$ (grifos meus)

\footnotetext{
${ }^{311}$ Trata-se do capítulo VI. Paulo santos de OLIVEIRA, “A questão dos negros”, op.cit., p.135-147.

312 Paulo Santos de OLIVEIRA, op. cit. , p.192.

${ }^{313}$ Maria Cristina C. de ALBUQUERQUE, op.cit., p.29.

314 Ibidem, p.23.

${ }^{315}$ Ibidem, p. 24

${ }^{316}$ Ibidem, p. 118.
} 
O uso da palavra livres do trecho acima, se refere a uma ideia de independência ${ }^{317}$, a primeira de Portugal e a segunda do governo central do Brasil.

No Cordel da história da Independência (2008), o emprego de liberdade se diferencia, se atrela aos ímpetos libertários da Inconfidência Mineira e a recusa de uma Independência acordada. De acordo com o cordel a "grande gestão de D. João"318, que promoveu muitas transformações no Rio de Janeiro decorreu de pressão popular: “...Foi a questão da pressão/ Popular, seu desvario;/ Foi o povo e a liberdade/ Num canto de desafio."319 (grifos meus). Na sequência o cordelista insere a Inconfidência: "Sentiu D. João os anseios/ Quando no Brasil chegou, / Os cantos da liberdade/ Pelo sangue que jorrou,/ Pedaços de Tiradentes/ Do corpo que esquartejou." ${ }^{320}$ (grifos meus). Como liberdade e independência são sinônimos, então é apresentada a contestação: "Não queriam os brasileiros/ Liberdade concedida,/ Queriam como conquista/ Por sua luta aguerrida,/ Pela participação,/ Com sacrifícios de vida." ${ }^{321}$ (grifos meus). Assim, liberdade se conecta com a luta e participação popular. Por um lado insere o afastamento de uma concepção de "transição pacífica" ${ }^{322}$ pois reconhece as lutas que ocorreram no período, destacando a Inconfidência Mineira, assim como as lutas na Bahia. Por outro lado, reconhece a Independência como um acordo da Família Real, entre Brasil e Portugal.

O grito proclamado por D. Pedro: "Disfarçava um Brasil livre/ De Portugal separado.../ Igualzinho aos conformes/ Do que fora combinado." ${ }^{223}$. Portanto, a liberdade é reclamada pela luta, e a Independência é contestada. Assim, a liberdade que se conecta à luta pela Independência, ganha outro sentido do apresentado nas obras anteriores. Aqui a luta se vincula e reivindica a participação popular.

Com isso, é possível perceber como nas obras analisadas o conceito liberdade é usado de maneira abrangente ligado à defesa da Independência. Embora politizado, ganha ênfases e significados variados como os utilizados na voz dos escravizados, libertos e população pobre. Os romances sobre a revolução de Pernambuco de 1817 destacam como o vocábulo liberdade era muito utilizado como recurso retórico e conceito mobilizador

\footnotetext{
${ }^{317}$ Evaldo Cabral de MELLO. A outra independência: o federalismo pernambucano de 1817 a 1824 . São Paulo: Editora 34, 2014

${ }^{318}$ Luzimar Medeiros BRAGA, op.cit., p.11.

319 Ibidem, p.11.

${ }^{320}$ Ibidem, p.11.

${ }^{321}$ Ibidem, p.12.

${ }^{322}$ Wilma Peres COSTA, op.cit., p.56.

${ }^{323}$ Luzimar Medeiros BRAGA, op.cit., p.14.
} 
de lutas no período da Independência e da própria revolução. Mas chamam atenção sobre a liberdade conectada à questão do escravismo e como a abolição foi afastada do projeto republicano revolucionário de 1817. Embora algumas obras conectem liberdade com a Independência, a exemplo de Paraguassú (1835 e 1837), do poema Épico de Independência (1847 e 1855), e Primícias (1900), essa conexão é alterada no Cordel da história da Independência (2008), que questiona a liberdade através de uma interpretação de Independência acordada, e reivindicando a liberdade através da luta popular.

Por último, temos o conceito liberalismo e liberal, que de forma genérica, indica nas obras a adoção do regime constitucional e influência das ideias iluministas difundidas, sobretudo, com os ideais da Revolução Francesa, sempre lembrada.

Nos romances sobre a revolução de Pernambuco, liberalismo e ideias liberais se associam à maçonaria e à concepção do projeto republicano. Como já destacado, essa era uma ideia vaga, entretanto nas obras Olhos Negros (2009) e a Noiva da Revolução (2006), os termos "república" ou "projeto republicano" foram adotados de forma irrestrita. 324

Nesses romances, como salientado nos conceitos liberdade e revolução, há o destaque das discussões sobre a abolição dos escravizados no projeto autônomo. Porém, como o projeto revolucionário contava com o apoio de grandes senhores de terras da região, o ideal de abolição foi afastado. Emília Viotti elaborou uma interpretação que evidenciava que a permanência da escravidão realçava manifestações brandas e empobrecidas de ideias liberais na América portuguesa. No balanço historiográfico sobre as permanências e rupturas da Independência, abordando a elaboração de Viotti, Wilma Peres aponta:

“A aglutinação de interesses em torno da manutenção da propriedade escrava perpassa todo o campo da luta política travada durante o processo de Independência, estando presente desde as rebeliões contra o jugo colonial ocorridas no final do século XVIII, razão pela qual nem a Inconfidência Mineira, nem a Revolução Pernambucana de 1817 haviam ousado pôr em causa a instituição escravista." ${ }^{325}$

Na epopeia Primícias (1900), como já apontado, quando se aborda a Inconfidência Mineira, o autor explica no paratexto que José Alves voltara da França e Inglaterra

\footnotetext{
324 João Paulo PIMENTA, op.cit., 2003.
}

${ }^{325}$ Wilma Peres COSTA, op.cit., p.91. 
influenciado pelas ideias liberais que se espalhavam por lá ("movimento livre dos povos”) e pela Independência dos Estados Unidos ${ }^{326}$. Em longa nota ao fim do poema em que o autor explica a declaração da Independência, destaca que com a vinda da Corte para o Brasil, a fim de "abreviarem sua emancipação política, os brasileiros foram se aproveitando habilmente dos benefícios régios, e das medidas liberais do regente" ${ }^{\text {227. }}$. Tratam-se das medidas econômicas que acabaram com o exclusivo metropolitano e forneceram maior autonomia para as províncias.

Já na obra de Teixeira e Sousa, temos menção do vocábulo liberalismo em versos, e colocados de forma positiva: "— Santo Liberalismo! amor da glória."328; na sequência há um jogo de opostos, entre o termo e "despotismo":

“ - As doçuras mostrai com energia,/ Do grato, do feliz Liberalismo;/ Os horrores mostrai da tirania,/ Os horrores mostrai do Despotismo;/ Este mantém de escravos a apatia,/ Aquele gera d'homens o heroísmo;/ Este dá baque aos reis, dá vitupérios,/ Aquele dá renomes, dá impérios." ${ }^{329}$.

Nesse verso, liberalismo além de ser colocado como contrário a tirania, é o que promove progresso de governos, a projeção de futuro.

Na obra de Torero, quando o narrador escreve em seu diário sobre a convocação de uma Assembléia Constituinte por D. Pedro, o Chalaça (1994) usa o vocábulo liberal de forma irônica, sugerindo a contradição: "Eram necessárias novas leis, estáveis e serenas, para que o Brasil desse seus primeiros passos. O Imperador poderia ter outorgado uma nova Carta, mas, como prova da sinceridade do seu coração liberal, convocou uma Assembléia Constituinte." ${ }^{330}$ A construção narrativa, como característica da obra, produz o efeito imediato do humor no leitor, visto que a Assembléia foi dissolvida em 1823 e a Constituição foi outorgada pelo Imperador em 1824; o que ensejou a acusação de “despotismo" ou "tirania" de D. Pedro. E como já apontado, liberalismo se vincula á Constituinte e Constituição.

\footnotetext{
${ }^{326}$ Joaquim Gil PINHEIRO, op.cit., p. 174. O autor aponta José Alves, entretanto, acredito se tratar de José Álvares Maciel, filho do capitão-mor de Vila Rica, Ver: Kenneth MAXWELL, "Conjuração mineira: novos aspectos. Revista Estudos Avançados, v.3, n.6, 1989, p.17

${ }^{327}$ Joaquim Gil PINHEIRO, op.cit., p.221.

328 Antonio Gonsalves TEIXEIRA E SOUSA, op.cit., Tomo II, p.303.

${ }^{329}$ Momento em que o "Anjo da Verdade fala através de Clemente Pereira”. Antonio Gonsalves TEIXEIRA E SOUSA, op.cit., Tomo II, p.303.

${ }^{330}$ José Roberto TORERO, op.cit., 119.
} 
No romance de Maria Cristina Albuquerque, Olhos Negros, liberalismo é ressaltado aos que tinham acesso à difusão dos princípios liberais, ou do Iluminismo que vinham da Europa: “ O outeiro olindense, qual acrópole grega, passou a abrigar os representantes mais eruditos do clero, das ordens religiosas e da juventude estudantil. Todos estimulados pela ideias liberais que cruzavam o Atlântico. Naquele tempo, maçonaria, igreja e liberalismo político falavam a mesma linguagem.” ${ }^{331}$ (grifos meus) A maçonaria foi lembrada de forma quase natural nos livros que narram a história da Revolução de 1817 em Pernambuco, sem muitos esclarecimentos sobre o que era a maçonaria.

Em passagem de 1861 no enredo do romance, a narradora descreve: "Sua simples existência [dos padres maçons] perpetuava a lembrança de ideias libertárias, do iluminismo que transformara Pernambuco na mais brilhante das províncias brasileiras." ${ }^{332}$ (grifos meus) O novo bispo de Olinda e Recife “...tornou pública a guerra contra a maçonaria. Condenou o liberalismo que ela cultivava e propagava, infiltrada no clero e nas ordens religiosas durante meio século de lutas políticas por vezes sangrentas." 333 (grifos meus) É interessante também perceber que se passa uma impressão que a maçonaria era uma sociedade aberta, com ampla difusão do que faziam e não sociedades que embora conhecidas, tinham acesso restrito.

E assim como o romance anterior, A noiva da Revolução (2006), de Paulo Santos também associa "liberalismo" e maçonaria.

O português Luís do Rego não aceitava a ideia generalizada de que o "brasileiro é por índole liberal". Para ele (...) havia certa informalidade de costumes. Mas daí a serem liberais na sua formação moral, social e política, havia um abismo! Os princípios revolucionários artificiais e violentos, em sua opiniao, eram contrários à índole do nosso povo. (...) introduzidos por uma força exterior e desnacionalizadora; e o culpado de todas essas agitações era um indivíduo que no passado se chamava judeu, depois virou cristão-novo, em seguida liberal, e então se apelidava de republicano, tomando as cores superficiais de várias épocas. Essa figura se reunia com seus iguais numa

\footnotetext{
${ }^{331}$ Maria Cristina C. de ALBUQUERQUE, op.cit., p.22.

${ }^{332}$ Ibidem, p.21.

${ }^{333}$ Ibidem, p. 21 .
} 
grande sociedade a maçonaria, encarregada de acabar com o princípio monárquico em todo mundo. ${ }^{334}$

A narradora atribui essa concepção a Luís do Rego, percorrendo um caminho até chegar a liberal, que vira republicano e depois faz a conexão com a maçonaria, dando a impressão de uma progressão do que era considerado "inovador" ou "diferente" a partir das nomenclaturas que designam um posicionamento político. Em um primeiro momento utiliza o vocábulo como "informalidade de costumes", de forma mais próxima a uma concepção contemporânea (do autor, não da narradora, no sentido de costumes liberais), e depois a explicação sobre a formação política, e embora não mencionado, pode ser atribuída a princípios do Iluminismo.

Percorremos, dessa forma, nas obras literárias o uso de conceitos que ganharam importância no contexto revolucionário do século XIX e emergência das Independências na América. São conceitos que demonstravam o contexto politizado e de transformações profundas que faziam emergir novas palavras ou sentidos novos de palavras já existentes de maneira a tentar explicar o que se apresentava de maneira inovadora, moderna para os sujeitos daquele período. ${ }^{335}$ Aqui, encontramos muitos termos empregados pelos coevos, mesmo nas obras do século XIX, mas que já possuíam um sentido mais claro. Assim, importou entender como escritores relacionaram esses conceitos no período da Independência, no período revolucionário. Embora tenha sido percebida a conexão com o movimento das colônias da América espanhola, a ideia da Independência brasileira como uma revolução quase não foi encontrada. Os conceitos aqui apresentados já haviam sido debatidos na historiografia, a ideia de despotismo e retórica de recolonização se tornou uma maneira tradicional de interpretação da atuação das Cortes portuguesas de 1820. Embora isso já tenha sido esclarecido nos estudos historiográficos a concepção da ideia de recolonização permaneceu, e ainda vigora, como foi possível acompanhar na literatura.

Conceitos como pátria e patriotismo que tinham forte apelo retórico no século XIX, até por uma necessidade de envolvimento nas lutas na defesa da Independência do Brasil e de consolidação em torno de uma identidade e integração coletiva, nacional, foram caindo em desuso a partir do século XX. O apelo emocional vai desaparecendo nas obras. E nação ganha o sentido de designação a Estado.

\footnotetext{
${ }^{334}$ Paulo Santos de OLIVEIRA, op.cit., p.343. Os grifos foram mantidos conforme o original.

${ }^{335}$ Eric HOBSBAWM, A Era das revoluções, 1789-1848. São Paulo: Paz e Terra, 2010, p.15-24.
} 
Já o emprego do conceito liberdade ganha sentidos diversos, dependendo da causa defendida, do contexto e da voz de quem evoca. Liberdade é muito relacionada à divisão social do Brasil, e esses contornos se tornam evidentes a partir da obra de Machado de Assis, ganhando muita força a partir do século XX. Nos épicos do XIX, a liberdade se referia ao país e a defesa da Independência, ou de projetos alternativos como o Mineiro e o Pernambucano, mas há um silenciamento a respeito da questão escravista. Identificamos que o vocábulo liberdade foi ganhando conexões, qualificações, o que indica uma elaboração maior (moderna), e contornos mais claros dos sentidos da palavra. Esse aspecto de qualificação do conceito se torna mais importante quando se observa a utilização do vocábulo de acordo com a voz do grupo que representa. O mesmo se aplica ao conceito "revolução".

Embora, por exemplo, o épico Primícias (1900), utilize revolução muitas vezes com o mesmo sentido de motim, sublevação, sedição, assim como Chalaça (1994); em Viva o povo brasileiro (1984) e A noiva da Revolução (2006), o mesmo conceito apresenta sentidos diversos. Essa variação de sentidos ganha contornos maiores, também, de acordo com a voz de quem emprega a palavra, ou seja, um personagem de uma classe dominante ou do grupo dos subalternos. Dessa forma, é possível identificar que os conceitos são importantes para o período e por esse motivo foram inseridos nas obras literárias. Entretanto, com o passar do tempo foram ganhando significados distintos e variados do modo como eram utilizados no período da Independência. No caso dos vocábulos revolução e liberdade, por exemplo, ocorre uma qualificação do conceito. "Liberdade" então, passa a ser associada a justiça, igualdade, poder de escolha, etc. Com o conceito revolução ocorre o mesmo, ele passa a ser associado à dignidade, igualdade, felicidade, etc. Ou seja, o que se buscava com a revolução.

Enfim, também foi notável, sobretudo nas obras sobre a revolução de Pernambuco, A noiva da Revolução (2006) e Olhos Negros (2009), a tentativa de explicar a história com o emprego de expressões acadêmicas, muitas vezes, com o uso direto da historiografia. Torna-se muito evidente, assim, o esforço maior de ensinar a história da revolução de 1817, do que a pretensão de romanceá-la.

No capítulo seguinte serão analisadas as caracterizações e representações dos personagens da Independência. 


\section{Capítulo 2. Personagens da Independência na literatura}

Quando se trata de representações de sujeitos históricos em obras de ficção, é imprescindível lembrar que os escritores não possuem, necessariamente, compromisso com a realidade. Todavia, as referências para construção desses personagens já fazem parte de um imaginário coletivo advindo de matrizes de estudos e documentações históricas. A partir dessas noções, os autores, utilizando a imaginação, manipulam as caracterizações para que se adequem ao que planejaram para sua obra.

Sobre o assunto desse capítulo, ou seja, as representações dos personagens históricos da Independência, nos objetos aqui analisados, foram encontradas descrições com forte influência de estudos historiográficos e que já faziam parte da cultura de história do Brasil quando foram trazidas à ficção.

Algumas elaborações dos personagens apelam para traços burlescos (tanto no esboço físico quanto na apresentação de aspectos da personalidade) em narrativas cômicas, construindo caricaturas muito conhecidas em um imaginário social sobre a Independência. Outros perfis apresentam esses personagens de forma muito próxima à narrativa histórica considerada oficial, ou seja, aquela que possui tratamento na forma elevada. Contudo, é pertinente salientar que mesmo as construções cômicas e picarescas possuem matriz historiográfica. Dessa maneira, se configuram representações dos personagens da Independência que também fazem parte de uma memória coletiva e imaginário social do Brasil, tanto com tratamento elevado quanto depreciativo, entre outras abordagens dispensadas.

Os personagens de destaque das narrativas do Nordeste, aqueles que possuem relevância na história de Pernambuco e Bahia, são caracterizados a partir de uma memória histórica que os descreve enquanto sujeitos que participaram das lutas pela Independência, no caso dos pernambucanos, como revolucionários. Portanto, importam menos suas descrições físicas e mais as atuações nessas lutas e revoluções, assim como a rede de conexões que possuíam.

Assim, foi possível identificar reafirmações das representações dos personagens da Independência, sobretudo da Família Real, porém o destaque para sua importância e tipo de esquema da construção narrativa (cômico ou sério; rebaixado ou elevado), varia de acordo com o objetivo de cada obra. Nesse sentido, os épicos traçam perfis dos personagens da Família Real de maneira elevada, heróica, os exaltando. Os romances, em 
geral, apresentam caracterizações extravagantes. E as obras que narram os eventos em Pernambuco se esforçam por ressaltar a atuação dos revolucionários, sobretudo, dos centralmente envolvidos, os que lideraram a revolução de 1817 na província. Assim, são apresentados homens e mulheres que lutaram por um ideal, por uma causa.

A seguir apresento de forma mais detida as representações dos personagens nas obras literárias aqui analisadas.

\subsection{João e D. Carlota Joaquina}

Foi possível identificar que as duas linhas majoritárias de representações dos personagens da Independência na literatura seguem o que foi apresentado na pesquisa sobre a Independência e uma cultura de história no Brasil ${ }^{336}$,ou seja, uma abordagem cômica, irônica, burlesca e outra elogiosa e heroica. Contudo, encontramos também um tipo de abordagem que critica essa versão sem, no entanto, ridicularizá-la. É o caso dos romances pernambucanos que apresentam uma visão da revolução de 1817, reivindicando a preservação da memória de seus participantes e as lutas na defesa de seu projeto para a província de Pernambuco e vizinhas, de forma a resgatar essa história de uma possível marginalização ou ofuscamento.

O poema épico de Teixeira e Sousa, A Independência do Brasil (1847 e 1855), trata de forma detalhada o processo de Independência do Brasil, sempre com linguagem elevada e lisonjeira. Nesse poema os personagens são descritos de forma gradativa, ou seja, não foram escritos versos destinados a uma caracterização física dos personagens, a construção da imagem deles se dá ao longo do épico. O personagem principal é D. Pedro, o herói da epopeia, mas D. João também figura na narrativa. D. João e D. Pedro são apresentados pela forma como se relacionavam com o Brasil. Cito, inicialmente a passagem sobre D. João:

- Cinge João seu Filho a régia coroa/ João, que é pai do povo Brasileiro:/ Sábio Monarca, cuja fama voa/ Com suma glória pelo mundo

\footnotetext{
${ }^{336}$ João Paulo Garrido [et.al.], op.cit.,2014. Trata-se da pesquisa A Independência e uma cultura de história no Brasil, cujo resultado foi divulgado no artigo publicado em 2014. Nessa pesquisa foram feitas coletas de sondagem de opinião pública e análise de materiais não acadêmicos (para público não especializado) sobre a história da Independência, tais como: filmes, minisséries televisivas, romances históricos, matérias de revistas, vídeos variados do Youtube.
} 
inteiro:/ Amigo, transformou noutra Lisboa/ O seu mui caro Rio de Janeiro:/ Treze anos contente aqui passara,/ E, se fora por si, nunca o deixara. ${ }^{337}$

O poeta aponta que D. João é conhecido como sábio monarca, e a relação de afeto com o Brasil é evidenciada no verso, relação que segue ao longo do poema, demonstrando o monarca triste e insatisfeito por ter que deixar o Brasil e voltar para Portugal em 1821. Imagem que mesmo nas obras que tratam D. João de forma jocosa, permanece.

No épico Primícias (1900), de Joaquim Gil Pinheiro, são descritas poucas características dos personagens, e estes quando aparecem são apresentados de forma sutil. No verso que destaco, o narrador discorre sobre as execuções dos participantes da revolução de Pernambuco de 1817 praticadas pelo Marechal Luiz do Rego, com conhecimento de D. João após a aplicação das penas. Dessa forma, os versos que seguem demonstram uma defesa de D. João pelo poeta, que o apresenta como misericordioso:

Informado El-Rei desta crueldade/ Que em seu nome o conselho praticou,/ Para mostrar que tinha humanidade,/ Logo sua demissão lhe decretou.

Mandando-o substituir por uma alçada/ Composta de três juízes relatores;/ Lhe advertindo que fosse moderada/ Com o resto dos mais conspiradores.

Condoendo-se de alguns deles Dom João,/ (Já pelo governador favorecidos),/ Nos festejos de sua aclamação/ Perdoou aqueles menos envolvidos. ${ }^{338}$

Nos épicos, temos uma construção mais sóbria da narrativa e dos personagens, distinta do modo como são apresentados nos romances, muitas vezes através do humor, de forma satírica e pitoresca. Também é evidente que nos épicos as características físicas destes personagens não são exploradas, outro ponto dissonante do que foi encontrado nos romances, como veremos adiante.

Nos romances foi possível perceber um tipo de caracterização de D. João e Carlota Joaquina com uma construção cômica, em geral explorando a fisionomia de ambos com o intuito, sobretudo, de evidenciar aspectos marcantes e descrevê-los como feios. Além

\footnotetext{
${ }^{337}$ Antonio Gonsalves TEIXEIRA E SOUSA, op.cit, Tomo I, p.119.

338 Joaquim Gil PINHEIRO, op.cit, p.192
} 
disso, foram ressaltados os traços de personalidade de cada um, com o mesmo tipo de tratamento concedido à aparência física, de forma a construir uma caricatura de ambos.

No romance de Ruy Castro, Era no tempo do Rei (2007), prevalece o burlesco e o chiste. Dessa forma, encontramos uma reafirmação de uma abordagem tradicional dos dois personagens. Assim, nessa obra, D. João é descrito da seguinte forma: "D. João era baixo, quase gordo, com as coxas exageradamente grossas, o pescoço curto, formado por papadas em anéis, e o lábio inferior pendente, tipo beiçola". ${ }^{339}$ A descrição de Carlota Joaquina segue a mesma linha:

E Carlota, por qualquer ângulo que se a examinasse, ostentava uma feiura impenitente: era ainda mais baixa, quase anã, com uma espádua mais alta que a outra, prognata quase ao nível do desespero, tez de azeitona, buço, nariz gravado de varizes vermelhas, dentes em vários tons - escuros, amarelos, esverdeados - e ligeiramente coxa, devido a uma fratura de bacia provocada por queda de cavalo. Para lhe fazer justiça, diga-se que tinha o busto perfeito de quase todas as Bourbons... ${ }^{340}$

Evidenciam-se aqui os aspectos físicos com escárnio, de forma a desqualificar ambos os personagens. É um artifício que o narrador utiliza como se preparasse o leitor para não levá-los a sério. Se a descrição física tende a salientar supostos defeitos do casal, quando a personalidade dos dois é abordada se produz uma imagem de opostos. Em geral, no romance compensa-se a dita "feiura" de D. João com sua benevolência e simpatia, evidenciando-se então suas qualidades: "D. João exalava um tal ar de bondade, simpatia e humildade, de alguém que se comprazia em benfazer, que isso o redimia e o tornava amado." 341 Com Carlota Joaquina é o oposto: "Mas Carlota, voluntariosa, petulante e impertinente, estava além de qualquer possibilidade de redenção. Tratava mal as criadas e negrinhas, em cujas cabeças batia com o peso de seu abanico fechado. Quando irritada, atirava às paredes o que estivesse à mão..." ${ }^{342} \mathrm{E}$ mais que isso, de acordo com o narrador, a seu favor Carlota tinha o fato de "que cumprira seu papel: dera nove filhos a D. João, mesmo que os três últimos a partir de D. Miguel, não fossem dele." ${ }^{343}$ Assim, Carlota é representada como uma mulher "feia, com uma personalidade considerada desagradável,

\footnotetext{
${ }^{339}$ Ruy CASTRO, op.cit, p.82.

${ }^{340}$ Ibidem, p.83.

${ }^{341}$ Ibidem, p.83.

342 Ibidem, p.83.

343 Ibidem, p.84.
} 
ruim e infiel" e cujo único fator que a favorecia era ter "cumprido seu papel" gerando os herdeiros de D. João. Entende-se também, que além do papel de princesa, próprio de Carlota, o papel da mulher daquele período era o de procriar.

Dessa maneira, o narrador apresenta os personagens como opostos e no romance inteiro Carlota Joaquina aparece como uma conspiradora, sempre em "guerra" e pronta para derrubar D. João. Para isso utilizava artimanhas para evidenciar seus defeitos, ridicularizá-lo e desmoralizá-lo na Corte, com intuito de tirar sua credibilidade frente a outros monarcas:

Carlota nunca abandonara um de seus velhos expedientes: a calúnia subterraneamente disseminada contra a dignidade real. Carlota se aproveitava de certas fraquezas ou predileções de D. João para ampliálas e, aos olhos da Corte, fazê-lo passar por fraco, preguiçoso, apático, comilão, e pouco chegado à higiene. ${ }^{344}$

Em Era no tempo do rei (2007), como artifício para salientar o efeito cômico, Carlota subornava costureiras para apertar as roupas de D. João, e às cozinheiras para oferecerem frangos fritos dia e noite a ele, omitindo que talvez fosse mais afeito que outros monarcas aos banhos de mar, e sempre lavava as mãos após as refeições. ${ }^{345}$ Desse modo, esse romance ressalta a tipificação dos personagens de forma burlesca, no limite do cômico apelando ao ridículo, o que contribui para reafirmar uma imagem negativa sobre os monarcas do Brasil, escarnecendo-os. No caso de Carlota, as conspirações palacianas, mais conhecidas na historiografia pela atuação política da princesa ${ }^{346}$, se transformam em chiste e "picuinhas" entre os consortes. A pilhéria, inclusive, é característica própria desse romance. Assim, a relação do casal se torna material fecundo para a narrativa.

\footnotetext{
${ }^{344}$ Ruy CASTRO, op.cit., p. 139.

345 Ibidem, p. 140.

${ }^{346}$ Devido à invasão de Napoleão a Espanha, Fernando VII, rei espanhol, foi deposto e preso. Em seu lugar assumiu José Bonaparte, cujo poder não foi reconhecido pelas colônias. Como Carlota Joaquina, tinha direito ao trono na linha sucessória, tenta convencer D. João para que a apoie e consiga, dessa maneira, assumir o poder nas colônias espanholas. O intuito, com isso, seria garantir o poder num grande Império Ibérico, com a união de D. João, príncipe de Portugal e Carlota Joaquina, assumindo o poder espanhol. Embora tenha se empenhado, Carlota não conseguiu consolidar seu projeto. Esse é apenas uma exemplo, para mais detalhes sobre a atuação política de Carlota Joaquina consultar: Sara Marques PEREIRA, $D$. Carlota Joaquina - Rainha de Portugal, $2^{\mathrm{a}}$ edição ampliada. Lisboa: Livros Horizonte, 2008. E: Francisca L. Nogueira de AZEVEDO, Carlota Joaquina na Corte do Brasil. Rio de Janeiro: Civilização Brasileira, 2003.
} 
O curioso é que, ao se referir ao infante Pedro, o narrador utiliza de características supostamente herdadas da mãe, Carlota Joaquina - consideradas negativas para a personagem - para qualificá-lo: "O irônico é que foi dela, não do pai, que herdou a audácia, a coragem, a independência e o gosto pela aventura." ${ }^{347}$ Características elogiosas, o que configura um tratamento distinto ao dispensado à Carlota na maior parte da obra. O próprio narrador destaca a ironia da descrição.

Na obra de Murilo Mendes, História do Brasil $^{348}$, de 1932, encontramos dois poemas, "Embarque do papagaio real" e "A pescaria", que fornecem bons exemplos sobre uma abordagem satírica na poesia, e apresentam algumas descrições dos personagens. $\mathrm{O}$ primeiro poema, "Embarque do papagaio real", também foi analisado na tese de doutorado de Valmir de Souza ${ }^{349}$ :

Je suis pobre, pobre, pobre/ Je m'en vais d'aqui./ esse tal de Napoleão/ Vem tomar conta de minha quinta,/ Vem tomar minhas pipas de vinho,/ Vem tomar meus p'rus,/ Meus frangos, / Minhas galinhas d'Angola./ Tô fraco, tô fraco, tô fraco.

Vou-me embora, vou-me embora,/ Vou chupar laranjas,/Vou comer minhas papas, / Vou gozar no Rio de pijama.../ Se Carlota minha mulher deixar ${ }^{350}$.

O poema lembra o ritmo de uma cantiga popular, e de acordo com Valmir de Souza, D. João VI é rebaixado ao ser colocado ao nível de uma ave, o papagaio. ${ }^{351} \mathrm{O}$ efeito produzido pela repetição que dá ritmo ao poema e também lembra a cantiga, remete à voz de um papagaio reproduzindo palavras ${ }^{352}$, que simboliza a voz de D. João VI. O momento abordado é a transferência da Família Real e sua Corte para o Brasil, em virtude da invasão de Napoleão Bonaparte a Portugal, em 1807. A caracterização de D. João com menções à comida, sobretudo frangos, apresenta uma imagem já conhecida do príncipe glutão, sempre às voltas com frangos nos bolsos, bonachão, preguiçoso e pouco

\footnotetext{
${ }^{347}$ Ruy CASTRO, op.cit, p. 84.

${ }^{348}$ Murilo MENDES, op.cit., 1991.

${ }^{349}$ Valmir de SOUZA. Murilo Mendes: da história satírica à memória contemplativa. Tese de doutorado do curso de pós-graduação do Departamento de teoria Literária e Literatura Comparada da Universidade de São Paulo. São Paulo, 2006.

${ }^{350}$ Murilo MENDES, op.cit, p.37.

351 Valmir SOUZA, op.cit, p.108.

352 Ibidem, p.110. Aspecto explorado também na obra de Ruy Castro como já apresentado em trecho anterior.
} 
asseado. ${ }^{353}$ No verso "Vou gozar no Rio de pijama.../ Se Carlota minha mulher deixar", é apresentado outro tema: a relação conjugal de D. João com sua esposa Dona Carlota Joaquina, conhecida e caracterizada muitas vezes pela sua personalidade forte, e aqui retratada como "autoritária”. Segundo Oliveira Lima, D. João VI e D. Carlota Joaquina viviam num estado de "crônica desavença" 354 , e de acordo com esse autor, ela "era um dos maiores, senão o maior estorvo da vida de D. João VI", 355

Assim, essa representação e caracterização de D. João e Carlota Joaquina está presente em 1932, data da primeira versão publicada dos poemas de História do Brasil, de Murilo Mendes, e na obra de Ruy Castro, publicada em 2007. Logo, temos uma representação dos dois personagens de forma convencional e caricata. São apresentados os elementos que se referem às características físicas e personalidade de cada um através de uma vertente que aborda a história de forma cômica, picaresca, ridicularizando os sujeitos: D. João VI, "comilão", "preguiçoso" mas bondoso; e D. Carlota Joaquina, a esposa autoritária, e tida como "pouco feminina" para os costumes da época. O modo como se apresentam as descrições de D. João, primeiro sua aparência física em seguida qualidades que atenuam sua "feiúra", provocam no leitor uma simpatia pelo personagem. Sobre Carlota sobressai a sátira, a zombaria e a produção de uma imagem antipática. Entretanto, essas referências dos dois personagens foram encontradas primeiro em uma obra historiográfica. Aqui, cito passagem de Oliveira Lima:

(...) em Dona Carlota havia apenas de feminino o invólucro. A alma poderia chamar-se masculina, não tanto pelo desejo imoderado de poder e pelo cinismo quanto pela pertinácia em alcançar seus fins e pela dureza. Os filhos herdaram-lhe a vida, o excesso de vigor animal, que ela nunca conseguiu, porém, inocular no marido, pacífico e comodista. ${ }^{356}$

No poema de Murilo Mendes temos dois personagens estereotipados, mas como apresentado acima, em obra historiográfica também fica evidente esse tipo de tratamento

\footnotetext{
353 Oliveira LIMA discorre justamente sobre a construção dessa figura caricata: "São traços todos esses mais autênticos e fidedignos na sua simpática nobreza do que as anedotas picarescas que valeram a D. João VI um renome - talvez não usurpado se contido nos limites do desenho e não puxado até a caricatura - de desmazelo bonacheirão e de esperteza saloia..." Em: Manuel de Oliveira LIMA. "El Rei D. João VI". In: D. João VI no Brazil (1808-1821). Segundo Volume. Rio de Janeiro: Typ. Do Jornal do Commercio de Rodrigues \& C., 1908, p.941.

${ }^{354}$ Manuel de Oliveira LIMA. "A Rainha D. Carlota “. In: D. João VI no Brazil (1808-1821). Primeiro Volume. Rio de Janeiro: Typ. do Jornal do Commercio de Rodrigues \& C., 1908, p.265.

${ }^{355}$ Ibidem, p. 261.

${ }^{356}$ Ibidem, p.262.
} 
dispensado aos sujeitos históricos. Mais que isso, temos também presentes os movimentos da cultura de história com manifestações de ideias dos personagens da história do Brasil apresentados de forma cômica, na literatura e historiografia, e que fazem parte de um imaginário social. Assim, é possível identificar uma intertextualidade. ${ }^{357}$ As representações, dos personagens da Independência de forma caricatural, estereotipada e burlesca, com isso, são reafirmadas com o passar do tempo.

Neste ponto retomo a importância das leituras, do repertório dos leitores e da intertextualidade. Júlio Pimentel lembra que "não há autor que não seja previamente leitor e que a leitura, dentro dos limites e possibilidades do tempo e do repertório de quem a faz, constitui as bases da criação literária, põe em operação a máquina literária."358 Aqui, Pimentel se refere a criação ficcional, entretanto, o argumento se estende à história: "Também na história e em sua forma textual-narrativa, a historiografia, não há texto que não seja o cruzamento de muitas leituras. Isso, porém, não significa que não haja lugar para a capacidade criadora, para a raridade de alguma ideia ou para a potência imaginativa, seja na história, seja na ficção." 359 O que foi apresentado até este momento, é como história (e mesmo a historiografia) e literatura se contaminam. A intertextualidade foi destacada em muitos momentos e é evidente nessa dissertação. Relembrando sempre que a intertextualidade pode ocorrer de forma inconsciente, sobretudo, tratando de um tema como a Independência que os brasileiros conhecem desde muito cedo, em maior ou menor grau de entendimento e profundidade.

O interessante é que as primeiras menções ao tipo de caracterizações como as apresentadas foram encontradas em obras historiográficas. Sara Marques Pereira apresenta como se desenvolveu o que chama de "Lenda Negra" sobre D. Carlota Joaquina. A autora esclarece que os primeiros registros do perfil físico e psicológico de Carlota foram feitos por estrangeiros: o diplomata francês marquês de Bombelles, embaixador em Portugal entre 1787 e 1788, o viajante William Beckford, e a duquesa de Abrantes, Laura Junot. ${ }^{360}$ Em seguida percorre a historiografia portuguesa e brasileira demonstrando como uma imagem negativa foi se reafirmando e consolidando. No Brasil, Sara Pereira aponta o livro de D. José Presas como um importante referencial para o

\footnotetext{
357 Essa concepção de intertextualidade encontra-se em: Robert SCHOLES. "Leitura: uma atividade intertextual". In: Protocolos de leitura. Rio de Janeiro: Edições 70, 1991. p.17-64.

358 Júlio Pimentel PINTO, A leitura e seus lugares. São Paulo: Estação Liberdade, 2004, p.11-12.

${ }^{359}$ Ibidem, p.11-12.

${ }^{360}$ Sara Marques PEREIRA, "Genealogia da "Lenda Negra"”. In: D. Carlota Joaquina - Rainha de

Portugal, $2^{\mathrm{a}}$ edição ampliada. Lisboa: Livros Horizonte, 2008, p.181-216.
} 
estudo de Carlota Joaquina. ${ }^{361}$ E obra que se tornou uma referência do período joanino foi o livro de Manuel de Oliveira Lima, D. João VI no Brasil, publicado no primeiro centenário da vinda da Família Real para o Brasil, em 1908. Embora seja uma obra séria, de vasta pesquisa, o modo como o autor descreve o casal e aborda a relação matrimonial dos consortes, fez com que as descrições fossem facilmente transformadas em cômicas, utilizadas para o humor. ${ }^{362}$

Nas obras literárias, os dois personagens são descritos unidos, e dificilmente nesses romances encontramos apenas a citação de um deles. Normalmente se constrói um jogo de opostos entre D. João e D. Carlota Joaquina, não apenas para abordar sobre o matrimônio de ambos mas para reforçar as intrigas, os adultérios, e as diferenças entre o casal, sendo Carlota sempre detratada.

Em Olhos Negros (2009), mesmo em citação breve sobre Carlota Joaquina, encontramos a reafirmação da mesma imagem pejorativa. É assim que a narradora, Maricotinha, se refere à monarca: "A independência do Brasil fora declarada por Pedro I. Um príncipe filho de Carlota Joaquina, mulher desagradável e absolutista..."363

Na obra de Paulo Santos, A Noiva da Revolução (2006), há uma passagem em que a narradora, Maria Teodora, discorre sobre o casal, inclusive sobre a relação entre ambos e sem nenhuma novidade, o que se vê é a reafirmação dos estereótipos tais quais apresentados até aqui. A narradora descreve primeiro D. João:

Sua Alteza o Príncipe Regente, senhor de Portugal, Brasil e Algarves, Duque de Bragança, Barcelos e Guimarães, Marquês de Viçosa e Conde de Arraiolos, era baixo, gordo, comilão, carola e famoso por não ter pressa para nada. Ele sempre deixava as coisas amadurecerem até quase a podridão, antes

\footnotetext{
${ }^{361}$ Ibidem, p.186-187. O livro citado é: D. José PRESAS, Memórias Secretas de D. Carlota Joaquina, tradução revista, anotada e prefaciada por R. MAGALHÃES JR. Rio de Janeiro: Irmão Pongetti e Zélio Valverde Editores, 1940. A primeira edição foi publicada em Bourdeaux em 1830. Em resenha sobre o livro é indicado que foi publicada outra edição em 1858. Em: J. WITTER (1969). "Presas, D. José Memórias de D. Carlota Joaquina". Revista Do Instituto De Estudos Brasileiros, (6), 149-150.

${ }^{362}$ Sobre a escrita de Oliveira Lima consultar: Ricardo Souza de CARVALHO, "Oliveira Lima entre a história e a literatura". In: Belle Époque: crítica, arte e cultura. Rio de Janeiro: LABELLE, São Paulo: Intermeios:Fapesp, 2016, p.85-101. Em disciplina cursada na pós-graduação "Literatura, História e Nação na passagem dos séculos XIX-XX: Joaquim Nabuco, Euclides da Cunha e Oliveira Lima", o professor Ricardo Carvalho também debateu a questão em aula e apontou que Oliveira Lima utiliza recursos literários na construção de seu livro, embora queira seguir critérios de pesquisa apoiados em fontes. Assim, Ricardo Carvalho, indica que o modelo empregado para convencimento da parte do leitor é próximo do romanesco. Sobre Oliveira Lima consultar também: Teresa MALATIAN, Oliveira Lima e a construção da nacionalidade. São Paulo: Fapesp, Bauru: EDUSC, 2001.

${ }^{363}$ Maria Cristina C. de ALBUQUERQUE, op.cit., p.329.
} 
de se decidir por uma delas. ${ }^{364}$

E na sequência, vêm a atenuação das críticas: "Porém, o que todos pensavam ser apenas moleza e indecisão, era também cautela e esperteza, me disse certa vez o padre Ribeiro." ${ }^{365}$ E mesmo que não fosse necessária a descrição de Carlota Joaquina, pois o que a narradora descreve em seguida é a atuação política de D. João e a relação com a Corte e a distribuição de cargos, Carlota é citada. A menção segue o estereótipo traçado por Oliveira Lima e encontrado também na obra de Ruy Castro como apresentado anteriormente. Assim, a narradora de A noiva da Revolução (2006) cita a aparência de Carlota de forma pejorativa, especula sobre o suposto adultério e sobre a personalidade da princesa:

No meu entender, Dom João...possuía uma paciência monumental. Senão, como ele aguentaria sua mulher, dona Carlota Joaquina, dez anos mais moça e mãe de nove filhos, vários dos quais não eram dele? Além de ser uma fera, conforme me disseram, essa princesa de Espanha era baixinha, feia, disforme e vivia infernizando-o para voltar à Europa. Afora ter barba e bigode. ${ }^{366}$

Dessa forma, embora a ênfase na descrição dos personagens recaia sobre os participantes da revolução Pernambuco de 1817, quando há menções à Família Real ficam evidentes as reafirmações de clichês e estereótipos que se repetem nas obras. São perfis construídos nos séculos XVIII e XIX que se consolidaram e se reafirmam atravessando séculos.

Considerando que são personagens estudados no ensino básico e que possuem pesquisas na historiografia, que também são parte da memória coletiva e compõem um imaginário social e uma cultura de história, fica clara também a intertextualidade dessas obras. Devido a esses fatores, como indicado anteriormente, essa intertextualidade pode ser inconsciente por parte dos escritores. As descrições dos monarcas utilizam os mesmos adjetivos e tipificações, elaborando assim uma composição tradicional. São representações muito semelhantes: exploram certos aspectos da personalidade de ambos; o caráter da vida privada e especulações sobre o matrimônio de D. João e D. Carlota Joaquina ou as relações extraconjugais, principalmente de Carlota. É interessante

\footnotetext{
${ }^{364}$ Paulo Santos de OLIVEIRA, op.cit., p.190.

${ }^{365}$ Ibidem, p. 190.

${ }^{366}$ Ibidem, p. 191.
} 
observar inclusive, no caso de D. João, a utilização de um movimento padrão para descrevê-lo primeiro de forma pejorativa e cômica, e na sequência é apontada alguma ou um conjunto de qualidades que atenuem a impressão negativa.

A pesquisadora Francisca Azevedo fez vasto estudo sobre Carlota Joaquina ${ }^{367}$, e lembra que o perfil descrito por Manuel de Oliveira Lima, em sua obra D. João VI no Brasil $^{368}$, publicado em 1908, e que possui um capítulo dedicado à personagem, virou referência para outras obras historiográficas, livros didáticos, filmes, minisséries televisivas, compondo um senso comum que permanece através dos séculos. A pesquisa de Oliveira Lima foi baseada nas descrições encontradas nos registros de Laura Junot, a duquesa de Abrantes, que acompanhou seu marido o general Jean-Andoche Junot durante a ocupação francesa à Península Ibérica ${ }^{369}$. De acordo com Francisca Azevedo, tais registros marcam um olhar de superioridade francesa, destacando o que era considerado exótico e atrasado na Península ${ }^{370}$ E ressalta que tanto a historiografia brasileira como a portuguesa construíram uma imagem parcial e implacável de Carlota Joaquina, compondo um imaginário social que a descreve como uma "mulher vulgar, ambiciosa, perversa, inculta, enfim, transgressora de todas as normas morais e éticas inerentes às mulheres da nobreza de seu tempo". ${ }^{371}$ Atualmente temos trabalhos como os de Marcela Ternavasio $^{372}$, de Francisca de Azevedo ${ }^{373}$ e de Sara Marques Pereira que traçam como o perfil negativo de Carlota Joaquina foi se desenvolvendo na historiografia portuguesa e brasileira. Mas o retrato apresentado por Oliveira Lima, baseado nos relatos de Laura Junot, se tornou consagrado sem sofrer alterações com o passar do tempo. O mesmo vale para o caso de D. João, cuja obra é referência para o período. Vide as representações

\footnotetext{
${ }^{367}$ Francisca L. Nogueira de AZEVEDO, Carlota Joaquina na corte do Brasil. Rio de Janeiro: civilização Brasileira, 2003. A pesquisadora se debruçou num conjunto de 1453 documentos, entre cartas privadas, ativas e passivas, relatórios, manifestos e material de propaganda política que se refere à Carlota Joaquina, para traçar sua biografia e perfil.

${ }^{368}$ Manuel de Oliveira LIMA. "Rainha Carlota"..., op.cit., 1908. A influência da obra de Oliveira Lima na descrição e caracterização de D. João e Carlota Joaquina e permanece até hoje, é evidente.

$369 \mathrm{O}$ general Jean-Adoche Junot comandou a invasão das tropas de Napoleão Bonaparte à Portugal em novembro de 1807. Ocorreram ainda mais duas invasões, em março de 1809, liderada por Nicolas Jean de Dieu Soult, e em agosto de 1810, sob comando de André Massena. Em: Lúcia Maria Bastos P. NEVES, "Portugal durante a ausência do rei". In: Revista USP, São Paulo, n.79, p.10-21, setembro/novembro, 2008. ${ }^{370}$ Francisca L. Nogueira de AZEVEDO, op.cit, p.20.

${ }^{371}$ Ibidem, p.15.

372 Marcela TERNAVASIO, Candidata a la corona. La infanta Carlota Joaquina en el laberinto de las revoluciones hispanoamericanas. Buenos Aires: Siglo XXI, 2015.

${ }^{373}$ Além do trabalho de Francisca L. Nogueira de AZEVEDO, Carlota Joaquina ... op.cit, 2003. Ver: Sara Marques PEREIRA. D. Carlota Joaquina e os "Espelhos de Clio": actuação política e figurações historiográficas. Lisboa: Livros Horizonte, 1999.
} 
encontradas em obras literárias mais recentes como a de Ruy Castro, publicada em 2007, por exemplo.

\subsection{Pedro}

D. Pedro ${ }^{374}$ recebe três tipos de tratamento: o de herói da Independência, onde se destaca sua atuação política; o autoritário ou tirano, devido o fechamento da Assembléia Legislativa e outorga da Constituição em 1824; e cômico, que ressalta dados de sua vida privada, como casos extraconjugais, a epilepsia, a boemia e o episódio sem nenhuma relevância para o processo de Independência do Brasil: seu suposto mal-estar no riacho do Ipiranga.

Em Paraguassú (1835 e 1837), D. Pedro aparece como o "Grande Fundador do Pátrio Império e Príncipe Magnânimo"375, "paládio da União Brasília”376. Não há um destaque do monarca e nem a diminuição de seu papel, porém, o foco central dessa epopeia é a guerra da Independência nas batalhas travadas na Bahia. O elogio e a construção do poema são concedidos às batalhas e aos que ali lutaram. Ladislau dos Santos Titara dedicou a epopeia Paraguassú ao Visconde de Pirajá, fugindo a um "protocolo" de muitas obras do período em dedicar ao Imperador. Ainda assim, o tratamento dispensado a D. Pedro é elevado. O personagem não perde a designação como defensor e fundador do Império brasileiro.

Se nas epopeias do século XIX temos composições elevadas do personagem, outras obras, a partir do século XX, apresentam D. Pedro de forma cômica, de maneira a desconstruir a projeção de "nobre herói".

Na Epopeia da Independência de Teixeira e Sousa (1847 - 1855), o poeta constrói a imagem de D. Pedro como o protagonista do poema. Ele é o herói que enfrenta desafios e tribulações de forma nobre, o responsável por livrar o Brasil e os brasileiros ${ }^{377}$ do "jugo

\footnotetext{
${ }^{374}$ Para uma biografia do personagem ver: Octávio Tarquínio de SOUSA, Vida de D. Pedro I, 3 vol. Belo Horizonte: Itatiaia, 1988; Isabel LUSTOSA, D. Pedro I: um herói sem nenhum caráter. Elio GASPARI \& Lilia M. SCHWARCZ (coord.). São Paulo: Companhia das Letras, 2006; e Paulo REZUTTI, D. Pedro: $a$ história não contada. São Paulo: Leya, 2015.

${ }^{375}$ Ladislau dos Santos TITARA, op.cit., p.292.

${ }^{376}$ Ibidem, p.535.

${ }^{377} \mathrm{O}$ tema sobre identidades políticas no Brasil será tratado no capítulo 3.
} 
despótico de Portugal" ${ }^{378}$. Essa imagem do herói e sua relação com o Brasil é trabalhada ao longo de toda obra, mas destaco alguns trechos:

Os fados rege da Brasília terra/ O do Sexto João filho famoso/ P'ra quem a urna do Destino encerra/ Amplo de glórias um porvir grandioso!/ Nascido para ser grande na guerra/ E o povo do Brasil tomar ditoso;/ Era Mancebo destemido, e ardente/ De uma série de Heróis grão descendente! ${ }^{379}$

Em outro verso segue a descrição do predestinado e amado herói: “...Era dos Brasileiros mui bem quisto/ E deles todos em geral amado!/ Com ânimo de Herói tinha previsto/ O quanto o céu lhe havia reservado;/ Que seria, segundo a Providência/ Herói da Brasileira Independência." ${ }^{380}$ Adiante no poema completa que o jovem destinado, pensando no bem do futuro Estado: "Prudente, prevenido, e acautelado,/ A bem do povo sábias leis promulga;/ A tudo acode cheio de energia,/ Anima a paz, impostos alivia;’381.

Como é possível verificar temos o príncipe destemido, responsável, cauteloso e prudente, descendente de uma linhagem de heróis e destinado a promover a Independência do Brasil. Essa configuração do herói libertador é muito colada à construção da memória referida como oficial da Independência, tal qual o herói pintado por Pedro Américo na obra "Independência ou Morte!" 382 . Ressalto, que a epopeia foi publicada em meados do século XIX, momento em que se trabalhava na consolidação de uma identidade e memória nacional. Essa obra de Teixeira e Sousa transparece um aspecto instrutivo, para ensinar a história dessa maneira.

\footnotetext{
${ }^{378}$ Essa é uma interpretação do poeta na obra, que apresenta a ideia de que Portugal queria "recolonizar" o Brasil, como apresentado no capítulo 1. A designação "brasileiros" no período é do poeta também. Sobre o tema ver: Antônio Rocha PENALVES. A recolonização do Brasil pelas Cortes: história de uma invenção historiográfica. São Paulo: UNESP, 2009.

${ }^{379}$ Antonio Gonsalves TEIXEIRA E SOUSA, op.cit., Tomo I, p.16.

380 Ibidem, p. 17

${ }^{381}$ Ibidem, p. 147.

382 Pedro Américo de Figueiredo e Mello foi artista ativo na composição de obras históricas, dentre elas cito além do já referido quadro Independência ou Morte!, produzido entre 1886 e 1888; A Batalha de Avahy, de 1877 e Tiradentes Esquartejado de 1893. Jorge Coli, historiador da Arte analisou algumas destas obras. Em Tiradentes Esquartejado, Coli afirma que Pedro Américo "emprega a ciência do anatomista e a ciência do historiador", pois se elabora a pintura do corpo esquartejado, a composição como um todo une heroísmo, história e imagem artística para compor o mito. Em: Jorge COLI. "Os poderes dos fragmentos". In: O corpo da liberdade: reflexões sobre a pintura do século XIX. São Paulo: Cosac Naify, 2010, p.311. Em A Batalha de Avahy, Coli percebe que Pedro Américo, que era Doutor em Filosofia, escritor de romances e debatedor religioso, demonstra suas razões como artista: "consciência que ele possui do seu papel nas artes brasileiras, consciência de seus vínculos com uma História imediata na qual o pintor se concebe como um historiador visual...". Em: Jorge COLI,"O sentido da batalha: Avahy, de Pedro Américo".In: Projeto História. Revista do Programa de Estudos Pós-Graduados de História, v. 24, ago. 2012.
} 
O poema "A pescaria”, do livro História do Brasil (1932), de Murilo Mendes, trata D. Pedro e o "Grito de Independência" na forma de sátira:

Foi nas margens do Ipiranga,/ Em meio a uma pescaria./ Sentindo-se mal, D. Pedro/ - Comera demais cuscuz -/ desaperta a barriguilha/ E grita, roxo de raiva:/ "Ou me livro d'esta cólica/ Ou morro logo d'ua vez!"/ O príncipe se aliviou,/ Sai no caminho cantando:/ "Já me sinto independente,/ Safa! Vi perto a morte!/ Vamos cair no fadinho/ Pra celebrar o sucesso,"/ A Tuna de Coimbra surge/ Com as guitarras afiadas,/ Mas as mulatas dengosas/ Do Club Flor do Abacate/ Entram, firmes, no maxixe,/ Abafam o fado com a voz,/ Levantam, sorrindo, as pernas.../ E a colônia brasileira/ Toma a direção da farra ${ }^{383}$.

Um incidente lembrado no poema e explorado em outras abordagens humorísticas e satíricas foi a disenteria do príncipe regente D. Pedro às margens do riacho do Ipiranga. No poema as referências que lembram a passagem do "grito do Ipiranga", ressaltam o episódio que foge a uma narrativa épica, heroica, porém que faz parte da memória oficial. O trocadilho se dá pela inversão: D. Pedro se torna independente (livre) da cólica e do mal-estar, indicados nos versos "Ou me livro desta cólica/ Ou morro logo d'ua vez!" 384 . São referências ao episódio histórico, e pode se tratar também de uma metáfora (o malestar e a morte) sobre as relações entre Brasil e Portugal, entretanto, como este é um poema satírico o intuito maior é tornar evidente o ridículo e o cômico. O trocadilho ocorre porque o famoso grito do Ipiranga: “Independência ou Morte!” vira "Já me sinto

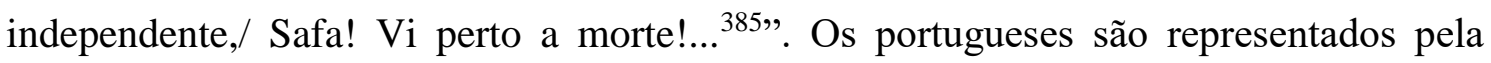
“Tuna de Coimbra” e o Brasil pelas "mulatas dengosas que entram firmes no maxixe, abafando o fado com a voz e levantam sorrindo as pernas"386, aqui há uma alusão à miscigenação, pelas mulatas com os portugueses, sobretudo pelo verso "Levantam, sorrindo, as pernas..." 387 Tratam-se, ademais, de indicações de referências da cultura e estereótipos de Brasil e Portugal. Dentro das concepções do Modernismo ressaltando a cultura brasileira é possível estender a análise. Há a oposição no contexto cultural do fado,

\footnotetext{
${ }^{383}$ Murilo MENDES, op.cit, p.46.

${ }^{384}$ Ibidem, p.46.

385 Ibidem, p.46.

${ }^{386}$ Ibidem, p.46. "Fado" nesse poema, se refere a um tipo de música popular portuguesa. Nos épicos "Fado" têm sentido de destino ou profecia.

${ }^{387}$ Murilo MENDES, op.cit, p.46.
} 
gênero típico de Portugal e o maxixe, gênero típico do Brasil. ${ }^{388}$ José Miguel Wisnik esclarece que o maxixe era gênero ligado aos ambiente populares

inseparáveis dos contingentes de escravos e das músicas tocadas e dançadas por negros, e propagado inicialmente nos ambientes boêmios contíguos à vida noturna, ao teatro de revista e à prostituição - frequentados por homens - o maxixe, cujo nome associa-se originariamente ao legume barato, ao resto e ao lixo, é contaminado de uma sanção moral, para efeitos do decoro familiar. ${ }^{389}$

O que se configura nos versos do poema é a adoção do "fadinho" por D. Pedro para celebrar o sucesso, sendo abafado pelo maxixe. É a cultura brasileira se sobrepondo ou "vencendo" a portuguesa. A partir do maxixe se aponta na direção da farra: trata-se de mais um estereótipo do Brasil, o país festeiro, o país do carnaval (entrudo na época), da bagunça. Sem esquecer a referência da miscigenação a partir da presença das mulatas. Tomando a origem do maxixe, como explicado por Wisnik, há um reforço indireto ao caráter boêmio de D. Pedro. Enfim, nos dois versos finais do poema a indicação da direção assumida pode sugerir analogamente à Independência do Brasil. No poema é utilizada a expressão "colônia brasileira", porém o Brasil havia sido elevado a Reino, unido a Algarves e Portugal em 1815. Portanto, a referência à colônia poderia indicar uma concepção do Brasil, com a presença de D. Pedro, continuando como uma colônia. Essa é uma leitura possível.

Assim, no poema que trata da história através do humor são encontrados alguns clichês que também fazem parte do imaginário e cultura do Brasil, conforme a análise apresentada. Além disso, corresponde aos pressupostos do Modernismo, ou seja, a busca

\footnotetext{
${ }^{388} \mathrm{O}$ maxixe se popularizou na realidade no final do século XIX e começo do XX, mais especificamente a partir de 1870. Se originou no Rio de Janeiro, inicialmente era considerado uma dança e progressivamente passou a ser considerado um gênero musical. Em: Carla Crevelanti MARCÍLIO, Chiquinha Gonzaga e o Maxixe. Dissertação de mestrado apresentada ao Programa de Pós-Graduação em Música, do Instituto de Artes da Universidade Estadual Paulista "Júlio de Mesquita FilholUNESP. São Paulo, 2009, p.48- 50.

389 José Miguel WISNIK, "Machado maxixe: o caso Pestana". In: Teresa, n.4-5, p.13-79, 2003, p., 26. Wisnik aponta ainda que o gênero era difundido oral e teatralmente, mas permanece impublicável até 1987, data da primeira partitura impressa sob esse nome. A partir da primeira década do século XX passou a ser reconhecido e adotado publicamente. Ibidem, p.26. Wisnick indica: José Ramos TINHORÃO, "O maxixe". In: Pequena história da música popular brasileira (da modinha à canção de protesto), $3^{\mathrm{a}}$ ed. Petrópolis: Vozes, 1978, p.51-83. Ver também: Jota EFEGÊ, Maxixe - A dança excomungada. Rio de Janeiro: Conquista, 1974; Aquilino José de BRITO, "Maxixe: Dança e Música na Circularidade Cultural Brasileira". XXVII Simpósio Nacional de História $\backslash$ ANPUH: Conhecimento histórico e diálogo social. Natal- RN, 22 a 26 de julho de 2013.
} 
de uma renovação estética e de uma expressão artística nacional, com uso do humor e linguagem popular, resultando num afastamento de uma modelo academicista. ${ }^{390} \mathrm{~A}$ passagem que se evidencia é o conhecido mal-estar de D. Pedro e através desse episódio o poeta constrói essa representação com elementos que remetem ao Brasil e cultura brasileiras e elementos que remetem a Portugal sem, entretanto, discorrer de forma direta sobre o episódio da Independência. A memória e a história nessa abordagem humorística são subvertidas, causam estranhamento ao leitor. De acordo com Elias Thomé Saliba, no seu ensaio sobre as possibilidades cognitivas do humor em Pirandello: "tudo aquilo que nos é familiar é colocado num contexto desconhecido ou estranho, o senso comum é rompido, o inesperado é evocado - e o humor se transforma numa estratégia de desfamiliarização." 391

Murilo Mendes soube manipular a linguagem e o humor nas representações de episódios da história do Brasil e da Independência. Através da sátira, ressaltou dados que embora mesclados com a ficção, fazem o leitor perceber a que se refere, sem citar explicitamente os eventos da história. Além disso, como no poema sobre a transferência da Corte "Embarque do papagaio real", analisado anteriormente, ocorre o rebaixamento de D. Pedro do mesmo modo como se procedeu à D. João e Carlota Joaquina.

Em Era no Tempo do rei (2007), o narrador demonstra de maneira irônica algumas ideias sobre a imagem que o infante Pedro viria a ter: "Ninguém via nele o futuro imperador, o libertador do Brasil, o monarca despótico e querido. Nem mesmo o monstro sedutor, sóbrio e luxurioso, que faria a infelicidade de sua imperatriz e distribuiria gozo e deleite entre marquesas e plebeias." ${ }^{392}$ Aqui estão resumidas as várias facetas que definem representações de D. Pedro: a figura política e herói que libertou o Brasil, que depois se mostrou despótico quando fechou a Constituinte e outorgou sua Constituição. E também o sedutor príncipe, rodeado de rumores de casos extraconjugais. Assim, parece que o próprio narrador conhece essa tripla imagem de D. Pedro e as maneja muito bem em seu romance.

Em outra passagem, numa festa de rua, Pedro e Leonardo resolveram trocar de roupas entre si: "Ninguém tomou Leonardo por príncipe. Mas Pedro estava a caráter,

\footnotetext{
390 João Luiz LAFETÁ, “Os pressupostos básicos”. In: 1930: a crítica e o modernismo. São Paulo: Duas Cidades, 1974, p.11-27.

${ }^{391}$ Citação de Pirandello em: Elias Thomé SALIBA. Raízes do riso. A representação humorística na história brasileira: da Belle Époque aos primeiros tempos do rádio. São Paulo: Companhia das Letras, 2001, p.25-26.

${ }^{392}$ Ruy CASTRO, op.cit, p.242.
} 
como estaria pela vida afora, em seu papel de azougue, xucro e irresistível, grosso e fino, puro e depravado, que nem o Brasil." 393 Nesse trecho, as descrições atribuídas ao personagem também se referem ao Brasil e reforçam as concepções anteriores.

Em Chalaça (1994), temos também a descrição da cena do Ipiranga e menções ao caso de D. Pedro com Domitila de Castro. Na descrição do grito da Independência pelo narrador, Chalaça explica que havia sido convidado a participar da viagem à São Paulo porque era companheiro de boemia de D. Pedro. A viagem foi feita para tentar apaziguar uma sedição na província. D. Pedro e comitiva foram recebidos festivamente pelos habitantes de São Paulo e os insurgentes foram enviados para o Rio de Janeiro. A comitiva seguiu viagem rumo a Santos. Nesse trecho, o narrador explora longamente e de forma irônica o fato da comitiva e D. Pedro sofrerem um mal-estar durante a viagem. Com isso, novamente se apresenta o episódio de D. Pedro com "dor de barriga", às margens do riacho Ipiranga, momento em que declara a Independência. Nos planos de construção da narrativa, na voz do próprio Chalaça, a maior ironia é essa:

"Não querendo ficar ali - para não ser motivo de pilhéria por parte da gente do lugar -, D. Pedro determinou que subíssemos a serra imediatamente. Antes, porém, de termos alcançado o povoado de Cubatão, muitos de nós éramos obrigados a frear os animais e apear para a necessária evacuação."394

A ironia se dá porque criou-se uma imagem, uma representação desse fato que é amplamente lembrado e explorado culturalmente, sobretudo por aqueles que abordam a história da Independência através do humor, de forma a desqualificá-la. E se no romance D. Pedro não queria permanecer na província para não ser motivo de pilhéria pelo malestar, certamente o foi para a história. Dessa maneira, a narrativa continua apresentando a versão mais tradicional de uma memória oficial da Independência. No romance o Chalaça funciona como testemunha dos eventos junto a D. Pedro, e narra a história de forma cômica e irônica, a partir de seu ponto de vista. ${ }^{395}$

\footnotetext{
${ }^{393}$ Ibidem, p.243.

394 José Roberto TORERO, op.cit, p.107.

395 Stanis David LACOWICZ, aproxima a obra Chalaça de Roberto Torero na tradição da picaresca espanhola, mas esclarece que ela é bem definida cronologicamente (século XVI e XVII), por isso relaciona por aproximação Chalaça ao gênero. O romance picaresco surgiu na Espanha do século XVI a partir da obra Lazarillo de Tormes, de autor anônimo. O gênero se consolidou com os textos Guzmán de Alfarrache, de Mateo Alemán, e História de la vida del Buscón, de Quevedo. Essas obras, de acordo com o autor, estabeleceram as características do picaresco clássico, e menciona a definição de Mário González: "a presença do anti-herói pícaro; seu projeto de ascensão social pela trapaça; a sátira social exposta ao longo
} 
A dissolução da Assembleia Constituinte, é explicada por uma tentativa de fazer o "Príncipe D. Pedro" (ele volta a ser príncipe) um "soberano decorativo."396 Após a dissolução da Assembleia e má repercussão nas ruas, D. Pedro manda escrever nova constituição: "Para dar provas, no entanto, de que ninguém mais do que ele detestava a tirania, D. Pedro mandou-me imediatamente trabalhar numa nova Carta constitucional para ser outorgada à nação brasileira." ${ }^{397}$ Além da figura do sedutor, herói e libertador da nação, temos também o tirano. Assim, é possível perceber que apesar do chiste no discurso, a representação tanto da Independência, quanto dos personagens é fortemente tradicional, a partir da memória oficial a obra constitui uma abordagem cômica também muito habitual dos personagens, como é possível verificar.

Após a dissolução da Constituinte, o conselheiro Gomes foi encarregado de escrever nova constituição. Assim que acaba de redigir apresenta à D. Pedro que se encontrava na casa da amante, Domitila de Castro. Dessa maneira, a faceta de D. Pedro, como sedutor amante e infiel ao matrimônio também é apresentada.

Em obra mais recente de 2008, o Cordel da história da Independência de Luzimar Medeiros Braga, há uma ênfase no processo político, entretanto, foi possível encontrar uma breve caracterização de D. Pedro e mais uma referência ao episódio do mal-estar que sofreu às margens do riacho do Ipiranga:

Mas, D. João VI acuado, / Por Portugal, sua gente,/ Tirou de D. Pedro I/O seu título de regente,/Levando assim mais motivo/De fazê-lo independente.

Epilético, muitas vezes/Não se mantinha de pé,/E fazia extravagâncias/Com bebida e com mulher/Que chegava a desarranjos/ Parecendo um pangaré.

E certa vez cavalgando/ Manifestou de verdade/ Forte dor estomacal/ Que abatendo a vaidade/ Teve que satisfazer-se/ Na sua necessidade. ${ }^{398}$

\footnotetext{
desse processo e o relato autobiográfico de um indivíduo às margens da sociedade e que não teria quem narrasse sua história, além dele mesmo." Lacowicz, lembra inclusive que Lazarillo de Tormes é leitura do personagem no livro de Roberto Torero. Em: Stanis David LACOWICZ, Mitos Hispânicos no romance histórico brasileiro: uma leitura de O Chalaça (1994) e de O feitiço da ilha do Pavão (1997). Dissertação de Mestrado apresentada à Faculdade de Ciências e Letras da Universidade Estadual PaulistalUNESP. Assis, 2012, p.9-26.

${ }^{396}$ José Roberto TORERO, op.cit., p.120.

${ }^{397}$ Ibidem, p. 120.

${ }^{398}$ Luzimar Medeiros BRAGA, op.cit, p.13-14.
} 
Nestes versos o poeta descreve D. Pedro como "mulherengo e boêmio", imagem que faz parte de uma representação comum do personagem, e destaca sua doença: sofria de epilepsia. A escolha em evidenciar essas características, sua doença, e o episódio do malestar na viagem à São Paulo o distanciam da imagem construída do "nobre/elevado herói" da Independência, rebaixam o príncipe ao plano mundano.

Este cordel possui uma abordagem crítica da Independência mas, ainda assim, distingue-se nos versos, mesmo que em uma breve passagem, o estereótipo de D. Pedro afeito a casos extraconjugais e boêmio. Fatores que normalmente são explorados para satisfazer curiosidades de leitores sobre a vida privada dos monarcas brasileiros, e para rebaixar a imagem de suposto herói da nação como versa uma narrativa dita oficial da Independência.

Portanto, D. Pedro, assim como D. João e D. Carlota Joaquina, possui representações já consagradas. Ocorrem, dessa forma, reafirmações de clichês, estereótipos, caricaturas que exploram o papel de D. Pedro como estadista, ora de maneira elevada como o herói responsável pela Independência do Brasil, ora como tirano, devido o fechamento da Constituinte e outorga da carta constitucional em 1824. A vida privada do personagem também é sempre ressaltada, realçando a boemia de $\mathrm{D}$. Pedro, além dos casos extraconjugais que manteve, sobretudo com Domitila de Castro, e a doença que tinha, a epilepsia. Na literatura, portanto, essas imagens muito tradicionais continuam sendo reiteradas.

\subsection{Personagens femininas: Imperatriz Leopoldina, D. Amélia e Domitila de Castro}

Se Carlota Joaquina foi representada como uma mulher "à frente de seu tempo" por seu temperamento e atitudes (tidos como supostamente masculinos e não adequados a uma mulher, pensando nos valores do século XIX), tendo sua relação com D. João muito explorada na construção de sua imagem, e sua aparência sempre retratada de forma pejorativa, temos em Leopoldina ${ }^{399}$ o oposto. Sua imagem é tomada como "ideal" para uma mulher e uma soberana do século XIX. Embora Leopoldina seja citada, sua imagem é explorada em uma proporção muito menor que Carlota Joaquina. Se um dos pontos

${ }^{399}$ Carlos H. OBERACKER JR., A Imperatriz Leopoldina: sua vida e sua época: ensaio de uma biografia. Rio de Janeiro: Conselho Federal de Cultura, 1973. Luiz NORTON, A corte de Portugal no Brasil: notas, alguns documentos diplomáticos e cartas da Imperatriz Leopoldina. Coleção Brasiliana. São Paulo: Companhia Editora Nacional, 1938. 
destacados de D. Pedro são seus casos extraconjugais, em Leopoldina é destacada sua resiliência. Normalmente os adjetivos que a acompanham destacam suas virtudes.

Teixeira e Sousa, na epopeia da Independência do Brasil (1847 e 1855), apresenta D. Leopoldina da seguinte forma:

É a Princesa amável, instruída,/A Deus muito temente, e mui piedosa,/ Discreta, de candura, revestida,/ Nobre em suas ações, assaz virtuosa;/ Dos males, das desgraças condoída,/ E para com os pobres caridosa:/ Veio com gênio assim tão nobre, e santo,/ Ser o bem do Brasil, do esposo o encanto! ${ }^{400}$

Seguindo a descrição elevada, Teixeira e Sousa destaca sobretudo as qualidades de Leopoldina, a distinção de suas ações, sua boa personalidade e sua benevolência. Mesmo na obra que virá na sequência e que faz uso do humor, o tipo de tratamento dedicado a Leopoldina é o mesmo.

Na obra de Torero, Chalaça, (1994), além de Leopoldina (citada de forma superficial, muito brevemente), as figuras femininas que se destacam são: a amante de D. Pedro, Domitila de Castro Canto e Melo, e a segunda esposa de D. Pedro, D. Amélia de Leutchtenberg, que no final da trama se casa com o Chalaça. De modo geral, a narrativa destaca aspectos físicos ressaltando ora beleza, voluptuosidade e sensualidade das personagens; ora defeitos, também relativos à aparência.

Sobre Leopoldina, embora seja destacada sua erudição, "A erudição de D. Leopoldina o intimidava [a D. Pedro]..."401, também é realçada sua suposta tranquilidade: “(...) chegasse a nossos ouvidos a mui lamentável notícia do falecimento da esposa do senhor D. Pedro, a sereníssima - poucas mulheres fizeram tanta justiça a esse nome senhora Imperatriz D. Leopoldina". ${ }^{402}$

Sobre Domitila, destacam-se as características físicas e seu caso duradouro com D. Pedro. Assim Domitila é descrita: "Devo dizer, em sua honra, que era mulher ondulada, formosa, de olhos vivos e partes muito rijas e bem servidas"403

Quanto a D. Amélia, aparece na trama como a responsável pela expulsão do Chalaça do Brasil. Porém, quando este a reencontra em Portugal, por ocasião da guerra de sucessão do trono português, imperam as descrições físicas:

\footnotetext{
${ }^{400}$ Antonio Gonsalves TEIXEIRA E SOUSA, Tomo II, op.cit., p.35.

${ }^{401}$ José Roberto TORERO, op.cit, p.116.

402 Ibidem, p. 157.

${ }^{403}$ Ibidem, p. 100.
} 
D. Amélia estava altiva, muito bela e harmoniosa num vestido de cetim branco. Seus cabelos muito negros e lustrosos, estavam puxados para trás, mas alguns cachos se acomodavam graciosamente sobre seus ombros". ${ }^{404}$ E ainda: "Sobrancelhas finas e arqueadas, olhos acesos, nariz equilibrado, boca desenhada, queixo fino e seios como os que Goya pintou. ${ }^{405}$

Sobre sua personalidade, é apresentada como uma mulher séria e extremamente ciumenta, mas sempre apoiando D. Pedro.

Percebe-se que nessa obra as representações sobre os personagens femininos pautam-se numa qualificação ou desqualificação com base na aparência física de cada uma delas, fator sempre explorado. E as mulheres são citadas a partir do relacionamento que mantinham com D. Pedro, como personagens coadjuvantes. O tipo de linguagem empregada (chula) nas descrições são próprias do estilo do livro, que caracteriza o personagem central, o Chalaça. E claro, lembro mais uma vez, que escritores possuem um compromisso diferente de historiadores e são livres para abusar da imaginação na construção de seus personagens. Assim, exploram as descrições da maneira que se adequem melhor à proposta e composição da obra.

Entretanto, é interessante sobretudo no caso das personagens femininas, pensar na contraposição tanto do quanto é explorada a relação do casal D. João e Carlota Joaquina, na construção da imagem negativa da última, e de D. Pedro e suas consortes, que não recebem o mesmo tratamento e destaque. D. Leopoldina e D. Amélia são retratadas como as esposas que fornecem suporte ao monarca e recebem um tratamento muito secundário se comparadas à Carlota. A última tornou-se figura marcante e polêmica na história e nas obras literárias, em geral, recebendo descrições ou sendo representada de forma pejorativa e cômica.

Assim, tento demonstrar como história, literatura e cultura de história se relacionam, através de um conjunto de conhecimentos comuns, da construção de um imaginário social partilhado; de uma memória coletiva; por um conjunto de produções culturais que tratam da história; pela produção historiográfica e por obras literárias que apresentam representações da história. Neste aspecto, a intertextualidade e as variadas

\footnotetext{
${ }^{404}$ Ibidem, p.80.
}

405 Ibidem, p.80 
leituras possuem um papel relevante, pois estão sempre em movimento, podendo expressar reafirmações ou modificações das representações da história. Em suma, a cultura de história se encontra numa estreita relação com a história e a literatura pois são dois campos de produção de narrativas/discursos. Em outras palavras, a Literatura tanto pode absorver representações da história derivadas do campo historiográfico, quanto pode engendrar representações que venham a ser de utilidade ou exercer certo impacto nos estudos historiográficos e no imaginário social.

A abordagem humorística da história é evidente em parte das obras aqui analisadas, o que chama a atenção. Elias Thomé Saliba, em sua obra Raízes do Riso ${ }^{406}$, embora mantenha o foco no período da Belle Époque, discorre como a abordagem humorística faz parte da cultura brasileira. Assim, essa análise do humor como componente da cultura brasileira se confirma. Ademais, parece constituir essa cultura de história brasileira também, embora outros tipos de abordagem sejam encontrados na mesma medida. Restaria saber se outros temas da história do Brasil também recebem este tratamento humorístico. No conjunto de obras que compreendem os objetos de análise dessa dissertação, essa abordagem da história através do humor é observada sobretudo nos romances. Na poesia, o humor é empregado no conjunto de poemas satíricos de Murilo Mendes, em História do Brasil (1932).

De acordo com Saliba, mesmo os tipos de abordagem humorística com a criação de estereótipos e caricaturas são próprios de cada nação:

Cada imaginação nacional, da mesma forma que produz a sua própria narrativa, produz também sua peculiar representação humorística; cada uma forja suas peculiares línguas e falas cômicas, que se expressam (...), naqueles estereótipos concisos, sintéticos e rapidamente inteligíveis, mas também cheios de subentendidos, de omissões, de silêncios e de "não-ditos. ${ }^{407}$

Não é novidade que governantes sejam retratados de forma cômica por artistas ou pela população. Essa pode ser, inclusive, uma forma muito comum de crítica a reis e rainhas, estadistas e políticos de maneira geral. Entretanto, temos como uma marca dessa cultura de história a representação humorística dos integrantes da Família Real, sobretudo, de D. João, D. Carlota Joaquina e D. Pedro. Se uma narrativa oficial construiu

\footnotetext{
${ }^{406}$ Elias Thomé SALIBA, op.cit., 2002.

407 Ibidem, p.31.
} 
a imagem ilustre da Família Real, e heróica de D. Pedro, surgiu uma outra narrativa que corrompeu essa imagem através do humor, da sátira, na forma burlesca, como uma maneira de rebaixamento da realeza. Nessa forma, o foco maior é a vida privada e intrigas palacianas e pessoais dos personagens. O tom elevado é afastado e são usadas descrições chulas, esdrúxulas, muitas vezes ridicularizantes, tais quais caricaturas como apontado tantas vezes. No que se refere ao objeto dessa pesquisa, representações da história na literatura, esse tratamento dispensado aos personagens da Família Real é amplamente utilizado nas obras publicadas a partir do século XX, e de acordo com a semelhança das descrições encontradas, possui uma forte referência no livro de Manuel de Oliveira Lima, D. João VI no Brasil. ${ }^{408}$

\subsection{Outros personagens}

Além dos personagens da Família Real, outras figuras históricas ganharam destaque nas obras ficcionais sobre a Independência. Os romances que tratam da Revolução Pernambucana, por possuírem também uma marca pedagógica para mostrar a relevância do projeto do governo autônomo que se instalou na província, também as insatisfações com a política econômica do Rio de Janeiro e resgatar essa memória, tendem a fornecer descrições de cada um dos participantes da revolução, sobretudo seus líderes. Essas descrições possuem referência historiográfica escrita por uma testemunha ocular dos eventos, o monsenhor Muniz Tavares e sua História da Revolução de Pernambuco de 1817, e que ganhou edição comemorativa no centenário da revolução, revista e anotada por Oliveira Lima. Este evento possui destaque menor em livros didáticos, sem ênfase na descrição dos personagens. Assim, A noiva da Revolução (2006) e Olhos Negros (2009) reivindicam a importância da Revolução Pernambucana na história e memória nacional. Além disso, as duas obras, como já destacado, possuem uma forte marca didática e instrutiva. Com isso, dedicam-se a construir a imagem dos revolucionários apresentando descrições físicas, redes de contatos e compondo traços de personalidade. A ilustração dos revolucionários, o engajamento nas causas da revolução, a luta pela liberdade e projeto autônomo da província de Pernambuco centram a narrativa dos livros. É necessário ressaltar que embora essas obras tenham sido escritas com enredos cujos personagens são os sujeitos históricos, são romances. Portanto, o dado fíctício e

${ }^{408}$ Wilson MARTINS. "Um clássico da historiografia nacional". In: Manoel Oliveira LIMA. D. João VI no Brasil...cit, p.14. 
imaginativo tem que ser levado em conta.

No caso de Olhos Negros (2009), cada capítulo é destinado à descrição de um personagem e a relação que possuía com a narradora - e única personagem fictícia do livro de acordo com a escritora. É a partir do olhar de Maricotinha e suas memórias que a história vai sendo contada. Assim, ela insere cada personagem, aponta o papel que teve na Revolução Pernambucana e discorre sobre a formação, atuação e conexões políticas e ilustradas. Caso o personagem tenha sido executado, narra como isso ocorreu. Embora, seja claro que autor e narrador são distintos em obras literárias, nessa obra, a narradora parece ser a voz da autora também. Segundo consta na pequena biografia de Maria Cristina de Albuquerque na contracapa do romance, a autora é historiadora e romancista, ex-presidente e sócia efetiva do Instituto Arqueológico, Histórico e Geográfico de Pernambuco. Como exemplo, cito o comentário que Maricotinha, a narradora, faz do livro que Francisco Muniz Tavares escreveu 409: "Pelo que podia entender, pretendia dar ao personagem de meu padrinho o destaque devido ao papel que representou na tragédia. Atualmente havia uma curiosa tendência a tornar sua passagem por essa revolução menos distinta ou importante." $410 \mathrm{O}$ "atualmente" da narradora se passa em março de 1869, ainda século XIX, a pergunta que fica é se naquela época já havia uma tendência a diminuir a memória da participação do Padre João Ribeiro, o padrinho da narradora, ou se essa frase foi colocada de forma anacrônica pensando na memória de início do século XXI, quando foi publicada a primeira versão do livro de Maria Cristina Albuquerque.

É interessante que, se em Olhos Negros (2009), apenas a narradora é um personagem fictício, em A noiva da Revolução (2006), de Paulo de Oliveira, a narradora também é um personagem histórico, aliás citado em Olhos Negros. Maria Teodora é a narradora de A noiva da Revolução, a jovem que teve um breve casamento com Domingos José Martins, um dos líderes da Revolução Pernambucana. O namoro escondido e proibido, e o casamento com o episódio em que a noiva (Maria Teodora) apareceu com seu cabelo "à la Tito, bem curtinho, tal como o das francesas dos tempos revolucionários" ${ }^{411}$, incitando outras mulheres a fazerem o mesmo pela República de Pernambuco, é contado de forma breve no livro de Maria Cristina. Em Olhos Negros,

\footnotetext{
${ }^{409}$ Livro que existe de fato e que teve sua primeira edição publicada em 1840, pela Typographia Imparcial de L.F.R.Roma. Deixo aqui a referência da terceira edição: Francisco Muniz TAVARES, História da Revolução de Pernambuco em $1817,3^{\mathrm{a}}$ edição comemorativa do $1^{\circ}$ Centenário (Revista e anotada por Oliveira Lima). Recife: Imprensa Industrial, 1917.

${ }^{410}$ Maria Cristina C. de ALBUQUERQUE, op.cit., p.66.

${ }^{411}$ Paulos Santos de OLIVEIRA, op.cit., p.162.
} 
Maricotinha, a narradora cortou os cabelos seguindo o exemplo de Maria Teodora, esposa de Domingos José Martins, um dos líderes da revolução. ${ }^{412}$

No livro de Paulo de Oliveira, A noiva da Revolução (2006), a trama gira em torno dos escritos que Domingos José Martins fez sobre a revolução, que Maria Teodora encontra e resolve completar. Assim, temos em boa parte do romance as duas vozes intercaladas. Com isso, o foco gira em torno de Domingos José Martins e os líderes da revolução, e os planos, viagens, discussões políticas. As descrições e apresentações dos personagens são feitas por Maria Teodora.

De forma sumária, na voz da narradora Maria Teodora, há um balanço dos personagens e revolucionários de Pernambuco:

Um alto oficial português, em conversa comigo, reconheceu que os revolucionários foram homens dignos, de comportamento exemplar. Eles não confiscaram bens, não perseguiram e - espantosamente! - não condenaram ninguém à morte; exceto os três ou quatro desertores executados pelo coronel Pedroso, à revelia dos governantes. E nas ruas quase não houve roubos nem assaltos durante a vigência do Provisório, ao contrário do que havia antes e tornou a haver depois. Se algum erro cometeram, foi o do amadorismo político. Não deveriam ser castigados daquela maneira. ${ }^{413}$

Neste trecho fica claro o valor atribuído não apenas aos revolucionários, mas também à revolução: destaca-se o caráter pacífico e atitudes exemplares dos envolvidos. De acordo com a narradora, o erro que levou ao fracasso da revolução teria sido a falta de experiência dos que a levaram a cabo. Um comentário que poderia parecer irrelevante se desconsiderarmos que se alinha a uma vertente e disputa historiográfica. Aqui me refiro à versão da revolução de Pernambuco explicada na obra do General Abreu e Lima, e a disputa historiográfica com Varnhagen (não apenas sobre a memória e importância da revolução, mas também sobre a Independência) ${ }^{414}$. Para Varnhagen, o movimento era

\footnotetext{
${ }^{412}$ Maria Cristina C. de ALBUQUERQUE, op.cit., p.59-61.

${ }^{413}$ Paulo Santos OLIVEIRA, op.cit., p.336.

${ }^{414}$ As obras em questão são: José Ignácio ABREU E LIMA, Compendio da História do Brasil, Tomo I e II. Rio de Janeiro: Casa dos Editores Eduardo e Henrique Laemmert, 1843. E Francisdo de A. VARNHAGEN, História Geral do Brasil antes de sua separação e independência de Portugal. Tomo I e II. Rio Janeiro: Casa e E. \& H.Laemmert, 1854. Os capítulos que tratam da Revolução Pernambucana encontram-se no Tomo I na obra de Abreu e Lima; e no Tomo II na de Varnhagen. Quem ilumina a disputa historiográfica em torno da Revolução Pernambucana é: Thamara de Oliveira RODRIGUES, "A revolução Pernambucana e as disputas historiográficas: Abreu e Lima e Francisco Adolfo de Varnhagen”. In: História e Cultura, Franca, v.6, n.1, p.289-308, mar.2017. Neste artigo a pesquisadora também apresenta um balanço
} 
isolado do processo de Independência, de caráter unicamente regional, sem um projeto e destacava sua violência. E a revolução só teria alcançado algum sucesso inicial devido a má administração do governador Caetano Pinto de Miranda Montenegro. Para Abreu e Lima, destacava-se o caráter pacífico dos revolucionários em oposição à violência dos realistas, e teria sido a presença de elementos conservadores que barraram o avanço da revolução. ${ }^{415}$

Neste aspecto, a obra Olhos Negros (2009) não se distancia do romance A noiva da Revolução (2006), pelo contrário, um dos capítulos é dedicado ao General Abreu e $\mathrm{Lima}^{416}$, que no romance é o amante/companheiro da narradora "Maricotinha". O tempo presente da narrativa, 1869, momento em que a narradora rememora e conta sobre a revolução, se passa em virtude da cerimônia em que os restos mortais de Abreu e Lima seriam enterrados no Cemitério dos Ingleses, no Recife, anos após sua morte. Há críticas explícitas a Varnhagen no livro de Maria Cristina de Albuquerque. No trecho a seguir destaca-se o atrito de Abreu e Lima com Varnhagen:

Outra história aborrecida. [Abreu e Lima] Atritara-se com o cônego Januário da Cunha Barbosa e com o historiador Francisco Adolfo de Varnhagen, visconde de Porto Seguro. O general talvez não fosse o historiador mais purista, o pesquisador mais isento. Seu caráter impulsivo e apaixonado, seu gosto pelas ideias em prejuízo dos fatos faziam-no escrever e interpretar a história de modo diferente. Varnhagen, guiando-se por critérios estritamente conservadores, parecia desconhecer que existem questões ideológicas em litígio, muitas vezes levadas ao âmbito pessoal. O curioso é que este historiador acurado e isento terminou confessando, a propósito da Revolução de $1817 \ldots " . . " 117$

Ao fim desse parágrafo, foi colocada a citação de Varnhagen que preferia deixar a Revolução Pernambucana fora de seu livro ${ }^{418}$. Temos, portanto, história, literatura e

\footnotetext{
historiográfico sobre a Revolução Pernambucana, e seu "esquecimento" na narrativa nacional, se comparada com a "Conjuração Mineira".

415 Thamara de Oliveira RODRIGUES, op.cit., p.296-306.

416 José Ignácio de Abreu e Lima era filho do Padre Roma, cujo nome era José Inácio Ribeiro de Abreu e Lima, que foi um dos líderes da Revolução Pernambucana, sendo executado por isso. José Ignácio ABREU E LIMA, Compendio da História do Brasil, Tomo I. Rio de Janeiro: Casa dos Editores Eduardo e Henrique Laemmert, 1843, p.283-285. Ver também: Thamara de Oliveira RODRIGUES, op.cit, p.296.

${ }^{417}$ Maria Cristina C. de ALBUQUERQUE, op.cit., p.33-34.

${ }^{418} \mathrm{O}$ trecho foi colocado no romance com padrão de citação: "É um assunto para nosso ânimo tão pouco simpático que, se nos fora permitido passar sobre ele um véu, o deixaríamos fora do quadro que nos
} 
historiografia misturadas, e conectadas de forma acentuada nesses dois romances. Assim, o romance manifesta a defesa da história da Revolução de Pernambuco de 1817, sua importância, sua memória e destaca-se o aspecto didático que possuem. Se a história da Revolução de Pernambuco de 1817 recebeu ao longo do tempo destaque menor e certa marginalização na narrativa nacional, produto inclusive de parte da historiografia e livros didáticos, esse fenômeno foi percebido. No século XXI ocorreu um movimento de retomada dessa história e memória, e revisão na historiografia. ${ }^{419}$ Esse movimento seria indicativo de um resgate da história e memória da revolução de Pernambuco de 1817, devido uma "interdição" da história por parte da historiografia? A publicação de romances com uma característica tão evidente de instrução da revolução de Pernambuco, dialogando diretamente com a historiografia poderia indicar que sim. Um argumento que poderia confirmar essa hipótese, são os estudos que destacam a evidência dada à Inconfidência Mineira e Tiradentes em comparação com a Revolução Pernambucana e Frei Caneca. ${ }^{420}$

Na obra de Murilo Mendes, História do Brasil (1932), constam dois poemas que contemplam a Revolução de Pernambuco, são eles: "A mão de Domingos José Martins" e "Relíquias de Frei Caneca". O último trata da execução de Frei Caneca, em 1825, após sua participação na Confederação do Equador em 1824, e não apresenta uma descrição do personagem, mas o momento da sua execução. Sobre o primeiro poema, também não há uma descrição de Domingos José Martins. O poeta discorre sobre a execução, esquartejamento e exposição das cabeças e mãos dos participantes da Revolução Pernambucana, e através de um sonho ou visão com a mão ensanguentada de Martins, D. João VI tem um presságio sobre o que aconteceria com seu reino: seria dividido, ele teria que sair do Brasil e seus descendentes não teriam sossego, pois as cabeças que ele mandara cortar renasceriam com mais força. ${ }^{421}$

propusemos traçar (...).” Em: Maria Cristina C. de ALBUQUERQUE, op.cit., p.34. A citação original pode ser encontrada em: Francisco Adolfo de VARNHAGEN, História Geral do Brazil antes da sua separação e independência de Portugal. Tomo II. Rio de Janeiro: E\&H Laemmert, 1877, p.1115.

${ }^{419}$ Não apenas as obras literárias que nesta dissertação são objeto de investigação mas o artigo de Thamara Oliveira demonstra uma retomada de questionamentos sobre essa obliteração da Revolução de $1817 \mathrm{em}$ Pernambuco, por parte da historiografia. Consultar: Thamara de Oliveira RODRIGUES, “A Revolução Pernambucana e as disputas historiográficas: Abreu e Lima e Francisco Adolfo de Varnhagen”.In: História e Cultura, Franca v.6, n.1, p.289-308, mar.2017.

${ }^{420}$ Ibidem, 2017. Consultar também: Mariana dos Santos RIBEIRO, "Frei Caneca e a Confederação do Equador”. In: Revista Intellèctus, v.5, n.2, 2006.

${ }^{421}$ Murilo MENDES. “A mão de Domingos José Martins”, op.cit, p.39. O verso: "Teu reino será dividido,/ Terás que sair daqui;/ Teus descendentes, ô rei,/ Serão sempre desgraçados,/ Nenhum sossego terão;/ As cabeças que você/ Mandou cortar/ renascerão com mais força”. 
Três participantes foram mutilados e suas cabeças expostas em diferentes lugares em Pernambuco ${ }^{422}$, por esse motivo o título do poema se refere à mão de Domingos José Martins $^{423}$, que aludem às execuções:

O rei português mandou/ Cortar sem pena as cabeças/ De cem brasileiros bons,/ Gente decente, sem medo,/ Sabendo ler e escrever,/ Costumando tomar banho,/ Sem jeito para ser escrava. O carrasco decepou/ A cabeça dos heróis,/ As pernas mandou cortar,/ Em seguida as mãos também; ${ }^{424}$

Aos revolucionários é dispensado o tratamento por heróis, destemidos e instruídos, e é ressaltado como D. João foi impiedoso nas punições pelo levante contra seu governo. ${ }^{425}$ E ocorre o "presságio" através do sonho de que a luta seria retomada num futuro, com os descendentes de D. João, assim, o projeto de "independência", ou o projeto "republicano" seria resgatado.

No caso das lutas da Independência na Bahia, destaco três personagens que são consideradas heroínas: a abadessa Joana Angélica; Maria Quitéria; e a cabocla Paraguassú ${ }^{426}$. O épico de Ladislau dos Santos Titara, Paraguassú (1835 e 1837), tem como personagens centrais os combatentes nas lutas da Bahia em 1822 e 1823, e o

\footnotetext{
${ }^{422}$ De acordo com Abreu e Lima além da execução de seu pai, o Padre Roma, as execuções deram-se da seguinte forma: Domingos José Martins, José Luiz de Mendonça e o Padre Miguel Joaquim de Almeida e Castro foram fuzilados na Bahia. Em Pernambuco, o tenente Antonio José Henriques, o padre Pedro de Sousa Tenório, e os capitães José de Barros Lima e Domingos Theotonio Jorge foram enforcados e mutilados, o primeiro teve sua cabeça exposta na ponte de Recife, os outros três tiveram suas cabeças expostas em diferentes lugares. Na Paraíba, o coronel Amaro Gomes Coutinho, o Ignacio Leopoldo de Albuquerque Maranhão, padre Antonio Pereira, e os tenentes coronéis Silveira e José Peregrino de Carvalho foram igualmente enforcados e tiveram suas mãos e cabeças mutiladas para serem expostas nas estradas da Paraíba.Em: José Ignacio ABREU E LIMA, Compêndio da História do Brasil, Tomo I. Rio de Janeiro: Casa dos Editores Eduardo e Henrique Laemmert, 1843, p.291- 295.

${ }^{423}$ Licença poética do autor para o título do poema pois como apresentado na nota anterior, Domingos José Martins foi fuzilado na Bahia e Domingos Theotonio Jorge enforcado, e teve cabeça e mãos esquartejadas como outros dois revolucionários. Assim como os participantes executados na Paraíba, também com as partes expostas nas cidades.

${ }^{424}$ Murilo MENDES, op.cit.,p.38.

${ }^{425}$ Como destaquei a comparação entre Inconfidência Mineira e Revolução Pernambucana, indico que no livro de poemas História do Brasil, de Murilo Mendes, há também dois poemas dedicados à Inconfidência Mineira. São eles: "O Alferes na cadeira", que conforme notas de Luciana Stegagno Picchio, apresenta uma contraposição de Tomás Antônio Gonzaga e Joaquim José da Silva Xavier (Tiradentes) contra o poder central de Lisboa. E "A estátua do Alferes" que remete a estátua de Tiradentes na frente da Câmara dos Deputados do Rio. Informações em: Murilo MENDES. História do Brasil (1932). Luciana Stegagno Picchio (org., introdução e notas), p.99-100.

${ }^{426}$ Sobre a importância dessa personagem na Bahia, ver: Gerson Galo LEDEZMA. "Religiosidade Cívica na Bahia: Comemorando o Primeiro Centenário da Independência a 2 de Julho de 1923". Entre a memória nacional e a memória regional. Esboços: histórias em contextos globais, Florianópolis, v. 16, n. 21, p. 6987, mar. 2009.
} 
Visconde de Pirajá, a quem o poema é dedicado. Não temos um herói, mas figuram heróis nessa epopeia, os que lutaram para expulsar as tropas de Portugal da Bahia. A luta começou sob o comando do Visconde de Pirajá ${ }^{427}$, e terminou chefiada pelo General em Chefe Lima.

O episódio que consagrou Joana Angélica ao status de heroína foi seu assassinato por soldados do general Madeira. De acordo com uma memória difundida popularmente, com o intuito de proteger as religiosas que se encontravam reunidas no mosteiro, ao perceber que a porta seria arrombada por homens das tropas favoráveis à manutenção do vínculo com Portugal, Joana Angélica se colocou no caminho dos soldados e foi assassinada por baionetas. ${ }^{428} \mathrm{Na}$ epopeia de Titara, o episódio é narrado na forma poética, e em nota há o esclarecimento que se trata da abadessa do Mosteiro da Lapa da Bahia, Joana Angélica:

Ao horrendo fremir das rijas portas.

Intrépida Heroína, acorre Antiste ${ }^{429}$,

A que do sacro Encerro a paz cabia;

E porque a sanha acalme aos monstros, única

O postigo desfacha [sic], e ora mil preces

Exaure a eliminá-los; ora ativa

Empresa suasões, e às cans[sic] ostenta, ${ }^{430}$

(...)

O empecilho em dobro, e prerrompendo

Sem pio ardor, sem dó, descridos [sic]cravam

Com a morte o gume no virginio seio,

Que viste infortunosa cair, Lapa, ...431

\footnotetext{
${ }^{427} \mathrm{O}$ autor acrescentou nota explicativa indicando que se trata do "Ajudante General Coronel Joaquim Pires de Carvalho e Albuquerque, o actual Visconde de Pirajá". Ladislau dos Santos TITARA, Paraguassu: Epopeia da Guerra da Independência na Bahia. São Paulo: Empresa Gráfica da Revista dos Tribunais, 1973, p.292-292.

${ }^{428}$ Bernardino José de SOUZA, Heroínas Bahianas: Joanna Angélica, Maria Quitéria, Anna Nery. Rio de Janeiro: Paralelo; Brasília: Instituto Nacional do Livro, 1972. Neste livro o autor transcreve a descrição de alguns documentos que relataram a morte da abadessa e discorre sobre as personagens, de forma apaixonada, enaltecendo-as.

${ }^{429} \mathrm{O}$ autor acrescentou nota esclarecendo que se trata da Abadessa do Mosteiro da Lapa da Bahia, D. Joana Angélica. Ladislau dos Santos TITARA, op.cit, p.189.

${ }^{430}$ Ladislau dos Santos TITARA, op.cit., p.189.

${ }^{431}$ Ibidem, p. 190.
} 
Como é possível perceber, há uma construção do poema de forma a narrar tal qual o episódio ficou conhecido e que elevou a Abadessa Joana Angélica à posição de heroína da Guerra da Independência na Bahia. E na epopeia a "angelica Vestal"432 é tratada por seu heroísmo ao enfrentar os soldados das tropas inimigas que invadiram o mosteiro.

No épico de Teixeira e Sousa, Independência do Brasil (1847 e 1855), a morte da abadessa também foi lembrada:

(...) E a Abadessa a seu Deus humilde, e fida/ Traspassada d'um ferro, cai sem vida!

Oh morte mais que todas gloriosa!/ Tomba sem murmurar e expira calma! Santa na morte, em vida virtuosa,/ Entre anjos volve ao céu tão feliz alma!/ Vai do Esposo do céu pura, e ditosa/ Receber do martírio a eterna palma!/ Angélica em tua alma, e até no nome./ Alma aos anjos, e a nós o teu renome! $!^{433}$

Da mesma forma, a construção poética apresenta o episódio em que Joana Angélica foi morta. Embora não receba a alcunha de heroína a memória do episódio e seu nome é realçado. Na sequência dos versos, o poeta também narra sobre o padre que foi espancado nesse episódio e finaliza: "Não graveis por piedade, ó escritores,/ Sobre as solenes páginas da História/ Estes infandos tétricos horrores,/ Esta infamante, e pérfida vitória...!"434 Assim, relembra a característica tão marcante da sociedade portuguesa, sua cristandade.Talvez por esse motivo este episódio seja relembrado, pois a violência dos "portugueses", católicos devotos, se voltou contra as religiosas escondidas no mosteiro, ou seja, não ofereciam qualquer tipo de ameaça às tropas comandadas por Madeira.

Em Paraguassú (1835 e 1837), encontramos versos e referência à Maria Quitéria de Jesus em nota de 20 de agosto de 1823: "deu-se o soldado de Alferes de Linha, sobre a condecoração do Cruzeiro" "435. À Maria Quitéria é destacado o tratamento como guerreira, seu heroísmo e sua coragem, "férvida Amazona" ${ }^{436}$, ela que "às Baianas d'aqui realça a glória" 437 .

\footnotetext{
${ }^{432}$ Ibidem, p. 191.

433 Antonio Gonsalves TEIXEIRA E SOUSA, Tomo II op.cit., p.112.

${ }^{434}$ Ibidem, p. 113.

${ }^{435}$ Ladislau dos Santos TITARA, op.cit., p.427.

${ }^{436}$ Ibidem, p.428.

${ }^{437}$ Ibidem, p.428.
} 
“...Contíguas posições, por fim investem/ À do Paraguassú fóz, em que Victor,/ Valente defensor, vigia ativo/ As trêtas abrogar-lhes.[sic] Mais reteimam/ Aqui as hostis proas; porém forte/ Barreira opõe-lhes os Patrícios peitos,/ E armígeras Bahianas, que terríveis/ Do frágil sexo deslembrando[sic] o mimo,/ Os aguardam na praia, iras nutrindo."

"Tu, destemida Penthesilia [sic] heroica,/ Tinda de iras, rancor, e toda fogo,/ Mais e mais n'alma d'elas sopras flamas, / E, exemplas condutora á todas bradas..." 438

Nesses versos há indicação de que Maria Quitéria comandava, ou servia de exemplo para outras mulheres que lutavam com ela. Supostamente, Maria Quitéria fingiu ser um homem porque mulheres não eram aceitas nas tropas. Portanto, pode ser uma construção poética do escritor, ou como Titara participou das batalhas na Bahia, poderiam ter outras mulheres lutando.

Nos marcos de memória da Independência da Bahia também temos a figura da Cabocla, a índia Paraguassú, ou filha de Paraguassú. Figura feminina ligada não apenas à exaltação baiana mas também ao símbolo de uma raiz nacional: o indígena. Na epopeia de Titara, Catharina Paraguassú também foi contemplada, cito aqui a longa nota que o autor escreveu sobre o episódio:

D. Catharina Alves Paraguassú, que, vendo quanto o impolítico, e desumano Donatário Francisco Pereira Coutinho, não só espezinhava os Índios, sendo até desapiedadamente assassinados, como, também se arrojava a, menos-cabando sua hierarquia (está grafado Gerarchia), deprimí-la, e a seu Esposo, a quem fazendo prender, sem motivo, recolhera a um navio, graçando logo a notícia de o terem assassinado; fez de repente reunir os seus conterrâneos, e a testa deles, dos Tamoyos, e d'outras tribos, que chamara do Recôncavo, sitiou a Cidade e depois de sanguinolentas ações, e forte resistência de Coutinho, que perdera nelas um filho, o puseram em fugida com todos os seu, que abrigando-se a bordo dos navios, escaparam-se para os Ilhéus, ficando a Bahia livre de tais verdugos. ${ }^{439}$

\footnotetext{
${ }^{438}$ Ibidem, p. 427.

${ }^{439}$ Ladislau dos Santos TITARA, op.cit, Canto IV, p.227-228. Foram preservados itálico e maiúsculas do texto original.
} 
É interessante que as três personagens celebradas e que entraram para os marcos heróicos da Bahia, sejam femininas. O que se contrapõe à memória nacional (que se pretende oficial), em torno das ações de D. Pedro I e seus conselheiros, cujas mulheres são coadjuvantes. E no caso de Carlota Joaquina que possui destaque, é representada e lembrada de forma pejorativa. Sóror Joana Angélica e Maria Quitéria também são conhecidas na história nacional, já Paraguassú, é celebrada mais regionalmente. ${ }^{440}$ Nas versões nacionais que citam as heroínas baianas, a cabocla Paraguassú possui destaque menor ou nem é mencionada.

Em suma, na epopeia de Ladislau dos Santos Titara, a figura de D. Pedro embora citada e celebrada possui evidência menor frente aos heróis e heroínas homenageados. São eles: os voluntários que lutaram nas batalhas que expulsaram as tropas de Portugal da Bahia; o Visconde de Pirajá; a Sóror Joana Angélica; Maria Quitéria de Jesus; Catharina Paraguassú; e as atuações de Labatut ${ }^{441}$ e Lima e Silva ${ }^{442}$, assim como os anônimos que lutaram nas tropas libertadoras.

A obra de João Ubaldo Ribeiro, Viva o povo brasileiro ${ }^{443}$ (1984), possui recorte amplo passando por vários momentos da história do país, dentre eles a Independência, e as lutas que expulsaram as tropas de Portugal da Bahia, em 1823. ${ }^{444}$ Os personagens

\footnotetext{
${ }^{440}$ Sobre as comemorações da Independência na Bahia no 2 de julho, que destacam a figura da cabocla Paraguassú consultar: Hendrik KRAAY, “'Frio como a pedra de que se há de compor': caboclos e monumentos na comemoração da independência na Bahia, 1870-1900". In: Tempo (Niterói. Online), v. 7, p. 51-81, 2003.

${ }^{441}$ Trata-se do general Pedro Labatut. De origem francesa, foi contratado por D. Pedro I para organizar e liderar o exército pacificador nas guerras pela Independência na Bahia. Sobre o assunto consultar: Pedro LABATUT, Defeza do General Labatut, sobre a sua conducta em quanto commandou o exercito pacificador da Bahia, em resposta aos quatro artigos das accuzação, que lhe forão communicados por ordem do conselho de guerra; a quem tem já respondido por determinação de S.M.I. Rio de Janeiro: Typographia de Silva Porto e Companhia, 1824.(foi mantida a grafia original do título)

${ }^{442}$ Trata-se de de Luiz Alves de Lima e Silva, Duque de Caxias. Sobre o personagem: Padre Joaquim Pinto dos CAMPOS, Vida do grande cidadão brazileiro Luiz Alves de Lima e Silva: barão, conde, marquez, duque de Caxias, desde o seu nascimento em 1808 a 1878. Lisboa: Imprensa Oficial, 1878; Adriana Barreto de SOUZA, Duque de Caxias: o homem por trás do monumento. Rio de Janeiro, Civilização Brasileira, 2008; Adriana Barreto de SOUZA, "Experiência, configuração e ação política: uma reflexão sobre as trajetórias do duque de Caxias e do general Osório". In: TOPOI, v.10, n. 19, jul.-dez. 2009, p. 90-111.

${ }^{443}$ João Ubaldo RIBEIRO. Viva o povo brasileiro. Rio de Janeiro: Objetiva, 2014. Foi utilizada nesta dissertação a $6^{a}$ edição, comemorativa dos 30 anos de publicação da obra. A primeira edição foi publicada em 1984.

${ }^{444}$ Para bibliografia do tema consultar: Carlos Guilherme MOTA. "O Processo de Independência na Bahia". In: 1822: Dimensões. São Paulo: Editora Perspectiva, 1986, p.231 - 250; Breno F. De AMARAL, A Guerra da Independência da Bahia: 1823. São Paulo: M. Lobato, 1923; José Wanderley de A. PINHO, "A guerra da independência (crônica de toda a campanha)". In: Revista do Instituto Histórico e Geográfico Brasileiro. Rio de Janeiro, volume 278, jan-mar. 1968, p. 35-86; Braz do AMARAL, História da Independência na Bahia. $2^{\text {a }}$ ed. Salvador: Livraria Progresso editora, 1957; Hendrik KRAAY, Política racial, Estado e forças armadas na época da Independência: Bahia, 1790-1850. São Paulo: Hucitec, 2011;; Hendrik KRAAY, "Entre o Brasil e a Bahia: as comemorações do Dois de Julho em Salvador, século XIX". In: Afro-Ásia, v.23, p.48-87, 2000; Thomas WISIAK, Itinerário da Bahia na Independência do Brasil (1821-1823). In: István JANCSÓ (org.) Independência: História e historiografia. São Paulo: Fapesp: Hucitec, 2005, $447-$
} 
históricos são citados (como D. João, D. Pedro, Maria Felipa e Joana Angélica, dentre outros), e foram construídos personagens que configuram tipos dessa sociedade escravista. A trama da obra gira em torno das identidades e projetos idealizados para o Brasil. As relações entre uma classe dominante e os homens e mulheres escravizados, subalternos e o povo formam o centro da narrativa. Os personagens que participaram das lutas da independência na Bahia são citados, porém, personagens fictícios foram criados apresentando uma história que desconstrói o mito de heróis da Independência.

A luta em Itaparica é lembrada em passagem mais avançada na narrativa da obra, no momento em que ocorre a Guerra do Paraguai $(1864-1870)^{445}$. O personagem João Popó discursaria nas comemorações do Sete de Janeiro, data em que se comemora a expulsão das tropas de Portugal ("a malta opressora"446) de Itaparica, e se refere aos itaparicanos como aqueles que " outra vez salvariam a Pátria e preservariam sua integridade" ${ }^{447}$. Quando se refere aos personagens históricos saúda Maria Felipa, a Sóror Joana Angélica e Lorde Cochrane. Estes que recebem vivas são apresentados como heróis, em contraposição ao "opressor lusitano, o invasor holandês e Madeira"448. Estes personagens e eventos são apenas citados, em tom de "Viva" ou "Abaixo", o que demonstra o valor que possuem. A Independência do Brasil, a Pátria e D. Pedro II também são celebrados recebendo vivas. Portanto, esses momentos históricos e personagens ganham um destaque importante, embora na linha do tempo do romance a menção é lembrada no momento em que ocorria a Guerra do Paraguai.

474; Richard GRAHAM, “"Ao mesmo tempo sitiantes e sitiados”. A luta pela subsistência em Salvador (1822-1823)”. In: István JANCSÓ (org.) Independência: História e historiografia. São Paulo: Fapesp: Hucitec, 2005, p.411-445.

${ }^{445}$ Uma referência sobre a Guerra do Paraguai é: Francisco DORATIOTO, Maldita Guerra: nova história da Guerra do paraguai. São Paulo: Companhia das Letras, 2007.

446 João Ubaldo RIBEIRO, op.cit., p.403.

${ }^{447}$ Ibidem, p.410. O episódio se passa em Ponta das Baleias em 07 de janeiro de 1865. Quando se refere à atuação dos itaparicanos João Popó diz: [os itaparicanos] Já tinham feito isto [salvar a Pátria] contra os holandeses, contra corsários de todas as nações, contra os opressores lusitanos, fá-lo-iam agora contra o infame inimigo paraguaio..." Neste trecho o personagem se refere aos "heróis pretéritos, itaparicanos ou homens de raízes da ilha - Barros Galvão, João das Botas, o Barão de Pirapuama, um verdadeiro e injustamente esquecido guerreiro e estadista da Independência, tantos outros que a História não haveria de relegar ao olvido...". Destaco que em 1867 momento em que se passa a cena surge o indício que, se em 1822 e 1823 o Barão de Pirapuama era considerado herói, foi perdendo importância com a passagem do tempo. (p.410)

${ }^{448}$ Ibidem, p.410. 


\subsection{Personagens Fictícios: a desconstrução do mito de heróis em Viva o povo}

\section{brasileiro}

Até aqui acompanhamos algumas abordagens convencionais sobre a Independência e seus personagens, que compõem a cultura de história brasileira. Existe uma versão que se liga de forma mais direta a uma memória oficial construída em torno do centro-sul, da Família Real e um séquito de conselheiros, tratada de forma elevada. Uma outra abordagem cômica, normalmente utilizando da sátira, algumas vezes com emprego de linguagem chula, destacando eventos e características ridículas ou supostamente engraçadas, para rebaixamento dos personagens e história. Essa forma de tratamento da própria história, como já demonstrado, também é muito característica da cultura de muitos países, e também integra a cultura de história do Brasil. São formas muito próprias de cada nação no tratamento da própria história e seus conflitos. E também foi possível perceber como essas representações se ligam muito à historiografia. Essas conexões podem ocorrer de forma direta e/ou indireta (através de intertextualidades) conscientes ou não. Em Viva o povo brasileiro (1984), temos ainda uma outra maneira de abordar a história. A obra propõe provocações que estimulam reflexões sobre a escrita da história e da construção da memória e narrativas heróicas.

O primeiro trecho destacado se refere a um diálogo da professora Dona Jesuína com Maria da Fé (Dafé), que admirava o quadro do alferes Brandão Galvão que morreu lutando na Bahia, nas lutas da Independência:

Dona Jesuína considerava todo aquele interesse um exagero. Afinal, muitos e bem mais valorosos heróis era necessário cultuar, o Brasil não devia sua Independência somente àquele bravo, mas tantos outros que sua enumeração se tornava impossível. Pensasse Dafé que éramos um grande Império - sabia lá o que era um Império, podia avaliar a grandeza desse conceito? -, imaginasse a figura alta, imponente, portentosa mesmo, de Sua Majestade Imperial, Dão Pedro de Alcântara João Carlos Leopoldo Salvador Bibiano Francisco Xavier de Paula Leocádio Miguel Gabriel Rafael Gonzaga, da grande Casa de Bragança, nos seus verdes quinze anos já tão sábio quanto o Menino Jesus entre os doutores e com ele até parecido, em seu alvo semblante de meiguice. (...) Não imaginasse Dafé que esses homens eram gente como elas. Eram homens muito fora do ordinário, homens que com uma palavra ou olhar moviam multidões, homens que não dormiam meses a fio, 
carregando em seus peitos destemidos as dores da Nação, cuja virtude se comparava à dos grandes mártires, cujas palavras eram sempre de bravura, desprendimento, valentia, abnegação, devoção e sobretudo amor ao Brasil. Recordasse os exemplos de coragem inquebrantável, de caráter incorrompível, abundantes em cada pequeno episódio de nossa História, assistindo sublime razão ao poeta que rendeu graças aos Céus por tão bem nos aquinhoar de homens admiráveis. ${ }^{49}$

Neste longo trecho, a ideia contida se aproxima muitos à composição dos poemas épicos, ou seja, uma caracterização heróica e altiva dos grandes personagens que lutaram pelo Brasil. Homens fora do comum, e também o destaque na descrição de Dom (Dão) Pedro, nesse caso trata-se de D. Pedro II. No trecho é feita referência aos épicos, não apenas no tipo de imagem e descrições que cria, mas também com a menção ao "poeta que rende graças aos céus" "450. Há um afastamento desses "heróis" de pessoas mundanas, comuns, ordinárias na descrição feita pela professora. D. Pedro se "agiganta" inclusive em dimensões físicas, vira uma figura "alta e imponente, que move multidões com um olhar." ${ }^{451}$ O episódio da conversa da professora com Dafé, se passa em 1840, e a abordagem elevada é compatível com o tratamento da época para designação do Imperador e grandes sujeitos que entrariam para a História, como foi possível verificar nos poemas épicos aqui analisados.

Trabalhando com uma proposta de João Ubaldo de desconstrução dessa imagem, cito o caso do personagem Perilo Ambrósio, o Barão de Pirapuama, um personagem fictício e um dos centrais de Viva o povo Brasileiro (1984). No enredo do livro, Perilo Ambrósio, em Pirajá, acompanhado de dois escravos que lhe faziam companhia, Inocêncio e Feliciano, descansava afastado da batalha que ocorria entre tropas baienses e de Portugal. Esperava que as tropas do Brasil vencessem para então se juntar a elas. Observa um grupo de combatentes se aproximando e percebendo que se tratavam de tropas do Brasil, arma uma farsa: mata Inocêncio para banhar-se em sangue e simular ferimentos de combate. Vai ao encontro do tenente que acompanhava o grupo, escorandose em Feliciano. Como recompensa por "lutar pela causa da pátria" ganhou o título de Barão e tornou-se senhor de grandes propriedades, negócios de pesca de baleias, e proprietário de muitos cativos na região do Recôncavo Baiano. Alcançou muito

\footnotetext{
${ }^{449}$ João Ubaldo RIBEIRO, op.cit., p.289-290.

450 Ibidem, p.289-290.

451 Ibidem, p.289-290.
} 
reconhecimento público e influência política. Ficou conhecido e entrou para a história, na trama desta obra, como herói da Independência. Para que ninguém soubesse o que ocorreu verdadeiramente (o que de fato havia se passado naquele dia), cortou a língua de Feliciano (a única testemunha) para que, dessa forma, não pudesse mais falar e contar o que realmente aconteceu. Era muito cruel e sádico com os homens e mulheres escravizados que trabalhavam em suas propriedades, e representa a classe dominante dos senhores de terras do século XIX. Como o recorte cronológico deste livro é longo, vai de 1647 a 1977 , esta história (as duas versões) é recontada na voz do cego Faustino tempos depois, em 1896.

O personagem Perilo Ambrósio simboliza o mito do herói da Independência, e é através da dupla narrativa, contada na obra e recontada na voz do personagem Faustino, que João Ubaldo Ribeiro desconstrói esse mito sobre heróis da história. Na voz de Faustino é questionada a construção de uma memória oficial e também da história, apresentando a ideia que podem existir outras versões que forneçam destaque a outros personagens e outras vozes. De acordo com Rita Olivieri-Godet, esse questionamento apresentado na obra configura uma "crítica ao uso da história, ao uso privativo que dela se faz, em função de interesses de grupos, colocando a nu a maneira como o Estado e as classes dominantes apropriam-se dos fatos para legitimarem-se no poder."452

A obra de João Ubaldo é profusa de questionamentos e o modo como construiu o desenvolvimento do personagem Perilo Ambrósio, sua história na trama e o modo como é recontada na voz de Faustino, funciona como uma provocação ao leitor. Embora alçado à categoria de herói da Independência e da Bahia, Perilo Ambrósio era manipulador e oportunista. Acompanhamos na obra que por trás de uma "máscara" de um homem ilustre, o Barão de Pirapuama era um homem perverso, sádico, violento, que não possuía as virtudes que fingia socialmente. A partir disso, a provocação leva ou pode levar o leitor a refletir sobre a construção de memórias oficiais e personagens históricos. O interessante, é que o autor não utilizou nenhum personagem histórico para projetar essa reflexão, ele criou e inseriu o seu personagem num momento histórico: as lutas da Independência na Bahia. Em oposição a essa história do Barão de Pirapuama como "falso" herói, na voz da professora encontramos o oposto quando se refere a D. Pedro II e outros homens da História. Dona Jesuína os descreve de modo altivo, próprio do período, a segunda metade do século XIX.

${ }^{452}$ Rita OLIVIERI-GODET, "Viva o Povo Brasileiro: a ficção de uma nação plural”. In: Viva o povo Brasileiro: a ficção de uma nação plural. São Paulo: É Realizações Editora, 2014, p.80. 
Em mais uma passagem, um dos pontos que o romance exalta: os muitos heróis anônimos, estes dispersos na narrativa em batalhas, lutas que fazem parte da história do Brasil, como a Guerra de Canudos ${ }^{453}(1896$ - 1897) ou a Guerra do Paraguai (1864 1870), por exemplo, e as lutas diárias do povo, daqueles que compõem o grupo de subalternos no Brasil. Na cena, soldados e homens retornados da Guerra do Paraguai receberiam honras em uma cerimônia. Foi solicitado que Zé Popó (um dos retornados) fizesse um discurso. Após longa missiva sobre a guerra, narra como se respondesse a uma pergunta, sobre ter presenciado grandes atos de heroísmo como se falava desde o início da Campanha:

Tinha, sim, tinha visto muitos atos de valentia e coragem em ambos os lados. Mas gostaria de dizer que não se podia esquecer que eram heróis todos os que suportaram o medo, a doença, a fome, o cansaço, a lama, os piolhos, as moscas, os percevejos, os carrapatos, as mutucas, o frio, a desesperança, a dor, a indiferença, a lama, a injustiça, a mutilação. Eram todos heróis e não nasceram heróis, eram gente do povo, gente como a gente da ilha e da Bahia, que também suportava muitas dessas coisas e mais outras, até piores, sem ir à guerra nem ser chamada de heroica. ${ }^{454}$ (grifos meus)

O discurso provoca um efeito interessante com a descrição do que era suportado. Como a frase é longa, vai produzindo uma sensação de pesar e constância na leitura. As palavras grifadas podem perfeitamente ser articuladas a uma rotina de sobrevivência dentro e fora de uma situação de guerra. O personagem finaliza falando dos heróis da vida diária, dos que lutam sem ir à guerra e não recebem qualquer reconhecimento por isso, devido uma normalização de sua situação de vida. É interessante inclusive a mutilação, que se direciona automaticamente à ligação com a guerra, entretanto, é possível resgatar o que ocorreu com Feliciano, o cativo que teve sua língua cortada para não revelar o segredo da farsa do Barão de Pirapuama.

A descrição dos heróis da história e de D. Pedro II feita pela professora de Dafé, produz o efeito de oposição, se observarmos de forma alternativa a história do herói da Independência na Bahia, o Barão de Pirapuama. A fala da professora representa a voz de

\footnotetext{
${ }^{453}$ Uma referência sobre a Guerra de Canudos é: Euclides da CUNHA, Os Sertões: campanha de Canudos. Edição crítica e organização Walnice Nogueira GALVÃO. São Paulo: Ubu Editora : Edições SESC São Paulo, 2016; originalmente publicado em 1902; e Euclides da CUNHA, Canudos: diário de uma expedição. São Paulo: Martin Claret, 2013.

${ }^{454}$ João Ubaldo RIBEIRO, op.cit., p.476.
} 
alguém que ensina, tal qual aprendeu, em um ambiente de aprendizagem formal, uma escola. Em contraposição, na voz do contador de histórias, o cego Faustino, temos o questionamento sobre o reconhecimento de heróis da história. Isso ocorre através da história da vida de Perilo Ambrósio e o testemunho de Feliciano sobre o assassinato de Inocêncio para simular ferimento em uma batalha que Perilo Ambrósio não lutou. O relato e provocações são feitos em outro ambiente, de cultura popular e transmissão de história oral. Por fim, retoma-se o tema do reconhecimento dos muitos heróis anônimos da vida e de guerra, estes que são o povo que aguentam tantas ou piores tribulações que combatentes em guerra. A direção da narrativa aponta para a luta diária dos heróis anônimos do povo.

O papel do leitor e seu repertório na leitura de Viva o povo brasileiro é importante, pois as provocações como foram apresentadas podem ser repercutidas na mente do leitor estimulando reflexões e inquietações sobre a trama e uma projeção para a história do Brasil. Mas dependendo da leitura feita e do repertório do leitor, essas questões podem passar despercebidas, pois o autor criou personagens fictícios para levantar algumas questões, tais quais as aqui analisadas.

Pensando em obras que podem possuir um engajamento histórico e político maior, e refletindo sobre as provocações como as encontradas em Viva o povo brasileiro, de João Ubaldo Ribeiro, é significativo destacar o momento de publicação, 1984, período de abertura política no Brasil. Após a Ditadura militar que vigorou no Brasil de 1964 a 1985, em que muitos direitos civis e políticos foram suprimidos e violados, parece natural uma evocação de lutas do povo contra uma classe de mando no Brasil. Todavia, Julio Pimentel aponta que "uma aproximação atenta à ideia de escrita como articulação de múltiplos e alheios engenhos permite enxergar a centralidade do autor, de sua inserção num dado tempo e num certo espaço." 455 Isso "não significa que o autor seja alguém determinado pelo tempo em que vive, cuja biografia ou cujas opções políticas e assemelhadas definem o que faz. Mas alguém que é capaz de, a pelo ou contrapelo, dialogar com paisagens do presente e do passado. ${ }^{456}$ No caso de João Ubaldo, parece ter ocorrido este movimento, pois aborda o heroísmo dos anônimos, do povo, dos subalternos em oposição a um grupo dominante, trazendo esse conflito no enredo do livro, desde a ocupação do território brasileiro se estendendo até a ditadura. Algumas das outras obras literárias da mesma

\footnotetext{
455 Júlio Pinto PIMENTEL, op.cit., p.12-13.
}

${ }^{456}$ Ibidem, p. 12-13. 
forma parecem seguir nessa direção, e dialogam com o presente da publicação e o passado, com projeções para o futuro.

Em síntese, foi possível perceber uma permanência de características semelhantes na descrição dos personagens da Família Real e tratamento dispensado a eles nas obras literárias. Chama atenção o dado da cultura brasileira que satiriza esses personagens. Aspecto que se mostrou característico também da cultura de história brasileira. Se a historiografia avança em sentidos variados, com pesquisas que tratem de forma diversificada os sujeitos que participaram do processo de Independência, parece que permanecem representações já muito consagradas na literatura.

Portanto, é possível perceber que a história, a historiografia e a literatura se entrecruzam de forma a compor um imaginário social e uma cultura de história, projetando, dessa forma, representações da Independência. Evidenciam-se, entre outras, duas linhas majoritárias: uma elevada, e outra para rebaixar a primeira, cômica. ${ }^{457}$ Neste caso, embora possuindo trabalhos mais recentes de forma a construir uma visão alternativa a alguns destes personagens, os registros do século XIX, que foram amplamente estudados e desenvolvidos em pesquisas historiográficas posteriormente, ainda permanecem preponderantes, sobretudo as descrições feitas na obra de Oliveira Lima. ${ }^{458}$ Essas obras literárias demonstram a reafirmação de uma imagem negativa elaborada no século XIX, sobre Carlota Joaquina e também sobre D. João, embora para o último, tenha sido feito um esforço de abrandamento exaltando suas possíveis qualidades morais e de personalidade. Sobre D. Pedro, temos duas abordagens: uma que evidencia sua atuação política e destaca suas ações e estratégias como estadista, sobretudo nos poemas épicos, e outra versão, em geral encontrada nos romances, que explora sua vida privada, sua fama de "mulherengo" e seus casos extraconjugais. ${ }^{459}$ Nestas obras

\footnotetext{
${ }^{457}$ Como já havia sido apontado em João Paulo PIMENTA [et.al.], op.cit., 2014.

458 Manuel de Oliveira LIMA, op.cit., 1908.

${ }^{459}$ Além das produções literárias, tornou-se popular uma gama de romances históricos ou livros produzidos por não-historiadores sobre a história do Brasil e da Independência, que ganharam amplo mercado consumidor, e privilegiam a vida privada destes personagens. Cito como exemplo, as obras de Paulo Setúbal, ou Laurentino Gomes, dentre outras. Laurentino GOMES. 1808: como uma rainha louca, um príncipe medroso e uma corte corrupta enganaram Napoleão e mudaram a história de Portugal e do Brasil. São Paulo: Editora Planeta do Brasil, 2007; Laurentino GOMES. 1822: como um homem sábio, uma princesa triste e um escocês louco por dinheiro ajudaram Dom Pedro a criar o Brasil. São Paulo: Globo, 2015. Paulo SETÚBAL. As maluquices do Imperador (1808- 1834). São Paulo: Geração Editorial, 2008; Paulo SETÚBAL. A Marquesa de Santos (1813-1829). São Paulo: geração editorial, 2009. As obras de Paulo Setúbal por exemplo, foram usadas para a elaboração da minissérie televisiva "Quintos dos Infernos", que foi analisada no artigo: João Paulo PIMENTA [et.al], "A Independência e uma cultura de história no Brasil”..., op.cit.,2014. Este conjunto de obras, que não compõe o corpus analisado nesta dissertação, mas foi analisado no artigo citado, também reafirma certas projeções e representações destes personagens como as encontradas nas obras aqui analisadas.
} 
literárias encontramos a construção de imagens que reiteram certos clichês, estereótipos e caricaturas dos personagens históricos aqui tratados, e que fazem parte de um imaginário social e dessa cultura de história.

Como um balanço do conjunto das obras, é possível afirmar que parte daquelas produzidas ainda no século XIX tendiam a seguir e consolidar a memória em torno de uma história da Independência tida como oficial com protagonismo nos personagens da Família Real. A partir do século XX, surgem outras narrativas questionando essa versão e mesmo a construção desse tratamento heróico. A história cômica também segue nessa direção de desconstrução de um tom elevado destes personagens. Por esse motivo, se incorporam dados sem relevância para o processo de Independência, como o suposto malestar de D. Pedro, ou dados da vida pessoal dos monarcas (o que, sem dúvida, atende a uma demanda dos leitores). São elementos com uma função de rebaixamento e afastamento de uma construção nobre da história e dos personagens.

Há ainda um resgate da história da revolução de Pernambuco de 1817 pelos romances A noiva da revolução (2006) e Olhos Negros (2009). Ambas as obras dialogam diretamente com a historiografia. Identifica-se uma pretensão clara de instrução e didatismo, que indica uma preocupação com uma possível marginalização ou obliteração da Revolução de Pernambuco de 1817 na memória nacional. Alguns artigos ${ }^{460}$ e estudos apontam que essa preocupação possui fundamento e que há um destaque maior, por exemplo, à Inconfidência Mineira (1789) na historiografia, o que poderia indicar uma possível "interdição" da Revolução Pernambucana em estudos historiográficos. Assim, a publicação dos romances sobre a revolução de Pernambuco, com características tão semelhantes, parecem indícios de que há a percepção desse ofuscamento da história e existe um esforço para evidenciar a importância da revolução na história nacional, no período joanino e no processo de Independência do Brasil. Ao mesmo tempo, a publicação de dois romances sobre a revolução de Pernambuco de 1817 chama atenção para uma possível "interdição" de sua história e revela uma tentativa de um movimento de recuperação dessa história e memória. Ademais, esses movimentos demonstram como ocorrem as mudanças na cultura de história brasileira.

\footnotetext{
${ }^{460}$ Tratam-se dos artigos de: Thamara de Oliveira RODRIGUES, “A revolução Pernambucana e as disputas historiográficas: Abreu e Lima e Francisco Adolfo de Varnhagen”. In: História e Cultura, Franca, v.6, n.1, p.289-308, mar.2017. E: Mariana dos Santos RIBEIRO, "Frei Caneca e a Confederação do Equador". In: Revista Intellèctus, v.5, n.2, 2006, p.3. Sobre a questão a última autora indica também: José Murilo de CARVALHO, "Tiradentes: um herói para a República". In: A formação das almas: o imaginário da República no Brasil. São Paulo: Cia das Letras, 1990.
} 


\section{Capítulo 3. O Brasil e os brasileiros: Imagens de um caleidoscópio}

De maneira distinta dos anteriores, este capítulo configura-se de modo plural, ou seja, serão apresentadas análises de temas variados. Começamos pelas representações das identidades políticas nas obras literárias, e acompanhando o primeiro item, o seguinte apresenta imagens e visões do Brasil e dos brasileiros que configuram estereótipos ainda atuais. No terceiro tópico, discorremos sobre costumes e festas populares que já vigoravam no século XIX, se tornando muito tradicionais no Brasil e foram representados de maneira muito semelhante entre as obras examinadas. $\mathrm{O}$ quarto item apresenta a análise de ideias e projetos de Brasil, ou seja, o que se delineava no horizonte de expectativa de acordo com cada grupo social a partir da Independência. No quinto e último tópico, analisamos concepções de História, questionamentos sobre sua escrita e ampliamos o estudo para a memória da Independência do Brasil.

\subsection{Identidades políticas no Brasil do século XIX}

Atualmente já é tema esclarecido na historiografia que havia múltiplas identidades políticas no Brasil no período da Independência. ${ }^{461}$ E se hoje não há dúvidas quanto ao uso do termo "brasileiro(s)" quando se faz menção sobre os sujeitos ou cidadãos que nasceram no Brasil, no que se refere a produção de textos literários que abordam a primeira metade do século XIX, como esse aspecto aparece?

Algumas obras literárias trabalharam essa dimensão observando as várias nuances que se manifestavam no Brasil da primeira metade do século XIX. Assim, encontramos menções a brasileiros, a portugueses, aos bahienses, aos pernambucanos, paulistas, entre outras, de forma a iluminar a questão das identidades políticas coletivas.

Em Paraguassú (1835 e 1837), epopeia de Ladislau dos Santos Titara, é muito interessante a construção narrativa e poética. Não foram elaborados versos descritivos a respeito das identidades políticas na Bahia e no Brasil. Apenas citando o apoio que

\footnotetext{
${ }^{461}$ István JANCSÓ \& João Paulo PIMENTA, "Peças de um mosaico ou apontamentos para o estudo da emergência da identidade nacional brasileira". In: Revista de História das Ideias, vol.21, 2000, Instituto de História e Teoria das Ideias. Faculdade de Letras da Universidade de Coimbra, p.389-440. Neste artigo os autores explicam que embora haja uma projeção apenas numa dicotomia portugueses versus brasileiros, $o$ Estado brasileiro se formou em meio a coexistência de múltiplas identidades políticas "cada qual expressando trajetórias coletivas que, reconhecendo-se particulares, balizavam alternativas de futuro". (p.392).
} 
recebiam de tropas, o poeta menciona uma pluralidade de identidades políticas. Assim encontramos: os lusitanos ou lusos; os brasileiros; os baianos e bahienses ${ }^{462}$, os jacuipenses ${ }^{463}$, olindanos ${ }^{464}$; sergipenses e também putuipebanos ${ }^{465}$; os macahenses ${ }^{466}$; também os fluminenses ${ }^{467}$, entre outras. E claro, há o destaque da luta dos brasileiros ${ }^{468}$ contra os lusitanos, ou seja, há uma ênfase na situação emergente, a luta para expulsão das tropas de Portugal ${ }^{469}$ da Bahia. István Jancsó e João Paulo Pimenta ressaltam que as variações das identidades políticas também se referiam a uma distinção não apenas regional, mas entre os portugueses da América e os da Europa, entre os portugueses da Bahia dos portugueses paulistas, no período colonial, além dos "naturais da terra" ${ }^{470}$ Embora, Jancsó e Pimenta argumentem que no período não se tratasse apenas de uma oposição entre brasileiros contra portugueses, na epopeia Paraguassú (1835 e 1837) que possui enredo baseado no momento da luta da Independência na Bahia, era esperado apontar o outro, o inimigo, destacando a diferença fundamental: os lusos ou lusitanos versus os brasileiros ou baihienses, ou tropas libertadoras.

No épico de Titara, encontramos bons exemplos da diversidade de identidades políticas existentes no período, assim como Jancsó e Pimenta demonstraram. As referências regionais possuem contornos claros e variados ressaltando as regiões, fossem as internas do Recôncavo Baiano, fossem as de outras províncias. Há também referências aos povos indígenas: Tupinambás ${ }^{471}$, Tamoyos ${ }^{472}$, Cayrirys $^{473}$, Tapajós ${ }^{474}$. Essa é uma das poucas obras literárias no corpus dessa dissertação que menciona os povos nativos do Brasil. ${ }^{475}$ Há que se ressaltar mais uma vez, que essa obra foi escrita por um

\footnotetext{
${ }^{462}$ Ladislau dos Santos TITARA, op.cit, p.254.

${ }^{463}$ Ibidem, p.72. Em nota o autor esclarece que Jacuipenses são os baianos "assim chamados do Rio Jacuipe".

464 Ibidem, p. 143.

${ }^{465}$ Ibidem, p.89. Ver nota 3 na referida página, putuipebanos se refere aos de Sergipe também.

${ }^{466}$ Ibidem, p.85. Na nota da referida página o autor esclarece que são os naturais do Rio de Janeiro, em razão do Rio Macaé.

${ }^{467}$ Ladislau dos Santos TITARA, op.cit, p.79.

468 O autor utiliza a designação "brasileiros" e também as diversas designações por províncias como indicado. Ibidem, p.142 e p.305, por exemplo.

${ }^{469}$ Ladislau dos Santos Titara utiliza a designação de "Lusos", "lusitanos" ou "facção Lisboêz”, ou "hostes lusitanas", "Legião Lusitana". Ibidem, p.170, 171, 175, 142.

${ }^{470}$ István JANCSÓ \& João Paulo PIMENTA, op.cit, 2000, p.398.

${ }^{471}$ Ladislau dos Santos TITARA, op.cit., p. 227.

472 Ibidem, p.228.

473 Ibidem, p. 223.

${ }^{474}$ Ibidem, p. 178.

475 Outra obra que cita ou faz referência às raízes dos povos nativos do Brasil, é Viva o povo brasileiro de João Ubaldo Ribeiro. Obra cuja maior parte do enredo também se passa na Bahia, na região do Recôncavo Baiano. Os personagens centrais dos dois capítulos que se passam no século XVII (os capítulos do livro não possuem títulos) narram episódios com os povos nativos do Brasil. São personagens que retornam no
} 
contemporâneo dos eventos da Independência. O autor, Ladislau dos Santos Titara, participou das tropas baienses, lutando contra as tropas dos partidários à manutenção do vínculo com Portugal. Por esse motivo, essa diversidade de identidades políticas e designações é condizente ao período, demonstrando de forma exemplar um "mosaico" de identidades políticas, como demonstrado por Jancsó e Pimenta.

Em Viva o povo brasileiro (1984), as nuances identitárias são trabalhadas com o personagem Perilo Ambrósio, e emerge não apenas a distinção de nascença mas de consideração. Perilo Ambrósio era filho de portugueses, nascera em Portugal, assim como seus pais e irmãs, mas foi expulso de casa pelo pai. Contudo, na já referida farsa que arma em campo de batalha, quando encontra o comandante brasileiro e este lhe pergunta se Perilo Ambrósio é português, ele responde:

- Sim, meu comandante, foi Portugal onde primeiro vi a luz e entre portugueses fui criado, pois que o são meu pai e minha mãe, como hão de ser também os vossos maiores. Mas, se lá vi a luz, cá no Brasil foi que vi a vida... Meu pai, sim, muito infelizmente se alia à causa do opressor e isto me parte o coração, sendo eu brasileiro mais que por presença aqui, senão porque me sinto tão nativo a estas terras quanto as árvores e os bosques. ${ }^{476}$

Que não se iluda o leitor, pois a fala é tão falsa quanto seu heroísmo. Momentos antes o narrador esclarecia: "Se queria que os brasileiros prevalecessem, não era por ser brasileiro - e na verdade se considerava português -, mas expulso de casa, abominado

enredo ao longo do livro através de memórias e religiosidade. Além desses capítulos, em passagem em que o narrador explica a recompensa de Perilo Ambrósio, recebendo o título de Barão, quando menciona Pirapuama que significa baleia e faz referência também a parte dos negócios que o Barão de Pirapuama (o Barão das baleias) viria a ter, acrescenta: "Pirapuama, nome que afirmava a singularidade nacional, que proclamava orgulhoso sua origem austral, atada àquelas terras e a seus habitantes originais, os nobres selvagens de antanho." In: João Ubaldo RIBEIRO, op.cit., p.47 e 48. Em Primícias de Joaquim Gil Pinheiro, o canto I "Dos indígenas nas selvas do Brasil"; canto II "Diferença que havia entre as duas grandes raças beligerantes: Tapuya e Tupy"; canto III "Crenças religiosas dos Tupys"; canto IV "Solenidades religiosas dos Tupys", canto V "Das festas religiosas e homicidas do Cauim"; canto VI "Dos usos, costumes e artes dos Tupys", o canto VII também possui menções aos povos indígenas mas já trata dos primeiros contatos dos portugueses com o Brasil, o capítulo é intitulado "Da descoberta do Brasil por Pedro Alvares Cabral". Assim como em Paraguassú de Ladislau dos Santos Titara, Primícias, utiliza muitas palavras de origem indígena que são explicadas em nota no poema. Porém esses cantos do I ao VI são especificamente dedicados aos povos originários do Brasil e seus costumes, narrados poeticamente pela visão do autor português que pretende com a obra louvar os grandes feitos portugueses. In: Joaquim Gil PINHEIRO, op.cit., 1900. No épico de Teixeira e Sousa, Independência do Brasil em XII Cantos, no canto VIII há trecho que o velho Thomé, capitão-mór indígena acompanha D. Pedro em viagem, e ele lhe pede para contar uma história antiga do Brasil. O velho Thomé narra a história de Ramalho e Antônio Rodrigues; episódio de Tebyreçá (sic), Piquenrobin, Çoboaçu (sic.), Itabira e seus filhos. São histórias dos povos indígenas. In: Antonio Gonsalves TEIXEIRA e SOUSA, op.cit., Tomo II, 1855.

${ }^{476}$ João Ubaldo RIBEIRO, op.cit., p.42. 
pelos pais e por todos os parentes, sob ameaça de deserdação, deliberara adquirir fama de combatente ao lado dos revoltosos. ${ }^{" 477}$ No caso do personagem o pertencimento variava conforme seus interesses, era dissimulado e oportunista. Entretanto, a sua origem e comportamento iluminam um pouco o complexo aspecto de identidades do período.

Em outra passagem, o narrador descreve sobre como Perilo Ambrósio entrou para o ramo comercial através do trapiche do sogro, o "português brasileiro, Afonso Soares Matinho de Almeida" ${ }^{478}$ (grifos meus). Aqui já se delineia de forma mais clara, que se trata do português da América. Portanto, em Viva o povo brasileiro, essa identidade de nascença e consideração parece convergir com as delicadas nuances que se delineavam no período colonial, conforme apontaram Jancsó e Pimenta ${ }^{479}$.

No romance Olhos Negros (2009), além dos já referidos temas do revolucionário pernambucano e da província enquanto pátria ${ }^{480}$, há ainda uma outra abordagem sobre identidades. Essa outra visão ressalta um antagonismo entre portugueses versus brasileiros, como se vê no diálogo entre Maricotinha e Muniz Tavares:

Monsenhor me explicou que o povo brasileiro ainda não estava constituído. Que pouquíssimos tomavam consciência dessas questões. Havia o sentimento de pertencer a uma nacionalidade quando diante de inimigo estrangeiro. Mas não diante de Portugal, sempre visto como nossa pátria-mãe. Estavam acostumados a ser considerados portugueses. Que, apegados à ideia da monarquia, os brasileiros preferiam temer a um rei longínquo e imaginário a um irmão conhecido e próximo. ${ }^{481}$

Em linguagem coloquial, a narradora explica que a identidade do "brasileiro" ainda não estava formada, e ressalta o sentimento de pertencimento a uma "comunidade imaginada" 482 apenas quando diante de inimigo estrangeiro. A menção à "pátria-mãe" coloca os dois lados do Reino português em patamar de irmandade. Interessante que se apresente essa questão da identidade no Brasil, embora fique no plano de portugueses e

\footnotetext{
${ }^{477}$ Ibidem, p.40.

478 Ibidem, p.72.

${ }^{479}$ István JANCSÓ \& João Paulo PIMENTA, op.cit, 2000, p.398.

${ }^{480}$ A análise da questão encontra-se no capítulo 1, na parte em que foram examinados os conceitos "pátria" e "nação", onde há outro exemplo a um pertencimento apontando as nuances provinciais e mesmo de regiões dentro da província, consideradas como pátria.

${ }^{481}$ Maria Cristina Cavalcanti de ALBUQUERQUE. Olhos Negros - O romance de 1817.., op.cit, 2017, p. 236.

${ }^{482}$ Benedict ANDERSON, Comunidades Imaginadas: reflexões sobre a origem e adifusão do nacionalismo. São Paulo: Companhia das Letras, p.2008.
} 
brasileiros, não se fala sobre o português do reino, o português americano e os nascidos no Brasil. Muito menos há referências em termos de um mosaico de identidades políticas, de múltiplas identidades regionais (os paulistas, os mineiros, etc. ${ }^{483}$. Somente a identidade pernambucana era ressaltada em A noiva da revolução (2006) e Olhos Negros (2009), e utilizada de maneira retórica e ideológica para construção de unidade, era a pátria pernambucana contra o rei português.

No romance de Paulo Santos de Oliveira, A noiva da revolução (2006), as identidades em Pernambuco de 1817 também são abordadas, mas a partir da oposição entre brasileiros e portugueses. Na narrativa, a partir das anotações de Domingos José Martins ele se pergunta:

O que faríamos com os portugueses? (...) Deveríamos tratá-los como irmãos ou despachá-los rapidamente? (...) a decisão veio logo. Muitos brasileiros carregavam séculos de ódio reprimido contra os galegos. Vozes exaltadas pediam expulsão e confisco dos seus bens. Alguns queriam até exterminá-los. Mas nós, do provisório, aspiramos a paz. (... $)^{484}$

A mesma questão que emerge do excerto de Olhos Negros (2009), aparece aqui: brasileiros (pernambucanos) e portugueses faziam parte do mesmo Reino, deveriam ser tratados como "irmãos" ou inimigos? Destaca-se o sentimento de "ódio" aos portugueses principalmente em função da situação que Pernambuco enfrentava, por cobranças de muitos impostos, recrutamento forçado, insatisfações que se acumularam pela política do monarca.

Entretanto, nos dois romances sobre a revolução de Pernambuco é utilizada de maneira ostensiva a referência a "brasileiros" e "portugueses", designações que em 1817 não eram empregadas. De toda forma, é possível perceber através das obras que havia sutilezas e disputas subentendidas no tratamento de identidades políticas no período.

\subsection{Imagens dos brasileiros: estereótipos de longa duração}

Para além de identidades de pertencimento, há uma identidade que faz parte de uma imagem e auto-imagem dos brasileiros, que compõe um senso comum do famoso

\footnotetext{
${ }^{483}$ István JANCSÓ \& João Paulo PIMENTA, op.cit., 2000.

${ }^{484}$ Paulo Santos de OLIVEIRA, op.cit., p.103.
} 
“jeitinho brasileiro", o "festeiro", o "malandro", o povo "bom anfitrião", etc. Muitas dessas "imagens" dos brasileiros foram construídas ainda no Brasil colônia, a partir dos relatos dos viajantes que depois eram publicados na Europa. Como mostrou Elis Pacífico ${ }^{485}$, essa visão parte de um olhar de superioridade dos que se consideravam representandes da civilização, sobre o que consideravam exótico aqui no Brasil, por ser diferente de seus costumes que eram sua referência. Chama atenção que, se inicialmente essa foi uma construção a partir do olhar de estrangeiros, acabou sendo incorporada pelos próprios brasileiros atravessando séculos, e muitas dessas imagens permanecem até os dias atuais como parte de uma identidade brasileira.

Assim, foram encontradas referências sobre o Brasil e os brasileiros, revelando/ilustrando essa visão e senso comum, que nada mais é que um constructo em torno da imagem do país e seu povo.

Ao contrário do que se pode imaginar - que tais concepções foram encontradas somente nas obras do século XX em diante - na epopeia de Teixeira e Sousa (1845 e 1855) o poeta dedica alguns versos para descrever o caráter dos brasileiros:

É em geral o povo Brasileiro/ Polido, delicado, e talentoso;/ A isto acresce o dom de hospitaleiro,/ Franco, discreto, nobre e generoso;/ Fido. prudente, grato, e verdadeiro;/ Nos perigos maiores valoroso;/ Da cruel opressão sempre inimigo;/ Da Pátria, e de seus reis fiel amigo. ${ }^{486}$

- Religioso em seu cristianismo/ Sente o sagrado amor da humanidade;/ Ardente em seu leal patriotismo/ Do coração detesta a crueldade;/ Infenso sempre ao torvo despotismo,/ Adora reverente a Liberdade;/ Pois não pôde sofrer jugo tirano/ O generoso peito americano! ${ }^{487}$

Seria anacrônico apontar a contradição entre uma imagem do povo que "detesta a crueldade e despotismo", "inimigo da opressão" (lembrando que muitas das expressões que faziam analogia ao "despotismo de Portugal" remetiam a referências à escravidão) e que mantinha a escravidão e pregava a liberdade na retórica pela Independência. De acordo com os valores da época, não apenas da Independência mas da publicação da epopeia, isso não parecia paradoxal. Entretanto, algumas noções sobre os brasileiros já se

\footnotetext{
${ }^{485}$ Elis PACÍFICO, A construção de uma identidade nacional brasileira em visões estrangeiras (18081822). Dissertação de Mestrado. Faculdade de Filosofia, Letras e Ciências Humanas (USP). São Paulo, 2015.

${ }^{486}$ Antonio Gonsalves TEIXEIRA E SOUSA, op.cit, Tomo I, p.135.

${ }^{487}$ Ibidem, p. 136.
} 
apresentam: o povo polido; delicado; hospitaleiro; franco; generoso; fiel, grato e religioso. Essa adjetivação já norteia aspectos que compõem um senso comum, uma imagem sobre os brasileiros permanente ainda no século XXI, em visões de estrangeiros e do próprio país. Além disso, já que foram apontados os aspectos de uma contradição (anacrônica) entre defesa da liberdade e horror à opressão, crueldade e despostismo e a manutenção do regime escravista, adentraremos no plano da cordialidade no Brasil. Sérgio Buarque de Holanda ao descrever o "homem cordial" utiliza descrição semelhante a de Teixeira e Sousa em sua epopeia Independência do Brasil (1847 e 1855). Assim aponta Sérgio Buarque: "A lhaneza no trato, a hospitalidade, a generosidade, virtudes tão gabadas por estrangeiros que nos visitam, representam, com efeito, um traço definido do caráter brasileiro..."488 (grifos meus) Ironicamente, Teixeira e Sousa aponta no "Argumento" do Canto III e fecha o terceiro verso da sequência anteriormente transcrita, que trata-se de louvar o caráter do brasileiro. Pois já em 1847, data da respectiva publicação da epopeia de Teixeira e Sousa, essa caracterização do brasileiro tal qual a feita por Ribeiro Couto e apontada por Sérgio Buarque do "homem cordial"489 encontrase fixada na literatura brasileira. Obviamente, fazemos a ressalva que o que é teorizado e criticado por Sérgio Buarque, é simplesmente a manifestação de imaginário social e construção poética na obra de Teixeira e Sousa. Manifestação de um senso comum em 1847 e 1931, por Teixeira e Sousa e Ribeiro Couto, respectivamente, a última levada a público e problematizada por Sérgio Buarque de Holanda.

No romance de Ruy Castro, Era no tempo do rei (2007), o menino Leonardo tipifica mais um estereótipo e uma ideia construídos à respeito do Brasil e dos brasileiros: "Leonardo preferia ser como o Brasil: vagabundo, alegre, virador, esperto, sensual - e de que importava o futuro se o presente era tão generoso?" ${ }^{490}$. Importante frisar que no período retratado (a história se passa entre 1808 e 1810), a identidade "brasileiro" não era definida, existiam muitas identidades em disputa no território, como analisado no item

\footnotetext{
${ }^{488}$ Sérgio Buarque de HOLANDA, “O homem cordial”. In: Raízes do Brasil, 26.ed. São Paulo: Companhia das Letras, 1995, p.146-147.

${ }^{489}$ Em seu livro, o próprio Sérgio Buarque explica que a expressão "homem cordial" foi extraída de carta de Ribeiro Couto. O embaixador brasileiro instalado em Belgrado, Ribeiro Couto enviou a carta ao embaixador do México no Brasil Alfonso Reyes, quando o último fundou a revista Monterrey: Correo Literario de Alfonso Reyes. A carta em questão é datada de 07 de março de 1931, e foi publicada na seção "Epistolário" da edição de março de 1932, com o título: "El Hombre Cordial, producto americano". Duas décadas depois Ribeiro escreveu a Reyes solicitando uma cópia da carta sobre o "homem cordial". A última carta com a cópia podem ser encontradas no arquivo digital do Instituto Moreira Salles, de onde estas informações foram retiradas. Consulta em 08/07/2019. Site: https://www.correioims.com.br/carta/origemdo-conceito-de-homem-cordial/

${ }^{490}$ Ruy CASTRO, op.cit, p. 39.
} 
anterior. ${ }^{491}$ E também é importante esclarecer que essa visão do brasileiro existiu ao longo de boa parte do século XIX e perdura até os dias atuais, sendo reelaborada ao longo do tempo. Elis Pacífico destaca que a relação de identidade e alteridade teve um papel importante "na medida em que a criação de juízos e conceitos realizada pelos viajantes teve algum poder prático no processo de formação nacional do Brasil." ${ }^{\text {492 }}$

Pimenta [et.al.], citando José Manuel Sobral, historiador dedicado ao estudo da identidade nacional portuguesa, esclarece sobre estes estereótipos atribuídos a grupos nacionais:

esse tipo de caracterizações genéricas, de lugares-comuns sem fundamento, ou que constituem generalizações abusivas a partir de fatos pontuais, são, no entanto, importantes, porque assinalam diferenças que se julga existirem entre as nações. São um testemunho da existência destas, pois todos os grupos nacionais possuem estereótipos sobre si próprios e sobre os outros, que são inerentes à própria construção de uma identidade ${ }^{493}$

Em Viva o povo brasileiro (1984), encontramos a projeção de uma imagem do povo de forma pejorativa pronunciada na voz do cônego D. Francisco Manoel de Araújo Marques, amigo do Barão de Pirapuama, em 1827. No trecho o cônego comentava sobre a vinda da Missão Francesa ${ }^{494}$ para o Brasil, para "divulgar impropriamente as belas-artes como se aqui tivéssemos um povo igual ao francês e não súcia de frascalhos, pirangueiros, servos rudíssimos, um povo feiíssimo, malcheiroso, mal-educado, ruidoso, estólido, preguiçoso, indolente e mentiroso" ${ }^{495}$ Esse é um olhar de alguém que se julga acima do povo, que não compõe esse coletivo singular, o povo brasileiro. Esse olhar do cônego enxerga o povo como réles, desprezível, tolo, indolente. Não bastando os adjetivos

\footnotetext{
${ }^{491}$ István JANCSÓ \& João Paulo Garrido PIMENTA, op.cit, 2000.

${ }^{492}$ Elis PACÍFICO, op.cit., p.134.

493 João Paulo PIMENTA [et.al.], op.cit., 2014, p.7

${ }^{494}$ A chamada Missão Francesa de 1816 consiste na vinda de um grupo de artistas da França para o Brasil a fim de projetar uma cultura artística nos moldes franceses, embelezar a cidade inclusive no plano arquitetônico, assim como pensar num plano de higienização urbana. A Missão resultou na fundação da Academia Imperial de Belas-Artes do Rio de Janeiro, em 1826. Anderson Ricardo Trevisan, aponta que há uma discussão na historiografia sobre a missão ter vindo para o Brasil a convite da Corte, ou se foi uma expedição francesa por iniciativa dos próprios artistas. O autor indica que o termo "Missão" foi cunhado por Afonso de Taunay. Em: Anderson Ricardo TREVISAN, "Debret e a Missão Artística Francesa de 1816: aspectos da constituição da arte acadêmica no Brasil.’'In: Plural, v.14, p. 9-32, Dez/2007. Sobre a Missão Francesa: Afonso Escragnole de TAUNAY, A Missão Artística de 1816. Brasília: Editora Universidade de Brasília, 1983; Elaine DIAS, "Correspondências entre Joachim Le Breton e a corte portuguesa na Europa: o nascimento da Missão Artística de 1816". Anais do Museu Paulista, São Paulo , v. 14, n. 2, p. 301313, Dec. 2006; Mário BARATA. "Manuscrito inédito de Lebreton. Sobre o estabelecimento de dupla escola de artes no Rio de Janeiro, em 1816". Revista do SPHAN, Rio de Janeiro, n. 14, p. 283-307, 1959. 495 João Ubaldo RIBEIRO, op.cit., p.135.
} 
depreciativos são atacados aspectos físicos também, o cônego chama o povo de feio e malcheiroso. Para esse personagem, a civilização é representada por brancos, pela Europa e o povo europeu. A visão projetada no romance também era uma imagem que muitos viajantes europeus tinham sobre o Brasil, e evidencia também a questão racial. A obra de João Ubaldo apresenta esse olhar através do personagem, que é um olhar de superioridade. Assim, o movimento que se produz de uma forma não intencional é a perpetuação de uma imagem no tempo, mais um tratamento pejorativo que se conecta com uma "identidade" do brasileiro, orientada pela formação do Brasil e um olhar de estrangeiros sobre o Brasil Colônia.

Voltando ao romance, o personagem que expressa essa visão em 1827 corresponde a esse tipo de concepção do olhar dos viajantes. É o olhar do outro sobre o brasileiro. No romance, é o olhar de uma classe dominante, expressa na voz do cônego e uma outra visão dos brasileiros, além das acima destacadas.

Assim, o caminho de perpetuação em uma cultura de história corresponde a um olhar construído e projetado por viajantes nos séculos XVIII e XIX que resiste ao tempo, e aparece em uma obra literária do século XX. Essas imagens dos brasileiros, vistas a partir da alteridade (a visão do outro), também se integraram a uma auto-referenciação e uma auto-imagem do(s) brasileiro(s). São imagens, clichês, estereótipos sobre o Brasil e os brasileiros que, em maior ou menor grau, ainda se fazem presentes em muitos contextos sociais dentro e fora do país.

\subsection{Costumes: ritos e celebrações populares}

Uma dimensão que foi mais explorada em algumas obras do que outras, é a caracterização de costumes do período Joanino. São descritos ritos, cortejos, Te Deums, entrudos, enfim, uma série de celebrações nas ruas que misturavam planos público e particular, como no caso das comemorações públicas de aniversários e casamentos da Família Real. As obras passam a impressão de que havia uma efervescência nas ruas em festas que ganhavam ampla adesão popular. As festas religiosas e comemorações da Família Real eram as mais celebradas. Uma referência para caracterização do Rio do Janeiro do período Joanino é a obra D. João VI no Brasil (1908), a mesma obra que também virou referência na caracterização dos personagens, como já abordado. Mas neste aspecto, há algo interessante, pelo menos dois romances que apresentam descrições desses costumes foram publicados antes da obra do historiador: Memórias de um sargento 
de milícias (1852 -1853) e Memórias Póstumas de Brás Cubas (1880). E encontramos descrições semelhantes.

No romance de Manuel Antônio de Almeida, Memórias de um sargento de milícias (1852-1853), é possível identificar alguns aspectos e valores representativos da sociedade do Rio de Janeiro do período Joanino: uma ideia de sucesso atribuída às pessoas que fossem estudar em Portugal, projeto idealizado pelo padrinho de Leonardo; pessoas que exerciam cargos públicos tinham uma posição de destaque e respeito social, como Leonardo Pataca (o pai do menino Leonardo). Há também um aspecto da vida pública e privada que se mesclavaa partir de celebrações e da presença da Família Real, como aniversários e casamentos. Eventos festivos que se tornavam públicos com participação popular no Rio de Janeiro. Essa efervescência de aspectos de costumes também é descrita no capítulo "O espetáculo das ruas" de D. João VI no Brasil ${ }^{496}$ : aparece o pitoresco, as festividades, o conjunto de tipos que compunham essa imagem da sociedade no período Joanino. Com a obra de Manuel Antônio de Almeida é possível acompanhar na literatura de forma mimetizada a caracterização do Rio de Janeiro da época. Memórias de um sargento de milícias (1852-1853) ficou conhecido como um romance de costumes por apresentar esta faceta dos tipos populares, das festividades, das crenças no Rio de Janeiro do período Joanino. Contudo, Antonio Candido analisando a obra alega que o realismo é contrabalanceado com elementos fabulosos. ${ }^{497}$ Mas Candido examina o romance em aspectos de documentário e documento que pode ser tomado do período Joanino ${ }^{498}$, e por isso, alerta para se considerar com reservas o romance como um "panorama documentário do Brasil joanino." ${ }^{499} \mathrm{O}$ autor lembra que o plano do "trabalho" foi suprimido da obra, sendo inclusive muito criticada por não apresentar a escravidão, parte fundamental da sociedade do período. A evidência ou existência do regime escravista aparece em passagens breves, apenas de forma anedótica. Segundo Cândido, o romance de Manuel

\footnotetext{
496 Manuel de Oliveira LIMA. "O Espetáculo das ruas”. In: D.João VI no Brasil. $3^{\text {a }}$ edição. Rio de Janeiro: Topbooks, 1996., p.593-622. A primeira edição da obra de Oliveira Lima foi lançada em 1908, portanto a obra de Manuel Antonio de Almeida é anterior à extensa pesquisa do período joanino feita e publicada por Oliveira Lima. De toda forma, as representações são correspondentes no romance e na obra de pesquisa histórica.

497 Antônio CANDIDO. "Dialética da malandragem". Revista do Instituto de Estudos Brasileiros, n.8, 1 jun. 1970, p.67 -89.

498 Antonio Candido examina e questiona se o romance pode ser considerado "documentário" do período joanino, ou seja, uma "reprodução fiel da sociedade em que a ação se desenvolve." A partir disso desenvolve uma discussão em torno do romance do tipo realista e do romance representativo. Em Ibidem, p.74-84.

${ }^{499}$ Antonio CANDIDO, op.cit., 1970, p.88.
} 
Antônio de Almeida talvez seja o único publicado no "século XIX que não exprime uma visão de classe dominante." 500

Embora concordemos com a análise de Candido, corroborando o romance Memórias de um sargento de milícias (1852 -1853) e a obra de D. Joaõ VI (1908) no Brasil, consideramos que a obra de Manuel Antônio de Almeida apresenta elementos que podem ser considerados, de forma mimética, representativos do Rio de Janeiro do período: os aspectos referentes às celebrações públicas e ritos. Segundo Antonio Candido, no romance de Almeida há "um realismo espontâneo e corriqueiro, mas baseado na intuição da dinâmica social do Brasil na primeira metade do século XIX. E nisto reside provavelmente o segredo da sua força e da sua projeção no tempo." 501

Citando alguns exemplos de Memórias de um sargento de milícias (1852-1853), temos o capítulo dedicado ao "Domingo do Espírito Santo": durante os nove dias que precediam o dia do Espírito Santo percorria na cidade uma encenação com meninos de 11 anos, vestidos a pastora formando um quadrado e ao centro ia um menino menor, o “imperador do Divino". O grupo de meninos era acompanhado de música e por uma "chusma de irmãos de opa levando bandeiras encarnadas e outros emblemas, os quais tiravam esmolas enquanto eles cantavam e tocavam." 502 As procissões nas ruas, denotam uma característica do Brasil, a forte religiosidade, momento em que as casas e as ruas recebiam ornamentos:

Nesse tempo as procissões eram multiplicadas, e cada qual buscava ser mais rica e ostentar maior luxo: as de quaresma eram de uma pompa extraordinária, especialmente quando el-rei se dignava acompanhá-las, obrigando toda a corte a fazer outro tanto: a que primava porém entre todas era a chamada procissão de ourives..$^{503}$

No romance que se liga diretamente ao de Manuel Antônio, Era no tempo do rei (2007), de Ruy Castro, também estão presentes os festejos de rua, seja o Carnaval (Entrudo), que aparece logo no início do livro, sejam as festas (como o noivado da filha de D. João, Maria Tereza com Pedro Carlos, regente da Espanha) que eram festejos da

\footnotetext{
500 Ibidem, p.87.

${ }^{501}$ Ibidem, p.72-73.

${ }^{502}$ Manuel Antonio de ALMEIDA, op. cit., p.120-121.

${ }^{503}$ Ibidem, p.108-111. A referida procissão de ourives é descrita, sendo a mais acompanhada devido os trajes que um cortejo de Baianas usava, deixando braços e pernas de fora.
} 
Corte mas se tornavam públicos, e da mesma forma possui semelhança com a já citada obra de Oliveira Lima. ${ }^{504}$

Em Era no tempo do rei (2007), vale a pena explorar uma passagem em que ficção e história se cruzam de uma maneira curiosa. No romance, em um episódio em que o narrador apresenta a trajetória de Vidigal, menciona que na festa de queima do Judas, no lugar do boneco do Judas malhava-se um boneco do Vidigal em vários cantos da cidade. ${ }^{505}$ Oliveira Lima, em D. João VI no Brasil (1908), aponta que após a chegada da corte, esta festividade (a queima do Judas) foi proibida para evitar a desordem. Porém, dias antes do embarque da Corte para Portugal, em 1821, o Intendente Geral da polícia ficou sabendo que "um magote compacto de arruaceiros enforcou e queimou em efígie a céu descoberto, em vez do Judas tradicional, alguns personagens conspícuos da administração, entre eles o próprio Intendente Geral e o comandante militar da polícia." Entrecruzamento entre ficção e história, e demonstração de como essas imagens construídas no romance e leituras relacionam-se com a cultura de história. Temos, dessa forma, um exemplo das caracterizações do Rio de Janeiro do século XIX em uma obra de literatura escrita em 2007, que produzirá em seus leitores ideias a respeito do período Joanino.

No romance de Machado de Assis, Memórias póstumas de Brás Cubas (1880), no episódio da comemoração pela primeira derrota de Napoleão ${ }^{507}$, em 1814 acompanhamos: “A população, cordialmente alegre, não regateou demonstrações de afeto à real família; houve iluminações, salvas, Te Deum, cortejo e aclamações." ${ }^{\circ 08}$ Pode ser considerado mero ornamento na narrativa, claro, mas também expressa costumes de época. Reforço este aspecto, pois ele emerge de forma muito constante nos romances, há uma mistura de uma dimensão pública e privada nestas celebrações, pois são fomentadas pela Corte com adesão popular. Essas festividades tornaram-se muito comuns a partir da vinda da Corte para o Rio de Janeiro e transformaram-se em costumes e tradições no Brasil.

\footnotetext{
${ }^{504}$ Manuel de Oliveira LIMA, “O espetáculo das ruas”, op.cit, 1996.

${ }^{505}$ Ruy CASTRO, op.cit, p.118-119.

${ }^{506}$ Manuel de Oliveira LIMA, “O espetáculo das ruas”..., op.cit, p. 599.

507 Trata-se da entrada das forças aliadas de ingleses, espanhóis e portugueses na França, ocasionando a queda do Império Napoleônico, em 31 de março de 1814. Em: André R.A. MACHADO; Carlos A.C. GANDRA JR; Eric R.G.ZEN; Fernanda SPOSITO; Renata I. C. CONSEGLIERE, orientação: Prof. Dr.István JANCSÓ, Cronologia de História do Brasil Monárquico (1808-1889). São Paulo: Humanitas/ FFLCH/USP,2000.

${ }^{508}$ Machado de ASSIS, op.cit.,p 66.
} 
Em A noiva da revolução (2006), também encontramos um longo trecho sobre festas populares explicado pela narradora, Maria Teodora:

As festas religiosas (...) eram os maiores acontecimentos daqui, além do entrudo. Cada igreja tinha a sua, sempre compondo uma novena - nove dias de música e hinos em louvor à Virgem ou ao santo padroeiro da paróquia - e o povo acorria em multidão. Por toda a parte havia festas só de negros e mulatos, enquanto da alta sociedade eram a de Nossa Senhora do Monte, em Olinda (onde já se via um pouco de mistura) e a do Poço da Panela, que eu frequentava desde menina. (...) As bandas de músicas militares saíam pelas ruas tocando marchas e fanfarras, e nas igrejas havia música sacra. (...) 509

Com isso, primeiro destaco: a narradora funciona como a "voz de uma professora" explicando vários aspectos da revolução de Pernambuco de 1817, do Brasil, de costumes e apresentando os perfis dos personagens. Os escritos dela no romance vêm sempre após os escritos de Domingos José Martins, seu esposo. E antes de cada trecho é destacado o respectivo narrador da seguinte forma: “Domingos Martins:" ou "Maria Teodora:". Portanto, ele como um dos líderes da revolução comenta ou narra alguma coisa e ela explica. Daí se configura a longa explicação de Maria Teodora sobre as festividades. Segundo ponto: temos um esboço das festas populares como tradição e costume no Brasil colônia e a relevância da religião. Além do Entrudo que corresponde ao Carnaval, as festas religiosas eram as mais frequentadas fora do centro do poder, o Rio de Janeiro, que tinha a presença da Família Real promovendo outras celebrações. Assim se destaca também a força e importância na religião no Brasil do século XIX.

Na sequência, Maria Teodora continua: "Nessa época ainda havia cavalhadas e desafios de cantadores - "manifestações de destreza física e expressões de um lirismo popular", nas palavras do padre João Ribeiro - mas estavam desaparecendo. ${ }^{510}$

Esse trecho apresenta um dado que se conecta às origens da poesia de Cordel no Brasil: os desafios de cantadores, ambos muito característicos da cultura pernambucana ainda hoje. Como exposto no início da dissertação, antes da poesia de Cordel começar a ser escrita e impressa, eram comuns os desafios de cantadores ou repentistas nas feiras e

\footnotetext{
${ }^{509}$ Paulo Santos de OLIVEIRA, op.cit., p.146-147.

${ }^{510}$ Ibidem, p. 147.
} 
festas populares, que parecem ser a origem dos folhetos e poesia de Cordel $^{511}$. Esse é o aspecto que a narradora destaca e que ilumina também um dado da cultura de Pernambuco e do (atual) Nordeste do Brasil.

\subsection{Brasil: Ideias e projetos}

Falar sobre a Independência do Brasil é também falar sobre um horizonte de expectativas $^{512}$, de um futuro que se almejava e se projetava com o fim do vínculo com Portugal. Dessa forma, nas muitas abordagens das obras literárias de caráter tão variado e publicadas em momentos tão diversos, foi possível observar, algumas vezes na voz dos poetas ou narradores, outras na voz dos personagens, planos e ideais sobre o futuro. São projetos que indicavam modelos de Brasil, com base em toda a herança baseada na experiência colonial e sociedade que se configurou.

Maria de Lourdes Viana Lyra em $\operatorname{artigo~}^{513}$ em que apresenta um balanço historiográfico até aquele momento (1992), lembra que os debates em torno das interpretações do processo de Independência se devem em grande parte a uma visão concebida de um único projeto nacional, construindo a unidade a partir da monarquia constitucional centralizadora. A autora aponta que essa concepção tem origem em uma corrente que construiu de forma intencional a visão de uma "unidade política no período colonial desde a criação do Governo-Geral"514. Aqui não apresentarei um debate historiográfico sobre o tema, mas chamo atenção para as muitas visões e projetos para o Brasil que passaram para a literatura, partindo do processo de Independência, da construção de narrativas, e da construção de uma memória coletiva (seja ela local ou nacional). Todos esses elementos estão vinculados a essa cultura de história, e o que pode parecer óbvio, talvez para historiadores que estudam o tema e conhecem múltiplas visões, não seja tanto para leitores não especialistas. Quando se faz uma análise de um conjunto de obras como a aqui apresentada, é possível verificar a complexidade da questão. São variadas as visões e projetos para o Brasil a partir das obras literárias, com focos diversos

\footnotetext{
${ }^{511}$ Márcia ABREU, op.cit., p.74

512 Reinhart KOSELLECK, Futuro passado: Contribuição à semântica dos tempos históricos. Rio de Janeiro: Contraponto: PUC Rio, 2006.

${ }^{513}$ Maria Lourdes Viana LYRA. "História e historiografia: a Independência em questão". In: Revista do Instituto Histórico e Geográfico Brasileiro. Rio de Janeiro, ano 153, n.377, out./dez. 1992, p.124-127.

${ }^{514}$ Ibidem, p. 126.
} 
e a partir da voz de quem o apresenta. Voz tomada no sentido do enunciador, seja um personagem (que equivale a visão de um grupo), um narrador ou poeta.

Na epopeia de Teixeira e Sousa (1847 e 1855) o que se destaca é o caráter patriótico da construção narrativa, a nosso ver, a narrativa de Teixeira e Sousa ajuda a consolidar a memória oficial da Independência, portanto, auxilia no projeto de unidade em torno da identidade coletiva. Ele atribui uma heroicidade aos sujeitos envolvidos por terem contribuído para libertar a "nação" das amarras de Portugal.

Muitos dos preceitos do Romantismo que imputavam uma ideia de nação e identidade, comuns ao Brasil e aos brasileiros, aparecem aqui. Embora Teixeira e Sousa se esforce para construir um poema épico, inspirado nesta tradição e seguindo a fórmula e métrica características, sua obra insere-se nas concepções do Romantismo no sentido de atribuir de forma anacrônica valores que não eram próprios da época retratada, ou seja, um patriotismo atribuído ao período da Independência. Importam as representações que o autor faz da Independência, seguindo uma memória oficial nacional, retratando D. Pedro I como o herói da nação, algo semelhante à representação do grito do Ipiranga que seria encontrada décadas depois na pintura de Pedro Américo em sua obra "Independência ou Morte!" "515. Este tipo de representação também passou aos livros didáticos e parte da historiografia, tendo o Instituto Histórico e Geográfico Brasileiro (IHGB), papel importante como difusor, no século XIX, desta memória da representação oficial e heróica da Independência do Brasil e atores envolvidos. Teixeira e Sousa tinha uma intenção didática de reiterar, e parcialmente formular, uma determinada visão da história da Independência do Brasil neste poema. O poeta destaca o intuito desta narrativa e destes feitos, ao serem reconhecidos como história, tornarem-se parte de uma memória. Enquanto projeto, é possível dizer que visava uma consolidação da memória da Independência dentro do escopo do período de forma coeva, por exemplo, com a atuação do IHGB no período, no último caso com fomento por parte de Pedro II para a produção de Histórias nacionais.

Em Memórias Póstumas de Brás Cubas (1880), de Machado de Assis, é notória a presença da escravidão, e o olhar agudo, sempre ácido e irônico de Brás Cubas. Acompanhando a vida do narrador defunto, na primeira metade do século XIX (Brás

\footnotetext{
515 Cecília Helena de Salles OLIVEIRA. "O Brado do Ipiranga: Apontamentos sobre a Obra de Pedro Américo e a Configuração da Memória da Independência". In: Cecilia Helena de Salles OLIVEIRA; Claudia Valladão de MATTOS (orgs.). O Brado do Ipiranga. São Paulo: EDUSP: Museu Paulista da Universidade de São Paulo, 1999. P.74-75.
} 
Cubas nasceu em 20 de outubro de 1805 e faleceu em agosto de 1869), o que se esboça é a transição da Independência, o Império, a Regência e parte do Segundo Reinado. O que se expressa no romance são passagens que não apenas explicitam o trato com a escravidão e com cativos, mas que apresentam como não se manifestava no horizonte daquele período o desejo de alteração da ordem vigente. O leitor acompanha valores de uma classe dominante, de políticos e comerciantes, homens de negócios que lucravam com o tráfico e com o trabalho escravo. O romance caracteriza e mimetiza uma face do Rio de Janeiro e da escravidão urbana, na primeira metade do século XIX. Assim, o projeto esboçado era de manutenção do regime escravista e divisão social com separação de grupos, uma classe dominante e subalternos.

Em Viva o povo brasileiro (1984), encontramos alguns trechos de personagens conversando sobre o futuro do país em que manifestam de forma muito clara suas intenções: a educação e a "condução" do país nas mãos de uma classe privilegiada e detentora do poder, que considerava o povo indigno e sem capacidade de aprendizado, uma "ralé" sem cultura e sem condições de ascensão. Estaria nas mãos daquela classe a condução do país e do povo, e o horizonte manifesto era a manutenção dos privilégios e divisão social. O cenário é a região do Recôncavo Baiano em que se destacam as plantations e os negócios com pesca. A proximidade dos proprietários de grandes fazendas e negócios do ramo da pesca com políticos é colocada de forma evidente na narrativa, são os grandes mandatários da região.

Quando o Cônego visitador D. Francisco Manoel de Araújo Marques, conversa com Amleto Ferreira (pai de Patrício Macário que terá um filho com Maria da Fé), mestiço que começou como guardador de livros do Barão de Pirapuama, ascendendo e virando administrador de seus negócios quando aquele adoeceu. A partir do momento em que o Barão morre leva adiante seus próprios negócios, o que o leva a uma ascensão social. O cônego conversava com o Barão e outros convidados pertencentes a aristocracia do Recôncavo, sobre filosofia natural e se sente ultrajado com a interferência de Amleto na conversa. Com isso, o religioso discorre sobre o papel dos mestiços no Brasil. Para o personagem, os mestiços deveriam ocupar um local medianeiro, que cuidasse de assuntos intermediários (a capatazia), demarcando uma divisão para que a ascensão da classe dominante ficasse garantida: “ Eis aí onde se encaixa como uma luva o contigente de mestiços na perfeita organização social, a única que poderá conferir a este país uma élite, 
como dizem os franceses, uma nata, uma aristocracia capaz de, como a grega, produzir e fazer medrar uma cultura de escol." ${ }^{516}$

O cônego e o Barão e Pirapuama tipificam o grupo mandatário no Brasil da época e como pensavam, refletindo dessa forma o projeto de futuro que vislumbravam. No trecho a seguir é traduzido como se condensava esse horizonte para esse grupo, qual era o Brasil, ou projeto engendrado:

- O elemento servil é indipensável para que se mantenha o país e a sociedade - comentou, cruzando as mãos às costas. - Nisto concordo, sem ele os custos tornar-se-iam proibitivos e não se poderia aspirar a transformar esta nação no celeiro do mundo civilizado e no fornecedor de algumas das principais riquezas de que depende a civilização. ${ }^{517}$

Finalizando o raciocínio, conforme esse grupo, quando a vinda da Missão Francesa é citada e se adentra no plano da educação e cultura, se coloca o seguinte: "Continuaremos a tratar o nosso elemento servil melhor do que tratam o elemento servil nos países civilizados? Permitiremos que a educação se faça da mesma forma para todas as classes, assim perpetuando e agravando a degradação já tão tristemente exibida em toda parte $?^{518}$ A educação, portanto, era reservada apenas para um grupo seleto, mantendo uma divisão social em que não possibilitasse o acesso de pessoas dos grupos considerados subalternos, ou o povo. Formalizando, desse modo, a manutenção de um grupo detentor do poder, educação e cultura que considerava que o "destino" da nação se encontrava em suas mãos. Assim, é possível acompanhar não apenas um modelo do pensamento de um grupo, mas um projeto para o Brasil no século XIX, que foi mimetizada no romance de João Ubaldo.

A menção ao tratamento do elemento servil, embora pareça despropositada, foi abordada por Luiz Costa Lima em artigo que aborda interpretações a respeito da cordialidade do brasileiro, e expõe trecho de uma resenha publicada pelo geógrafo Éliseé Reclus, em que compara a escravidão no Brasil e nos Estados Unidos ${ }^{519}$, publicada em

\footnotetext{
${ }^{516}$ João Ubaldo RIBEIRO, op.cit, p.130.

517 Ibidem, p.75.

518 Ibidem, p. 135.

${ }^{519}$ Para uma estudo comparativo da escravidão no Brasil e Estados Unidos recomendamos: Tâmis Peixoto PARRON, A política da escravidão na Era da Liberdade: Estados Unidos, Brasil e Cuba, 1787-1846. Tese de Doutorado apresentada ao Programa de Pós-Graduação em História Social, do Departamento de História da Faculdade de Filosofia, Letras e Ciências Humanas\FFLCH da Universidade de São PaulolUSP.São paulo, 2015.
} 
1863 baseada na Viagem pelo Norte do Brasil no Ano de 1859, do médico sanitarista Von Avé-Lallemant ${ }^{520}$. Costa Lima transcreve um longo trecho da resenha em que o geógrafo aponta que sob o manto do trato patriarcal, se argumentava na época, comparativamente, que a escravidão no Brasil se revestia de benesses que os cativos norte-americanos não encontravam. Tais como o gozo de certa liberdade nos domingos (como nos Estados Unidos), mas também em feriados ao longo do ano; ou a concessão quinzenal de folga para que os cativos no Brasil pudessem cultivar suas próprias hortas, ou cita exemplos de alguns ex-cativos que podiam tornar-se cidadãos ${ }^{521}$, entre outros exemplos expostos por Reclus. ${ }^{522}$ Assim, o geógrafo discorre sobre as relações complexas que se desenvolveram entre senhores e escravos, que em alguns momentos ganhavam contornos mais dóceis no trato, revestidos pelo patriarcalismo, mas por qualquer motivo que desagradasse o senhor ou a senhora, estes se revestiam de tirania e aplicavam castigos cruéis aos cativos, mesmo que possuíssem relação estreita revestida de afeto ${ }^{523}$. Assim, resume Reclus: "Todos esses fatos são da maior importância para o futuro do país, mas não podem servir de desculpa para a escravidão brasileira, que, por sua própria natureza, é idêntica à 'instituição divina' dos anglo-americanos." 524

Luiz Costa Lima, destaca a respeito da cordialidade o essencial da análise de Reclus, o espaço privado. Sendo a escravidão naturalizada em todas as esferas sociais no Brasil (Estado, ordens religiosas, pelo senhor de terras), dissolveu- se a noção de espaço público "onde haveria de imperar, ao menos idealmente, o espaço da lei, a norma válida para todos." 525 João Ubaldo Ribeiro, quando escreveu seu livro, apenas transmitiu na voz de um personagem discussões do século XIX, como expressas no relato do viajante. Dessa forma, a suposta "cordialidade" se apresenta na obra, também manifesta em outras passagens, sobretudo da baronesa, esposa de Perilo Ambrósio, no trato com as cativas que trabalhavam em sua casa.

\footnotetext{
${ }^{520}$ Luiz Costa LIMA, "A pouco cordial cordialidade". In: Revista USP. São Paulo, n.110, p.107-114, julho/agosto/setembro 2016.

521 Tâmis Parron esclarece que o comércio de seres humanos definiu a concepção de cidadania no Brasil. A Comissão de Constituição (1823) "decidira que o campo dos direitos individuais seria dividido em duas categorias: a dos brasileiros, dotados de direitos civis, e a dos cidadãos, investidos de políticos. Os escravos da Affrica que recebessem alforria seriam considerados brasileiros, mas apenas os brasileiros alforriados seriam cidadãos (art. 5 e art. 123). Pertencer ao grupo dos brasileiros não era pouca coisa. Gozava-se de liberdade individual, julgamento em tribunal competente, direito à fiança, isenção de serviços involuntários e liberdade de imprensa (art.7)." Foram mantidos os grifos do autor. Em: Tâmis Peixoto PARRON. "Somatória de experiências: Brasil, 1808-1831", op.cit., p.179.

${ }^{522}$ Luiz Costa LIMA, op.cit., p.111.

${ }^{523}$ Ibidem, p.111-112.

${ }^{524}$ Ibidem, p. 112.

${ }^{525}$ Ibidem, p. 112.
} 
Após a apresentação dos diálogos de personagens de Viva o povo brasileiro (1984), em que se expôs muito do pensamento, do ideal de um projeto de nação que se formava a partir do ponto de vista de uma classe dominante, temos um resumo de intenções nessa frase: “A arte da política nada mais é que isto: é a arte da conservação do bom e da extirpação do mau." ${ }^{526}$ A divisão do bom e mau neste caso parte da autoconsideração desse grupo, que seriam os condutores da nação, e o elemento servil significava, na visão destes personagens, a degradação da nação. Assim, projetavam a conservação de seus interesses e privilégios, mantendo a divisão social para a manutenção de seus projetos.

Como contraponto ao projeto de uma classe dominate, e como já apresentado na análise do conceito "revolução" 527 , se delineava na visão dos "subalternos", do povo, um projeto de justiça social. Com a abolição os ex-cativos não foram absorvidos socialmente, não houve um planejamento de integração social do grupo, assim, ficaram marginalizados. Nas palavras de Maria da Fé, anos depois, no contexto da Guerra de Canudos (1897-1897) onde discute com Filomeno, oficial do exército da República que estava preso:

E agora você vêm falar da República? Por que não nos falam de comida, de terra, de liberdade? Por que, enquanto, hipocritamente libertam os negros, porque não mais precisam deles, criam novos escravos, ajudam a transformar seu país na terra do povo humilhado e sem voz? Sua República é um novo embuste, dos muitos que nos perpetraram e perpretarão... ${ }^{528}$

A personagem encerra dizendo que a guerra civil não terminará com a batalha de Canudos, que continuará tempos afora, assumindo muitas faces "e nunca deixará de assombrar vocês, até que cesse de existir um país que em vez de governantes tem donos, em vez de povo tem escravos, em vez de orgulho tem vergonha." ${ }^{529}$ Enquanto na visão de uma classe dominante permanecer o plano de uma divisão social, que ao longo do romance vai se reprojetando mesmo com a alteração das formas de governo, haverá a resistência a esse projeto. Que alude a uma outro ideal de Brasil, um outro projeto idealizado nos personagens que representam os subalternos, ou o povo.

\footnotetext{
526 João Ubaldo RIBEIRO, op.cit., p.136.

$527 \mathrm{O}$ conceito foi analisado no capítulo 1 .

${ }^{528}$ Ibidem, p.553.

${ }^{529}$ Ibidem, p.553.
} 
Os romances sobre a revolução de Pernambuco de 1817 apresentam um projeto alternativo ao governo central do Rio de Janeiro, embora já destacado que se tratava de um projeto vago com uma ideia igualmente vaga de república. Mas os romances se referem de maneira ostensiva ao projeto alternativo como uma república. É sabido que a província ganhou o apoio de províncias vizinhas (Paraíba, Ceará, Rio Grande do Norte e Alagoas ) e o projeto alternativo não se restringia a elas mas planejava se disseminar para o sul. Embora tenha sido discutido, não foram incluídos planos de abolição da escravatura. Portanto, se havia recusa do modelo realista constitucional como o do Rio de Janeiro e se imaginava algo diferente, em sua estrutura o peso da escravidão e apoio que a revolução perderia de grandes senhores de terras e de negócios, não parecia ser diferente, pelo menos a curto e médio prazo. Este modelo de "república" que se delineava mantinha estruturalmente a base econômica tal qual a monarquia constitucional.

Nos projetos há, portanto, uma unidade que estruturava o Brasil colônia e o Brasil Império: a escravidão. A partir dela as políticas e defesa de privilégios demarcavam uma divisão social, como um projeto, a permanência de um modelo que já vinha atravessando séculos. No caso de Teixeira e Sousa, o projeto é demonstrado na concepção da obra como consolidação da memória da Independência com atuação central de D. Pedro.

Roger Chartier, explicando sobre o modo como entende "história cultural", assinala: "a história cultural [...] tem por principal objeto identificar o modo como em diferentes lugares e momentos uma determinada realidade social é construída, pensada,

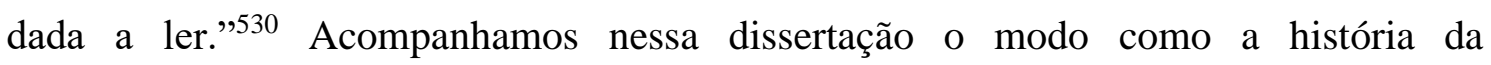
Independência do Brasil, sob perspectivas variadas foi construída, pensada e dada a ler ao longo do tempo. Neste tópico em que foram analisados projetos de Brasil a partir das obras literárias, manifestos através de olhares e vozes diversas de personagens, narradores, e autores em distintos tempos, foi possível identificar como se projetavam perspectivas de futuro que ratificassem ou transformassem radicalmente a realidade dos sujeitos de cada período. O foco é o período da Independência, mas através dos temas, em alguns momentos, transgredimos o recorte cronológico a partir da proposta das obras aqui analisadas. No que se refere a projetos ou ideias de Brasil, esse tema se conecta imediatamente com a Independência, enquanto Estado autônomo.

Quando adentra uma definição de representações Chartier salienta:

\footnotetext{
${ }^{530}$ Roger CHARTIER, A história cultural entre práticas e representações. Maria Manuela GALHARDO (tradução). Algés: Memória e Sociedade: DIFEL, 2002, p. 16-17.
} 
as representações do mundo social assim construídas, embora aspirem à universalidade de um diagnóstico fundado na razão, são sempre determinadas pelos interesses de grupo que as forjam. Daí, para cada caso, o necessário relacionamento dos discursos proferidos com a posição de quem os utiliza. ${ }^{531}$

O esforço, portanto, é demonstrar como essas representações não são unas, nem mesmo quando analisamos cuidadosamente uma obra isolada, respeitando as vozes dos que evocavam os discursos, fator de extrema importância pois insere e direciona olhares e perspectivas, muitas vezes, diametralmente opostas. Sobretudo, levando em conta a formação do Brasil. O respeito aos "representantes" das vozes se evidenciou nesta dissertação desde uma interpretação da Independência do Brasil, passando para alguns dos conceitos examinados, e também presente em muitos temas apresentados neste terceiro capítulo. No próximo item, em que serão analisadas concepções de história encontradas em algumas obras que se destacaram, o cuidado em relacionar o discurso com a posição de quem os profere, mostra-se como fator de suma importância.

\subsection{História e Memória}

Ao longo da pesquisa foi possível acompanhar algumas questões relacionadas à construção de uma memória e de uma história oficial da Independência do Brasil. A versão supostamente tida como oficial foi recebendo, nas obras ficcionais aqui analisadas, tratamento distinto através do humor, de forma a depreciá-la e afastá-la do tom heróico. Foi possível perceber também que, no século XIX a história da Independência era narrada de forma ampla e processual, mostrando as várias lutas que ocorreram no território brasileiro em diversas províncias, e as disputas de poder em torno de projetos variados. A partir do século XX, com base na análise da Revolução Pernambucana e das lutas de independência na Bahia, foi possível identificar que parece haver um progressivo ofuscamento dessas lutas, o que pode ser indicativo de uma quebra de um entendimento processual da Independência do Brasil. Os autores passam a usar apenas episódios marcantes traçados numa linha cronológica, em torno da atuação dos monarcas, com ênfase no Sudeste.

\footnotetext{
${ }^{531}$ Roger CHARTIER, op.cit., p.17.
} 
Com base no corpus de obras analisadas nesta dissertação, os escritores (a partir do século XX) que evidenciam ou relembram essas lutas, a revolução de Pernambuco e a expulsão de tropas de Portugal na Bahia, são originários da região Norte e Nordeste do Brasil, o que também assinala um engajamento indicativo de que ocorre certo "esquecimento" ou negligência com a memória da história dessa região. Ressalto que se no século XIX isso não ocorria foi ao longo do tempo que esse processo se desenvolveu.

Na epopeia de Teixeira e Sousa (1847 e 1855), História e a Memória, escritas com letra maiúscula, representam um "lugar" e possuem um valor especial para o poeta. Em sua obra, a História é definida como "imparcial”: "Oh! com que nome a imparcial

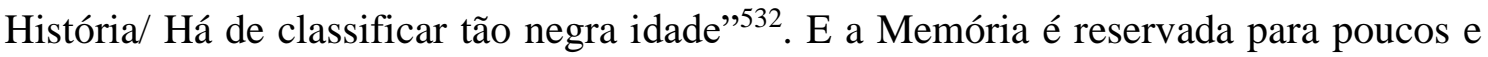
grandes nomes e eventos. No poema é possível perceber que havia uma consciência, um ideal e preocupação grande sobre o modo como iria se adentrar para a História. É possível perceber esse valor em algumas passagens, como a que segue:

Resplende ante sua alma a Eternidade!/ Ali o Anjo imparcial da História / Votando ao Nome seu perpetuidade./ Os grava nos Padrões d'alta Memória!/ E Ele entre os Heróis da Liberdade/ Brilha com eterna auréola de Glória!/ Seu Nome no universo decantado,/ Como o de Herói prestante é aclamado! ${ }^{533}$

A História portanto emerge como um "lugar-entidade" acima de tudo, destinada a grandes exemplos. Reinhart Koselleck analisando o percurso do topos Historia Magistra Vitae $^{534}$ (História mestra da vida) ao longo do tempo, afirma que após a Revolução Francesa a história tornou-se um "sujeito ao qual foram designados atributos divinos como "toda-poderosa", "justa", "equânime" e "sacra"." 535 Embora não possamos ignorar as características da construção poética da epopeia ${ }^{536}$, na obra de Teixeira e Sousa, há uma elaboração da história como sujeito e lugar, assim a história tornou-se "imparcial" e reservada a poucos que seriam preservados pela Memória. Seguindo o rastro de uma

\footnotetext{
${ }^{532}$ Antonio Gonsalves TEIXEIRA E SOUSA, op.cit., Tomo II, p.312.

533 Ibidem, p. 259.

${ }^{534}$ Reinhart KOSELLECK. "História Magistra Vitae - Sobre a dissolução do topos na história moderna em movimento." In: Futuro passado: Contribuição à semântica dos tempos históricos. Rio de Janeiro: Contraponto: PUC Rio, 2006, p.41-60.

535 Ibidem, p.50.

${ }^{536}$ Aqui me refiro ao uso de maiúsculas na escrita das palavras História e Memória, assim como em Anjo, Liberdade, Musa. É uma característica própria do gênero literário e do poema de Antonio Gonsalves Teixeira e Sousa.
} 
percepção da história na obra, já no Canto final, quando o "anjo da imortal Verdade pousa nos lábios de Clemente Pereira ${ }^{537}$ em discurso proferido a D. Pedro I no dia de sua aclamação", temos o seguinte exemplo:

- O quanto se passara na memória,/ Nas Américas todas existia:/ Graves, sábias lições brotava a História!/ O Brasil vigoroso inda crescia:/ O velho Portugal d'antiga glória,/ Exausto de seus meios, decaia;/ Fácil era ao Brasil na mocidade/ Suster o velho irmão na velha idade! ${ }^{538}$ (grifos meus)

E ainda, em outro exemplo:

- De amor da liberdade assás já dado/ Tinha todo o Brasil provas veementes;/ Havia toda a América quebrado/ Do domínio europeu férreas correntes:/ Os filhos deste solo denodado/ Não são que os Brasileiros mais valentes:/ Nem Portugal mais poderosa terra/ Que a velha Espanha, a férvida Inglaterra! $!^{539}$ (grifos meus)

Se, como explicitado anteriormente, temos a História como "sujeito-lugar" de grandes exemplos para a posteridade ou, visto de ângulo inverso, grandes exemplos do passado, no trecho destacado acima, da História emergiam lições da experiência da América espanhola. É a Historia magistra vitae com uma diferença: se tratava de um passado muito próximo que ainda ressoava como exemplo no presente, um passadopresente para os personagens do poema.

Em Memórias Póstumas de Brás Cubas (1880) encontramos dois capítulos que abordam a História. No primeiro, "A ideia fixa" ${ }^{440}$, Brás Cubas discorre sobre a sua invenção: o emplasto Brás Cubas. Entretanto, numa digressão que o narrador faz, a partir de alguns exemplos que narra, é possível distinguir algumas noções de História. Num primeiro momento, discorrendo sobre a ideia fixa que matou Cavour, a unidade italiana, completa: "Verdade é que Bismarck não morreu; mas cumpre advertir que a natureza é uma grande caprichosa e a história, uma eterna loureira." ${ }^{541}$ Adiante, a natureza entrará

\footnotetext{
537 José Clemente Pereira foi presidente do Senado da Câmara do Rio de Janeiro, e ocupando esse cargo, falou em nome do povo do Rio de Janeiro.

${ }^{538}$ Antonio Gonsalves TEIXEIRA E SOUSA, op.cit., Tomo II, p.293.

${ }^{539}$ Ibidem, p.294.

${ }^{540}$ Machado de ASSIS, “A ideia fixa”, op.cit., 2014, p.40 - 42.

${ }^{541}$ Ibidem, p.40.
} 
em cena novamente mas neste momento ela é "caprichosa" e a história "eterna sedutora". Seguindo sua digressão, Brás Cubas completa: "Viva pois a história, a volúvel história que dá para tudo; e tornando à ideia fixa, direi que é ela a que faz os varões fortes e doudos..." 542 Além de sedutora, a história para Brás Cubas, é inconstante. Completando o panorama, o narrador finaliza: "Deixemos a história com os seus caprichos de dama elegante." ${ }^{543}$ Assim a imagem se completa: a história foi "personificada" analogamente à figura de uma mulher (eterna) sedutora, volúvel e caprichosa, no último aspecto se igualando à natureza.

Ao fim, narrando sobre o emplasto, o narrador encerra: "Quem não sabe que ao pé de cada bandeira grande, pública, ostensiva, há muitas vezes várias outras bandeiras modestamente particulares, que se hasteiam e flutuam à sombra daquela, e não poucas vezes lhe sobrevivem?" "544 Uma possível leitura, são as muitas causas, projetos defendidos pelo coletivo e pelo singular. Essa possível interpretação pode ser projetada para Estados e nações (coletivo), e instituições, grupos ou indivíduos (singular). Com isso, é possível, inclusive, observar que pode haver uma gradação entre o que pode ser o coletivo, "as grandes bandeiras" e o singular "as bandeiras modestamente particulares", e o emprego de "modestamente" soa carregado de ironia, apontando o oposto. Poderia ser a nação o coletivo e a escravidão (enquanto instituição) o singular; ou a escravidão (coletivo) e os grupos opostos (o singular), ou seja, uma classe dominante e os escravizados. Contudo, Brás Cubas se referia ao emplasto e a partir desse comentário foi possível expandir uma interpretação, um sentido.

No capítulo seguinte, "Delírio"545, a Natureza e a História figuram novamente. Brás Cubas encontrava-se enfermo, momento em que tem um sonho ou uma visão: um hipopótamo o levava à origem dos séculos, então ele encontra a Natureza ou Pandora. Ela, segundo o narrador, é mãe e inimiga e iria tirar-lhe a vida, ele negociava pois não queria morrer, e acusa que a Natureza se mostrava egoísta. Ela então lhe responde: "Sim, egoísmo, não tenho outra lei. Egoísmo, conservação. A onça mata o novilho porque o raciocínio da onça é que ela precisa viver, e se o novilho é tenro tanto melhor: eis o estatuto universal." ${ }^{546}$ Para provar o que falava, Natureza ou Pandora então o arrebata ao alto de uma montanha e o narrador então vislumbra o desfilar dos séculos e ele assiste a

\footnotetext{
542 Ibidem, p.41.

543 Ibidem, p.41.

${ }^{544}$ Ibidem, p.41-42.

${ }^{545}$ Machado de ASSIS, "Delírio", op.cit., 2014, p.49-55.

${ }^{546}$ Machado de ASSIS, op.cit, p.53.
} 
tudo, esperando chegar o seu. Os séculos vão passando rapidamente e turbulentos, e Brás Cubas aponta:

Ao passo que a vida tinha assim uma regularidade de calendário, fazia-se a história e a civilização, e o homem nu e desarmado, armava-se e vestia-se, construía o tugúrio e o palácio, a rude aldeia e Tebas de cem portas, criava a ciência, que perscruta, e a arte que enleva, fazia-se orador, mecânico, filósofo, corria a face do globo, descia ao ventre da terra, subia à esfera das nuvens, colaborando assim na obra misteriosa, com que entretinha a necessidade da vida e a melancolia do desamparo. ${ }^{547}$

Assim, o tempo vai se acelerando e finalmente chega seu século (o XIX), e na sequência dele os futuros. Brás Cubas diz: "Aquele vinha ágil, destro, vibrante, cheio de si, um pouco difuso, audaz, sabedor, mas ao cabo tão miserável como os primeiros, e assim passou e assim passaram os outros, com a mesma rapidez e igual monotonia." 548

Dessa forma, depreende-se que há uma projeção da história, numa linha linear e constante, essa história segue, cada século com sua novidades, com suas invenções, é destacado um processo de transformações e uma aceleração no transcorrer dos séculos do tempo -, mas o século XIX (de Brás Cubas) e os futuros passam da mesma forma. O que se apresenta aí é uma constância da história, geração após geração, não há uma grande ruptura, é o que a Natureza ou Pandora quer provar para Brás Cubas: a conservação, a "lei do mais forte sobre o mais fraco".

Projetando a metáfora para o século XIX, de Brás Cubas, no contexto em que o livro foi concebido de apresentação da classe dominante, meio que Brás Cubas pertence, observa e produz suas críticas irônicas, tendo o modelo escravista e as relações entre senhores, cativos e libertos no cenário urbano do Rio de Janeiro, a analogia da onça e do novilho pode funcionar como uma alusão. Essa visão da história chama a atenção devido ao futuro não se apresentar como revolucionário, embora ocorram as modernizações na vida dos Homens os séculos passam da mesma forma como os anteriores. Apesar de todas as inovações e transformações, os séculos caminham de maneira invariável "com igual monotonia", assim, o progresso é acompanhado de uma "melancolia do desamparo". Dessa maneira, as novidades que surgem servem à conservação, e aqui expandimos: pode

\footnotetext{
${ }^{547}$ Ibidem, p.55.
}

548 Ibidem, p.55. 
ser a conservação da vida, de privilégios, de instituições, a "lei do mais forte sobre o mais fraco". Talvez a monotonia se refira a uma pressuposição de mudanças e renovações na sociedade invariavelmente já esperadas, independente de quais fossem, assim como a melancolia do desamparo possa se referir "as gerações que se superpunham às gerações" 549 , e a certeza que ao final "todas seriam pontuais na sepultura" ${ }^{550}$. Retomemos as primeiras noções que Brás Cubas desenvolveu: a natureza como caprichosa, "egoísta", seguindo para a lei da conservação. A isso, se acrescenta a história primeiramente sedutora, volúvel e caprichosa, assim como a natureza. Aqui o narrador aponta a insconstância da história (ela era volúvel, com os "caprichos de dama elegante"), no capítulo seguinte há a contradição, ou seja, os séculos e a história são apresentados através de uma constância e apesar do progresso, são enfadonhos, cansativos. Por fim, retomando a conservação que figura nos dois capítulos, na noção evidenciada pelas bandeiras, há mais um jogo de opostos, na primeira acepção são as bandeiras particulares que "não poucas vezes" sobrevivem à sombra das públicas e ostensivas, e no sentido seguinte, a lei do mais forte sobre o mais fraco, o primeiro (o mais forte) suplantando o segundo. Aliás, há uma leitura possível de opostos, mas também podem ser concepções complementares. O que sobressai dessas noções conjugadas é a preservação da sobrevivência.

Como um contraponto a essas concepções da História e da Memória, a história imparcial e para grandes sujeitos e momentos, como encarada no século XIX, de acordo com a concepção de Teixeira e Sousa, temos a forma como história e memória são tratadas já no século XX. Encontramos muitos questionamentos levantados acerca, não apenas sobre o que entraria para a história, mas também sobre quem escreve/ produz essas histórias e narrativas, e de acordo com quais interesses. Muitas dessas questões, inclusive, foram colocadas como "provocações" para reflexão por um personagem da obra de João Ubaldo Ribeiro, Viva o povo brasileiro (1984). Trata-se de um conhecido contador de histórias do Recôncavo Baiano, o cego Faustino, que aponta que a História não é só o que está nos livros - e nisso reflete-se também uma valorização da história oral, pois o questionador é um contador de histórias -, e na trama do romance, ele conhece a outra (e verdadeira) história de Perilo Ambrósio. Faustino diz que muitos escritores são mentirosos, e começa a contar sobre o incêndio da biblioteca de Alexandria ("Alsandria",

\footnotetext{
${ }^{549}$ Machado de ASSIS, op.cit., p.54,

${ }^{550}$ Ibidem, p.55.
} 
como o personagem a chama), segundo diz: "que nela tudo continha sobre o conhecimento" ${ }^{551}$ :

Desde esse dia [do incêndio] que se sabe que toda a História é falsa ou meio falsa e cada geração que chega resolve o que aconteceu antes dela e assim a História dos livros é tão inventada quanto a dos jornais, onde se lê cada peta de arrepiar os cabelos. Poucos livros devem ser confiados, assim como poucas pessoas, é a mesma coisa.

Além disso, continuou o cego, a História feita por papéis deixa passar tudo aquilo que não se botou no papel e só se bota no papel o que interessa....Então toda a História dos papéis é pelo interesse de alguém.

E tem mais.... O que para um é um grande acontecimento, para outro é vergonha a negar. O que para um é importante, para outro não existe. Por conseguinte, a maior parte da História se oculta na consciência dos homens e por isso a maior parte da História nunca ninguém vai saber, isto para não falar em coisas como Alsandria, que matam a memória. ${ }^{552}$

Posto que esta pesquisa também discute cultura, a memória e escrita da História em múltiplas narrativas, algumas questões podem ser levantadas. Embora o tema seja delicado, o que o personagem coloca é que a produção de narrativas e da escrita da História sempre parte de algum interesse, e no caso de histórias nacionais seriam os interesses de um grupo dominante. Como apontado no capítulo 2 , temos a construção da história do personagem Perilo Ambrósio alçado ao status de herói da Independência. Ele foi recompensado com o título de Barão, se transformando num dono de grandes propriedades, negócios e influência política, além de reconhecimento público e entrou para os "anais da História e Memória" do país e da Bahia a partir de uma farsa. A forma como a história do personagem foi construída e narrada por outros personagens no enredo do livro produz no leitor inquietações acerca da escrita da História e de forma mais imediata, da história de seu país, seus marcos e heróis. Como uma alternativa à história do Barão de Pirapuama destacam-se os muitos "heróis anônimos" e "revoluções silenciosas", que remetem não apenas ao povo e suas lutas diárias no contexto do período representado e do livro, mas também ao grupo de "subalternos" buscando por justiça e

\footnotetext{
551 João Ubaldo RIBEIRO, op.cit, p.506.

552 Ibidem, p.506-507. "Alsandria” é a biblioteca de Alexandria.
} 
dignidade. Essas provocações na leitura, podem levar a reflexões por parte do leitor sobre a História.

No capítulo final de Viva o povo brasileiro (1984), quando Patrício Macário, já centenário, falece, três ladrões roubam o baú onde guardava a canastra que havia pertencido a Júlio Dandão. A canastra continha segredos do passado e do futuro, de uma forma sobrenatural, e pertencia à "Irmandade Povo brasileiro", fundada por três cativos na Casa da Farinha. Os três ladrões se escondem na casa da Farinha, já abandonada. O que se passa é que um dos ladrões consegue espiar por uma fresta o que há dentro da canastra, e se produz um efeito semelhante ao capítulo "Delírio" de Memórias Póstumas de Brás Cubas (1880). O ladrão Nonô então vê o futuro: ladrões de terno de alta estirpe, guerras, misérias, a barbárie. Então das paredes da casa da Farinha começa a escorrer sangue, que passa a jorrar por todos os cantos e pela terra, momento em que os três ladrões fogem. A casa da Farinha e a canastra são soterradas em sangue. No trecho final, acima do céu encontra-se o "Poleiro de Almas" que estavam muito agitadas querendo brigar, decididas a "voltar para lutar" 553 : "Ninguém olhou para cima e assim ninguém viu, no meio do temporal, o Espírito do Homem, erradio mas cheio de esperança, vagando sobre as águas sem luz da grande baía." 554 (grifos meus)

Esse episódio do livro se passa em 1939, tudo o que os ladrões viram na canastra, portanto, era o que se seguiria na história, a história contemporânea como se passou a partir daquele ano, as referências fazem menção à história real, a bomba nuclear, à guerra, entre outros possíveis exemplos.

A cena foi narrada para chegarmos ao ponto: "futuro" e "esperança". Acompanhando a trama do livro observamos o tratamento da história, que passa em diálogos dos personagens ou na voz do narrador em muitos momentos. Na voz do contador de histórias, o cego Faustino, ela é questionada e há a contestação sobre a narrativa de heróis da história, sobre a escrita, a produção e os livros de história, momento em que a "imparcialidade", como a história apresentada no épico de Teixeira e Sousa (1847 e 1855), se esvai.

Quando analisamos o conceito "revolução" 555 , na voz dos personagens que lutavam pelo povo falava-se em uma luta que continuaria através dos tempos, contra a

\footnotetext{
553 João Ubaldo RIBEIRO, op.cit., p.657.

${ }^{554}$ Ibidem, p.657.

${ }^{555}$ A análise do conceito encontra-se no capítulo 1, e no item 3.4 onde examinamos ideias e projetos de Brasil, há trecho complementar a luta que continuaria através dos séculos.
} 
opressão, contra as injustiças, e o livro retoma essa ideia no final, com as "alminhas que brigavam para voltar e lutar" e o "Espírito do Homem que pairava no céu cheio de esperança". Após a visão cataclísmica do futuro (da história?) na canastra, há a projeção da luta e esperança anunciando "nascimentos" (as almas que querem voltar), ou seja, o futuro. A história se projeta para o futuro, um futuro de lutas na busca de uma ruptura, de uma quebra dessa história, o anúncio de um novo sentido, de uma nova história. Retomando Koselleck, o autor aponta que a partir do século XVIII, com a aceleração do tempo compreendida como a aproximação do Juízo Final, o conceito histórico passou a ser relacionado à esperança, que com a Revolução Francesa e a disseminação da técnica, a precipitação do futuro desejado ganhou teor de realidade. ${ }^{556}$

Passamos, portanto, pela História personificada, imparcial, em que figuravam acontecimentos e sujeitos exemplares que eram alçados à Memória um lugar reservado a poucos e especiais, na epopeia de Teixeira e Sousa. Nesse autor também vimos a "história mestra da vida" fornecendo exemplos que poderiam ser seguidos, alcançados ou rejeitados. Seguimos com Machado de Assis, em que a história aparece com constância, e é realçado o plano da sobreposição dos que detém mais força e poder sobre os mais frágeis, para conservação, embora não raras vezes os mais frágeis sobrevivam à sombra dos mais fortes. O futuro se apresenta "sabedor", “audaz", "vibrante”, mas passa como os anteriores, sem uma grande mudança, algo que causasse uma ruptura da história. Destaca-se a sobrevivência e a "melancolia do desamparo". Chegamos na concepção de história em João Ubaldo Ribeiro, com indagações acerca da escrita da história, sua produção e os interesses dos que selecionam o que entra para a história e para os livros. ${ }^{557}$ O futuro se projeta com a esperança e a luta para uma modificação da ordem vigente fica anunciada. A história sendo, portanto, no caso brasileiro associada ao plano político e de formação do Brasil e divisão social advinda daí.

Houve uma valorização das histórias salientando pontos de vista alternativos e oferecendo destaque a indivíduos marginalizados. Uma história que reconhecesse esses sujeitos, os heróis anônimos, após longo período em que se privilegiavam as grandes narrativas nacionais e lutas políticas. Porém, acompanhando essa trajetória, do lugar, do tratamento que a História dispunha e sua transformação, a inquietação que pode provocar

\footnotetext{
${ }^{556}$ Reinhart Koselleck, op.cit., p.58

${ }^{557}$ Mais uma vez, ressaltamos o momento de publicação, 1984, na abertura política da Ditadura Militar. O questionamento na obra sobre o que iria entrar para a história e os livros, que ocorrem de acordo com os interesses de uma classe mandatária, pode ser projetado com preocupações do período da publicação.
} 
no historiador, pensando nas provocações de Viva o povo brasileiro (1984), são aberturas que demonstrem uma perda de valorização ou de importância para a História e o trabalho do historiador, extrapolando o livro que não faz isso, podendo chegar a limites da negação histórica, de forma completamente ideológica.

Nessa análise, a partir de questionamentos postos em Viva o povo brasileiro (1984), o cuidado sobre a posição de quem profere o discurso é extremante relevante. Retomando Chartier: “as percepções do social não são de forma alguma discursos neutros: produzem estratégias e práticas (sociais, escolares, políticas) que tendem a impor uma autoridade à custa de outros, por elas menosprezados, a legitimar um projeto reformador ou justificar, para os próprios indivíduos, as suas escolhas e condutas." 558 Foi perceptível no exame das obras literárias, o cuidado dos escritores em projetar nos personagens as disputas, a oposição, as lutas contrapostas pela realidade e experiência de cada grupo representado. Dái se apresentam concepções, significados e interpretações de projetos, conceitos e percepções da História, como ela se produz, e como suas narrativas se consolidam nas sociedades de maneiras diversas e muitas vezes opostas.

Representações, portanto, não se manifestam apenas pelo exame da produção de cada autor, separando as representações por obras, mas também através de investigação e indagações internas de cada obra. Se temos uma tessitura de tempos se entrelaçando nessa pesquisa, não apenas pela análise de longa duração, mas pelos muitos tempos de escrita e leituras das obras literárias, temos também uma tessitura de representações se enredando.

Não se pretende entrar no debate da produção de narrativas a partir da virada linguística, como já apontado no início da dissertação, apenas chamar atenção às reflexões sobre a história e a memória. Assim, ampliamos a análise para a memória adentrando o tema da Independência e a produção de seus marcos, pois compõe uma memória coletiva do país.

Paul Ricoeur, refletindo sobre o entrecruzamento entre história e ficção, ${ }^{559}$ argumenta que uma comunidade histórica seleciona os acontecimentos que considera marcantes porque enxerga neles uma origem ou um redirecionamento: "Esses acontecimentos geram sentimentos de uma intensidade ética considerável, quer no registro da comemoração fervorosa, quer no da execração, da indignação, do lamento, da

\footnotetext{
${ }^{558}$ Roger CHARTIER, op.cit., p. 17.

${ }^{559}$ Para Ricoeur o entrecruzamento entre a história e a ficção se dá na tentativa de refiguração do tempo.
} 
compaixão ou até do apelo ao perdão". ${ }^{560}$ Neste entrecruzamento, tais acontecimentos têm o poder de fundar ou reforçar uma identidade de comunidade e de narrativa desta e de seus membros. ${ }^{561}$ Um evento histórico como a Independência certamente se enquadra neste aspecto, e mobiliza os mais variados sentimentos na comunidade social mais diretamente relacionada a ela.

Acompanhamos nesta pesquisa que há uma marginalização de histórias que compõem o processo de Independência e cada vez mais sofrem certa obliteração (podendo ser verificada em livros de ensino básico ou mesmo na quantidade de pesquisas produzidas) a exemplo da revolução de Pernambuco de 1817 e das lutas de Independência na Bahia. Evidencia-se a preponderância da uma versão, também oficial, da Independência centralizada no Sudeste. Com isso, é possível questionar a produção de narrativas e da memória coletiva.

Maria de Lourdes Viana Lyra analisa a escrita de memórias da Independência, a definição de seus marcos comemorativos e a versão oficial que passou para os livros de ensino, e a produção de monumentos da história. Há que se lembrar então, dos relatos das testemunhas oculares da declaração de Independência: Padre Belchior, publicado em 1826, e relatos publicados na década de 1860 do Tenente Canto e Mello e Coronel Marcondes ${ }^{562}$, além da História dos Principais sucessos do Império do Brasil, escrita por José da Silva Lisboa, o Visconde de Cairu, publicada entre 1827 e 1830, produzida justamente para concretizar essa memória “oficial” do ato fundador do Estado brasileiro e separação de Portugal. ${ }^{563} \mathrm{O}$ argumento da autora é que no período mesmo da Independência, o 07 de setembro não possuía esse reconhecimento como a data que inaugura o Brasil Independente. Foi a partir dos escritos acima citados que esse marco foi se construindo e consolidando. Além disso, a partir da Independência, os intelectuais e literatos se preocuparam com a busca de identidade e herança brasileiras, com os

\footnotetext{
560 Paul RICOEUR, “O entrecruzamento da história e da ficção”. In: Tempo e narrativa-Tomo III. Campinas, SP: Papirus, 1997, p.324.

${ }^{561}$ Ibidem, p. 324. Na ficção abre-se um campo para o "vir a ser”, onde o possível pode ser retomado.

${ }^{562}$ Para mais detalhes sobre a criação dos marcos e memória da Independência verificar artigo de Maria de Lourdes Viana LYRA, "Memória da Independência: Marcos e representações Simbólicas". In: Revista Brasileira de História, volume 15, n 29. São Paulo, 1995, p.173-206.E livro paradidático escrito por Cecília Helena de Salles OLIVEIRA. 7 de setembro de 1822: Independência e memória nacional, Série Lazuli Rupturas. São Paulo: Companhia Editora Nacional, 2005.

${ }^{563}$ Ibidem. O artigo de Maria de Lourdes Viana Lyra e publicação de Cecília Helena problematizam a definição deste marco do 07 de setembro e baseadas nos discursos de cartas, documentos oficiais e publicações de intelectuais em periódicos da época, mostram como foi se definindo esta data comemorativa, e que as primeiras versões da história oficial, publicada por Padre Belchior e por José da Silva Lisboa, Visconde de Cairu, consolidaram esta versão de apoio a D. Pedro de forma heroicizante, porém silenciando a tensão política e social em torno da decisão pela separação de Independência do Brasil de Portugal.
} 
movimentos Indianista e Romantismo. História e literatura andaram lado a lado com a definição de marcos oficiais nacionais e regionais, e na produção da memória relativa à Independência do Brasil.

A participação dos intelectuais no processo de Independência e formação dos estados nacionais se destacou pela importância na difusão de pensamento e das experiências políticas inovadoras e revolucionárias, através de sua atuação na escrita de periódicos e na difusão de conceitos utilizados e significados que tinham na época. No aspecto da consolidação e busca de uma identidade nacional, os intelectuais e a literatura com o Romantismo tiveram ainda maior importância, como explicado acima.

Cecília Helena Oliveira, em sua análise do quadro de Pedro Américo, que imortalizaria a imagem de D. Pedro no momento da declaração da Independência, levanta questões sobre a relação da história, a construção da memória e dimensão política que engendram a sociedade de forma muitas vezes conflitiva. Esses aspectos influenciaram na concepção do quadro pelo artista e foram passados através desta representação para a memória oficial da história do Brasil. A autora ressalta:

Transcorrido tanto tempo, do movimento de lutas políticas da década de 1820 e dos inúmeros e contraditórios significados atribuídos à Independência durante o século XIX pareciam ter resistido apenas um episódio reificado e protagonistas metamorfoseados em personagens de uma cena dramática, fragmento retirado do imenso quadro de eventos que se supunha ser a história, ao qual se atribuía o caráter de divisor de águas e o poder de instaurar a nação e a nacionalidade. ${ }^{564}$

Hendrik Kraay, em artigo publicado em 2010 565 , discorda de Maria Lyra, e argumenta que os periódicos e decretos de 1823 já indicavam comemorações no 7 de setembro, entretanto não havia um consenso em torno da data. $\mathrm{O}$ autor argumenta que o 12 de outubro, data da aclamação do Império e aniversário de D. Pedro I, também era celebrado com pompa. Basicamente, através de fontes dos anos subsequentes a 1822, segundo Hendrik Kraay, muitas datas foram decretadas e debatidas para comemorações

\footnotetext{
564 Cecília Helena de Salles OLIVEIRA. "O Brado do Ipiranga: Apontamentos sobre a Obra de Pedro Américo e a Configuração da Memória da Independência". In: Cecilia Helena de Salles OLIVEIRA; Claudia Valladão de MATTOS(orgs.). O Brado do Ipiranga. São Paulo: EDUSP: Museu Paulista da Universidade de São Paulo, 1999. P.74-75.

${ }^{565}$ Hendrik KRAAY, “A Invenção do Sete de Setembro, 1822-1831. In: Almanack Braziliense. São Paulo, $\mathrm{n}^{\circ} 11$, p.52-61, mai.2010.
} 
cívicas como marcos da Independência, mas em geral elas orbitavam entre a abertura da Constituinte nacional (25 de março), e o dia do Fico (9 de janeiro). Quando D. Pedro abdicou, então a data de 12 de outubro (que também é a data de aniversário do Imperador) é rechaçada como comemoração, mas o 7 de Setembro permaneceu, ao menos no Rio de Janeiro. Embora, variando as intituições de datas cívicas, desde 1823 o 7 de setembro já era reconhecido, é o que o Kraay argumenta. Quando se refere à Bahia, cita uma aclamação $^{566}$ feita por Ladislau dos Santos Titara, o autor de Paraguassú (1835 e 1837), recitada em noite de gala em 7 de setembro de 1828, recebendo muitos aplausos sendo interpretado como o reconhecimento da data. Entretanto, o autor ressalta que os baianos estavam "profundamente envolvidos na celebração do 2 de julho de 1823 , quando as tropas portuguesas evacuaram Salvador, empenhando-se para transformar tal data em dia de festividade nacional." $" 567$

Neste ponto, encontramos uma disputa de celebrações. O 2 de julho foi transformado em feriado estadual na Bahia. Todavia, nas comemorações do primeiro centenário da Independência, em 1922, conforme Gerson Ledezma explica, houve um grande engajamento para as celebrações do 7 de setembro por parte do presidente Epitácio Pessoa. Mas foi o 2 de julho de 1923, que completaria o primeiro centenário da expulsão das tropas de Portugal da Bahia, que teve adesão massiva da população nas comemorações. Dessa forma, foi possível perceber uma disputa de memória das celebrações dos marcos nacionais em torno da Independência, pois embora a data comemorativa nacional seja o 7 de setembro, o 2 de julho é considerado o marco da Independência (que virou a independência da Bahia) devido à expulsão das tropas lusas do território brasileiro. De acordo com Ledezma, na imprensa do período foram amplas as manifestações que demonstravam a pouco importância e apreço às comemorações do 07 de Setembro na Bahia, e que, em contraste o 2 de Julho representava a verdadeira Independência. ${ }^{568}$

Em outro aspecto, já não de disputa de uma memória, mas de uma obliteração de um capítulo do processo de Independência e de um projeto alternativo ao nacional, citamos a Revolução de Pernambuco de 1817. Não ignoramos o peso mercadológico para a produção de certos tipos de obras literárias, e no escopo de escolha dos objetos

\footnotetext{
566 Trata-se da "Congratulação aos brasileiros", em que Ladislau dos Santos Titara enaltece os feitos de D. Pedro I e o Sete de setembro. Em: Hendrik KRAAY, op.cit., mai.2010.

${ }^{567}$ Hendrik KRAAY, op.cit., p.61.

${ }^{568}$ Gerson LEDEZMA, op.cit, p.69-87.
} 
analisados tentamos fugir a essa tendência verificada em produções analisadas já no artigo sobre a cultura de história ${ }^{569}$. Mas questionamos se a publicação de obras que resgatem a memória da Revolução pernambucana, por exemplo, já não seria indicativa dessa obliteração ou ofuscamento da história?

Foi possível verificar ao longo da dissertação, tendo como uma categoria de análise condutora a cultura de história, um movimento sincrônico e diacrônico de aspectos das representações da história da Independência na literatura brasileira. Acreditoque, algumas vezes mesmo que inconscientemente, outras propositalmente, muitas inquietações que pairam na sociedade e dialogam com a história, são refletidas na literatura. Varnhagen em sua História Geral do Brasil, discorreu que preferia deixar de fora a história da revolução de Pernambuco, e como apresentado em artigo por Thamara Rodrigues, em comparação com a Inconfidência Mineira há uma "marginalização" atual da revolução de 1817 de Pernambuco ${ }^{570}$. A autora levanta algumas possibilidades para o que ora chama de "esquecimento", ora de "marginalização" da história do evento: as disputas historiográficas em torno da Revolução; uma hegemonia política do Sudeste; também questiona a preponderância de Pernambuco visto que Paraíba, Ceará, Rio Grande do Norte e Alagoas tiveram atuação expressiva no movimento. ${ }^{571}$

Porém, não foi apenas Varnhagen que tratou de maneira pejorativa a revolução de Pernambuco de 1817, Euclides da Cunha também procedeu da mesma maneira. De acordo com o escritor, o movimento revolucionário de Pernambuco de 1817 "à parte as causas secundárias e imediatas da indisciplina militar, estampando o rótulo de falso das agitações nacionais, tinha origens profundas"572. Segundo Euclides da Cunha, "Domingos Theotônio Jorge e Barros Lima, apelidado como o "Leão Coroado", agiam, [como] heróis autômatos, sob impulso incoercível das tendências nativistas, sob o disfarce republicano..."573

É interessante perceber que há uma tentativa de rebaixar a importância do evento o depreciando, assim como seus líderes e participantes. Entretanto, o simples fato de citar a Revolução de Pernambuco de 1817, pois não era possível ignorá-la na história do Brasil

\footnotetext{
569 João Paulo PIMENTA [et.al.], op.cit, 2014.

570 Thamara de Oliveira RODRIGUES, op.cit., p.290.Há um trabalho em andamento que se debruça sobre a historiografia da Revolução de Pernambuco de 1817: Breno Gontijo ANDRADE, DUZENTOS ANOS DE 1817: produção historiográfica sobre a Revolução Pernambucana. Tese de doutorado (em andamento). Universidade Federal de Minas Gerais (UFMG).

${ }^{571}$ Ibidem, op.cit., p. 290.

572 Euclides da CUNHA, "Da Independência à República”. In: À margem da História. São Paulo: Editora UNESP, 2019, p.280.

573 Ibidem, p. 280.
} 
no período, sua disseminação nas províncias do atual Nordeste (Norte na época) e a dura repressão que sofreu, já denotam sua importância por mais que a intenção dos historiadores/escritores fosse contrária.

De maneira distinta Oliveira Lima se destaca, pois defende e ressalta a revolução de Pernambuco, de modo contrário a Varnhagen e Euclides da Cunha. O autor aponta que a "revolução de 1817 de Pernambuco fundara uma república assaz bem organizada." ${ }^{574}$ É importante salientar que Oliveira Lima era pernambucano, e como foi possível perceber nessa dissertação, é um fator relevante para esse posicionamento distinto dos outros autores, da mesma forma que foi verificado com os escritores (a) das obras literárias aqui analisadas.

Mariana dos Santos Ribeiro aponta na mesma direção que Thamara Rodrigues, comparando as figuras de Tiradentes e Frei Caneca, através de análise da produção historiográfica do século XIX . A pesquisadora ressalta que o nome de Frei Caneca "não se destacou na construção simbólica da questão republicana em fins do século XIX, o que deu a Tiradentes e à Inconfidência Mineira uma superdimensão nos principais livros didáticos que persiste ainda hoje". ${ }^{575}$ Sabemos que a repressão ao movimento de 1817 foi severo, os líderes foram condenos à morte por crime de lesa-majestade, esquartejados e partes dos corpos foram expostas nas províncias de forma "pedagógica" para que insurgentes testemunhassem o que acontecia com aqueles se levantavam contra a monarquia, o que demonstra a importância do movimento no século XIX. Ora, nas obras literárias que abordam a Independência de uma forma abrangente, que consideramos representar uma visão processual, a revolução de Pernambuco de 1817 era abordada, e essa dimensão da importância do movimento evidenciada, inclusive através da exposição da dura reação da Coroa. Em Olhos Negros (2009), por exemplo, na voz da narradora foi possível identificar uma crítica ao ensino sobre a história da Revolução Pernambucana, como já mencionada. ${ }^{576}$ Esse ofuscamento ocorreu gradualmente, e foi possível perceber

\footnotetext{
${ }^{574}$ Manuel de Oliveira LIMA, Formação histórica da nacionalidade brasileira. $3^{\mathrm{a}}$ edição. Rio de Janeiro: Topbooks. São Paulo: Publifolha, 2000, p.142.

${ }^{575}$ Mariana dos Santos RIBEIRO, "Frei Caneca e a Confederação do Equador". In: Revista Intellèctus, v.5, n.2, 2006, p.3. Sobre a questão a autora indica: José Murilo de CARVALHO, "Tiradentes: um herói para a República”. In: A formação das almas: o imaginário da República no Brasil. São Paulo: Cia das Letras, 1990.

${ }^{576}$ A citação com a crítica ao ensino encontra-se na Introdução dessa dissertação, no item 1.2, parte em que apresento cada uma das obras literárias que compõem o corpus dessa pesquisa. Em suma é apontado um reverenciamento á figura de Frei Caneca e mitificação de José de Barros Lima, e esquecimento do padre João Ribeiro e José Tenório. Em:Maria Cristina C. ALBUQUERQUE, op.cit., p.267.
} 
esse movimento também nas obras literárias aqui analisadas, como um reflexo e componente dessa cultura de história.

Assim, o que se percebe é a já conhecida preponderância de uma narrativa da memória da Independência, concentrada em eventos do Sudeste. Essa versão "ofícial" permaneceu sem muitas alterações, embora sofrendo interpretações distintas ao longo do tempo. Os eventos do projeto alternativo de Pernambuco de 1817, e do marco da Independência da Bahia no 02 de julho, à excessão dos próprios estados e região Nordeste que ressaltam os eventos, foram perdendo importância em uma narrativa nacional, ganhando destaque regionalmente. Foi possível perceber nas obras literárias aqui estudadas, a partir do século XX, que os autores de regiões do Nordeste abordaram ou citaram os eventos, como o Cordel da história da Independência (2008), Viva o povo brasileiro (1984), e os dois romances sobre a revolução Pernambucana Olhos Negros (2009) e A noiva da revolução (2006). Apenas Murilo Mendes, natural de Minas Gerais, com a obra História do Brasil (1932), fez um poema sobre o movimento pernambucano. A abordagem pelas obras literárias é indicativa do movimento desse ofuscamento, dado o recorte necessário para a pesquisa, reconhecendo que podem existir outras que contradigam o argumento. Entretanto, embora indicativo, o argumento ganha força se somado aos artigos das pesquisadoras Thamara Rodrigues ${ }^{577}$ e Mariana dos Santos Ribeiro $^{578}$.

Em suma, neste capítulo acompanhamos muitos temas que não apenas se conectam, mas são caros aos estudos da Independência do Brasil e projetam muitas imagens sobre o país. Foi ressaltada a importância do exame dos representantes das vozes (dos grupos) que configuram visões e projetos distintos do Brasil e do futuro almejado. Dessa maneira, salientando as muitas leituras que as obras podem ter e a importância do repertório dos leitores para entendimento, conexões e interpretações das representações da história contidas nelas, se delineiam as incontáveis combinações e imagens do Brasil, como em um caleidoscópio.

\footnotetext{
577 Thamara Rodrigues, op.cit., 2017.

${ }^{578}$ Mariana dos Santos RIBEIRO, op.cit., 2006.
} 


\section{Considerações Finais}

A partir da análise aqui apresentada, é possível inferir um balanço. As obras ficcionais selecionadas, produzidas no século XIX e começo do XX, possuem um caráter sincrônico, refletindo preocupações de seu tempo. Sobretudo nos poemas épicos, foi possível perceber uma visão da Independência enquanto processo, em que se traça a partir da Revolução Francesa inúmeros eventos até a declaração da Independência, não se esgotando a narrativa nesse ponto mas vislumbrando partes da história do Primeiro Império, algumas vezes avançando até a abdicação de D. Pedro I. As lutas nas províncias de Norte e Sul do Brasil não perdem em importância nesses épicos, sendo destacada em alguns deles, inclusive, a Inconfidência Mineira e seus ideais supostamente liberais como já pairando no território.

A partir do século XX, percebemos o aspecto diacrônico dessa produção, em que pouco se renovou em termos de percepção da história e memória da Independência. Aliás, o que ficou estanque foram as abordagens produzidas tanto pelo Estado, em termos de construção da memória e comemorações cívicas da Indepedência, quanto as interpretações produzidas pelos historiadores ainda no século XIX. O que se tornou notável foi o tratamento cômico e jocoso a partir do século XX, em torno dessa história. No século XIX muito se trabalhou em torno da memória louvável e atuação de alguns personagens, em geral, da Família Real e conselheiros, inclusive com uma construção heróica em torno da figura de D. Pedro, sobretudo. A partir do século XX, há um estranhamento e distanciamento dessa versão, com tratamento inverso, como uma forma de rebaixamento da realeza, do herói e dessa narrativa. Uma obra que marca de forma contundente, principalmente as representações biográficas de Carlota Joaquina e D. João VI, é o livro de Manuel de Oliveira Lima, D. João VI no Brasil (1908). Aliás, não apenas dos dois personagens, mas também do período Joanino. Entretanto, sobre o aspecto dos costumes do período, muito do que está presente na obra de Oliveira Lima publicada em 1908, já aparecia no folhetim de Manuel Antonio de Almeida, Memórias de um sargento de milícias (1852-1853) e de Machado de Assis, Memórias Póstumas de Brás Cubas (1880).

No recorte das obras aqui analisadas, portanto, a quebra do tom elevado ou uma abordagem jocosa aparece primeiro na História ou Literatura? Considerando o caráter híbrido da escrita da história do período, em que homens de Belas Letras produziam estes estudos, o tom rebaixado no tratamento dos personagens apareceu primeiro em Oliveira 
Lima, que escreveu sua obra baseado nos relatos de Laura Junot. As descrições produzidas pelo autor em seu livro, que teve vasta pesquisa e acesso a diversos documentos, visto que era diplomata, é reafirmada e replicada até os dias atuais na literatura (e pode-se dizer em outros meios culturais tais como séries de televisão e conteúdo da internet e filmes). Assim, os perfis produzidos por Oliveira Lima em sua obra, foram apropriados e utilizados na produção de um tipo de caracterização jocosa dos personagens, tais quais caricaturas, que ganharam amplamente adesão pública e social, tornando-se marca forte e estável, consagradas nas representações da Independência e dessa cultura de história.

A respeito de uma abordagem e entendimento processual da Independência, parece, e esta é uma conclusão indicativa, que houve uma quebra. Talvez, inclusive por conta do peso da historiografia do século XIX que destacava a atuação de D. Pedro e a manutenção da monarquia no Brasil, e do ensino da história. Assim, foi possível perceber que as lutas que ocorreram no período perderam importância no processo, ganhando certa marginalização ou ofuscamento. Em geral, a história das lutas com projetos alternativos, como o caso de Pernambuco e das lutas da Independência na Bahia aqui estudados, são lembrados e valorizados por escritores da região Nordeste. Parece que hoje a revolução de Pernambuco de 1817 é vista como episódio isolado, assim como as lutas que ocorreram na Bahia entre 1822 e 1823. Caberia portanto, investigação aprofundada nessa questão.

As representações da Independência variaram muito de acordo com cada obra, algumas com abordagem mais fragmentada, episódica, as do século XIX apresentando o que pode ser entendido como um processo e sem ressaltar maior relevância a alguma região do país. Para os escritores dos épicos, os motins, insurgências, revoltas, ganhavam relevância pois indicavam as insatisfações e a quebra de unidade do território.

O desenvolvimento sobre a abordagem da história, em termos de passado, presente e futuro foi interessante, e neste aspecto, as percepções se mostraram muito influenciadas pelo presente das obras, avaliando o momento de publicação de cada uma. Assim, foi possível perceber as contaminações e entrecruzamentos entre história e literatura, entre história e ficção, e a importância de ambos no movimento de nossa cultura de história, apresentando ideias, inquietações, reiterações e tímidas transformações nas representações da Independência e concepções da história. De toda forma, se mostrou elemento relevante para, numa análise de longo prazo, perceber como se pensa e se representa a história já não de um ponto de vista exclusivamente acadêmico, mas mais próximo da sociedade e de imaginários e sensos comuns. Também foi possível perceber 
de uma forma que pode ser inconsciente ou não, através de intertextualidades e da própria cultura de história, que a historiografia e o trabalho do historiador se refletem na literatura e no pensar histórico na sociedade. Um ponto muito importante nessa relação são os leitores e seu repertório, e as leituras que realizam.

Foi possível identificar ainda, como já apontado, um movimento contínuo da cultura de história, não diria que circular mas em espiral pelo fato de que podem ocorrer transformações nessa cultura. Entretanto, como se trata da história, o que ficou claro na análise, é que certas concepções se tornaram muito tradicionais, já permeando um imaginário social da história de forma sólida, muito estável - o senso comum. Assim, as representações da história feitas na literatura e outros suportes culturais acabam por reafirmar certas imagens e noções. As transformações, embora possíveis, ocorrem de forma muito lenta, são muito tímidas.

Dois casos exemplares são a retórica da recolonização, e as caracterizações e representações de três personagens: D. João e Carlota Joaquina - normalmente retratados de forma conjunta- e D. Pedro. Embora a historiografia tenha avançado, descontruindo a teoria da recolonização como visto em Antonio Penalves ${ }^{579}$, essa é uma ideia ainda difundida de forma ampla. As caracterizações dos personagens se pautam de maneira recorrente e categórica na obra de Oliveira Lima, e são apenas reafirmadas. Foram encontradas sempre as mesmas descrições, o mesmo tipo de abordagem dos personagens, a utilização, inclusive, dos mesmos adjetivos nas referências a eles. Essas representações não se alteraram.

O tema da Independência se apresentou especialmente proveitoso num estudo dessa envergadura, como proposto numa análise de longa duração, observando gêneros literários diversificados e a historiografia, pois apresenta muitas nuances sobre o Brasil. Aqui se projeta a imagem do caleidoscópio, que possui algumas definições, mas em suma se compõe por múltiplos fragmentos de vidros coloridos que ao se movimentarem produzem combinações diversas pelo reflexo dos vidros, formando imagens variadas. São muitos fragmentos que compõem a história da Independência e do Brasil, que podem ser combinados de muitas maneiras. Além dos possíveis recortes que compõem esses fragmentos ressalto o papel do leitor. Acredito que na dissertação tenha ficado claro que tratei de muitos tempos na pesquisa, e aqui me refiro não apenas ao recorte cronológico de longa duração e conexão com uma cultura de história, mas às muitas leituras e leitores.

${ }^{579}$ Antonio Rocha PENALVES, op.cit., 2009. 
E nesse ponto, destaca-se o tempo do leitor e da leitura, não se trata apenas de públicos leitores diversificados, mas também sobre o fato de que um leitor pode fazer muitas leituras de uma mesma obra, e essa variação das leituras, como já apontado, depende do repertório desse leitor. Temos, portanto, a tessitura de muitos tempos, muitas representações e muitas narrativas da história da Independência e seus personagens se entrelaçando. Assim, a projeção da imagem do caleidoscópio se amplia, pois além dos múltiplos fragmentos de temas e aspectos que podem ser abordados com o estudo da Independência e do Brasil, as diversas leituras possíveis e os muitos tempos dos leitores ajudam a ampliar as possibilidades de imagens formadas. A junção de todos esses fatores ou "fragmentos" que serão combinados ou "iluminados" de acordo com cada leitor, em cada momento, projeta dessa maneira, muitas possibilidades de combinações e consequentes imagens do Brasil.

Nessa pesquisa tratei da política, da sociedade, da cultura, de projetos de Brasil, de ideias e imagens de nação e do brasileiro, de muitos conceitos que ganharam sentidos distintos ao longo do tempo e de acordo com quem o empregava. E pela temática e objetos analisados, também abordei sobre leituras, sobre a memória nacional, sobre a escrita da história e ainda, sobre o ensino de história.

Como já apontado, são muitas nuances que combinadas formam muitas imagens do Brasil.

Assim, finalizo, discorrendo sobre as dificuldades na pesquisa, encontradas devido o recorte amplo, a variedade de gêneros e obras literárias e a longa duração. "Representações da Independência", se mostrou um recorte muito abrangente, pois como foi possível acompanhar na dissertação, fornece abertura para o estudo de muitos temas e configurações possíveis da Independência: o processo político, personagens, identidades políticas, escravidão, relações comerciais, cultura, costumes e tradições no Brasil do período, concepções de História e de memória, entre muitas outras abordagens possíveis que poderiam ser feitas ou aprofundadas. Destaco que essa investigação se apresenta como um feixe que ilumina um segmento de estudos da Independência que podem ser aprofundados em outras pesquisas, de forma interdisciplinar entre História e Literatura. Ao fim, diria, que cada uma das obras aqui tratadas individual e conjuntamente, renderia uma dissertação em si mesma. Mas o que caracteriza, em suma, esta dissertação, é a análise em conjunto conectando História, Literatura e cultura de história na longa duração, com um olhar voltado também para a historiografia. O resultado acaba por produzir uma análise algo superficial das obras. A amplitude desta 
pesquisa, assim, tenta contribuir para iluminar um campo produtivo para aprofundar possíveis estudos sobre a história da Independência e do Brasil tendo como objeto de investigação a literatura e escritores de obras literárias, numa abordagem multidisciplinar. 


\section{Fontes}

- ALBUQUERQUE, Maria Cristina Cavalcanti Albuquerque. Olhos negros - O romance de 1817. $3^{\mathrm{a}}$ edição. Recife: Bagaço Editora, 2017.

- ALMEIDA, Manuel Antônio de. Memórias de um sargento de milícias. São Paulo: Penguin Classics: Companhia das Letras, 2013. Primeira edição com prefácio de Ruy Castro. Originalmente publicado em folhetim entre 1852-1853.

- ASSIS, Machado de. Memórias Póstumas de Brás Cubas. São Paulo: Penguin: Companhia das Letras, 2014. Originalmente publicado a partir de março de 1880, na Revista Brasileira, a primeira versão em livro foi lançada em 1881.

-BRAGA, Medeiros. O cordel da história da Independência, Paraíba, janeiro/2008. Não possui dados de editora sugerindo produção independente. Será consultada a versão original disponível online na Cordelteca, no endereço eletrônico abaixo:

http://docvirt.com/docreader.net/DocReader.aspx bib=Cordel $\&$ PagFis=87607\&Pesq=

-CASTRO, Ruy. Era no tempo do rei: um romance da chegada da corte. São Paulo: Alfaguara: Objetiva, 2007.

-MENDES, Murilo. História do Brasil (1932). PICCHIO, Luciana Stegagno (org., introdução e notas). Rio de Janeiro: Nova Fronteira, 1991. A obra apresenta poemas sobre eventos marcantes da história do Brasil, e foi publicada em 1932. Os poemas selecionados são: "Embarque do papagaio real"; "A mão de Domingos José Martins"; "Relíquias de Frei Caneca"; "Fico"; "Preparativos da Pescaria"; "Serenata da Dependência" e "A pescaria".

- OLIVEIRA, Paulo Santos de. A noiva da revolução: o romance da república de 1817. Recife: Associação Centro Vivo Recife, 4a edição, 2014. Publicado originalmente em 2006.

-PINHEIRO, Joaquim Gil. Primícias. Poema dos pincipaes factos da história do Brasil até sua independência. São Paulo: (não consta tipografia), 1900.

-RIBEIRO, João Ubaldo. Viva o povo brasileiro (edição especial de 30 anos). São Paulo: Alfaguara: Objetiva, 2014. Obra publicada originalmente em 1984.

-TEIXEIRA E SOUSA, Antonio Gonsalves. Independência do Brasil. Poema Épico em XII Cantos, Tomo Primeiro. Rio de Janeiro: Typ. Imparcial. De Francisco de Paula Brito, 1847. E: TEIXEIRA E SOUSA, Antonio Gonsalves. Independência do Brasil. Poema Épico em XII Cantos, Tomo Segundo. Rio de Janeiro: Emp. Typ. Dous de Dezembro de P. Brito, 1855. 
-TITARA, Ladislau dos Santos. Paraguassú: epopeia da Guerra da Independência na Bahia. São Paulo: Empresa Gráfica da Revista dos Tribunais, 1973. Publicado originalmente em dois tomos em 1835 e 1837.

-TORERO, José Roberto. Galantes memórias e admiráveis aventuras do virtuoso conselheiro Gomes, o Chalaça. São Paulo: Companhia das Letras, 1994. 


\section{Bibliografia}

ABREU E LIMA, José Ignácio, Compendio da História do Brasil, Tomo I. Rio de Janeiro: Casa dos Editores Eduardo e Henrique Laemmert, 1843.

ABREU, Márcia. Histórias de cordéis e folhetos. Campinas: Mercado de Letras, 1999.

ADELMAN, Jeremy. "An Age of Imperial Revolutions". American Historical Review, v.113, n.2, april, 2008, p.319-340.

ÁLVAREZ; Sebástian Vargas. "La literatura como trabajo de memoria: disputas por la definición de pásados conflictivos en dos obras de ficción"; in: Revista História e historiografia. Ouro Preto, n.17, abril/2015, p.153-170.

ALTAMIRANO, Carlos e SARLO, Beatriz. Literatura/Sociedad. Buenos Aires:Hachette, 1983.

AMARAL, Braz do. História da Independência na Bahia. $2^{\mathrm{a}}$ ed. Salvador: Livraria Progresso editora, 1957.

AMARAL, Breno F. de. A Guerra da Independência da Bahia: 1823. São Paulo: M. Lobato, 1923.

ANDERSON, Benedict. Comunidades Imaginadas: reflexões sobre a origem e difusão do nacionalismo. São Paulo: Companhia das Letras, 2008.

ARMITAGE, David. \& SUBRAHMANYAM, Sanjay. The Age of Revolutions in Global Context c.1760-1840. London: Palgrave, 2010.

ARAUJO, Valdei Lopes. "Formas de ler e aprender com a história no Brasil Joanino". Acervo, v.22, $\mathrm{n}^{\mathrm{o}}$ 1, jan/jun 2009, p.85-98.

ARRIGUCCI, Davi. "Fragmento sobre a crônica". In: Enigma e comentário. São Paulo: Companhia das letras, 1987, p. 51-66.

AUERBACH, Erich. Mimesis: a representação da realidade na literatura ocidental. São Paulo: Perspectiva, 2011.

AZEKA, Gabriela Hatsue Yuasa. Um enjeitado e um sargento de milícias: formação do indivíduo e do romance. Tese de Doutorado. Faculdade de Filosofia, Letras e Ciências Humanas (USP), São Paulo, 2006.

AZEVEDO, Francisca L. Nogueira de. Carlota Joaquina na corte do Brasil. Rio de Janeiro: civilização Brasileira, 2003.

BARATA, Mário, "Manuscrito inédito de Lebreton. Sobre o estabelecimento de dupla escola de artes no Rio de Janeiro, em 1816". Revista do SPHAN, Rio de Janeiro, n. 14, p. 283-307, 1959. 
BASTOS, Aureliano Cândido Tavares. Os males do presente e as esperanças do futuro. São Paulo-Rio de Janeiro: Nacional 1939.

BERBEL, Márcia Regina. A nação como artefato: deputados do Brasil nas cortes portuguesas (1821-1822). São Paulo: Hucitec:Fapesp, 1999.

. "Pátria e patriotas em Pernambuco (1817-1822): Nação, identidade

e vocabulário político. In: Jancsó, István. (Org.). Brasil: formação do Estado e da nação.

São Paulo: EDUSP: Hucitec, 2003, p.345-363.

"A retórica da recolonização". In: István Jancsó. (Org.).

Independência: História e Historiografia. São Paulo: Hucitec, 2005, p. 791-808.

BERNARDES, Denis Antônio de Mendonça. O Patriotismo Constitucional: Pernambuco, 1820-1822. Tese de Doutorado. Faculdade de Filosofia, Letras e Ciências Humanas (USP), São Paulo, 2001.

BOSI, Alfredo. História concisa da Literatura brasileira, 3 ed. São Paulo: Cultrix, 1989. . "Situação e forma do conto brasileiro contemporâneo". In: O conto brasileiro contemporâneo. São Paulo: Cultrix, 2002.

. "Imagens do romantismo no Brasil”. In: GUINSBURG, Jaco (org.). $O$ romantismo. São Paulo: Perspectiva, 2008.

Entre a literatura e a história. São Paulo: Editora 34, 2013.

BRITO, Aquilino José de BRITO, "Maxixe: Dança e Música na Circularidade Cultural Brasileira”. XXVII Simpósio Nacional de História\NPUH: Conhecimento histórico e diálogo social. Natal- RN, 22 a 26 de julho de 2013.

CALLARI, Cláudia Regina. “Os Institutos Históricos: do Patronato de D. Pedro II à construção do Tiradentes”. Revista brasileira de História, São Paulo, v. 21, n. 40, 2001, p. 59-82.

CAMPOS, Padre Joaquim Pinto dos, Vida do grande cidadão brazileiro Luiz Alves de Lima e Silva: barão, conde, marquez, duque de Caxias, desde o seu nascimento em 1808 a 1878. Lisboa: Imprensa Oficial, 1878

CANDIDO, Antonio. Formação da literatura brasileira. Momentos decisivos 17501880. Rio de Janeiro: Ouro sobre azul, 2006.

"Dialética da Malandragem". Revista do Instituto de Estudos

Brasileiros, São Paulo, n. 8, p. 67-89, june 1970.

. "A literatura e a formação do homem", in: Textos de Intervenção.

São Paulo: Livraria Duas Cidades: Editora 34, 2002. 
. "O direito à literatura", in: Vários escritos. 5a ed. Rio de Janeiro:

Duas cidades: Ouro sobre Azul, 2011.

. "Esquema de Machado de Assis". In: Vários escritos. São Paulo:

Duas Cidades, 1970, p.15-32.

Literatura e Sociedade. São Paulo: Companhia Editora Nacional,

1985.

CANDIDO, Antonio e CASTELLO, José Aderaldo; Presença da literatura BrasileiraHistória e Antologia. São Paulo: Difusão Europeia do Livro, 1964.

CARVALHO, José Murilo. A construção da ordem: a elite política imperial. Teatro das sombras: a política imperial. Rio de Janeiro: Civilização Brasileira, 2008.

. Os bestializados: o Rio de Janeiro e a República que não foi.

São Paulo: Companhia das Letras, 2004.

CARVALHO, Ricardo Souza de, "Oliveira Lima entre a história e a literatura”. In: Belle Époque: crítica, arte e cultura. Rio de Janeiro: LABELLE, São Paulo: Intermeios:Fapesp, 2016, p.85-101.

CASCUDO, Luis da Câmara. Literatura oral no Brasil. Belo Horizonte: Itatiaia/ São Paulo: Edusp, 1984.

CAVIGNAC, Julie. A literatura de cordel no Nordeste do Brasil. Da história escrita ao relato oral. Natal: EDUFRN, 2006.

CERQUEIRA, Larissa Agostini. "As contibuições do Modernismo para a Literatura e a Crítica Brasileiras". In: Em Tese, [S.1], v.16, p.24-35, ago. 2010.

CHARTIER, Roger. A história cultural entre práticas e representações. Trad. GALHARDO, Maria Manuela. Lisboa: Difel; Rio de Janeiro: Editora Bertrand Brasil, 1988.

. “O romance: da redação à leitura". In: Do palco à página. Rio de

Janeiro: Casa da Palavra, 2002.

CHAUVIN, Jean Pierre. O poder pelo avesso: mandonismo, dominação e impotência em três episódios da literatura brasileira. Tese de Doutorado. Faculdade de Filosofia, Letras e Ciências Humanas (USP). São Paulo, 2006.

CHIARAMONTE, José Carlos. "La formación de los Estados nacionales en Iberoamérica". Boletin del Instituto de Historia Argentina y Americana Dr. Emilio Ravignani, $3^{\mathrm{a}}$ serie, $1^{\text {o }}$ sem., p.143-165 (1997). 
- "Metamorfoses do conceito de nação durante os

séculos XVII e XVIII”, in: István JANCSÓ (org.). Brasil: formação do Estado e da nação, São Paulo, Hucitec/Fapesp/Editora Unijuí, 2003, pp. 61-91.

CHIAPINI, Ligia. "Literatura e História. Notas sobre as relações entre os estudos literários e os estudos historiográficos. In: Revista Literatura e Sociedade. São Paulo, n.5, 2000, p.18-28.

COLI, Jorge. O Corpo da liberdade: reflexões sobre a pintura do século XIX. São Paulo: Cosac Naify, 2010.

COMPAGNON, Antoine. O demônio da teoria: literatura e senso comum. MOURÃO, Cleonice Paes Barreto; SANTIAGO, Consuelo Fortes (trad.). Belo Horizonte: Ed.UFMG, 2012.

COSTA, Wilma Peres. "A independência na historiografia brasileira”, in: JANCSÓ, István (org.), Independência: História e historiografia. São Paulo: Fapesp: Hucitec, 2000, p.53-118.

CUNHA, Euclides da. À margem da história. São Paulo: Editora UNESP, 2019.

CURRAN, Mark. História do Brasil em cordel. São Paulo: Edusp, 2001.

DIAS, Elaine, "Correspondências entre Joachim Le Breton e a corte portuguesa na Europa: o nascimento da Missão Artística de 1816”. Anais do Museu Paulista, São Paulo , v. 14, n. 2, p. 301-313, Dec. 2006.

DIAS, Maria Odila Leite da Silva. A interiorização da metrópole e outros estudos. São Paulo: Alameda, 2005.

DIEHL; Astor Antônio. Cultura historiográfica: memória, identidade e representação. Bauru, SP: EDUSC, 2002.

DORATIOTO, Francisco, Maldita Guerra: nova história da Guerra do Paraguai. São Paulo: Companhia das Letras, 2007.

ECO, Umberto. Seis passeios pelos bosques da ficção. FEIST, Hildegard (trad.). São Paulo: Companhia das Letras, 1994. . Sobre a literatura. Rio de Janeiro: Record, 2003.

. Obra Aberta: forma e indeterminações nas poéticas contemporâneas.

CUTOLO, Giovanni (trad.). São Paulo: Perspectiva, 2008.

Lector in fabula: a cooperação interpretativa nos textos narrativos.

CANCIAN, Attílio (tradução). São Paulo: Perspectiva, 2011.

EFEGÊ, Jota. Maxixe - A dança excomungada. Rio de Janeiro: Conquista, 1974. 
FALCON, Francisco J, Calazans. "História e representação". In: Revista de História das Ideias, vol 21, Coimbra, 2000, p.87-126.

FANNI, Rafael. Temporalização dos discursos políticos no processo de Independência do Brasil (1820-1822). Dissertação de Mestrado. Faculdade de Filosofia, Letras e Ciências Humanas (USP). São Paulo, 2015

FERNÁNDEZ SEBASTIÁN, Javier. Hacia una historia de los conceptos políticos. Diccionario político y social del mundo iberoamericano. Madrid: Fundación Carolina/Sociedad Estatal de Conmemoraciones Culturales/Centro de Estudios Políticos y Constitucionales, 2009, p. 25-45.

FERREIRA, Jerusa de Carvalho Pires. Cavalaria em Cordel: o passo das águas mortas. São Paulo: EDUSP, 2016.

FIORIN, José Luiz. "A construção da identidade nacional brasileira; in: Bakhtiniana, v.1, n.1. São Paulo, $1^{\circ}$ sem.2009, p.115-126.

FONSECA E SILVA, Maria Laura Muller da, "Entre dois mundos. O intelectual brasileiro e as experiências fora do lugar”. In: Darandina Revista eletrônica. Programa de Pós-Graduação em Letras/UFJF, volume 7, número 1.

FOUCAULT, Michel. As palavras e as coisas. São Paulo: Martins Fontes, 1987.

FRAGOSO, João Luís. Homens de grossa ventura: acumulação e hierarquia na praça mercantil do Rio de Janeiro, 1790 - 1830. Rio de Janeiro: Civilização Brasileira, 1998. FRANKLIN, Jeová. Xilogravura popular na literatura de cordel. Brasília: LGE, 2007. FREYRE, Gilberto. Casa-Grande \& Senzala: formação da família brasileira sob o regime da economia patriarcal. 51 ${ }^{\mathrm{a}}$ ed. rev. São Paulo: Global, 2006. - Sobrados e Mucambos. Decadência do patriarcado e desenvolvimento do urbano. $15^{\mathrm{a}}$ ed.rev. São Paulo: Global, 2004.

FRYE, Northrop. Anatomia da crítica. São Paulo:Cultrix, 1973.

GALVÃO, Ana Maria de Oliveira. Cordel: leitores e ouvintes. Belo Horizonte: Autêntica, 2001

FURTADO, Celso. Formação econômica do Brasil. São Paulo: Companhia das Letras, 2007.

GADAMER, Hans-Georg. Verdade e Método. MEURER, Flávio Paulo (trad.). Petrópolis: Vozes, 1997.

GLEDSON, John. Machado de Assis: impostura e Realismo. São Paulo: Companhia das Letras, 1991. 
Machado de Assis: ficção e história. COUTINHO, Sônia (tradução).

São Paulo: Paz e Terra, 2003, p.13-35.

GOMES, Maria Angela de Castro. "Cultura política e histórica no Estado Novo". In: ABREU, Martha; SOIHET, Rachel e GONTIJO, Rebeca (orgs.). Cultura política e leituras do passado: historiografia e ensino de história. Rio de Janeiro: Civilização Brasileira, 2007.

GOMES, Maria Angela de Castro. "História, historiografia y cultura politica em Brasil: algunas reflexiones". Ayer, v.2, 2008, p.115-139.

GRAHAM, Richard, “ 'Ao mesmo tempo sitiantes e sitiados'. A luta pela subsistência em Salvador (1822-1823)”. In: István JANCSÓ (org.), Independência: História e historiografia. São Paulo: Fapesp: Hucitec, 2005, p.411-445.

GRIMBERG, Keila \& SALLES, Ricardo, O Brasil imperial: 1808-1831, volume I. Rio de Janeiro: Civilização Brasileira, 2010.

GUERRA, François-Xavier. "Metamorfoses do conceito de nação durante os séculos XVII e XVIII", in: István JANCSÓ (org.). Brasil: formação do Estado e da nação, São Paulo, Hucitec/Fapesp/Editora Unijuí, 2003, pp. 61-91.

GUIMARÃES, Lucia Maria Paschoal. Debaixo da imediata proteção de Sua Majestade Imperial: o Instituto Histórico e Geográfico Brasileiro. Doutorado. São Paulo: Faculdade de Filosofia, Letras e Ciências Humanas, Universidade de São Paulo, 1994.

GUIMARÃES, Manoel Luis Lima Salgado. "Nação e Civilização nos Trópicos: O Instituto Histórico e Geográfico Brasileiro e o projeto de uma história nacional”. Estudos Históricos, $\mathrm{n}^{\circ} 1$. Rio de Janeiro, 1988, p.5-27.

HALLEWELL, Laurence. O livro no Brasil. São Paulo: T. A. Queiroz, 1995.

HOBSBAWM. Eric J. Nações e nacionalismo desde 1780: programa, mito e realidade. PAOLI, Maria Celia; QUIRINO, Anna Maria (trad.). Rio de Janeiro: Paz e Terra, 1990. A era das revoluções, 1789-1848. São Paulo: Paz e Terra, 25a edição, 2010.

HOLANDA, Sérgio Buarque de. "A herança colonial-sua desagregação". In: História Geral da civilização brasileira, tomo II: O Brasil Monárquico. Rio de Janeiro: Bertrand Brasil S. A, p.09-39, 1993.

Raízes do Brasil. Edição Comemorativa 70 anos. São Paulo:

Companhia das Letras, 1995.

ISER, Wolfgang. O ato da leitura: uma teoria do efeito estético, volume 1. São Paulo: Editora 34, 1996. 
O ato da leitura: uma teoria do efeito estético, volume 2. São Paulo:

Editora 34, 1999.

JANCSÓ, István e PIMENTA, João Paulo G. "Peças de um mosaico (ou apontamentos para o estudo da emergência da identidade nacional brasileira).” In: MOTA, Carlos G (org.). Viagem incompleta: a experiência brasileira 1500-2000. São Paulo: Senac, 2000. JANCSÓ, István. Na Bahia, contra o império: história do ensaio de sedição de 1798. São Paulo: Hucitec/Edufba, 1995. (org.). Brasil: Formação do Estado e da nação. São Páulo: Hucitec: Unujuí: FAPESP, 2003. (org.). Independência: História e historiografia, In; Jancsó, István (org.), São Paulo: Fapesp: Hucitec, 2005.

JAUSS, Hans Robert; ISER, Wolfgang; STIERLE, Karlheinz; GUMBRECHT, hans Ulrich (orgs.). A literatura e o leitor: textos de estética da recepção. LIMA, Luiz Costa (coord. e tradução). Rio de Janeiro: Paz e Terra, 1979.

KOSELLECK, Reinhardt. Futuro passado: contribuição à semântica dos tempos históricos. MAAS, Wilma Patrícia; PEREIRA, Carlos Almeida (trad.); BENJAMIN, César (revisão). Rio de Janeiro: Contraponto: Ed. PUC-Rio, 2006.

KRAAY, Hendrik, Política racial, Estado e forças armadas na época da Independência: Bahia, 1790-1850. São Paulo: Hucitec, 2011.

, “ 'Frio como a pedra de que se há de compor': caboclos e monumentos na comemoração da independência na Bahia, 1870-1900. In: Tempo (Niterói. Online) , v. 7, p. 51-81, 2003.

, "Entre o Brasil e a Bahia: as comemorações do Dois de Julho em Salvador, século XIX”. In: Afro-Ásia, v. 23, p. 49-87, 2000.

LABATUT, Pedro. Defeza do General Labatut, sobre a sua conducta em quanto commandou o exercito pacificador da Bahia, em resposta aos quatro artigos das accuzação, que lhe forão communicados por ordem do conselho de guerra; a quem tem já respondido por determinação de S.M.I. Rio de Janeiro: Typographia de Silva Porto e Companhia, 1824.

LACERDA, Rodrigo, “673 páginas, seis quilos e seiscentos gramas”. In: João Ubaldo RIBEIRO, Viva o povo brasileiro, edição especial de 30 anos. Rio de janeiro: Objetiva, 2014, p.7-14. 
LACOWICZ, Stanis David. Mitos hispânicos no romance brasileiro: uma leitura de $O$ Chalaça (1994) e de O feitiço da ilha do Pavão (1997). Dissertação de Mestrado. Faculdade de Ciências e Letras de Assis - UNESP, Assis, 2012.

LAFETÁ, João Luiz, 1930: a crítica e o modernismo. São Paulo: Duas Cidades, 1974.

LAJOLO, Marisa. Como e por que ler o romance brasileiro. São Paulo: Objetiva, 2004. LAJOLO, Marisa \& ZILBERMAN, Regina. A formação da leitura no Brasil. São Paulo: Ática, 1999.

LE GOFF, Jacques. História e Memória. FERREIRA, Irene; LEITÃO, Bernardo; BORGES, Suzana Ferreira (trad.); 5 edição. Campinas, SP: Editora da Unicamp, 2003.

LEDEZMA, Gerson Galo, "Religiosidade Cívica na Bahia: Comemorando o Primeiro Centenário da Independência a 2 de Julho de 1923”. Entre a memória nacional e a memória regional. Esboços: histórias em contextos globais, Florianópolis, v. 16, n. 21, p. 69-87, mar. 2009.

LIMA, Manuel de Oliveira. O movimento de independência,1821-1822. São Paulo: Melhoramentos, 1972.

. Dom João VI no Brasil. Rio de Janeiro: Topbooks, 1996. . Formação histórica da nacionalidade brasileira. $3^{\mathrm{a}}$ edição. Rio de Janeiro: Topbooks; São Paulo: Publifolha, 2000.

LYRA, Maria de Lourdes Viana. Memória da Independência: Marcos e Representações Simbólicas. Revista Brasileira de História. São Paulo, v. 15, n.29, 1995, p.173-206. A utopia do poderoso império. Portugal e Brasil: bastidores da política (1798-1822). Rio de Janeiro, Sette Letras, 1994

O nascimento da imprensa brasileira. Rio de Janeiro: Jorge Zahar, 2004

Dom Pedro I: um herói sem nenhum caráter. GASPARI, Elio; SCHWARCZ, Lilia M. (coordenação). São Paulo: Companhia das Letras, 2006.

MACHADO, André R.A.; GANDRA JR., Carlos A.C.; ZEN, Eric R.G.; SPÓSITO, Fernanda; CONSEGLIERE, Renata I. C., orientação: Prof.Dr.István Jancsó. Cronologia de História do Brasil Monárquico (1808-1889). São Paulo: Humanitas/ FFLCH/USP,2000.

LIMA, Luiz Costa, “A pouco cordial cordialidade”. In: Revista USP. São Paulo, n.110, p.107-114, julho/agosto/setembro 2016.

LOPES, Gabriella Assumpção da S. Santos \& SILVA, Marcela de Oliveira Santos. “ 'Heroínas Bahianas': Personagens femininas nas comemorações do centenário da 
Independência da Bahia. In: Democracias e ditaduras no mundo Contemporâneo. XII Encontro da Associação Nacional de História. Seção Mato Grosso do Sul. 13 a 16 de outubro de 2014, UFMS/ CPAQ, Aquidauana, MS.

LOUREIRO, Jayme Eduardo, “A formação de um enfant terrible: poetização e resistência em A idade do serrote". Tese de Doutorado. Faculdade de Filosofia, Letras e Ciências Humanas da Universidade de São Paulo, 2009

LUSTOSA, Isabel. Insultos impressos: a guerra dos jornalistas na Independência, 1821 1823. São Paulo: Companhia das Letras, 2000.

,D. Pedro I: um herói sem nenhum caráter. Elio GASPARI \& Lilia

M. SCHWARCZ (coord.). São Paulo: Companhia das Letras, 2006.

D. Pedro I: um herói sem nenhum caráter. Elio GASPARI \& Lilia

M. SCHWARCZ (coord.). São Paulo: Companhia das Letras, 2006.

LYRA, Maria Lourdes de Viana. "Memória da Independência: Marcos e Representações Simbólicas. Revista Brasileira de História, v.15, n.29. São Paulo, 1995.

MAGALHÃES JUNIOR, Raimundo. A arte do conto: sua história, seus gêneros, sua técnica, seus mestres. Rio de Janeiro: Edições Bloch, 1972.

MALATIAN, Teresa, Oliveira Lima e a construção da nacionalidade. São Paulo: Fapesp, Bauru: EDUSC, 2001.

MALERBA, Jurandir (org.). A Independência Brasileira - Novas Dimensões. Rio de Janeiro: Editora FGV,2006.

MARCÍLIO, Carla Crevelanti. Chiquinha Gonzaga e o Maxixe. Dissertação de mestrado apresentada ao Programa de Pós-Graduação em Música, do Instituto de Artes da Universidade Estadual Paulista "Júlio de Mesquita FilholUNESP. São Paulo, 2009, MARTINS, Nilce Sant'Anna. Introdução à estilística: A expressividade na língua portuguesa. São Paulo: EDUSP, 2008.

MATTOS, Cláudia Valadão de; OLIVEIRA, Cecília Helena de Salles (orgs.). O Brado do Ipiranga. São Paulo: EDUSP: Museu Paulista da Universidade de São Paulo, 1999. MATTOS, Ilmar Rohloff. O tempo saquarema. Rio de Janeiro: Access Editora, 1999. MAXWELL, Kenneth. "Conjuração mineira: novos aspectos. Revista Estudos Avançados, v.3, n.6, 1989.

MELCHIOR, Elísio de O. Visconde de Cairu, sua vida e sua obra. Rio de Janeiro: 1959. MELLO, Evaldo Cabral. A outra Independência: o federalismo pernambucano de 18171824. São Paulo: Ed. 34, 2004. 
Frei Joaquim do Amor Divino Caneca. São Paulo, Editora 34,

2001.

MERQUIOR, José Guilherme. "Gênero e estilo nas memórias póstumas de Brás Cubas". Colóquio/Letras, v.8, 1972, p.12-20.

MEYER, Marlyse. Folhetim: Uma história. São Paulo: Companhia das Letras, 1996. . Caminhos do imaginário no Brasil. São Paulo: Edusp, 2001.

MOTA, Carlos Guilherme. 1822: Dimensões. São Paulo: Perspectiva, 1986. Nordeste 1817: Estruturas e Argumentos. São Paulo: Perspectiva, 1972.

MOREL, Marco. Frei Caneca: entre Marília e a Pátria. Rio de Janeiro, FGV, 2000.

Obras diversas de F. A. P. M. P. — Niterói e Rio de Janeiro, 1840-1841, 2 vols.

NEVES, José Alberto Pinho. História do Brasil de Murilo Mendes: travessia para o conhecimento. Tese de doutotado. Programa de Pós-graduação em Educação da Universidade Federal de Juiz de Fora. Juiz de Fora, Minas Gerais, 2016.

NEVES, Lúcia B. P. Corcundas e Constitucionais. A cultura política da Independência (1820-1822). Rio de Janeiro: Revan, 2003.

. "Portugal durante a ausência do rei". In: Revista USP, São Paulo, n.79, p.10-21, setembro/novembro, 2008.

NORTON, Luiz NORTON, A corte de Portugal no Brasil: notas, alguns documentos diplomáticos e cartas da Imperatriz Leopoldina. Coleção Brasiliana. São Paulo: Companhia Editora Nacional, 1938.

NORA, Pierre. "Entre memória e história. A problemática dos lugares"; trad. KHOURY, Yara Aun. Projeto História, São Paulo, n.10, p.7-28, 1993.

NOVAIS, Fernando Antônio. Portugal e Brasil na crise do Antigo Sistema colonial (1777-1808). São Paulo: Hucitec, 2005.

COBERACKER JUNIOR, Carlos H. A Imperatriz Leopoldina: sua vida e sua época: ensaio de uma biografia. Rio de Janeiro: Conselho Federal de Cultura, 1973.

OLIVEIRA, Cecília Helena Lorenzini de Salles. O disfarce do anonimato: o debate político através dos folhetos (1820-1822). 1979. Dissertação de Mestrado em História. Faculdade de Filosofia, Letras e Ciências Humanas, Universidade de São Paulo. São Paulo.

OLIVIERI-GODET, Rita. Viva o povo brasileiro - A ficção de uma nação plural. São Paulo: É realizações, 2014. 
OLIVIERI-GODET, Rita e SOUZA, Lícia Soares de. Identidades e representações na Cultura Brasileira. João Pessoa: Ideia, 2001.

OTSUKA, Edu Teruki. "Espírito rixoso: para uma reinterpretação das Memórias de um sargento de Milícias”. In: Revista do Instituto de Estudos Brasileiros, São Paulo, n.44, p.105-124, fev.2007.

PACÍFICO, Elis, A construção de uma identidade nacional brasileira em visões estrangeiras (1808-1822). Dissertação de Mestrado. Faculdade de Filosofia, Letras e Ciências Humanas (USP). São Paulo, 2015.

PALMER, Robert. The Age of the Democratic Revolution: a Political History of Europe and America, 1760-1800. Princeton: Princeton University Press, 1959-1964.

PALTI, Elias José. El tiempo de la política. Lenguaje e historia en el siglo XIX. Buenos Aires: Siglo XXI, 2007.

La nación como problema. Los historiadores y la "cuestión nacional". Buenos Aires: Fondo de Cultura Económica, 2002.

PARRON, Tâmis Peixoto (org)., José de Alencar: Cartas a favor da escravidão. São Paulo: Hedra, 2008.

A política da escravidão na Era da liberdade: Estados Unidos,

Brasil e Cuba, 1787-1846. Tese de Doutorado. Faculdade de Filosofia, Letras e Ciências Humanas da Universidade de São Paulo. São Paulo, 2015.

PASQUAL, Camila Marcelina. O Chalaça, de José Roberto Torero: o romance e o diálogo com a tradição. Dissertação de Metrado apresentada ao Curso de Pós-Graduação em Letras- Literatura Brasileira e Teoria Literária da Universidade Federal de Santa Catarina. Florianópolis, junho de 2006.

PEDREIRA, Jorge Miguel Viana \& COSTA, Fernando Dores. D. João VI: um príncipe entre dois continentes. São Paulo: Companhia das Letras, 2008.

PENALVES, Antônio Rocha. A recolonização do Brasil pelas Cortes: história de uma invenção historiográfica. São Paulo: UNESP, 2009.

PEREIRA, Sara Marques PEREIRA, D. Carlota Joaquina - Rainha de Portugal, $2^{\text {a }}$ edição ampliada. Lisboa: Livros Horizonte, 2008.

PESAVENTO, Sandra Jatahy. "Fronteiras da ficção. Diálogos da história com a literatura". In: Revista de História das Ideias, v.21, Coimbra, 2000, p.33- 57.

PICCHIO, Luciana Stegagno, "Vida-poesia de Murilo Mendes". In: Murilo MENDES, Poesia completa e prosa, volume único. Luciana Stegagno PICCHIO (org. e preparação de texto). Rio de Janeiro: Nova Aguilar, 1994. 
PIMENTA, João Paulo; ATTI, César; CASTRO, Sheila Virginia; Dimambro, Nadiesda; LANNA, Beatriz Duarte; PUPO, Marina; VIEIRA, Luís Otávio. “A Independência e uma cultura de história no Brasil". Revista Almanack, Guarulhos, n.8, p.5-36, 2ºm.de 2014. PIMENTA, João Paulo. “A Independência do Brasil e o liberalismo português: um balanço da produção acadêmica".In: HIb: Revista de Historia Iberoamericana, v. 1", 2008 .

. "A independência do Brasil como uma revolução: história e atualidade de um tema clássico”. In: História da Historiografia, v. 3, p. 53-82, 2009.

. "De Raynal a De Pradt: apontamentos para um estudo da idéia de emancipação da América e sua leitura no Brasil”. Almanack Braziliense, [S.1.], n. 11, p. 88-99, may 2010.

Tempos e espaços das independências: a inserção do Brasil no mundo ocidental (c.1780-c.1830). Tese de livre docência defendida na Faculdade de Filosofia, Letras e Ciências Humanas da Universidade de São Paulo. São Paulo, 2012. . "Literatura e condição colonial na América portuguesa (século XVIII).” FRAGOSO, J. \& GOUVÊA, M. (orgs.) - O Brasil colonial: volume 3. Rio de Janeiro: Civilização Brasileira, 2014, p.595-634.

A independência do Brasil e a experiência hispano-americana (1808-1822). São Paulo: Hucitec : Fapesp, 2015.

PIMENTA, João Paulo; PAULINO, Mariana Ferraz, "Uma revolução interditada: Esboço de uma genealogia da ideia de "não-independência"do Brasil". In: ALTEZ, Rogelio y CHUST, Manuel (eds.), Las revoluciones en el Largo siglo XIX Latinoamericano. Madrid: AHILA: Iberoamericana: Vervuert, 2015.

PINHO, José Wanderley de A. "A guerra da independência (crônica de toda a campanha)". In: Revista do Instituto Histórico e Geográfico Brasileiro. Rio de Janeiro, volume 278, jan-mar. 1968, p. $35-86$

PINTO, Julio Pimentel. A leitura e seus lugares. São Paulo: Estação Liberdade, 2004.

PRADO JÚNIOR, Caio. Evolução política do Brasil: colônia e império. São Paulo: Brasiliense, 1988.

A Formação do Brasil Contemporâneo. São Paulo: Brasiliense, 2008.

PROENÇA, Manoel Cavalcanti (Org.). Literatura popular em verso - antologia. Belo Horizonte: Itatiaia; São Paulo: Edusp; Rio de Janeiro: Casa de Rui Barbosa, 1986. 
REGO, Enylton de Sá Rego, "Machado de Assis e a sátira menipéia: um diálogo com os textos de Luciano", Letterature d'America, n.4, 1983, p.15-38.

REZUTTI, Paulo. D. Pedro: a história não contada. São Paulo: Leya, 2015.

RIBEIRO, Gladys. S. A liberdade em construção: identidade nacional e conflitos antilusitanos no Primeiro Reinado. Rio de Janeiro: Relume \& Dumará: 2002.

RIBEIRO, Mariana dos Santos, "Frei Caneca e a Confederação do Equador”. In: Revista Intellèctus, v.5, n.2, 2006.

RIBEIRO, João Ubaldo. Setembro não tem sentido, $4^{\mathrm{a}}$ ed.Rio de Janeiro: Objetiva, 2012. RICOEUR, Paul. Tempo e Narrativa - Tomo I. CESAR, Constança Marcondes (tradução). Campinas: Papirus, 1994. . Tempo e narrativa - Tomo III. FERREIRA, Roberto Leal (trad.); VILLELA-PETIT, Maria da Penha (revisão técnica). Campinas, SP: Papirus, 1997. A memória, a história, o esquecimento. FRAÇOIS, Alain (trad.). Campinas, SP: Editora da Unicamp, 2007.

RIZZINI, Carlos. O livro, o jornal e a tipografia no Brasil (1500-1822). Rio de Janeiro: Kosmos, 1945.

ROCHA, João Cezar de Castro, Machado de Assis: Lido e relido. São Paulo: Ed. Unicamp: Alameda editorial, 2016.

RODRIGUES, José Honório. Independência: revolução e contra-revolução. São Paulo: Editora da Universidade de São Paulo, 1975.

RODRIGUES, Thamara de Oliveira. "A Revolução Pernambucana e as disputas historiográficas: Abreu e Lima e Francisco Adolfo de Varnhagen. In: Revista História e Cultura, volume 6, número 1. Franca, março. 2017, p. 289 - 309.

ROMERO, Silvio, História da literatura brasileira. Tomo II. Edição Comemoratva. Luiz Antonio BARRETO (org.). Rio de Janeiro: Imago Editora; Aracaju: Universidade Federal de Sergipe, 2011.

ROSA, Giorgio de Lacerda. A suprema causa motora: o providencialismo e a escrita da História no Brasil (1808-1825). Dissertação de Mestrado, Mariana: Universidade Federal de Ouro Preto, 2011.

RÜSEN, Jorn. História Viva. Teoria da História III: Formas e funções do conhecimento histórico. Brasília: Ed. da UNB, 2007.

Que es la cultura histórica?: Reflexiones sobre uma nueva manera de abordar la historia. Tradução: COSTA, F. Sánchez; SCHUMACHER, Ib, 1994. 
SALES, Germana Maria de Araújo. "Folhetins: uma prática de leitura no século XIX". In: Entrelaces - Revista do Programa de Pós-Graduação em Letras-Literatura Brasileira da Universidade Federal do Ceará, n.1. Fortaleza, agosto de 2007, p.44- 56.

SALIBA, Elias Thomé. As utopias românticas. São Paulo: Editora Brasiliense, 1991.

Raízes do riso. A representação humorística na história brasileira: da Belle Époque aos primeiros tempos do rádio. São Paulo: Companhia das Letras, 2002.

. "História cultural do humor: Balanço provisório e perspectivas de pesquisas". In: Revista de História, n.176, 2017, p.01-39.

SANTOS, Cristiane A. Camacho. Escrevendo a história do futuro: A leitura do passado no processo de Independência do Brasil; Dissertação de Mestrado. Faculdade de Filosofia, Letras e Ciências Humanas (USP). São Paulo, 2010.

SCHNAIDERMAN, Boris. "Tempo. Literatura. História. Algumas variações"; in: Revista Literatura e Sociedade. São Paulo, n.5, 2000, p.12-17.

SCHOLES, Robert. "Leitura: uma atividade intertextual". In: Protocolos de leitura. Rio de Janeiro: Edições 70, 1991. p.17-64.

SCHWARZ, Roberto. Um mestre na periferia do capitalismo: Machado de Assis. São Paulo: Livraria Duas Cidades, 1990.

SEBASTIÁN, Javier Fernández (dir.). Diccionário político y social del mundo iberoamericano. La era de las revoluciones, 1750-1850. (Iberconceptos I), Madrid: Fundación Carolina: Sociedad Estatal de Conmemoraciones Culturales: Centro de Estudios Políticos y Constitucionales, 2009.

SLEMIAN, Andréa; MARTINS, Ariane Cristina; PIMENTA, João Paulo Garrido; WISIAK, Thomas, orientação: Prof. Dr. István Jancsó, Cronologia de História do Brasil Colonial (1500-1831). São Paulo: FFLCH/USP,1994.

SEVCENKO, Nicolau. Literatura como missão: tensões sociais e criação cultural na Primeira República. São Paulo: Companhia das Letras, 2003.

SILVA, Bruno Diniz. Da restauração à regeneração: linguagens políticas em José da Silva Lisboa. Dissertação de Mestrado, Mariana, Universidade Federal de Ouro Preto, 2010.

SILVA, Francisco Gomes da. Memorias offerecidas á nação brasileira. Pelo Conselheiro Francisco Gomes da Silva. Londres: Impresso por L.Thompson, 19, Great St.Helens, 1831. 
SILVA, Raymundo José da. Identidades e representações do Nordeste na Literatura de Cordel. Dissertação de Mestrado. Universidade Federal de Mato Grosso do Sul. Três Lagoas: Campus de Três Lagoas, 2008.

SODRÉ, Nelson Werneck. As razões da independência. Rio de Janeiro: Civilização Brasileira, 1969.

SOUZA, Adriana Barreto de. Duque de Caxias: o homem por trás do monumento. Rio de Janeiro, Civilização Brasileira, 2008.

. "Experiência, configuração e ação política: uma reflexão sobre as trajetórias do duque de Caxias e do general Osório". In: TOPOI, v.10, n. 19, jul.-dez.2009, p. $90-111$.

SOUSA, Octávio Tarquínio de, Vida de D. Pedro I, 3 vol. Belo Horizonte: Itatiaia, 1988; SOUZA, Bernardino José de, Heroínas Bahianas: Joanna Angélica, Maria Quitéria, Anna Nery. Rio de Janeiro: Paralelo; Brasília: Instituto Nacional do Livro, 1972.

SOUZA, Valmir de. Murilo Mendes: da história satírica à memória contemplativa. Tese de doutorado do curso de pós-graduação do Departamento de teoria Literária e Literatura Comparada da Universidade de São Paulo. São Paulo, 2006

SUSSEKIND, Flora. Cinematógrapho de letras: literatura, técnica e modernização do Brasil. São Paulo: Companhia das Letras, 1987. O Brasil não é longe daqui: o narrador, a viagem. São Paulo: Companhia das Letras, 1990. . Papéis Colados. Rio de Janeiro: Editora UFRJ, 1993. Literatura e vida literária: polêmicas, diários \& retratos. $2^{\mathrm{a}}$ ed. Revista. Belo Horizonte: Editora UFMG, 2004.

TAUNAY, Afonso Escragnolle de, A Missão Artística de 1816. Brasília: Editora Universidade de Brasília, 1983.

TAVARES, Francisco Muniz. História da revolução de Pernambuco em 1817. Recife: Imprensa industrial, 1917.

TEIXEIRA, Ivan (org.), Épicos: Prosopopéia: O Uraguai: Caramuru: Vila Rica: A Confederação dos Tamoios: I-Juca-Pirama. São Paulo: EDUSP: Imprensa Oficial do Estado de São Paulo, 2008.

TINHORÃO, José Ramos. "O maxixe”. In: Pequena história da música popular brasileira (da modinha à canção de protesto), $3^{\mathrm{a}}$ ed. Petrópolis: Vozes, 1978, p.51-83. Os romances em folhetim no Brasil: 1830 à atualidade. São Paulo: Duas Cidades, 1994. 
TERNAVASIO, Marcela, Candidata a la corona. La infanta Carlota Joaquina en el laberinto de las revoluciones hispanoamericanas. Buenos Aires: Siglo XXI, 2015.

THOMPSON, E. P. Costumes em comum. Estudos sobre a cultura popular tradicional. São Paulo: Cia. das Letras, 1998.

TREVISAN, Anderson Ricardo, "Debret e a Missão Artística Francesa de 1816: aspectos da constituição da arte acadêmica no Brasil.’In: Plural, v.14, p. 9-32, Dez/2007.

VARNHAGEN, Francisdo de Adolfo, História Geral do Brasil antes de sua separação e independência de Portugal. Tomo I e II. Rio Janeiro: Casa e E. \& H.Laemmert, 1854.

História da independência do Brasil. Rio de Janeiro: Instituto Histórico e Geográfico Brasileiro, 1916.

VELOSO, Mariza; MADEIRA, Angélica. Leituras brasileiras - itinerários no pensamento social e na literatura. São Paulo: Paz e Terra, 1999. VERÍSSIMO, José. História da literatura brasileira. Rio de Janeiro: José Olímpio, 1954. WEELING, Arno (coord.). Origens do Instituto Histórico e Geográfico Brasileiro: ideias filosóficas e sociais e estruturas de poder no Segundo Reinado. Rio de Janeiro: IHGB, 1989.

WHITE, Hayden. Trópicos do discurso: Ensaios sobre a crítica da Cultura. FRANCA NETO, Alípio Correia de (trad.); $2^{a}$ ed. São Paulo: Editora da Universidade de São Paulo, 2001.

- Meta-História: A Imaginação Histórica do Século XIX. MELO, José Laurênio de. $2^{\mathrm{a}}$ ed. São Paulo, Editora da Universidade de São Paulo, 2008.

El contenido de la forma: narrativa, discurso y representación histórica. Barcelona: Paidós, 1992.

ZÍCARI, Julián. "Narrativa literária e historia, algunos puntos de debate: la concepción metahistórica de Hayden White frente a las críticas de Chris Lorenz". Revista História da historiografia, n.18. Ouro Preto, agosto de 2015, p.127-139.

WILLIAMS, Raymond. Marxismo y literatura. Barcelona, Península, 1980.

WISIAK, Thomas, "Itinerário da Bahia na Independência do Brasil (1821-1823)". In: István JANCSÓ (org.) Independência: História e historiografia. São Paulo: Fapesp: Hucitec, 2005, 447-474.

WISNIK, José Miguel. “Machado maxixe: o caso Pestana”. In: Teresa, n.4-5, p.13-79, 2003. 